Florida International University FIU Digital Commons

11-15-2017

\title{
Reading Spaces: Nation and Popular Learning in Nineteenth-Century Lima
}

Gracia G. Solis

Florida International University College of Law, gsoli002@fiu.edu

DOI: 10.25148 /etd.FIDC004042

Follow this and additional works at: https://digitalcommons.fiu.edu/etd

Part of the History Commons

\section{Recommended Citation}

Solis, Gracia G., "Reading Spaces: Nation and Popular Learning in Nineteenth-Century Lima" (2017). FIU Electronic Theses and Dissertations. 3521.

https://digitalcommons.fiu.edu/etd/3521

This work is brought to you for free and open access by the University Graduate School at FIU Digital Commons. It has been accepted for inclusion in FIU Electronic Theses and Dissertations by an authorized administrator of FIU Digital Commons. For more information, please contact dcc@fiu.edu. 


\title{
FLORIDA INTERNATIONAL UNIVERSITY
}

Miami, Florida

\section{READING SPACES: NATION AND POPULAR LEARNING IN NINETEENTH-CENTURY LIMA}

\author{
A dissertation submitted in partial fulfillment of the \\ requirements for the degree of \\ DOCTOR OF PHILOSOPHY \\ in \\ HISTORY \\ by
}

Gracia Solis

2017 
To: Dean John F. Stack, Jr.

Steven J. Green School of International and Public Affairs

This dissertation, written by Gracia Solis, and entitled Reading Spaces: Nation and Popular Learning in Nineteenth-Century Lima, having been approved in respect to style and intellectual content, is referred to you for judgment.

We have read this dissertation and recommend that it be approved.

Leonardo Ferreira

\begin{tabular}{c}
\hline \\
$\frac{\text { Burora Morcillo }}{\text { Bianca Premo, Co-Major Professor }}$ \\
\hline Victor Uribe-Uran, Co-Major Professor
\end{tabular}

Date of Defense: November 15, 2017

The dissertation of Gracia Solis is approved.

Dean John F. Stack, Jr.

Steven J. Green School of International and Public Affairs

Andrés G. Gil

Vice President for Research and Economic Development and Dean of the University Graduate School

Florida International University, 2017 
(C) Copyright 2017 by Gracia Solis

All rights reserved. 


\section{DEDICATION}

I dedicate this dissertation to my parents, Maria Peña Chavez and Carlos Solis, whose unwavering belief in education continues to inspire me. 


\section{ABSTRACT OF THE DISSERTATION \\ READING SPACES: NATION AND POPULAR LEARNING IN NINETEENTH- CENTURY LIMA}

by

Gracia Solis

Florida International University, 2017

Miami, Florida

\section{Professor Bianca Premo, Co-Major Professor \\ Professor Victor Uribe, Co-Major Professor}

My dissertation examined the transformation of reading practices and ideas about the functions of alphabetic literacy in nineteenth-century Lima. Scholars of Latin America have attributed improvements in literacy rates to the rise of the Teaching State in the twentieth century; however, as I showed, literacy and reading culture spread decades earlier in the Peruvian capital, at a time when the state lacked the stability and resources to develop a public system of education. "Reading Spaces" argued that during the second half of the nineteenth century, private educational enterprise from a diverse group of booksellers, writers, and educators established key institutions of the modern Teaching State, including a national textbook industry as well as pedagogical newspapers, associations, and conferences. They did so in a process that promoted new pedagogical methods and helped spread alphabetic literacy and reading practices.

Developments in the disciplines of book history, the cultural history of education, and the history of reading informed my methodological approach to a variety of previously unexamined sources including books, textbooks, pedagogical periodicals, as 
well as bookstore organ newspapers and catalogues. Both the intellectual content and paratext of published sources provided a wealth of information regarding the circulation of the texts, their reception among state authorities and influential members of Lima's society, and the relationship of book and textbook authors to their publishers and readers. My dissertation revealed that textbook standardization and the proliferation of pedagogical newspapers were processes firmly rooted in the development of Peru's private educational enterprise, publishing industry and educational legislation of the nineteenth century. These processes expanded Lima's public sphere, where booksellers, editors, writers, and teachers debated modern pedagogies and promoted broad engagement in educational matters. They conducted pedagogical conferences, intellectual competitions, national expositions and reorganized civic festivities. The presence of a pedagogical public sphere, which directed the course of institutions of the modern nation state in Peru, encourages a reassessment of our traditional narratives of the relationship between education and nation in Latin America and beyond. 


\section{TABLE OF CONTENTS}

CHAPTER

PAGE

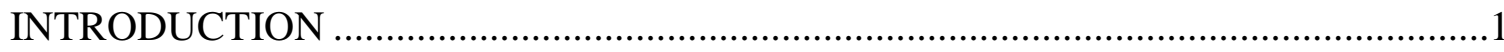

CHAPTER I. Alphabetic Literacy and Reading Culture from Colonial to Early Republican Lima.

CHAPTER II. For Erudition Only: Lima’s Public Library, 1821-1912 .66

CHAPTER III. Beyond European Literature: Bookstores and the National Textbook and Book Industry, 1850-1900

CHAPTER IV. Legitimizing Text and Method in Lima's Public Sphere of Pedagogical Society

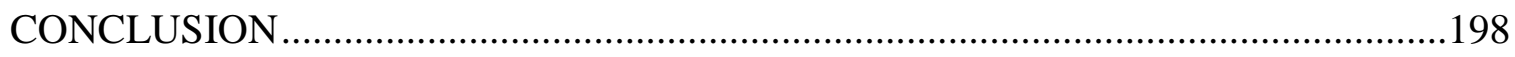

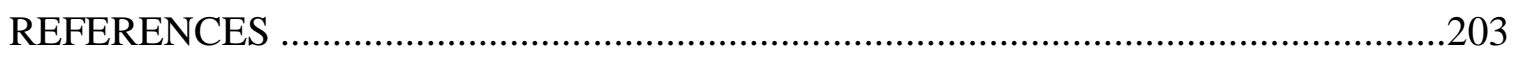

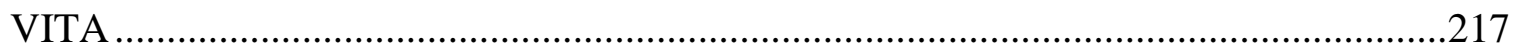




\section{LIST OF TABLES}

TABLE

PAGE

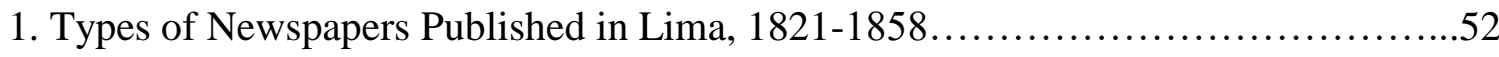

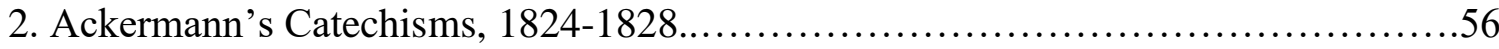

3. Library Users at the National Library and Books Borrowed from 1884 to $1911 \ldots . .102$

4. Books Borrowed by Subject at Lima's National Library in $1893 \ldots \ldots \ldots \ldots \ldots \ldots \ldots . \ldots 107$

5. Books Borrowed by Subject at Lima's National Library in $1894 \ldots \ldots \ldots \ldots \ldots \ldots \ldots . . . \ldots 108$

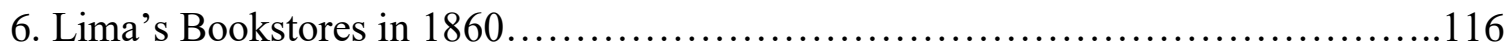

7. Political Catechisms and Textbooks Published during the Nineteenth Century........135

8. History Books Published during the Nineteenth Century........................139

9. Geography Books Published during the Nineteenth Century......................142

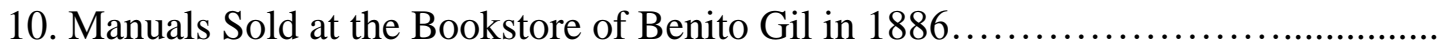




\section{LIST OF FIGURES}

FIGURE

PAGE

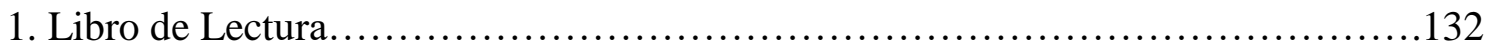

2. Nuevo Manual de la Cocina Peruana por un Limeño Mazamorrero...................154

3. Palacio de Bellas Artes en la Exposición de Filadelfia .............................167

4. Palacio de Maquinaria en la Exposición de Filadelfia..............................168

5. Colegio Nacional de Señoritas..............................................170 


\section{INTRODUCTION}

With novels and storybooks, a very different thing happens; young people and children devour these books by the thousands.

—Joaquín Capelo, Sociología de Lima, 1902

No one, no matter how poor, stops short of buying or borrowing a book.

Thus, against the prevailing positivist view, it is evident that people in Lima read.

—Jorge Miota, El Comercio (Lima), 1904.

Only a minority of Lima's residents had the ability to read printed or handwritten text during the period of Spanish colonial rule. ${ }^{1}$ The remarks of Peruvian sociologist Joaquín Capelo and writer Joaquín Miota point to the ubiquity of reading practices in Lima less than a century after Peru gained political independence from Spain. A 1908 census later confirmed that approximately 80 percent of the population in the Peruvian capital could read. ${ }^{2}$ This dissertation explores the implications of this literacy revolution, and particularly argues that during the second half of the nineteenth century, private educational enterprise from a diverse group of booksellers, writers, and educators established key institutions of the modern Estado Docente or "Teaching State," including a national textbook industry as well as pedagogical newspapers, associations, and

\footnotetext{
${ }^{1}$ See Pablo Macera, "Noticias sobre la enseñanza elemental en el Perú durante el coloniaje," in Trabajos de historia, vol. II (Lima: Instituto Nacional de Cultura, 1977), 258 and Cristóbal Aljovín de Losada, Caudillos y constituciones (Perú, 1821-1845 (Lima: Instituto Riva-Agüero, Fondo de Cultura Económica, 2000). Both works and figures are discussed in José Ragas, "Leer, escribir, votar. Literacidad y cultura política en el Perú (1810-1900)," Histórica 31 (2007): 107-134.),” 115.

${ }^{2}$ Censo de la provincia de Lima (Lima: Impr. De “La Opinión Nacional, 1915), 102.
} 
conferences. ${ }^{3}$ They did so in a process that promoted new pedagogical methods and helped spread alphabetic literacy and reading practices.

Scholars of Latin America have generally attributed improvements in literacy rates to the twentieth-century rise of the Teaching State-defined as a centralized institutional framework constructed by national and local governments to provide educational services and promote homogenous curricular content. ${ }^{4}$ However, the spread of literacy and reading practices in Lima during the previous century, at a time when the Peruvian state lacked the stability and often, the resources to develop a public system of education, challenges this view. To better understand this process, "Reading Spaces" focuses on changes in reading practices from the late colonial period through the nineteenth century, exploring the role of civil society and its interaction with the Peruvian state as well as that of readers in transforming Lima's book market and ideas about reading.

\section{Historical Questions}

To analyze the processes that impacted the spread of literacy and reading practices in Lima over the course of the nineteenth century, as well as the significance of

\footnotetext{
${ }^{3}$ The term was originally coined by Carlos Newland, see "The Estado Docente and Its Expansion: Spanish American Elementary Education, 1900-1950," Journal of Latin American Studies, Vol. 26, No. 2 (May, 1994): 449.

${ }^{4}$ See Carlos Newland, "The Estado Docente and Its Expansion" and Hillel D. Soifer, "Elite Preferences, Administrative Institutions, and Educational Development during Peru's Aristocratic Republic (18951919)" in State and Nation Making in Latin America and Spain: Republics of the Possible ed. Miguel A. Centeno and Agustin E. Ferraro (Cambridge University Press, 2013), 261-267. On the definition of the Estado Docente, also see Antonio Espinoza's definition in Education and the State in Modern Peru: Primary Schooling in Lima, 1821 -c. 1921 (Lima: Palgrave Macmillan, 2013), 159.
} 
this changing cultural context, the following questions guided my research: What educational ideas and institutions_- private or public, formal and informal—operated in the Peruvian capital? What, when, and where did people read? How did new reading practices support or challenge longstanding colonial values and ideas, particularly around the functions of reading? How did the expanded reading public of the end of the nineteenth century interact with the Peruvian state? To address these questions, the following chapters enter the physical spaces where nineteenth-century limeños obtained their reading materials, from the early bookstores and republican schools that offered imported European literature, to the national library with its less populated reading hall, to the bookstore-publishing houses where owners spearheaded efforts to create a national book and textbook industry, to the various public venues where both the state and private actors sought to legitimize and homogenize reading material.

\section{Sources}

The sources used in this study range broadly from administrative documents, pedagogical treatises, and educational legislation produced by government bureaucrats, to published books, textbooks, city directories, bookstore catalogues and organ newspapers, to pedagogical periodicals, and pamphlets from teacher associations. Many of these sources posed significant problems for writing about the experiences of readers. Library patrons, for instance, left few traces of their reading preferences. In the surviving institutional documents of Peru's national library, administrators rarely mentioned their 
patrons..$^{5}$ My approach, therefore, involved asking what institutional sources said and omitted about everyday library operations, and what were the implications of such operations for library users. ${ }^{6}$

Understanding the significance or influence of ideas within nineteenth-century published books, textbooks, and other reading materials involves discerning their circulation and reception, which can similarly pose a challenge to the historian. Government documents, particularly from the first half of the century, omitted information about textbook use in schools. Historical archives rarely have the impressions of readers of popular books and textbooks. For these types of materials, it was useful to analyze, in addition to the intellectual content, the paratext or the devices and conventions (including the title, author's name, preface, illustrations) that surround the main text of a literary work and mediate content to readers. ${ }^{7}$ The paratext of the published sources discussed in the following chapters provided a wealth of information regarding the circulation of the texts, their reception among state authorities and influential members of Lima's society, and the relationship of book and textbook authors to their publishers and readers.

\footnotetext{
${ }^{5}$ These documents can be found in Legajos 69-71, Biblioteca Nacional 1825-1909, Instrucción, Ministerio de Justicia, Culto, Beneficencia e Instrucción (RJ), Archivo General de la Nación (AGN), Lima, Perú.

${ }^{6}$ For an overview of the concept of "everyday life" in historical inquiry, see Andreas Eckert and Adam Jones, "Historical Writing about Everyday Life" in Journal of African Cultural Studies, Vol. 15, No. 1, Everyday Life in Colonial Africa (Jun., 2002): 5-16.

${ }^{7}$ Gerard Genette, Paratexts: Threshholds of Interpretation (Cambridge University Press, 1997), 1-4. Also see Leslie Howsam, "What is the Historiography of Books? Recent Studies in Authorship, Publishing, and Reading in Modern Britain and North America," The Historical Journal, Vol. 51, No. 4 (Dec., 2008), 1091.
} 
Traditional and New Histories of Education

Much of the scholarship on the history of education in Peru focuses on formal institutions, state legislation, and politicians and intellectuals behind educational reform. ${ }^{8}$ This scholarship reproduces the tropes of patriotic history (historia patria), representing the past from the vantage point of national leaders who sought to reform education, but faced incompetence and stiff challenges from rural elites, municipal authorities and political officers who were against educational reform. ${ }^{9}$ The exclusive use of administrative and official documents from the central government in Lima has produced these one-sided explanations, which disregard broader social, economic and cultural factors that affected educational processes.

Even recent contributions to volumes that use elaborate sociopolitical models of state and nation formation have distorted important components of the history of education by using a set of sources that only represent the views of historical actors within the central government. Hillel D. Soifer, for instance, examined a 1902 Peruvian census and official administrative documents to study Peruvian education between 1895 and 1919. As part of his argument regarding the emergence of the centralized Teaching State in the early twentieth century, he contended that "textbook standardization began in earnest under the first José Pardo administration" (1904-1908) and presented the short-

\footnotetext{
${ }^{8}$ See for example Carlos Daniel Valcárcel, Breve historia de la educación peruana (Lima: Editorial Educación, 1975) and Margarita Guerra and Lourdes Leiva Viacava, Historia de la educación peruana en la República, 1821-1876 (Lima: Biblioteca Nacional del Perú—Universidad Femenina del Sagrado Corazón, 2001).

${ }^{9}$ For a detailed discussion of this scholarship, see Antonio Espinoza, Education and the State in Modern Peru: Primary Schooling in Lima, 1821 -c. 1921 (Lima: Palgrave Macmillan, 2013), 4-9.
} 
lived pedagogical newspaper La Educación Nacional as a novelty. ${ }^{10}$ My dissertation demonstrates that textbook standardization and the proliferation of pedagogical newspapers - both essential components to the rise of the twentieth-century Teaching State-were processes firmly rooted in the development of Peru's private educational enterprise, publishing industry and educational legislation of the previous century. Other works with a similar state-centered approach also omit attention to the broader set of private actors who laid the foundations of the Teaching State in Peru. ${ }^{11}$

My approach takes intellectual inspiration from the "new" cultural history of education developed in recent decades. Scholars in this field conceptualize the history of education more broadly, considering the learning and disciplining that takes place outside as well as inside the classroom. They have also renovated approaches to educational institutions by taking as objects of study a wide range of subjects related to education including the organization of space and time, school curricula, methods, materials, and manuals used in the classroom. ${ }^{12}$ At issue is understanding the ways that the organization of school life, discipline, and interior regimen of educational establishments relate to broader educational, social and cultural values. These studies also seek to illustrate how

\footnotetext{
${ }^{10}$ Soifer, "Elite Preferences, Administrative Institutions, and Educational Development during Peru's Aristocratic Republic (1895-1919)," 262.

${ }^{11}$ See Eve-Marie Fell, "La Construcción de la Sociedad Peruana: Estado y Educación en el siglo XX, in Antonio Annino et al., eds., América Latina Dallo Stato Coloniale allo Stato Nazione (Milan: Franco Angeli Libri, 1987), 808-821 and Carlos Contreras, Maestros, Mistis y Campesinos en el Perú rural del siglo XX (Lima : EEP, 1996), 5.

${ }^{12}$ Various scholars ranging from Jurgen Habermas to Michel Foucault, Jacques Derrida and Roger Chartier have influenced a turn toward a cultural history of education. See António Nóvoa, "Texts, Images, and Memories: Writing "New" Histories of Education" in Cultural History of Education, ed. Thomas S. Popkewitz et. al. (New York, Routledge, 2001), 46-50.
} 
pedagogical compositions inform quotidian activities in institutions and beyond, and how legislation affects school regulations, as well as the attitudes and mentalities of students, teachers, and families. ${ }^{13}$

"Reading Spaces" is especially informed by the work of Peruvian historian Antonio Espinoza, who has combined traditional and cultural approaches to the history of education and the formation of the state in Peru. In his recent monograph, Education and the State in Modern Peru, Espinoza drew from recent trends in Latin American historiography, which have established the dynamic social and cultural components of state and nation formation as well as the important "interactions between state and civil society," to address educational processes in nineteenth-century Peru. He studied official educational ideas and policies, but also school culture and local responses to state intervention. He drew information from a broad set of sources from central and local governments, newspapers, memoirs, and textbooks. ${ }^{14}$ While Espinoza certainly found broad discord over educational content and teaching methods, he also established that schools expanded by the combined effect of "governmental intervention and social demand for education." ${ }^{.15} \mathrm{He}$ argues that the decentralized network of municipal schools that proliferated over the course of the nineteenth century, provided a framework for the centralized system of public schools of the twentieth century. ${ }^{16}$ My dissertation

\footnotetext{
${ }^{13}$ Alejandro Tiana Ferrer, "La Historia de la Educación en la actualidad: viejos y nuevos campos de estudio." In Repensar la historia de la educación: nuevos desafíos, nuevas propuestas, edited by Manuel Ferraz Lorenzo, 105-145. Madrid: Biblioteca Nueva, 2005.

${ }^{14}$ Antonio Espinoza, Education and the State in Modern Peru: Primary Schooling in Lima, 1821 -c. 1921 (Lima: Palgrave Macmillan, 2013), 2.

${ }^{15}$ Ibid, 3.

${ }^{16}$ Ibid, 6-7.
} 
complements Espinoza's work by unearthing the additional buried pillars of Peru's Teaching State, the dispersed efforts of booksellers, writers, and teachers in forming a national textbook industry, and establishing pedagogical newspapers, associations, and conferences. Moreover, it addresses the relationship of these processes to Lima's changing literacy rates and reading practices, subjects left out of Espinoza’s work.

My examination of literacy in nineteenth-century Lima is informed by scholarship on the related field of the history of reading. Addressing alphabetic literacy in nineteenthcentury Peru or Latin America — with only sporadic population census data, a major source of information about literacy — poses significant challenges for historians. This has forced several scholars to also examine indirect indicators of literacy such as school attendance, and the production and dissemination of printed media. ${ }^{17}$ In his now classical study of the role of print in Spanish-American revolutions, François Xavier Guerra asked whether it was possible to correlate school attendance or schooling (escolarización) with literacy rates (alfabetización). ${ }^{18}$ He suggested that a significant concentration of schools combined with a strong presence of printed materials — especially newspapers, pasquinades, proclamations and other texts addressing a diverse, and even popular public - show a society in the process of attaining high literacy and school attendance rates. ${ }^{19}$ Some scholars have suggested that rather than a lack of access to schools, it was the lack of access to reading

\footnotetext{
${ }^{17}$ François Xavier Guerra, Modernidad e independencias: ensayos sobre las revoluciones hispánicas, (Madrid: Ediciones Encuentro, S.A., [1992] 2009) and José Ragas, "Leer, escribir, votar. Literacidad y cultura política en el Perú (1810-1900),” Histórica 31 (2007): 107-134.

${ }^{18}$ François Xavier Guerra, Modernidad e independencias, 343-44.

${ }^{19}$ Ibid, 346.
} 
materials that kept literacy rates low during the colonial period. ${ }^{20} \mathrm{My}$ dissertation similarly takes the presence of an increased number of establishments that offered reading materials and the materials themselves, especially those that targeted diverse groups, as a reflection of climbing literacy rates, but also assumes the expansion of print culture operated as a stimulus for more people to learn how to read.

William Acree's concept of "everyday reading," which also builds on recent trends in cultural history, is a key term in the following chapters. The concept itself is a more nuanced way of thinking about print culture or the connections between reading and writing practices and social behaviors, individual and collective identities, economic transactions, politics, institutions, and ideologies. ${ }^{21}$ Influenced by James Scott's “everyday resistance" and Gilbert Joseph's and Daniel Nugent's edited volume on "everyday forms of state-formation," Acree developed the concept of everyday reading to underscore the relevance of reading (conceived as the process of interpreting and creating meaning out of text, images and objects) as both ordinary and extraordinary experiences in nineteenth-century Uruguay and Argentina. ${ }^{22}$ Acree emphasizes the pervasiveness of

\footnotetext{
${ }^{20}$ See Eugenia Roldán Vera, "Reading Questions and Answers: The Catechism as an Educational Genre in Early Independent Spanish America," Book History, Vol. 4 (2001), 22; Pilar Gonzalbo Aizpuru, "Leer de la infancia a la vejez," 47; Dorothy Tanck de Estrada, "La enseñanza de la lectura y de la escritura en la Nueva España, 1700-1821" in Independencia y educación (Colegio de México, 2013), 25. José Ragas made a similar suggestion in his study of literacy and political culture in Lima, noting that the overwhelming availability of print during the nineteenth century could have easily incentivized people to learn how to read, see “"Leer, escribir, votar. Literacidad y cultura política en el Perú (1810-1900)," 120.

${ }^{21}$ William Acree, Everyday Reading: Print Culture and Collective Identity in the Río de la Plata, 17801910 (Nashville: Vanderbilt University Press, 2011), 3.

${ }^{22}$ Ibid, 4. Also see James Scott, Weapons of the Weak: Everyday Forms of Peasant Resistance in South East Asia (London: Frank Cass, 1986) and Gilbert M. Joseph and Daniel Nugent, Everyday Forms of State Formation: Revolution and the Negotiation of Rule in Modern Mexico (Durham and London: Duke University Press, 1994).
} 
reading quotidian materials such as newspapers, magazines, popular gauchesque literature, postcards, matchboxes, tobacco related paraphernalia, coins, paper money, books, textbooks, photographs, catechisms and other objects, which shape collective identities, from nationalism to ideas of gender. The spread of literacy and ordinary reading practices in the nineteenth century brought people together more often than before and in greater numbers. The author described people associating with each other "because of reading" as "reading became the centerpiece of sociability." ${ }^{23}$ These practices helped shape group identities that "inspired behaviors, attitudes and values that ranged from waging war to educating future citizens. ${ }^{24}$

Although Acree often refers to the uniqueness of reading practices in the Río de la Plata region, the concept of everyday reading was useful in defining the parameters of my dissertation, which similarly examines ordinary reading materials that became broadly and more cheaply available over the course of the nineteenth century. New civics, geography and history textbooks with content about Peruvian landscapes and topography, legislation, and examples of national heroes replaced earlier translated European books with their foreign narrations, illustrations, and motifs, a process that began to outline the modern contours of a Peruvian national identity. The authors of these textbooks were often school teachers who used them in their own classrooms, but the paratext in the first pages (reviews, official endorsements, dedications, opening information, forewords)

\footnotetext{
${ }^{23}$ Ibid. Acree's emphasis.

${ }^{24}$ Ibid, 6-7.
} 
commonly addressed a wider audience. ${ }^{25}$ Acree also argues that everyday reading practices produced "unintended consequences," which celebrated certain traditions and modes of behavior, but also stirred animosity between political parties. In Lima, textbooks expressed a more homogenous idea of the nation, but they competed with an emergent popular book market where some literature reified a regional, coastal and uniquely "criollo" identity that essentialized differences between the urban and Europeanized population, on the one hand, and the highland, mostly Indian population on the other.

Theoretical Considerations

Before moving on to a detailed description of chapters, a brief explanation of the use of Jürgen Habermas's concept of the "public sphere" in this dissertation is appropriate. In the classical formulation, Habermas used the concept of "public sphere" to describe the development of an autonomous realm within civil society where private people conduct reasonable and critical debate over governing issues. ${ }^{26}$ Both an abstract model and a historical process, Habermas placed the maturity of the public sphere in eighteenth-century Europe, where critical debate flourished in newspapers and other

\footnotetext{
${ }^{25}$ Gerard Genette, Paratexts: Threshholds of Interpretation (Cambridge University Press, 1997), 1-4. Also see Leslie Howsam, "What is the Historiography of Books? Recent Studies in Authorship, Publishing, and Reading in Modern Britain and North America," The Historical Journal, Vol. 51, No. 4 (Dec., 2008), 1091.

${ }^{26}$ Jürgen, Habermas, The Structural Transformation of the Public Sphere: An Inquiry into a Category of Bourgeois Society (The MIT Press, 1991), 27. See also, Geoff Eley, "Nations, Publics, and Political Cultures: Placing Habermas in the Nineteenth Century," in Habermas and the Public Sphere, ed. Craig Calhoun (The MIT Press, 1992), 289-339.
} 
printed media as well as in new spaces of sociability such as cafes and salons. Since its publication, historians of Latin America have built on the concept to explore the history of civil society in relation to democracy in the region during the nineteenth century. ${ }^{27}$ The public sphere in these studies emerges as a space that enabled "communicative practice" among participants in democratic life - understood in Tocquevillian terms as participation in social, economic, and political associative practices - and the mediation of "economic processes and decision-making.", 28

This dissertation describes the flourishing of Lima's "public sphere" particularly around the associative activities of nineteenth-century booksellers, editors, educators, and writers, a group that can collectively be referred to as pedagogical society. Although education had long been the subject of debate in literary clubs and occasionally appeared discussed in the capital's newspapers, the expansion of Peru's publishing industry contributed to unprecedented communication and action around educational matters among a more diverse group of "enthusiasts of education." 29 Debates over the merit of new pedagogical methods, textbooks, school furniture, and the education of women

\footnotetext{
${ }^{27}$ Pablo Piccato, "Public sphere in Latin America: a map of the historiography," Social History, Vol. 35, No. 2 (2010): 165-192. Also see Carlos Forment, Democracy in Latin America (The University of Chicago Press, 2003) and Hilda Sabato, The Many and the Few: Political Participation in Republican Buenos Aires (Stanford, 2001).

${ }^{28}$ Picatto, "Public sphere in Latin America," 182-3.

${ }^{29}$ See for example "Congreso sesión del dia 10 de septiembre," Mercurio Peruano, September 12, 1827; "Congreso sesión del 1 de octubre," Mercurio Peruano, October 3, 1827 and "Educación Observaciones sobre la enseñanza científica y sobre el régimen de los colegios," Mercurio Peruano, May 14, 1828. The subject of education was often discussed in Juana Manuela Gorriti's literary gatherings, see for example Abel Delgado, "Educación del niño"; Mercedes Eléspuru y Lazo,"La instrucción de la muger." and Teresa González de Fanning, "Trabajo para la muger" in Veladas Literarias de Lima, 1876-1877, ed. Juana Manuela Gorriti (Buenos Aires: Imprenta Europea, 1892).
} 
appeared in the pages of pedagogical newspapers such as La Instrucción (1889-1891) and La Escuela Peruana (1892-1911) as well as in Lima's oldest surviving daily El Comercio. ${ }^{30}$ The same periodicals, as well as the organ newspapers of bookstorepublishing houses communicated the endeavors of individuals involved in private as well as public educational enterprise. ${ }^{31}$ Through the organization of new educational and cultural practices, including conferences, textbook contests, and intellectual competitions, they evaluated various aspects of national education and school culture in Peru. Members of literary and educational associations discussed pedagogical matters with each other, but they also announced their use of modern pedagogical methods and textbooks in promotional school pamphlets that reached families and parents. ${ }^{32}$ Beyond seeking more students and state support for their private educational endeavors, many of these individuals sought to shape the contours of Peruvian education by advocating for a centralized system of education that could promote homogenous methods, curricula, and content. They specifically wanted to see the adoption of modern pedagogical methods and national content in school textbooks.

Women figure as central actors within Lima's pedagogical public sphere. They were involved at all levels in the expansion of critical debates over education and in some

\footnotetext{
${ }^{30}$ El Comercio, for instance, published Teresa González de Fanning's series of articles on education, later compiled in Educación Femenina (Lima: Tipografía de "El Lucero," 1905). The title of the compilation is probably more telling of women writers' need to write under the guise of certain subjects since the articles focused more closely on defending the secularization of Peruvian education. Also see "Libros de texto" in La Escuela Peruana, June 1, 1895 and "Nuestro Proposito," La Instrucción (Lima), November 10, 1889.

${ }^{31}$ Ateneo de Lima, Certamen de Textos y Exposición Escolar: Inauguración Jueves 15 de Agosto de 1889, 5 and "Certámen," Boletín Bibliográfico, December 1, 1888.

${ }^{32}$ Agustín T. Whilar, Colegio Peruano de enseñanza autorizada (Lima: Imp. de Torres Aguirre, 1890) and Colegio Gratuito de Instrucción media (Lima: Imprenta de "El Nacional” por B. Antezana, 1871).
} 
ways, were foundational. Isabel Bressler, for instance, founded the first Peruvian pedagogical newspaper that addressed teaching methods and educational legislation in Peru, bringing debates about education local. ${ }^{33}$ Women founded their own schools, reorganized public school festivities to incorporate readings of student essays, and participated in textbook and pedagogical contests. ${ }^{34}$ They outnumbered men in one of the most active educational associations of the last decades of the nineteenth century, and authored numerous textbooks. ${ }^{35}$ They debated other authors beyond pedagogical newspapers in Lima's leading newspaper El Comercio and in other literary periodicals. ${ }^{36}$ Their ideas were not limited to women's education, but often addressed broader questions on educational methods and the highly politicized conversation over the secularization and centralization of public education.

Scope of Study and Periodization

The scope of the dissertation covers Lima's "long nineteenth century," a periodization that has been useful in clarifying the continuities and changes that societies

\footnotetext{
33 “Fiestas Cívicas,” El Comercio, August 1, 1878.

${ }^{34}$ Ateneo de Lima, Certamen de Textos y Exposición Escolar: Inauguración Jueves 15 de Agosto de 1889 (Lima: Imprenta de la Merced, 1889) and Ateneo de Lima, Certamen de Textos y Exposición Escolar: Distribución de premios y clausura Septiembre 8 de 1889 (Lima: Imprenta y Librerias de Benito Gil, 1889).

35 "Socios fundadores" in Reglamento de La Sociedad de Preceptores (Lima: Imprenta de J. Francisco Solis, 1885), 18.

${ }^{36}$ Fanning, Educación Femenina, 1. Also see Mercedes Cabello de Carbonera, "La Lectura," El Correo del Perú, January 2, 1876; Clorinda Matto de Turner, "La necesidad de la educación física en los colegios," El Perú Ilustrado, March 8, 1890.
} 
across the Atlantic underwent after the tumultuous late eighteenth-and early nineteenthcentury revolutions and the altering processes of industrialization, secularization, technological change, and urbanization of the latter half of the nineteenth century. ${ }^{37}$ While the years that start and end this period vary depending on the monograph or edited volume, scholars who use this periodization seek to avoid the arbitrary divisions of colonial and national or modern histories, which often obscure the actual impact of political independence. ${ }^{38}$ Despite the wide acceptance of this longer periodization, scholarship on the history education as well as works on print culture and the related field of book history have remained remarkably divided along the colonial-modern split. ${ }^{39}$ This is surprising considering historians' own admission that cultural currents tend to move more slowly. ${ }^{40}$

\footnotetext{
${ }^{37}$ The periodization was originally coined by Eric Hobsbawm. See Mark D. Szuchman, The Middle Period in Latin America: Values and Attitudes in the 17th-19th Centuries (Boulder: Lynne Rienner Publishers, 1989) and Stuart F. Voss, Latin America in the Middle Period, 1750-1929 (Scholarly Resources, 2002), xii; Elizabeth Dore, "One Step Forward, Two Steps Back Gender and the State in the Long Nineteenth Century" in Hidden Histories of Gender and the State in Latin America (Duke University Press, 2000).

${ }^{38}$ For the alternative periodization covering the "Age of Revolutions" between 1750-1850, see Victor Uribe-Urán, "Introduction-Beating a Dead Horse," State and Society in Spanish America During the Age of Revolution (Wilmington, Del: SR Books, 2001), xi.

${ }^{39}$ For Peru, most of the scholarship on book commerce, libraries, and print culture focuses on the colonial period, see Pedro Guibovich, El edificio de las letras: Jesuitas, educación y sociedad en el Perú colonial (Lima: Universidad del Pacífico, 2014), 151-152; Teodoro Hampe Martínez, "La historiografía del libro en América hispana: un estado de la cuestion" in Leer en Tiempos de la Colonia: Imprenta, Bibliotecas y Lectores en la Nueva España, ed. by Idalia García and Pedro rueda Ramírez (Mexico City: Universidad Autónoma de México, 2010), 55-72; Luis Martín, The Intellectual Conquest of Peru, The Jesuit College of San Pablo, 1568-1767 (New York: Fordham University Press, 1968); Guillermo Lohmann Villena, "Libros, libreros, y bibliotecas en la época virreinal" in Fénix (Lima), Num. 21 (1971). Antonio Espinoza, "Libros escolares y educación primaria en la ciudad de Lima durante el siglo XIX, Historica (2007): 137 and José Ragas, "Leer, escribir, votar. Literacidad y cultura política en el Perú (1810-1900)," Historica 31 (2007): 115.
}

${ }^{40}$ Voxx, Latin America in the Middle Period," xii. 
Within this long periodization, my dissertation highlights the continuities in reading practices and ideas about reading between the colonial period and the first half of the nineteenth century. It became clear early in my research that tracing historical change in reading culture and ideas about the functions of reading in republican Lima required a deeper examination of colonial reading practices and pedagogical ideas, which shaped the republican educational project of the nineteenth century. Republican leaders inherited Enlightenment ideals that promoted the spread of alphabetic literacy and particularly, the more active role of the state and local governments in educational processes. While legislation and the rhetoric of early republican leaders reflected these ideals, the state lacked the infrastructural power to direct the use of specific school textbooks, methods, and curricula. ${ }^{41}$ Throughout this period, the Catholic Church remained the primary provider of education, which reflected a continued emphasis in moral and religious instruction.

My study reveals that significant changes in Peru's publishing industry and increased collaboration between Lima's civil society and the state enabled a broader and gradual impact of midcentury liberal educational reforms. In 1854, Liberals led a successful revolt and oversaw a series of legal reforms, of which several limited the power of the Church. Liberals abolished the Indian head tax and implemented anticlerical reforms such as the abolition of the Church fuero and the public collection of tithes.

\footnotetext{
${ }^{41}$ Miguel A. Centeno and Agustín E. Ferraro have defined infrastructural power as "the organizational and technical power to process information, build organizational structures, and maintain transportation and communication systems," see "Republics of the Possible: State Building in Latin America and Spain" in State and Nation Making in Latin America and Spain: Republics of the Possible ed. Miguel A. Centeno and Agustín E. Ferraro (Cambridge University Press, 2013), 11-12.
} 
Liberals also began the disentailment of ecclesiastical property. Despite of the anticlericalism of some of these reforms, Liberals sought to maintain an amicable relationship with the Church. The educational code of 1855 , authored by educator Sebastián Lorente (1813-1884), maintained the Church's right to intervene in education, but emphasized the role of the state as the overseer. Under the slogan of "the regeneration of the republic," reformers sought to educate the popular masses, foment patriotism and encourage racial harmony. ${ }^{42}$ Peruvian educators shared some of these nationalist ideals, but they also hoped to modernize pedagogical methods. They advocated for the use of the intuitive method, which emphasized that children learned best through using sensory experience to examine objects in their immediate environment and promoted exposing children to reading about diverse subjects early in school. The goals of reformers and educators were not antithetical. Centralizing education provided a way to ensure the rapid modernization of methods in Peruvian schools. Moreover, modern pedagogical methods prescribed the use of familiar content when teaching reading, writing, geography, arithmetic, and the sciences, which complemented the national government's goals of fomenting patriotism using national content in textbooks. My dissertation shows that the growth of Peru's publishing industry increasingly communicated and politicized a diverse sector of educators, writers, booksellers and editors. Their educational enterprise enabled a gradual implementation of liberal educational reforms by the turn of the nineteenth century. These included the expanded role of the central state in legitimizing textbooks, curricula and methods.

\footnotetext{
${ }^{42}$ Espinoza, Education and the State, 61
} 


\section{Organization of Chapters}

The first chapter examines the inherited educational institutions and reading culture from the colonial period. The first section examines the introduction of alphabetic literacy in the New World. It describes the role of religious indoctrination in circumscribing ideas about reading and education during the sixteenth and seventeenth centuries. The objective of basic education for colonial state and ecclesiastical authorities was not to form proficient readers or writers. Teaching the rudiments of reading and writing functioned as an auxiliary tool in the religious indoctrination of the masses. ${ }^{43}$ Most of the available literature reflected the centrality of religion to colonial society and consisted of books of hours, religious catechisms and reading books, prayer and devotional literature. ${ }^{44}$ Elites certainly had more access to varied scientific literature and recreational novels, and plebeians orally passed on excerpts of poetry, fables, songs, and other forms of recreational text, but for most people, the act of reading and interpreting text remained circumscribed by an ecclesiastical authority or an orator.

Religious indoctrination remained a central component of education through the eighteenth century, but Enlightenment thought began to influence how Bourbon reformers and some local teachers thought about education. Changing notions about

\footnotetext{
43 "Dorothy Tanck de Estrada, "La enseñanza de la lectura y de la escritura en la Nueva España, 17001821" in Independencia y educación (El Colegio de Mexico, 2013), 25 and Pilar Gonzalbo Aizpuru, "Leer de la infancia a la vejez: El buen orden de las lecturas en la colonia," in Leer en tiempos de la Colonia: imprenta, bibliotecas y lectores en la Nueva España, ed. Idalia García Aguilar and Pedro Rueda Ramírez (Universidad Nacional Autónoma de México, 2010), 24.

${ }^{44}$ Pedro Guibovich, Censura, libros e inquisición en el Perú colonial, 1570-1754 (Sevilla: Consejo Superior de Investigaciones Científicas, Escuela de Estudios Hispano-Americanos, Universidad de Sevilla, Diputación de Sevilla, 2003), 206. Also see Nancy E. Van Deusen, "El Cuerpo como libro viviente (Lima, 1600-1640)," Histórica, XXXI.1 (2007), 21.
} 
education and the uses of alphabetic literacy are evident in the writings of Esteban de Orellana and Gaspar Melchor de Jovellanos and in early republican legislation. ${ }^{45}$ Using newspaper accounts, the chapter assesses the impact of these ideas on the educational literature available in the early nineteenth century. Modern ideas about education and alphabetic literacy created a demand for didactic materials and stimulated Lima's book commerce, however, Lima's publishing industry remained underdeveloped and European imported texts, translations, and compilations continued to dominate this commerce.

Chapter two presents a history of Lima's public library, which more than any other component of the republican project, represented a commitment to democratizing reading practices and spreading enlightenment among people who previously lacked access to books and were thus shut out of the "republic of letters." 46 The library also symbolized intellectual independence and departure from a tyrannical and decadent Spain, a view articulated in the anti-Spanish and nationalist discourse of founders and administrators involved in the establishment of the library. ${ }^{47}$ The chapter examines regulations and administrative documents pertaining to the institution. It uncovers the contradictory functions outlined for Lima's public library by its founders and

\footnotetext{
${ }^{45}$ Esteban de Orellana, Instrucción de la Lengua Latina o Arte de adquirirla por la traducción de los autores (Lima: En la Oficina de los Niños Expósitos, 1759); and Gaspar Melchor de Jovellanos, "Bases para la formación de un plan general de instrucción" and "Memoria sobre educación pública ó sea tratado teórico-práctico de enseñanza, con aplicación á las escuelas y colegios de niños" in Obras publicadas e inéditas de D. Gaspar Melchor de Jovellanos, ed. by Cándido Nocedal (Madrid: M. Rivadeneyra, 1858).

${ }^{46}$ Deena Goodman, The Republic of Letters: A Cultural History of the French Enlightenment (Cornell University Press, 1994), ix.

47 "Estableciendo una biblioteca pública en Lima," August 28, 1821 and "Estreno de la Biblioteca Nacional," Gaceta del gobierno de Lima, September 18, 1822 in the Archivo Digital de la Legislación del Perú (ADLP).
} 
administrators as well as the everyday realities that shaped the experiences of library users. For much of the nineteenth century, elites' own limited visions for the institution, political instability, insufficient funding, and understaffing limited the library's functionality for diverse groups. As Lima's literacy rates increased at the end of the nineteenth century and more visitors began to use the services of the institution, administrative sources reveal the tensions between elitist and democratic models of reading.

Chapter three captures the emergence of a national book and textbook industry, which began to meet broad demand for educational and recreational literature. While several of the booksellers who established publishing houses in Lima were foreign-bornincluding Benito Gil (Spain), Juan Galland and Carlos Prince (France) - they expressed their own fervent nationalism and allegiance to their adoptive country and exploited calls from the government and private educators to develop a national book and textbook industry. Many of the didactic books and textbooks that booksellers chose to edit, publish or advertise were written or compiled by Peruvian authors or immigrants settled in Lima. They also began to include content about the country's history, culture, and geography. Subjects in "popular libraries" or collections of books that targeted the masses addressed local traditions, containing compilations of popular music, cooking recipes, or advice and useful "tips." This literature represented local customs and practices as Peruvian or national, often belying their mixed origins, but connecting individuals to an "imagined community" in ways the state had failed to do for decades after independence. ${ }^{48}$

\footnotetext{
${ }^{48}$ On the concept of "imagined communities" see Benedict Anderson, Imagined Communities: Reflections on the Origin and Spread of Nationalism (London: Verso, 1983). For a critical view of the concept,
} 
The study of Lima's bookstores reveals their significance beyond the transformation of reading practices in the city. This process enabled the central government to adopt national textbooks for their use in Peruvian schools. Before 1855, the central government had only sanctioned four specific texts for their use in Peruvian schools of all levels. ${ }^{49}$ After that year, the list doubled several times. National educational authorities approved twelve books between 1850 and 1859, twenty between 1860 and 1869, forty-five between 1870 and 1879, ten between 1880 and 1889, and 119 between 1890 and $1900 .^{50}$ This trend only saw a dip during the difficult decade of the 1880s. During this time, the country began to recover from the devastating War of the Pacific (1879-1883) and subsequent civil war, which interrupted the activities of merchants, printing houses and government. The state thus coopted the disjointed efforts of a broad range of enthusiasts of education rather than create a textbook industry that is often associated with the twentieth century Teaching State. Although perceived as weak, the nineteenth-century Peruvian state managed to increasingly mediate and legitimize the ideas, images, and information received by the country's youth.

particularly for the chronology that pertains to Latin America, see Sara Castro-Klarén and John Charles Chasteen, Beyond Imagined Communities: Reading and Writing the Nation in Nineteenth-Century Latin America (Washington, D.C.: Woodrow Wilson Center Press, 2003).

${ }^{49}$ Juan Oviedo, Colección de Leyes, Decretos y Ordenes publicadas en el Perú desde al año 1821 hasta el 31 de diciembre de 1859 (Lima: Felipe Bailly, 1862)120. Historian Antonio Espinoza cited Antonio González's, Catecismo político para la primera enseñanza de las escuelas de la república del Perú as approved by Simón Bolivar in 1825, see Antonio Espinoza, "Libros escolares y educación primaria en la ciudad de Lima durante el siglo XIX," Histórica, XXXI.1 (2007): 135-170.

${ }^{50}$ I found this information in dispersed documents including Memoria que presenta el ministro de justicia, instrucción y culto al congreso ordinario de 1901 (Lima: Imprenta del Estado, 1901), 868.15-868.21.

"Secretaria del Consejo Superior de Instrucción Pública—Razón de los textos aprobados desde 1855 hasta la fecha" in El Faro (Lima) December 16, 1889; January 1, 1890; and February 16, 1890. Missing titles in El Faro and the 1901 Memoria can be found in "Inserciones Relación de los textos aprobados por el Consejo Superior de Instrucción cuya autorización está vigente," El Comercio (Lima), October 29, 1897. 
The expansion of Lima's publishing industry, as previously discussed, also reveals much about the growth of the city's "public sphere," the focus of chapter four. The chapter describes how the publishing industry enabled the foundation of Peruvian pedagogical newspapers that communicated the endeavors of diverse individuals involved in private as well as public educational enterprise. As a result, many intellectual competitions and pedagogical conferences were organized in the last three decades of the nineteenth century. These events were often combined with civic festivities with nationalist rhetoric. Individuals affiliated with central or local governments were involved to different degrees, and the state sometimes subsidized pedagogical newspapers or provided the physical venues for festivities or points of reunion. This process broadened the public spaces through which enthusiasts of education legitimized their schools, teaching methods, textbooks, and other educational enterprise. Pedagogical newspapers, such as $L a$ Instrucción, El Faro and later, La Escuela Peruana became instruments through which enthusiasts of education influenced school culture as well as educational reform, despite the remarks of some editors who insisted that the periodicals were not political newspapers. Given the extent of the involvement of state actors in Lima's pedagogical public sphere, but also the critical debate produced through its various venues, this chapter questions the rigid structures of the classical Habermasian model of the public sphere, which erects a false dichotomy between venues of public exchange and the structures of the state."51

The conclusion reflects on the significance of the presence of a "pedagogical" public sphere through which enthusiasts of education influenced the course of institutions

\footnotetext{
${ }^{51}$ Jeremy L. Caradonna, The Enlightenment in Practice: Academic Prize Contests and Intellectual Culture in France, 1670-1794 (Cornell University Press, 2012), 7.
} 
of the modern nation state in Peru. To understand the growth of the Peruvian Teaching State in the early twentieth century, it is necessary to understand the interactions between the state and civil society during the nineteenth century. As Miguel A. Centeno and Agustín E. Ferraro succinctly noted, "modern state administrative organizations have rarely been monocratic; they develop as an array of bureaucratic organizations variously linked to power networks in civil society." ${ }^{52}$ Moreover, "the expansion of infrastructural penetration predictably goes both ways: as a result of the embeddedness of relatively autonomous bureaucratic organizations, civil society's capacity to bring influence to bear on the state also increases. The expansion of infrastructural power occurs simultaneously with the widespread politicization of civil society." $" 53$

The conclusion also encourages a reassessment of our traditional narratives of the relationship between education and nation in Latin America and beyond. Often, these narratives place Liberals and Conservatives at odds, with the first adhering to a Europeanized and secular model of education, and the second to more traditional forms of education involving extensive Church control, and moral and religious instruction. While this dichotomy certainly shaped debates in the early republic, by th last decades of the nineteenth century, educators became more concerned with institutionalizing the hallmarks of pedagogical modernity by developing a textbook industry with national content, implementing curricula with diverse subjects and reading materials, and promoting the use of the intuitive method in classrooms. The growth in Lima's literacy

\footnotetext{
${ }^{52}$ Centeno and Ferraro, "Republics of the Possible: State Building in Latin America and Spain," 12. ${ }^{53}$ Ibid.
} 
rates and the pervasiveness of reading culture by the early twentieth century demonstrates the success of their efforts.

\section{CHAPTER I}

Alphabetic Literacy and Reading Culture from Colonial to Early Republican Lima 
Spanish Americans imported from Europe as much as eighty-five percent of the books that circulated Spain's American colonies. ${ }^{54}$ During the sixteenth and seventeenth centuries, about seventy percent of these books addressed religious subjects. ${ }^{55}$ The centrality of religion to social life as well as the abundant Spanish legislation that regulated printing licenses and prohibited a variety of books shaped the contours of reading culture throughout the colonial period. ${ }^{56}$ The scarcity of works produced in Spanish America about American subjects and Spain's restrictions on a broad range of literature supported the anti-Spanish discourse of José de San Martín and other Independence leaders. They emphasized their commitment to popular enlightenment and departure from a tyrannical and decadent Spain by promising to improve the circulation of educational texts and calling for the creation of national literature. ${ }^{57}$ In recent decades,

${ }^{54}$ Teodoro Hampe Martínez, "Bibliotecas, imprentas y difusión de noticias en el Perú colonial," Bulletin hispanique, 113-1 (2011): 414.

${ }^{55}$ Leonard, Books of the Brave: being an account of books and of men in the Spanish conquest and settlement of the sixteenth-century NewWorld, with a new introduction by Rolena Adorno (Berkeley, CA, 1992), 105.

${ }^{56}$ See especially José Toribio Medina's monumental work Biblioteca hispano-americana (1493-1810) on printing during the colonial period. For an additional discussion see Roberto González Echevarría, "A Brief History of the History of Spanish American Literature," in The Cambridge History of Latin American Literature, ed. González Echevarría and Enrique Pupo-Walker (Cambridge: Cambridge University Press, 1996), 11-12 and Hortensia Calvo, "The Politics of Print: The Historiography of the Book in Early Spanish America," Book History Vol. 6 (2003): 280-1.

${ }^{57}$ For example, in a decree ordering the foundation of a national library in Lima, San Martín noted "Convencido sin duda el gobierno español de que la ignorancia es la columna mas firme del despotismo, puso las mas fuertes trabas á la ilustración del amiercano, manteniendo su pensamiento encadenado para impedir que adquiriese el conocimiento de su dignidad." See "Mandando establecer una Biblioteca pública en Lima," August 28, 1821 in Juan Oviedo, Colección de Leyes, Decretos y Ordenes publicadas en el Perú desde el año 1821 hasta 31 de diciembre de 1859, Tomo IV: Ministerio de Beneficencia, Instrucción y Justicia (Lima: Felipe Bailly, 1862), 93. On these cultural justifications for political independence, see Pedro Guibovich, "La usurpación de la memoria: el patrimonio documental y bibliográfico durante la ocupación chilena de Lima, 1881-1883," Jahrbuch für Geschichte Lateinamerikas 46 (2009), 89-90; and William Acree, Everyday Reading: Print Culture and Collective Identity in the Río de la Plata, 1780-1910 (Nashville: Vanderbilt University, 2011), 27-30. On the broader political use of anti-Spanish rhetoric and its origins in the "Black Legend" see Wim Klooster, Revolutions, in the Atlantic World: A Comparative History (New York: New York University Press, 2009), 147-148. 
historians of the book have dispelled such obscurantist views, uncovering a much broader range of reading materials that circulated in Spanish colonies. ${ }^{58}$ In restricting their work to a colonial periodization, however, these scholars say little about reading culture in the transition from colony to nation. This chapter examines reading practices and educational ideas about alphabetic literacy through early republican Lima, contributing to a better understanding of the relationship between reading and nation building in this early period. It argues that after Independence, the weak Peruvian state and Lima's developing print industry were unable to meet the growing demand for education and reading materials, which led to the expansion of Eurocentric reading culture and limited the nation-building efforts of political elites.

Since the publication of Benedict Anderson's Imagined Communities numerous studies have adopted the book's overall theorization of the central role of print—and by extension, the role of reading and writing - in the social construction of nation, but for scholars of Latin America, the book makes questionable chronological assertions about the formation of national identities in the region. ${ }^{59}$ Anderson's overall framework

\footnotetext{
${ }^{58}$ This historiographical vein can be traced to the work of Irving Leonard and José Torre Revello. Leonard first published Books of the Brave in 1949 largely as a challenge to charges of Spanish obscurantism. The same year, Torre Revello publshed El libro, la imprenta y el periodismo en América durante la dominación española (Buenos Aires: Jacobo Peuser, 1949). More recent works include Teodoro Hampe Martínez, Bibliotecas privadas en el mundo colonial: La difusión de libros e ideas en el virreinato del Perú, siglos SVI-XVII (Frankfurt: Vervuert, 1996); César Mexicano, "Libros y cultura en el Perú Colonial. Una librería popular en la Calle de Palacio, 1781" in Educación y libros en el Perú, época colonial y republicana (Lima: 2005), 26-27; Carlos Alberto González Sánchez, "Emigrantes y comercio de libros en el virreinato del Perú," Biblios, Vol. 2, No 6 (1993): 1-18 and Pedro Gubovich, "Las lecturas de Francisco de Isásaga," Histórica (Lima) 10 (1986): 191-212.

${ }^{59}$ See for example the studies in Sara Castro-Klarén and John Charles Chasteen, Beyond Imagined Communities: Reading and Writing the Nation in Nineteenth-Century Latin America (Baltimore and London: The Johns Hopkins University Press, 2003).
} 
outlined the function of print in the formation of national identities in Europe, Latin America, and how these models were later replicated in imperialist projects and the postcolonial world. ${ }^{60}$ His chapter on Latin America, "Creole Pioneers," asserted that national consciousness predated the wars of independence and defined the boundaries of the resulting independent republics. ${ }^{61}$ Anderson cited the role of colonial newspapers, as well as the role bureaucratic posts that were circumscribed by territorial limits, in promoting notions of political community attached to specific regions that later defined the limits of nation states. Latin American scholars generally disagree with this chronology, arguing that nationalisms in the region only consolidated after 1850 when export-driven economic growth produced robust tax revenues for the state. These revenues helped the state expand social infrastructure and state institutions, effective national bureaucracies, school systems, disciplined armies and police forces. ${ }^{62}$ Moreover, they note that this period saw the construction of railroads, and the use of steamships and the telegraph, which improved communications between capitals and their provinces. Improved transportation and communication infrastructure broadened the circulation of print, thus helping the state reach its provinces with ideological messages that "create

\footnotetext{
${ }^{60}$ Benedict Anderson, Imagined Communities: Reflections on the Origin and Spread of Nationalism (London: Verso, 1983).

${ }^{61}$ Ibid, 47-66.

${ }^{62}$ John Charles Chasteen, "Introduction: Beyond Imagined Communities," in Beyond Imagined Communities, xviii.
} 
collectives that view themselves as such and that provide the foundational legitimacy for state claims to power."63

This chapter agrees with the consensus that nationalism in Latin America developed in the second half of the nineteenth century; however, it also argues the case of Lima highlights the role of a preexisting (and expanding) Eurocentric reading culture in precluding the spread of top-down or official constructions of national identity. During the early republican period, print culture generally worked against rather than in service of the nation-building efforts of elites. As republican leaders passed constitutional provisions to protect freedom of the press and limeños demanded more reading material particularly for educational purposes, a broad range of European educational literature, newspapers and novels flooded Lima's bookstores. This educational literature far outnumbered locally produced texts. Until 1855, for instance, only one civic catechism, Antonio González's Catecismo Político, appears to have been published in Peru. Moreover, there is no evidence that it was sold by Lima's book merchants or that it circulated in the city. ${ }^{64}$ According to Peruvian statistician, Manuel Atanasio Fuentes, less than five percent of the overall books published in Lima between 1821 and 1858 could be categorized as educational books. ${ }^{65}$

\footnotetext{
${ }^{63}$ Miguel A. Centeno and Agustín E. Ferraro, "Republics of the Possible: State Building in Latin America," in State and Nation Making in Latin America and Spain: Republics of the Possible (Cambridge University Press, 2013), 13.

${ }^{64}$ Antonio González, Catecismo Político (Arequipa: Imprenta del Gobierno, 1825). The book does not appear in my own research of bookstore advertisements or as required reading in curricular legislation. Antonio Espinoza reached a similar conclusion on this book based on his previous research. See "Libros Escolares y educación primaria en la ciudad de Lima durante el siglo XIX," Histórica, XXXI.1 (2007), 136.

${ }^{65}$ Ibid, 184.
} 
Even literature that addressed the history of the Americas came through the prism European writers. This was the case with a translation, available from several of Lima's book merchants, of William Robertson's Historia de la América, which reproduced eighteenth-century notions of European superiority based on naturalist degeneration theories. ${ }^{66}$ Instead of promoting Peruvian nationalism or simply knowledge of the boundaries and territorial limits of the country, the aggregate of available literature deepened familiarity with European culture.

The chapter begins with a discussion of the introduction of alphabetic literacy in the New World and the role of religious indoctrination in circumscribing ideas about reading and education during the sixteenth and seventeenth centuries. The extensive secondary literature on colonial libraries and book commerce provides a comprehensive view of the influence and limits of church and state authorities in the formation of reading culture during the early to middle colonial period. The second section addresses changing eighteenth-century notions about education and the uses of alphabetic literacy in colonial society as well as the impact of these ideas on educators across the Atlantic, including Esteban de Orellana and Gaspar Melchor de Jovellanos. The chapter ends with an analysis of the expansion of book commerce in the early nineteenth century. Modern ideas about education and alphabetic literacy created a demand for didactic materials that the state and Lima's underdeveloped publishing industry could not meet; however, constitutional provisions protecting freedom of the press ensured that a broad range of foreign print became available. Legislation, newspaper articles and advertisements as

\footnotetext{
${ }^{66}$ See "En la Tienda numero 22," Mercurio Peruano, March 11, 1828 and "Libros," Mercurio Peruano, January $21,1829$.
} 
well as published statistical sources help examine the range of reading materials available to limeños. They included European translations, compilations and modified copies of European educational texts from Spain, France and Britain. These materials reflected the expansion of Eurocentric reading culture in the early republic.

The Alphabet of Religion

Although diverse religious, state and municipal institutions provided instruction to Spanish colonial subjects, religious indoctrination remained the centerpiece of basic education for most of the colonial period. The papal bull Inter Caetera of 1493 first granted Spain and Portugal the legal justification to colonize parts of the New World but also required they convert indigenous neophytes to the Catholic faith and teach them Iberian civility (buenas costumbres). ${ }^{67}$ Within a few decades, Spanish military campaigns subdued Tenochtitlan and Cuzco, the populous capitals of the Aztec and Inca empires. Spain established the Viceroyalties of New Spain in 1535 and Peru in 1542. Catholic priests accompanied many of the first conquistadors and began establishing missions to evangelize natives. They proselytized to indigenous communities during church sermons and catechism (doctrina) ${ }^{68}$ Children and adults were expected to memorize Catholic prayers, the Ten Commandments, and other religious precepts read out loud by priests.

Church and state authorities commanded priests to provide more advanced education to indigenous elites in order to employ their help in the daunting task of

\footnotetext{
${ }^{67}$ Monique Alaperrine-Bouyer, La educación de las elites indígenas en el Perú colonial (Lima: Instituto Francés de Estudios Andinos, 2007), 13.

${ }^{68} \mathrm{Ibid}, 14$.
} 
indoctrinating multitudes. The crown also sought to introduce alphabetic literacy among native chieftains (kurakas) to keep them as heads of former Inca governing units. In their new roles, native leaders functioned as intermediaries between the Spanish administration and indigenous communities and took charge of the collection of tribute tax and implementation of forced labor drafts. ${ }^{69}$ Understanding the power of reading and writing within the new colonial administration, indigenous leaders embraced alphabetic literacy and demanded the fulfillment of royal decrees that called for the establishment of seminary schools for native nobles. ${ }^{70}$ In several cases, indigenous nobles and their descendants kept their positions as kurakas or became presbyters, but they also took jobs as scribes or became critical intellectuals who used alphabetic literacy to challenge Spanish authority through legal activism and textual production. ${ }^{71}$

\footnotetext{
${ }^{69}$ On the role of native leaders as intermediaries between the demands of native communities and Spanish administrators as well as their agency in the construction of a hybrid colonial culture, see Yanna Yannakakis, The Art of Being In-Between: Native Intermediaries, Indian Identity, and Local Rule in Colonial Oaxaca (Durham and London: Duke University Press, 2008) and Alcira Dueñas, Indians and Mestizos in the "Lettered City": Reshaping Justice, Social Hierarchy, and Political Culture in Colonial Peru (Boulder, CO: University Press of Colorado, 2010).

${ }^{70}$ Alcira Dueñas, Indians and Mestizos in the "Lettered City," 16. Early successes in educating indigenous elites resulted in tensions between different sectors of the colonial population. Hoping to maintain power through the monopolization of the written word, some Spaniards and creoles "systematically opposed" the foundation of seminaries in Peru for native elites, see Monique Alaperrine-Bouyer, La educación de las elites indigenas en el Peru colonial, 47-71. The Andean textual production of indigenous and mestizo writers from the sixteenth and early seventeenth centuries including the work of Santacruz Pachacuti Yamki Salcamaigua, Titu Cusi Yupanqui, Inca Garcilaso de la Vega, and Felipe Guamán Poma de Ayala attests to the early educational successes of Spanish priests and the disposition of their pupils. See the edited volume by Rolena Adorno, From Oral to Written Expression: Native Andean Chronicles from the Early Colonial Period (Syracuse, NY: Maxwell School of Citizenship and Public Affairs, Syracuse University, 1982) and Sara Castro-Klaren, "El orden del sujeto en Guaman Poma," Revista de crítica literaria latinoamericana 41 (1995): 121-134.
}

${ }^{71}$ Alcira Dueñas, Indians and Mestizos in the "Lettered City," 6. Also see Rolena Adorno, Guaman Poma: Writing and Resistance in Colonial Peru (University of Texas Press, 1986). Several Andean scholars have highlighted the appropriation of alphabetic literacy by indigenous writers, but they also stretch the limits of Angel Rama's "lettered city" by analyzing the interactions of illiterate subjects with scribal culture, particularly in the legal sphere. See Angel Rama, The Lettered City (Duke University Press, 1996); José Ramón Jouve-Martin, Esclavos de la ciudad letrada: Esclavitud, escritura, y colonialismo en Lima (16501700) (Lima: Instituto de Estudios Peruanos, 2005); Kathryn Burns, Into the Archive: Writing and Power in 
The evangelization and literacy campaigns and the efforts of some natives willing to work with the Spanish priests yielded a significant number of catechisms, grammar and vocabulary books, and instructional religious tracts in native languages. In Peru, the native population helped priests translate Catholic doctrine into the aboriginal languages of Quechua and Aymara. ${ }^{72}$ This collaboration helped create and publish seventeen catechistic texts between 1582 and 1620 in Lima. Historian Pedro Guibovich has called this period the "golden age" of catechistic literature in Peru. ${ }^{73}$ In Mexico, early accounts noted the alphabetic literacy of many natives. ${ }^{74}$ They helped priests develop pictographic reading books with images intended to approach the reading of hieroglyphics in Mesoamerican writing systems. Rather than transmitting a singular phonetic sound or representation, the images had both a morphological and semantic meaning. ${ }^{75}$ By the seventeenth century, locally produced literature in native languages declined. In Mexico, this production fell from thirty-one percent between 1539 and 1600, to three percent in the seventeenth century. ${ }^{76}$ Concerns with heretical books and literature

Colonial Peru (Duke University Press, 2010); Bianca Premo, The Enlightenment on Trial: Ordinary Litigants and Colonialism in the Spanish Empire (Oxford, 2017).

72 Pedro Guibovich, El edificio de las letras. Jesuitas, educación y sociedad en el Perú colonial (Lima: Universidad del Pacífico, 2014), 123-125.

${ }^{73}$ Ibid, 117.

${ }^{74}$ Sixteenth-century priest Fray Pedro de Córdoba stated that there were many natives in Mexico who could read (hay tantos dellos que saben leer), see Pilar Gonzalbo Aizpuru, "Leer de la infancia a la vejez. El buen orden de las lecturas en la Colonia" in Leer en Tiempos de la colonia: Imprenta, Bibliotecas y Lectores en la Nueva España, ed. Idalia García et al. (Universidad Autónoma de México, 2010), 27.

75 Ibid, 25.

76 These figures are based on work by Magdalena Chocano Mena, discussed in Hortensia Calvo, "The Politics of Print: The Historiography of the Book in Early Spanish America," Book History Vol. 6 (2003): 279. 
that promoted the "Black Legend" led to a series of decrees that curtailed local printing throughout Spanish colonies. ${ }^{77}$ The crown imparted censorship through the strict control of printing licenses and after 1570, inquisitors in Lima controlled book imports to Peru. If not always efficiently, the Holy Office rejected heretical books listed on indexes published independently in Madrid and Rome. In addition to prohibiting texts that might question Spanish or Church authority, the indexes banned books of purely literary content. ${ }^{78}$ Concerns that fictional literature — chivalric novels, fables, and other fantastical works - might become a source of confusion for newly converted natives led Spanish authorities to ban books under these categories. ${ }^{79}$

The decline of published works in Amerindian languages also resulted from a demographic decline in the native population and growing local and state concern with the education of Spanish and mestizo populations. A variety of educational institutions and schools that targeted the latter proliferated in the seventeenth century. If parents could afford to pay private teachers, they hired tutors and later institutionalized their children in convents or seminaries for more advanced education.

Some parents sent their children to neighborhood private teachers called "amigas" or "migas." Usually from their homes, migas operated schools that combined elements of primary schools and nurseries. They taught a small number of children using an individual

\footnotetext{
${ }^{77}$ Marcela Zúñiga Saldaña, “El 'santo oficio' de los calificadores de libros en la Nueva España del siglo XVIII" in Del autor al lector I. Historia del libro en México II. Historia del libro, ed. Carmen Castañeda et. al (Mexico City: Centro de Investigaciones y Estudios Superiores en Antropologia Social, CIESAS, 2002), 183.

${ }^{78} \mathrm{Ibid}, 188$. A total of 9 indexes were published between the sixteenth and eighteenth centuries, three in each century.

${ }^{79}$ Pilar Conzalbo Aizpuru, "Leer de la infancia a la vejez. El buen orden de las lecturas en la Colonia,” 62.
} 
method whereby the teachers called on each student and introduced him or her to the alphabet using a cartilla or reading book. ${ }^{80}$ Most cartillas were written by Spanish authors and published in Spain or reprinted in the colonies by a small number of individuals or institutions with printing licenses. ${ }^{81}$ The first section of the cartilla acquainted the child with the alphabet, the second introduced abstract syllables, and the third included familiar Catholic prayers. ${ }^{82}$

Some religious and secular institutions operated more formal schools where foundlings and poor children received early education. They provided reading lessons during the first year of schooling, and writing and arithmetic lessons during the second or third years. This method resulted in many more children learning how to read than write because most children only finished the first year. For many colonial educators, however, one year of schooling sufficed. Writing was considered a superfluous skill for most people while knowledge in the rudiments of reading functioned as an auxiliary tool for teaching religion to the masses. ${ }^{83}$ In Lima's foundling home, some older students received additional gendered instruction in different crafts. Girls learned how to sew and do other domestic work, while boys learned handicrafts. Ultimately, administrators of the foundling

\footnotetext{
${ }^{80}$ Dorothy Tanck de Estrada, "La vida escolar antes y después de la independencia in Independencia y educación (El Colegio de Mexico, 2013), 282.

${ }^{81}$ Some of the cartillas published during this period include Arte para enseñar a leer perfectamente $y$ en muy breve tiempo, compuesto según la vía o perfecta orden del deletrear, Arte para aprender a leer y escribir perfectamente en romance y latín, and Cartilla o arte breve y bien compendiosa para enseñar a deletrear y leer perfectamente y con mucha facilidad y con todas las mas abreviaturas que se pudieran hallar. See Dorothy Tanck de Estrada, "La enseñanza de la lectura y de la escritura en la Nueva España, 1700-1821" in Independencia y educación (El Colegio de Mexico, 2013), 26-27.

${ }^{82}$ Dorothy Tanck de Estrada, "La enseñanza de la lectura y de la escritura en la Nueva España, 1700-1821" in Independencia y educación (El Colegio de Mexico, 2013): 26-30.

${ }^{83} \mathrm{Ibid}, 25$.
} 
home hoped to place nonwhite children over eight years of age in a "school, an apprenticeship or domestic service." 84

After their elementary education, Spanish boys had the option of continuing their education in secondary schools (colegios) where they took courses in the humanities (Spanish grammar, Latin, rhetoric and the arts), literature, logic, and mathematics. Some colegios also taught courses in physics and philosophy. In Lima, elite boys of Spanish descent could further their studies at the Universidad de San Marcos, enrolling in the faculties of Theology, Arts, Canon Law, or eventually, in the faculties of Medicine or Civil Law. Advanced education in San Marcos and other advanced secondary schools (colegios mayores) generally trained elite Spanish and creole male students for careers as government officials, priests, and jurists. ${ }^{85}$

This privileged class of male students had direct access to colonial institutional libraries. Some of the richest colonial libraries belonged to religious congregations or educational institutions like the Jesuit Colegio de San Pablo. Ordained priests and professors of San Pablo could borrow books from the "common" library, which by the eighteenth century, held a collection of nearly ten thousand volumes in the fields of theology and religion but also in the subjects of history, medicine, geography, political economy, astrology, politics, law, linguistics and grammar. ${ }^{86}$ Another library in San Pablo

\footnotetext{
${ }^{84}$ Bianca Premo, Children of the Father King: Youth, Authority, and Legal Minority in Colonial Lima (The University of North Carolina Press, 2005), 102-103.

${ }^{85}$ Guibovich, El edificio de las letras, 23-36.

${ }^{86}$ Luis Martín, The Intellectual Conquest of Peru: The Jesuit College of San Pablo, 1568-1767 (Fordham University Press, 1968), 87-96. The figure for the number of volumes is from Guibovich, El edificio de las letras, 150.
} 
was "always open to students" but only held a few hundred volumes, which contained works from Greek and Roman authors, theological and philosophical works, and a small selection of modern Spanish books. ${ }^{87}$ The books in this library needed to be carefully selected and approved in order to prevent young students from reading harmful and immoral texts that might lead them astray. ${ }^{88}$

Elites also had the economic means to purchase books from local merchants or obtain them directly from Europe during their travels or via a traveling acquaintance. ${ }^{89}$ The colonial book trade was less the business of exclusive, bricks-and-mortar retail bookshop owners and more the occupation of a variety of merchants who sold miscellaneous items and of travelers and administrators involved in fulfilling personal requests. ${ }^{90}$

Hagiographies, catechisms, liturgical manuals and other sanctioned books on religion and morality constituted as much as 70 percent of books that circulated during the sixteenth and seventeenth centuries. ${ }^{91}$ The other 30 percent included works of fiction,

\footnotetext{
${ }^{87}$ Luis Martín, The Intellectual Conquest of Peru, 81.

${ }^{88}$ Guibovich, El edificio de las letras, 150-1.

${ }^{89}$ Guibovich, "La literatura francesa en el virreinato del Perú: comercio legal y contrabando en el period tardío colonial" Historica XXXI.1 (2007): 85-105.
}

\footnotetext{
${ }^{90}$ Some scholars have been unable to locate the addresses of actual bookstores, while highlighting the informal characteristic of the colonial book trade. This included a number of street vendors who sold second hand books. Mexicano uses the term "librería" or bookstore to describe the commerce of books conducted in certain colonial "cajones" or small miscellaneous stores. See César Mexicano, "Libros y cultura en el Perú Colonial. Una librería popular en la Calle de Palacio, 1781" in Educación y libros en el Perú, época colonial y republicana (Lima: 2005), 15-16. Pedro Guibovich notes that a very limited number of establishments sold books during the eighteenth century, see "La literatura francesa en el virreinato del Perú" and "Libros para ser vendidos en el virreinato del Perú a fines del siglo XVI." Also see Carlos Alberto González Sánchez, "Emigrantes y comercio de libros en el virreinato del Perú," Biblios, Vol. 2, No 6 (1993): 1-18.

${ }^{91}$ Irving Leonard estimated that religious works made up as much as 70 percent of the colonial book trade, see Books of the Brave: being an account of books and of men in the Spanish conquest and settlement of the sixteenth-century NewWorld, with a new introduction by Rolena Adorno (Berkeley, CA, 1992), 105. More recent works similarly found that a majority of books were in the religious category. See Mexicano,
} 
Greek and Latin classics, and specialized books in the humanities, linguistics, law, medicine, history, and political administration. Novels from Spain's Golden Age authors such as Miguel de Cervantes, Félix Lope de Vega, Francisco de Quevedo, and others could be found in the private libraries of sixteenth and seventeenth-century Spanish aristocrats, high level ecclesiastics and administrators, and rich merchants. Don Quijote and picaresque novels like Guzmán de Alfarache as well as prohibited chivalric novels figured prominently despite restrictions and prohibitions by state and religious authorities. ${ }^{92}$

Most people outside the aristocracy did not own books or have access to other printed material, a circumstance that limited the merits of reading instruction and likely, overall alphabetic literacy rates. ${ }^{93}$ Historians estimate that between 10 and 20 percent of the overall population in Spanish America was literate, with higher rates corresponding to urban centers. ${ }^{94}$ We do not have exact figures for the overall population of Lima, but

\footnotetext{
"Libros y cultura en el Perú Colonial. Una librería popular en la Calle de Palacio, 1781," 26-27; and Guibovich, "Libros para ser vendidos en el virreinato del Perú," 89.

${ }^{92}$ Hampe Martínez, "El eco de los ingenios: Literatura española del siglo de oro en las bibliotecas y librerías del Perú colonial" Historica, Vol. XVI No. 2 (Dec 1992): 177-201; Calvo, "The Politics of Print," 283.

${ }^{93}$ See Francois Xavier Guerra, Modernidad e independencias: Ensayos sobre las revoluciones hispanas (México: MAPFRE-Fondo de Cultura Economica, 1993) and Francois Xavier Guerra, Annick Lempérière, et al., Los espacios públicos en Hispanoamérica: Ambiguedades y problemas, siglos XVIII-XIX (México: Centro Francés de Estudios Mexicanos y Centroamericanos-Fondo de Cultura Económica, 1998). Towards the end of the eighteenth century, however, Spanish Americans did gain more access to a variety of pamphlets, books, and other printed materials, a process that points to higher literacy rates and more diverse readerships. For an overview of this period, see Victor Uribe-Uran, "The Birth of the Public Sphere in Latin America during the Age of Revolution," Comparative Studies in Society and History, Vol. 42, No. 2 (Apr., 2000): 425-457.

${ }^{94}$ For Colombia, José Manuel Restrepo argued that during the eighteenth century, the lack of "primary schools left at least 80 percent of New Granada's population illiterate." Restrepo's work is mentioned in Rebecca Earle, "Information and Disinformation in Late Colonial New Granada" in The Americas, Vol. 54, No. 2 (Oct 1997): 169. Carlos Newland estimated that the overall literacy rate for Spanish America during the colonial period hovered around 10 percent, but this figure considers both colonial centers and rural areas, see Carlos Newland, "La educación elemental en Hispanoamerica: Desde la independencia hasta la
} 
approximately 20 percent of school-age Limeños could read in late eighteenth century. Moreover, 12 percent of people between 8 and 21 years of age received education in the city's schools. ${ }^{95}$ Although it is likely that an additional number of people learned how to read and write outside of formal schools, these figures are consistent with estimates for other parts of Spanish-America. As book historian Robert Darnton has pointed out, however, these numbers are problematic as indicators of a more modern instrumental conception of literacy concerned with providing individuals with the skills to fulfill their political or economic function in society. ${ }^{96}$ Many of these readers would have been taught to read primarily as a spiritual exercise.

Not surprisingly, readers who were not members of the elite classes were more likely to hold religious literature in their hands because often, their access to books depended on the tutelage or sponsorship of ecclesiastics. Some priests shared their books with their close friends or penitent parishioners. ${ }^{97}$ Repeated warnings from inspectors of the Colegio de San Pablo noted friars' common practice of lending out books to lay friends. ${ }^{98}$ The publication of cheap editions of books of hours and prayers also facilitated

centralización de los sistemas educativos nacionales," The Hispanic American Historical Review, Vol. 71, No. 2 (May, 1991): 357.

${ }^{95}$ The first figure is from Pablo Macera, "Noticias sobre la enseñanza elemental en el Perú durante el coloniaje" in Macera, Pablo, Trabajos de historia (Lima: instiutio nacional de cultura, 1977), 258. The second can be found in Cristóbal Aljovín de Losada, Caudillos y constituciones (Perú, 1821-1845 (Lima: Instituto Riva-Agüero, Fondo de Cultura Económica, 2000). Both are mentioned in Jose Ragas, "Leer, escribir, votar. Literacidad y cultura política en el Perú (1810-1900),” 115.

${ }^{96}$ Robert Darnton, "First Steps Toward a History of Reading," 16 and Dorinda Outram, The Enlightenment: New Approaches to European History, $2^{\text {nd }}$ ed. (Cambridge University Press, 2005), 15.

${ }^{97}$ Nancy E. Van Deusen, “El cuerpo como libro viviente (Lima, 1600-1640)” Histórica XXXI.1 (2007): 27.

${ }^{98}$ Luis Martín, The Intellectual Conquest of Peru, 82. 
the circulation of some religious literature among popular groups. ${ }^{99}$ Even a poor mulatto woman managed to compile a small library of seventeen devotional books. ${ }^{100}$ Oral culture and manuscript copies of texts exposed plebeians to portions of novels as well as poetry, fables, songs, and other forms of recreational literature. Nevertheless, for most colonial non-elites, the "readable space" and "actualization" of texts remained circumscribed by an ecclesiastical authority or an orator. ${ }^{101}$

The Late Eighteenth Century and the New Functions of Reading

The eighteenth century marked a period of growth in the production of European books and other printed materials, which also reached Spanish-American markets. Historian Rolf Engelsing argued the sharp increase in reading materials - and the more "extensive" as opposed to "intensive" reading of these materials — constituted a "reading revolution" in Europe. ${ }^{102}$ While people had previously read a small number of texts several times, they were now reading several works once and quickly moving on to another. Moreover, more people began to read silently and privately. The publication of a wide

\footnotetext{
${ }^{99}$ Pedro Guibovich, Censura, libros e Inquisición en el Perú colonial, 1570-1754 (Sevilla: Consejo Superior de Investigaciones Científicas, Escuela de Estudios Hispano-Americanos, Universidad de Sevilla, Diputación de Sevilla, 2003), 206.

${ }^{100}$ Van Deusen describes the case of Estephanía de San Joseph in op. cited work "El cuerpo como libro viviente (Lima, 1600-1640), 27. Other unlikely cases discussed in Teodoro Hampe Martínez, Bibliotecas privadas en el mundo colonial: la difusión de libros e ideas en el virreinato del Perú, siglos XVI-XVII (Frankfurt am Main: Vervuert, 1996). They include the library of a vagabond, a kuraka and a provincial priest.

101 The concept of readable space addresses the text in its material and discursive form while actualization refers to a reading, its concrete practices and interpretative procedures. See Michel de Certeau quoted in Roger Chartier, "Laborers and Voyagers: From the Text to the Reader," Diacritics, 22.2 (Summer, 1992): 49-61.

${ }^{102}$ See his work discussed in op. cited by Dorinda Outram, The Enlightenment, 16.
} 
range of periodicals, novels, pamphlets, children's books, works of travel and natural history, and the appearance of new establishments that provided cheaper physical access to such materials facilitated this transformation in reading culture. While historians have questioned Engelsing's unilineal and simplistic model noting that intensive reading continued in some circles, they generally agree that the late eighteenth century was a turning point when "more reading material of a more varied character was eagerly seized upon by a broader reading public than ever before."103

As more people read and reading materials diversified, spaces of sociability such as salons, scientific academies, reading circles, Masonic lodges and coffee houses emerged to meet the demands of a new reading public, a process that fostered discussion and critical debate in urban literate enclaves across Europe. The proliferation of critical debate within new printed media and spaces of sociability constituted what Jürgen Habermas described as the "public sphere" or a realm relatively autonomous of state control where public opinion began to take form and exert influence on public policy. ${ }^{104}$ In this evolving cultural landscape, some of the most important political events of the eighteenth century-the Seven Year's War (1756); the expulsion of the Jesuits from Portugal in 1769, France in 1764, and Spain in 1767; the imposition of the intendancy system in 1786; and the

\footnotetext{
${ }^{103}$ See op. cited works by Dorinda Outram and Robert Darnton in footnote 38.

${ }^{104}$ Jürgen, Habermas, The Structural Transformation of the Public Sphere: An Inquiry into a Category of Bourgeois Society (The MIT Press, 1991), 27.
} 
American (1775) and French (1789) revolutions, among other events-prompted the publication of accompanying literature, which also reached the New World. ${ }^{105}$

For European monarchs, works by some Enlightenment thinkers were especially problematic for their political and subversive content. ${ }^{106}$ The most abundant legislation regarding prohibited books corresponded to the period between the second half of the eighteenth century and early part of the nineteenth century. Increased royal and ecclesiastical censorship, however, failed to curtail reading practices among elites. In 1785, a Spanish official noted that prohibited works of Montesquieu, Linguet, Raynal, Machiavelli, Monsieur Le Gros, and several encyclopedias were circulating freely in Peru. ${ }^{107}$ Per some accounts, banned books entered Lima under the very noses of port authorities who were only charged with reviewing publishing information for the purpose of applying import taxes. Inquisitors allowed the books to be delivered to the private residences or businesses of the addressees where boxes were supposed to remain closed awaiting their examination. Viceroy Teodoro de Croix, argued that owners took advantage of this time and replaced banned books with sanctioned ones. ${ }^{108}$ Meanwhile, inquisitors maintained that a Holy Office representative inspected the books in Cadiz and therefore, the contraband came from travelers who carried the books in their luggage. ${ }^{109}$

\footnotetext{
${ }^{105}$ José Abel Ramos Soriano, "El 'santo oficio' de los calificadores de libros en la Nueva España del siglo XVIII," 188-191 and op. cited work by Uribe Uran, "The Birth of the Public Sphere in Latin America during the Age of Revolution."

${ }^{106}$ Guibovich, "La literatura francesa en el virreinato del Perú,” 92-93.

${ }^{107}$ Ibid, 101.

${ }^{108}$ Ibid, 102

${ }^{109}$ Ibid, 101-103.
} 
Even as Bourbon monarchs increased censorship of literature they considered dangerous, they hoped to strike a balance by promoting the publication of some periodicals, liberalizing some laws to stimulate a sanctioned book trade and supporting some initiatives to propagate the arts and sciences. ${ }^{110}$ To be sure, in Lima, Juan Antonio Suardo had pioneered efforts to inform of daily occurrences in the city through his handwritten periodical Diario de Lima (1629-1634). However, not until the second half of the eighteenth century did regularly printed periodicals begin to circulate. The official Gaceta de Lima, appeared sporadically from 1756 through $1798 .{ }^{111}$ The Gaceta's early issues focused on local news and events, although its latter editions more often reprinted articles from Madrid's journals which described notable political and social events in the European courts. ${ }^{112}$ The influence of the Enlightenment prompted intellectuals across the Atlantic World to produce reading material with more regularity. ${ }^{113}$ In 1792, Hipólito Unanue, Toribio Rodríguez de Mendoza, Ambrosio Cerdán de Landa, José Baquijano Carrillo, Jacinto Calero Moreira and many other intellectuals formed the Sociedad Amantes del País

\footnotetext{
${ }^{110}$ Ibid, 92-93.

111 Tedoro Hampe Martínez, "Bibliotecas, imprentas y difusión de noticias en el Perú colonial," Bulletin Hispanique (2011), 422.

112 Víctor Peralta Ruiz, "Prensa y opinion palaciega. La Gaceta de Lima de Villagarcía a Superunda (17441751)" Histórica XXXI.1 (2007), 83 and Hampe Martínez, "Bibliotecas," 422. Also see Tamar Herzog, "La Gaceta de Lima (1756-1761): la reestruturación de la realidad y sus funciones," Histórica, vol. 16, No. 1 (1992): 33-61.

${ }^{113}$ Pedro Guibovich, "Alcances y límites de un proyecto ilustrado: la Sociedad de Amantes del País y el Mercurio Peruano," Historica XXIX.2 (2005), 56. For a comparative view on Spanish America, see Victor Uribe-Uran, "The Birth of the Public Sphere in Latin America during the Age of Revolution," Comparative Studies in Society and History, Vol. 42, No. 2 (Apr., 2000): 425-457. On the early periodical press in Europe see Deena Goodman, The Republic of Letters: A Cultural History of the Enlightenment (Ithaca and London: Cornell University Press, 1994), 165-175 and Martyn Lyons, A History of Reading and Writing (New York: Palgrave Macmillan, 2010), 123.
} 
in order to gain support for their periodical Mercurio Peruano (1791-1794). The prospectus noted a local need for information about Peru, its commerce, agriculture, industry, and culture as well as for news from abroad. The founders hoped to inform on the current events in Peru and "enlighten" (ilustrar) readers on the subjects of history, science, and literature. ${ }^{114}$ The newspaper's support of Bourbon political, social and economic reforms allowed the editors of the newspaper to operate with the approval of viceroy Francisco Gil de Taboada and ultimately, reach four-hundred subscribers. ${ }^{115}$ With his subscription, the viceroy also supported the Diario de Lima (1791-1793), which offered commercial advertisements, news, and some short historical and scientific articles. ${ }^{116}$ Lima's elites discussed the content of these newspapers in the growing number of cafes and literary circles, which marked an incipient transformation in Lima's reading culture and the emergence of a public sphere. ${ }^{117}$

Benedictine and Jesuit scholars took special interest in the earlier works of Newton, Descartes, and Bacon, which helped promote new ideas about learning methods, early education, and the functions of reading among literate circles in Lima. The seventeenthcentury scientific revolution, its emphasis on experience, empiricism, nature, and the use of the senses in learning processes had already influenced the pedagogical thought of Moravian educator John Amos Comenius (1592-1670) and John Locke (1632-1704) who

\footnotetext{
${ }^{114}$ Ibid, 53-54.

${ }^{115}$ Ibid, 65. On the number of subscribers see Víctor Peralta, "La revolución silenciada. Hábitos de lectura y pedagogía política en el Perú, 1790-1814,” Anuario de Estudios Americanos, 54, no. 1 (1997), 111.

116 Raúl Porras Barrenechea, “130 años de periódicos (1791-1921)” Mundial (1921).

${ }^{117}$ Peralta, "La revolución silenciada," 108. Also see Victor Uribe-Uran, "The Birth of the Public Sphere," 425-457.
} 
laid the foundations of modern pedagogy. They centered educational methods around the individual needs of the child, sensory experience, reason, and the use of teaching aids, criticized rote memorization, and rejected physical punishment. ${ }^{118}$ In Lima, some priests took up Bacon's experimental method in the sciences and called for a purge of excesses of scholasticism, which privileged dialectical reasoning and the use of authoritative texts in teaching methods. ${ }^{119}$ Influenced by these ideas, Jesuit priest Esteban de Orellana published Introducción a la Lengua Latina. He argued that teachers needed to stimulate children by exciting their curiosity. Importantly, he believed that teachers should not posit too many questions, but should cleverly induce children into constructing their own. Additionally, he recommended that they treat children tenderly, praise their efforts, reward their correct answers, and forgive erroneous responses numerous times. ${ }^{120}$

As Jesuit educators began making changes to their teaching methods and curricula, Charles III moved to secularize education as part of his broader plans of centralizing power and enriching his coffers. He expelled the Jesuit order from Spain and its colonies in 1767, confiscated their properties, and closed their numerous schools. The crown later reestablished a fraction of the Jesuit institutions as state-run schools and ordered the foundation of other secular schools. ${ }^{121}$ The ideas of philosopher and advisor to the king

\footnotetext{
${ }^{118}$ For an overview of notable pedagogues see Robert R. Rusk and James Scotland, Doctrines of the Great Educators (New York: St. Martin's Press, 1979).

119 Tanck de Estrada, "El siglo de las luces," 119; Guibovich, "La literatura francesa en el virreinato del Perú," 89.

${ }^{120}$ Esteban de Orellana, Instrucción de la Lengua Latina o Arte de adquirirla por la traducción de los autores (Lima: En la Oficina de los Niños Expósitos, 1759), 23. Also see Premo's discussion in Children of the Father King, 147.

${ }^{121}$ According to Dorothy Tanck de Estrada, the crown reestablished less than half of the Jesuit schools and a good portion of the funds from the sale of Jesuit-owned properties was sent to Spain producing a
} 
Gaspar Melchor de Jovellanos undergirded Bourbon efforts to secularize education. For Jovellanos, the primary object of the government was to foment agriculture, industry, commerce, and naval power, which he considered the main sources of private wealth and public revenue (renta pública). ${ }^{122} \mathrm{He}$ viewed the creation of a system of public education in charge of forming industrious and knowledgeable subjects as the most efficient way of attaining such prosperity. He recommended the creation of a governmental body (junta de instrucción pública) for the development of methods and curricula, and supervision of public schools. ${ }^{123}$

Jovellanos emphasized the importance of alphabetic and algebraic literacy for the new system of education, which he labeled educación literaria. ${ }^{124}$ Schools of "first letters" (primeras letras) constituted the first phase of educación literaria. In these schools, he envisioned individuals from all the classes of the state learning the basic methods (reading, writing, arithmetic) for attaining knowledge and skills. While Spanish teachers had long viewed reading as an auxiliary tool for learning about religion, Jovellanos saw it as a stepping stone for pupils to learn more about their future occupations. Although he was critical about traditional emphasis on religion, he believed this subject, as well as civics and morality —adapted to the abilities of children—needed to be taught concurrently with

\footnotetext{
"decapitalization" of education; see her op. cited work "El siglo de las luces," 120. On some of the schools established in Peru, see Bianca Premo, 143-178.

${ }^{122}$ Gaspar Melchor de Jovellanos, "Memoria sobre educación pública ó sea tratado teórico-práctico de enseñanza, con aplicaci'on á las escuelas y colegios de niños" in Obras publicadas e inéditas de D. Gaspar Melchor de Jovellanos, ed. by Cándido Nocedal (Madrid: M. Rivadeneyra, 1858), 238.

${ }^{123}$ Gaspar Melchor de Jovellanos, "Bases para la formacion de un plan general de instrucción" in op. cited Obras publicadas e inéditas de D. Gaspar Melchor de Jovellanos, 268.

${ }^{124}$ Ibid, 269.
} 
reading and writing. His modernized curriculum for primary schools also prescribed the inclusion of lessons in drawing for their utility to different arts and crafts. ${ }^{125}$

The Napoleonic Wars, the forced abdication of Charles IV and Ferdinand VII, and the Spanish-American wars of independence interrupted the Bourbon educational project, but evolving views on the function of reading as well as Jovellanos' influential ideas on the role of the state in education served as the basis for subsequent legislation in Spain and its former colonies. ${ }^{126}$ Spain's liberal constitution of 1812 required primary schools be established in all towns and made municipal governments (ayuntamientos) responsible for their funding. In an effort to homogenize educational content, it ordered the creation of the Dirección General de Estudios, a government body charged with inspecting public schools. The constitution also set forth a uniform curriculum for primary schools, which included reading, writing, religion, and civics. University and other establishments of advanced education needed to provide instruction on Spain's political constitution. ${ }^{127}$ Spain's 1821 educational code noted that although private schools had more liberties in implementing curriculum and method, they still needed to observe the rules of "Spanish Christian political civility" or (buena policía) and refrain from teaching doctrines contrary to Catholic religion or subversive to the Spanish constitution. ${ }^{128}$ The code also addressed the

\footnotetext{
${ }^{125}$ Ibid, 242.

${ }^{126}$ Tanck Estrada, "La Cortes de Cádiz y el desarrollo de la educación en México," Historia Mexicana, Vol. 29, No. 1, Ensayos sobre la historia de la educación en México II (1979) : 3-34.

127 Constitución Política de la Monarquía Española. Promulgada en Cádiz 19 de Marzo de 1812 (Cádiz: Imprenta Real, 1812).

${ }^{128}$ Reglamento General de Instrucción Pública Decretado por las Cortes en 29 de Junio de 1821 (Coruña: Imprenta de Arza, 1821), 3. "Buena policía" is described in Premo, Children of the Father King, 93.
} 
circulation of educational works. It required that the Dirección General de Estudios take an active role in the formulation and publication of rudimentary books, and ordered that secondary and special schools form libraries for the use of their students.

The Peruvian Constitution of 1823 and subsequent decrees mirrored Spanish educational provisions that enhanced the role of government in promoting education and codified a new civic stimulus for reading. ${ }^{129}$ The Constitution called for the establishment of primary schools in the "smallest of places" and required that they include instruction on religion and the moral and civic obligations of individuals. It also charged a central governmental body with the inspection of primary schools. ${ }^{130}$ Alphabetic literacy would function as a gateway for exercising citizenship rights within the new republican regime. According to article 17 , only Peruvians with the ability to read and write would be considered citizens after the year 1840 . The subsequent constitutions of 1828 and 1834 ordered the creation of a broad educational code, but this decree remained unfulfilled until $1850 .{ }^{131}$

\footnotetext{
129 "Constitución Política de la República Peruana Sancionada por el Primer Congreso Constituyente el 12 de Noviembre de 1823," November 12, 1823, ADLP. Early decrees that regulated education included the "Decreto reglamentando las escuelas Lancasterianas," November 9, 1826; "Circular disponendo la erección de escuelas Lancasterianas November 11, 1826; "Decreto determinando las materias que deben enseñarse en las escuelas gratuitas de la capital de Lima," November 18, 1833; "Decreto arreglando la instrucción primaria de la capital," November 13, 1833; and "Decreto reglamentando las escuelas," November 28, 1836 in Juan Oviedo, Colección de Leyes, Decretos y Ordenes publicadas en el Perú desde el año 1821 hasta 31 de diciembre de 1859, Tomo IV: Ministerio de Beneficencia, Instrucción y Justicia (Lima: Felipe Bailly, 1862).

130 “Constitución Política de la República Peruana Sancionada por el Primer Congreso Constituyente el 12 de Noviembre de 1823," November 12, 1823 (ADLP).

${ }^{131}$ Constitución Política de la República Peruana 1828, March 18, 1828, ADLP; Constitución Política de la República Peruana Dada por la Convención Nacional el día 10 de Junio de 1834, June 10, 1834, ADLP.
} 
In the meantime, legislators issued a series of decrees, setting their hopes on Joseph Lancaster and Andrew Bell's "revolutionary" system of education, which they believed would nearly eradicate illiteracy. ${ }^{132}$ A decree from 1822, signed by one of San Martín's chargés in Lima, Argentine reactionary Bernardo Monteagudo, embodies political elites' unflinching belief in this system:

It is still not possible to foresee the revolution that [the Lancasterian method] will generate in the world. When the use of the mutual method [of teaching] has been generalized in all civilized nations, the empire of ignorance will cease to exist, or at the very least, it will be reduced to its limits, which it will no longer trespass. ${ }^{133}$

The method offered several advantages for schools with poor funding and teaching materials. It recommended the use of advanced students as teaching assistants or "monitors," making it possible for one teacher to direct the learning of large groups of students. Instead of using individual reading books, which could only be used by one child at a time, the system recommended that schools print singular pages in a size three times of the original. The pages would then be attached to pasteboards and placed on walls in the order of difficulty of the lesson on the page. ${ }^{134}$ It prescribed the use of sandboxes, slates,

\footnotetext{
${ }^{132}$ As early as 1822, legislators emphasized the goal of instituting Lancaster's methods in primary schools. See "Disponiendo que se establezca en Lima una escuela normal central," July 6, 1822, and "Disponiendo que haya escuelas primarias gratuitas en todos los conventos de Regulares," February 23, 1822 in op. cited Juan Oviedo, Colección de Leyes, Decretos y Ordenes publicadas en el Perú desde el año 1821 hasta 31 de diciembre de 1859.

133 "Disponiendo que se establezca en Lima una escuela normal central." Original text: "aun no es posible calcular la revolucion que va á causar en el mundo, el método de la enseñanza mútua, cuando acabe de generalizarse en todos los pueblos civilizados; el imperio de la ignorancia acabará del todo, ó al menos quedará reducido á unos limites, que no vuelva jamas á traspasar."

${ }^{134}$ Joseph Lancaster, Improvements in education as it respects the industrious classes of the community (London: J. Lancaster, 1806), 55-56.
} 
and slate pencils for the first stages of reading and writing instruction. According to the method, only advanced students had the option to use more expensive paper and ink. ${ }^{135}$ An 1829 article from the official newspaper, Mercurio Peruano, highlighted how a school in Lima ascribed to the method, describing a busy scene with children reading arithmetic problems in one corner of a classroom while others read pages with lessons on commercial book keeping and urban civility in another corner. ${ }^{136}$

Decrees addressing curricular matters reveal an emphasis on a more democratic model of reading. The democratic model of reading involved disseminating educational materials to help the propagation of alphabetic literacy and applying reading to subjects beyond religion. Even as Peruvian legislators sought to promote cost-saving ideas and implement a more efficient use of print through the Lancasterian system, they hoped to improve access to actual reading materials. In 1836, a decree assigned a printing press specifically for the needs of primary and grammar schools (aulas de latinidad). It singled out the importance of printing lessons in religion, orthology (ortolojia), calligraphy, and arithmetic, subjects officially assigned to Lima's primary schools in $1833 .^{137}$ The decree required that the government distribute copies of the lessons throughout Lima and the rest

\footnotetext{
${ }^{135}$ Different versions and adaptations of Lancaster's short manual circulated in Lima and beyond. For instance, one manual adopted the Lancasterian method for teaching girls how to sew, see Manual para el método de enseñar la costura en las escuelas lancasterianas de niñas de la República del Perú, adoptado del que se usa en las escuelas elementales de Inglaterra (Lima: Imprenta de la Instrucción primaria, 1827). A Spanish version of the manual was printed in a northern province of Peru, see Manual por el método Lancaster para la instrucción primaria (Huaraz: Imprenta del Colejio de la Libertad, 1848). For a broad view of the adoption of the Lancasterian method in Spanish America see Eugenia Roldán Vera, "“Order in the classroom': The Spanish American Appropriation of the Monitorial System of Education," Paedagogica Historica 41, 6 (2005): 655-75.

136 “Instrucción Primaria," Mercurio Peruano (Lima), November 17, 1829.

137 "Decreto determinando las materias que deben ensenarse en las escuelas gratuitas de la capital de Lima, November 18, 1833 in Oviedo, Colleccion de Leyes, 18.
} 
of the country. ${ }^{138}$ Although parents were required to provide their children with the assigned school books, legislators hoped to provide poor students the option of free access to printed materials.

Early decrees, however, ordered that printing presses produce "good compilations" (buenos compendios) of European texts on Spanish and Latin grammar, religious and secular history, and excerpts of Latin classics. ${ }^{139}$ The emphasis on printing compilations, religious and secular history (a term used for universal history, rather than Peruvian history), and excerpts of Latin classics reveals a continued Eurocentric emphasis on the curriculum. Moreover, civic instruction failed to appear in these decrees.

Books, Newspapers, and the "Market of Simplified Enlightenment"

With the declaration of freedom of the press by the Spanish Cortes in 1810 and by subsequent Peruvian constitutions, early nineteenth-century limeños did gain access to more diverse literature. Some of this literature, especially the periodical press published exclusively political content; however, rather than promote Peruvian nationalism, these newspapers emphasized anti-Spanish rhetoric. An analysis of other literature available in Lima's miscellaneous stores further reveals that books, novels, and other reading materials came overwhelmingly from European countries.

\footnotetext{
138 “Reglamento de escuelas," November 28, 1836 in Juan Oviedo, Colección de Leyes, Decretos y Ordenes publicadas en el Perú desde el año 1821 hasta 31 de diciembre de 1859, 161.

139 "Determinando las materias que deben ensenarse en las escuelas gratuitas de la capital de Lima," November 18, 1833 in Juan Oviedo, Colección de Leyes, Decretos y Ordenes publicadas en el Perú desde el año 1821 hasta 31 de diciembre de 1859, 18.
} 
During the early decades of the nineteenth century an active political periodical press emerged with newspapers like El Peruano (1811) and El Satélite del Peruano (1812). These newspapers tried to teach their readers about their civil rights and pit them against the "despotism" of Spanish authorities. ${ }^{140}$ Even though these periodicals were quickly suppressed after Ferdinand VII returned to power and abolished the liberal Spanish Constitution of 1812 , they became the first newspapers to counter reading materials sponsored by Spanish authorities. Independence from Spain and the reinstitution of freedom of the press stimulated the publication of mostly political newspapers during Peru's early republic (see Table 1). According to contemporary statistician Manuel Atanasio Fuentes, nearly 65 percent of 128 newspapers published in Lima between 1821 and 1858 could be categorized as political newspapers. ${ }^{141}$ He categorized 12 percent of the periodicals as literary newspapers and 9 percent as a mixed genre of politics and literature. An additional 9 percent focused on commerce and about 8 percent of the newspapers were categorized under "Religious Matters," "Medicine," "Judicial," and "Costumbres."142

\footnotetext{
${ }^{140}$ Peralta, "La revolución silenciada," 107.

${ }^{141}$ Manuel Atanasio Fuentes, Estadística General de Lima (Lima: Tip. Nacional de M. N. Corpancho, 1858), 283.

${ }^{142}$ Ibid. The category of "Costumbres" represented the popular nineteenth-century literary genre which shared elements of romanticism and realism. The genre included short stories and commentary about local customs, practices, and folklore.
} 
Table 1. Types of Newspapers Published in Lima, 1821- 1858

\begin{tabular}{|l|l|}
\hline Emphasis of Newspaper & Number of Newspapers \\
\hline Political & 83 \\
\hline Literature & 15 \\
\hline Literature and Politics & 10 \\
\hline Commerce & 10 \\
\hline Medicine & 3 \\
\hline Religious Matters & 3 \\
\hline Judicial affairs & 2 \\
\hline Costumbres (Culture) & 2 \\
\hline Total & 128 \\
\hline
\end{tabular}

Source: Manuel Atanasio Fuentes, Estadística General de Lima (Lima: Tip. Nacional de M. N. Corpancho, 1858), 283.

To address demand for less political newspapers, book merchants imported European literary periodicals and administered subscriptions through their establishments. British publisher Rudolph Ackermann, who also became involved in exporting a broad range of Spanish books and catechisms to Mexico and South America, also published several periodicals that became available through Lima's bookstores. They included Correo Literario y Político de Londres (1826) and Museo Universal de Ciencias y Artes (1824-6), sold at the Librería de García. ${ }^{143}$ Correo Literario mainly published literary pieces while Museo Universal focused its articles on science and technology. ${ }^{144} \mathrm{El}$ Instructor (1834-41) and its continuation, La Colmena (1842-5), published after Ackermann's death, were available in Lima at the Tienda del Tigre. ${ }^{145}$ They included a

\footnotetext{
143 “Catálogo de las obras españolas, publicadas por el Señor Ackermann,” Mercurio Peruano, March 22, 1831.

${ }^{144}$ Roldán Vera, The British Book Trade and Spanish American Independence, 53.

145 “Números 6, 7, y 8 de la Colmena, continuación del Instructor, con muchas laminas," El Comercio, June 26, 1844.
} 
wide range of articles covering literary arts, geography, technology, political economy and fashions. The preface to the first volume of El Instructor noted that the "nature" of the periodical was that of a "cyclopedia" for it embraced "a great extension of the natural sciences." Moreover, the editors emphasized its content was completely "suited for popular instruction," and where they deemed necessary, "adapted it to the tastes" of readers. ${ }^{146}$ The lengthy print run of over a decade of El Instructor and La Colmena and their distribution in various Spanish American countries attests to the demand for instructional literature that emerged after independence.

Some local literary and educational magazines appeared in Lima to cater to a readership seeking instruction on literature, natural sciences, and education. Like their colonial predecessor Mercurio Peruano, and Ackermann's El Instructor and La Colmena, several republican periodicals published a broad range of educational pieces on the various arts and sciences. El Instructor peruano ó gabinete de literatura y ciencias naturales (Lima, 1841), El Instructor Peruano (Lima, 1847), and Instructor Popular (Cuzco, 1858) used their titles to allude to their educational mission. The titles of the periodicals reflected the belief in the power of the periodical press in disseminating and directing knowledge through targeting popular groups. In addition to instructional articles, they also printed news, documents, and recreational literature. ${ }^{147}$

\footnotetext{
${ }^{146}$ El Instructor ó Repertorio de Historia, Bellas Letras y Artes, Tomo I (London: Ackermann y Compañía, 1834). Original text: "La naturaleza de nuestro Instructor es la de una cyclopedia, pues aunque los asuntos no van aquí ordenados alfabéticamente, abrazan una grande estension de las ciencias naturales...Los asuntos de que hemos tratado hasta aquí, y que se continuarán en adelante, son de varias especies, todos adecuados á la instrucción popular, y adaptados, en cuanto nos ha parecido mejor, al gusto de nuestros Lectores."

${ }^{147}$ Most of these newspapers did not survive, but Mariano Felipe Paz Soldán described their content in Biblioteca peruana (Lima: Imprenta Liberal, 1879), 35.
} 
Lima's book trade, however, relied almost exclusively on the sale of European books. Changing notions of the functions of alphabetic and algebraic literacy created a demand for educational materials stimulating European book imports. As discussed above, Jovellanos had influenced Bourbon educational reform by calling for the secularization of schools and the expansion of education, calls which republican leaders echoed after Independence. Expanding education also became a source of legitimacy for new representative regimes given the role of citizens in constructing a civil order where national sovereignty rested on the people. The development of some economic sectors also created private demand for more people with reading and writing abilities. ${ }^{148}$ Moreover, constitutional provisions guaranteeing freedom of the press also stimulated the book market since they abolished colonial-era prohibitions on book imports and privileges that restricted printing to a handful of licensees. ${ }^{149}$ During this time, however, Lima had a very limited press industry. The only printing house in Lima belonged to José Masías, but he only printed "light" works from his establishment and could not meet the growing demand. ${ }^{150}$ Less than five percent of the overall books published in Lima between 1821 and 1858 could be categorized as educational books. ${ }^{151}$ European works thus fulfilled most of the demand for educational materials.

\footnotetext{
${ }^{148}$ Tanck Estrada, "La enseñanza de la lectura y de la escritura en la Nueva España," 26.

${ }^{149}$ This protection was only extended to works not dealing directly with religion. See "Constitución Política de la República Peruana Sancionada por el Primer Congreso Constituyente el 12 de Noviembre de 1823;" "Declarando innecesaria la censura previa para el uso de la imprenta," October 13, 1821; "Reglamento de imprenta," November 3, 1823; ADLP.

${ }^{150}$ Fuentes, Manuel Atanasio, Estadística General de Lima (Lima, 1858), 282-84.

${ }^{151}$ Ibid, 184.
} 
The Librería de García, which operated in 1831, advertised the numerous translations and abridged works of bookseller Rudolph Ackermann. ${ }^{152}$ In addition to his periodicals, mentioned above, the publisher along with several Spanish exiles had embarked on a project of translating and publishing educational manuals during the 1820s. Many of these materials came in catechistic or question-and-answer format, which complemented the Lancasterian system of education by providing teacher assistants with streamlined dialogues to use with less advanced students. ${ }^{153}$ Ackermann's publishing house edited nearly 100 titles in Spanish. They included four magazines and twenty-five catechisms of various subjects in the arts and sciences, and additional didactic books, novels, and political treatises (see Table 2). ${ }^{154}$ Like D'Alambert, Diderot, and other eighteenth-century philosophers did before him with their Encyclopedie, Ackermann sought to bring practical knowledge, but for a Spanish-speaking audience. Indeed, his books reached schools in Lima, Buenos Aries, and Santiago. ${ }^{155}$ Some of the same men involved in Ackermann's project later established the "Biblioteca Hispano-Americana," which similarly translated and abridged a variety of manuals during the $1850 \mathrm{~s} .{ }^{156}$

\footnotetext{
152 "Catalogo de las Obras Españolas, publicadas por el Señor Ackermann, Que se hallan en la librería de García, calle de Mercaderes núm. 5.," Mercurio Peruano, March 22, 1831.

${ }^{153}$ See Eugenia Roldan Vera, The British Book Trade and Spanish American Independence: Education and Knowledge Transmission in Transcontinental Perspective (Routledge, 2017).

${ }^{154}$ Roldan Vera, "Reading in Questions and Answers: The Catechism as an Educational Genre in Early Independent Spanish America," 19.

155 See Eugenia Roldan Vera, "Reading in Questions and Answers: The Catechism as an Educational Genre in Early Independent Spanish America,” Book History, Volume 4, 2001, 17-48.

156 The titles in the collection can be found within the pages of its various volumes. See for instance, Baldomero Menéndez, Manual de geografía y estadística del Perú (París: Libr. De Roca y Bouret, 1861.
} 
Table 2. Ackermann's Catechisms, 1824-1828

\begin{tabular}{|l|l|}
\hline Author & Title \\
\hline & Catecismo del Bajo Imperio \\
\hline & Catecismo de gramática casellana \\
\hline & Catecismo de historia Grecia \\
\hline & Catecismo de historia de los imperios antiguos \\
\hline & $\begin{array}{l}\text { Catecismo de historia moderna. Parte I: Desde Carlo Magno } \\
\text { hasta Carlos V (s.f.) }\end{array}$ \\
\hline & $\begin{array}{l}\text { Catecismo de historia moderna. Parte II Desde Carlos V hasta } \\
\text { la independencia de América }\end{array}$ \\
\hline & Catecismo de la historia romana \\
\hline & Catecismo de industria rural y doméstica \\
\hline Mora, José Joaquín de & Catecismo de música \\
\hline Mora, José Joaquín de & $\begin{array}{l}\text { Catecismo de geografía; o Introducción al conocimiento del } \\
\text { mundo y sus habitantes }\end{array}$ \\
\hline Mora, José Joaquín de & Gramática latina dispuesta en forma de catecismo \\
\hline Núñez de Arenas, José & Catecismo de álgebra \\
\hline Núñez de Arenas, José & Catecismo de ambas trigonometrías \\
\hline Núñez de Arenas, José & Catecismo de geografía, para uso de los Globos \\
\hline Núñez de Arenas, José & Catecismo de geometría elemental \\
\hline Núñez de Arenas, José & Catecismo de geometría práctica \\
\hline [Pastor Esteban] & Catecismo de agricultura \\
\hline Urcullu, José María de & Catecismo de aritmética comercial \\
\hline Urcullu, José María de & Catecismo de astronomía \\
\hline Urcullu, José María de & Catecismo de historia natural \\
\hline Urcullu, José María de & Catecismo de mitología \\
\hline Urcullu, José María de & Catecismo de retórica \\
\hline $\begin{array}{l}\text { Villanueva, Joaquín } \\
\text { Lorenzo }\end{array}$ & Catecismo de los literatos \\
\hline Villanueva, Joaquín & Catecismo de moral \\
\hline Lorenzo & Caurce: “ppendix 1" \\
\hline in Eugenia Ro dean Vera, The British Book Trade and Spanish \\
\hline
\end{tabular}

Source: "Appendix 1" in Eugenia Roldán Vera, The British Book Trade and Spanish American Independence: Education and Knowledge Transmission in Transcontinental Perspective (Ashgate, 2003), 239. These books were sold in Lima at Librería de García, see "Catalogo de las obras españolas publicadas por el Señor Ackermann, Que se hallan en la librería de García, calle de Mercaderes núm. 5," Mercurio Peruano, March 22, 1831.

Still, Ackermann's publications were scarce and failed to satisfy the demand for didactic works. The high cost of paper and daily wages in England where they were 
published prevented many people from purchasing them. ${ }^{157}$ The writer of an article, titled "About the book market in South America" and published in an 1829 issue of Mercurio Peruano, remarked "what is the point of reading where there is nothing to read? (De que sirve la lectura donde no hai que leer?). The writer insisted on the urgency of stimulating a book market with cheaper prices so that the lower classes could purchase books, bring them to the provinces, and spread the habit of reading. The writer admired Ackermann's enterprise and hoped that other businessmen would soon take up the publication of books of "useful knowledge." He favored agricultural tracts with simple methods to duplicate production. The writer also hoped that book merchants would promote texts with moralistic themes disguised under the "spell of ingenious narrations" as well as religious books to nurture the soul and correct the mistakes of deficient education. ${ }^{158}$

Lima's book merchants began advertising books in newspapers during the 1820 s, naming a variety of European titles within their libraries. Most advertisements corresponded to stores or printing houses rather than bricks-and-mortar, exclusive bookstores. The store (tienda) at Portal de Botoneros, for instance, advertised its "well supplied" library and specific titles including the Novísima Recopilación de las leyes, D. José Manuel Restrepo's Historia de la Revolución de la República de Colombia (published in Paris) and a recent translation of William Robertson's Historia de la America. ${ }^{159}$ At Imprenta de la Libertad, Lima's residents could also find Antonio de

\footnotetext{
157 “Del comercio de libros en la América del Sur,” Mercurio Peruano, May 4, 1829. ${ }^{158}$ Ibid.

159 “En la Tienda numero 22," Mercurio Peruano, March 11, 1828 and "Libros," Mercurio Peruano, January $21,1829$.
} 
Nebrija's grammar books among several legal works. ${ }^{160}$ The Librería de Bodegones also advertised Nebrija's books and added the bookstore had recently received a shipment of books from Europe. ${ }^{161}$

The availability of translations of European works like Robertson's Historia de la America had important implications for readers in Lima and Spanish America, more broadly. The book promoted degeneration theories that French naturalists had embraced since at least the mid-eighteenth century. They posited that the rugged, remote and extreme climate of the American continent had a negative impact on the mental qualities of humans. Comte de Buffon, Cornelius de Pauw, Abbé Raynal, William Robertson and others spread the notion that the American lands were unhealthy, keeping Amerindians in a primitive stage of social and mental development. ${ }^{162}$ De Pauw and Raynal believed such degeneration extended to European settlers in the Americas. Although these ideas were not accepted uncritically and the circulation of Robertson's book was likely limited to few readers, the general notion that the environment affected mental capacity spread through newspaper articles. One article discussing the subject stated about the environment that:

Its balance, constitutive principals, its level of severity, its purity, clarity, and unfortunate circumstances produce in us happiness or sadness, the correct or

\footnotetext{
160 “Impresos," Mercurio Peruano, November 21, 1828.

161 “Libreria,” Mercurio Peruano, December 30, 1828.

${ }^{162}$ For a more detailed account of these ideas and their reception in the New World, see CanizaresEsguerra, How to Write the History of the New World: Histories, Epistemologies, and Identities in the Eighteenth-Century Atlantic World (Stanford University Press, 2001).
} 
incorrect use of mental faculties, calmness or storm of its effects, health or disease, life or death. ${ }^{163}$

The racist portrayals of Americans based on degeneration theories were certainly not lost to a man who wrote to Mercurio Peruano in 1831 regarding the state of educational literature in Peru. ${ }^{164}$ The writer's repeated emphasis on his origins in the Peruvian highlands, together with his dexterity in writing, could be interpreted as a subtle critique of contemporary associations between environment and intellectual backwardness. Signing as "A Peruvian from the Mountains" (Un peruano de la Sierra), he expressed his disdain for European-educated Peruvians who came back "bigheaded" after studying in Europe and too up the translation of works by European authors. ${ }^{165}$ The writer was not impressed with the many compilations circulating in Peru and stated that anyone could compile people's work and appropriate it (Cualquiera compila retazos de producciones agenas, y tambien se las apropia). He preferred Peruvian teachers of the old guard over "speculative sages" (sabios de especulacion). For the letter writer, traditional teachers had taught students to seek knowledge in parchment notebooks while at the time of his writing, the same knowledge was being repackaged in "little binded books" (libritos de pasta) and sold at excessive prices. ${ }^{166}$ The self-proclaimed "poor hill-dweller" (pobre serrano) added that

\footnotetext{
163 See "Sobre la Temperatura," Mercurio Peruano, June 6, 1832. Original text: "Su equlibrio, sus principios constitutivos, su mayor ó menor gravedad, su pureza, diafanidad, y las circunstancias contrarias producen en nosotros la alegría ó la tristeza, el recto ó el errado uso de las facultades mentales, la calma ó la borrasca de los afectos, la salud o la enfermedad, la vida ó la muerte."

164 “Señores editores,” Mercurio Peruano, June 28, 1831.

${ }^{165}$ Ibid. Original text: "Es bien sabido que la Europa abunda de sabios, y que la América no carece absolutamente de este género. Mas también está demostrado que el paso de ida y vuelta por el Atlantico no constituye tales, aunque si suele regularmente hincharlos."

166 Ibid. Original text: "Nuestros maestros nos enseñaron á buscar la verdad con cuadernos de pergamino, y la misma disfrazada en libritos de pasta se nos quiere hoy vender muy cara. Los muchachos con el gasto
} 
it would be best to teach children in Latin and if possible in Greek, languages which he considered to be sources of "true wisdom" (verdadera sabiduria). In addition to a reaction to the materiality, quality, and price of the books, the complaint reflected skepticism of evolving European teaching methods and a defense of traditional scholastic teaching. Proliferating abridged books translated into different languages posed an assault on teaching based on the close reading of authoritative texts in their original languages.

It is unclear whether the writer had indigenous, European or mixed ancestry since the term "serrano" only became a euphemism for "Indian" in the second half of the nineteenth century. ${ }^{167}$ The author, however, embraced his "serrano culture," associating it with traditional learning, which he believed to be more efficient than the "enlightened" and urban projects of those Peruvians educated abroad. Advertisements of modern teaching methods, he believed, merely distracted Peru's youth with chimerical promises of streamlined learning. He ended the letter with a series of statements about the author's son, which allegorized his disdain for the bustling "market of simplified Enlightenment" (tráfico de ilustración simplificada):

Tengo un hijo aprendiendo á escribir y gramática, y son muchas las veces que ha tratado interrumpir su carrera por el maldito tráfico de ilustración simplificada. Unas veces me ha dicho taita yo no quiero escribir porque van á venir de Francia unas plumas que ellas solas forman letras. Otras, taita mejor aguardaré la venida de un maestro que se ha anunciado, y que enseña á escribir con unas cifras muy simples, que cada una importa una oración entera. Otras, taita dicen que no es necesario estudiar Gramática, y que sin ella se va á ensenar cuanto hay en el mundo. Por último llegó á decirme que corria la notica del

de solo medio veian antes juegos de manos. Ahora se les da el nombre de Fisica recreativa, y vengan dos reales."

${ }^{167}$ In the twentieth century, "serrano" also became widely used as a derogatory term. See Cecilia Méndez, "De indio a serrano: nociones de raza y geografía en el Perú (siglos XVIII-XXI)" in Histórica, XXXV.1 (2011), 76- 88. 
arribo de un sabio al Callao, que prometia enseñar sin libros, y sin hablar siempre que el Estado lo dotase bien. Al oir esto lo apercibí seriamente á que no hiciese caso de novadores importunos y a que siguiese curzando con el maestro que fue mio. ${ }^{168}$

Based on other accounts, the practice of translating, editing and publishing European works deemed relevant for promoting popular education became widespread in early republican Peru as well as Spain and several of its former colonies. In 1832 for instance, government official from the southcentral city of Ayacucho A. Garrido published in Lima Principios generales de economía política. Garrido’s book was based on the work of French pedagogue Pierre-Henri Suzanne (1765-1837). ${ }^{169}$ In an advertisement, Garrido stated he had noticed that very few copies of Suzanne's work in the original French language circulated in Peru. Upon reading it, he concluded that Suzanne's clear prose placed the content within the reach of the "least enlightened in the subject," making his book a true catechism on political economy and the right cartilla for all children to learn how to read. ${ }^{170}$ Thus he took on the work of translating it to Spanish,

168 "Señores editores." The term "taita" or in some cases, "tata" is broadly used in Peru and other Latin American countries - particularly in rural areas - to refer to a father or "padre de familia." Some linguists have argued the term derived from native American languages like Guaraní in South America or Nahuatl in Mexico. Martha Hildebrant argues the term evolved from the Latin word "tata" and the Basque "aita" which both mean "father." See Martha Hildebrandt, El habla culta (o lo que debiera serlo) (Lima: 2010), 292-3. An alternative view denies the term has idiomatic specificity or that it evolved from any one or two languages since it belongs to a group of words that relate affective relationships and are produced through a simple and natural repetition of syllables in children's first efforts to articulate words. See Alexis Reto Agurto, "A nuestro padre, al viejito, al taita querido," June 15, 2012, UDEP, date accessed May 24, 2017, http://udep.edu.pe/castellanoactual/a-nuestro-padre-al-viejito-al-taita-querido/ and "Taita, Taitito," May 9, 2015, Taito, date accessed May 24, 2017, http://taitito.pe/index.php/puntos-de-vista/raul-zevallos/25puntos-de-vista/raul-zevallos/195-taitito.

${ }^{169}$ Garrido, A., Principios jenerales de economía política por P. H., traducidos libremente al español y aumentados con notas por A. Garrido, oficial mayor y tesorero interno de departamento de Ayacucho (Ayacucho: Imp. de B. Cárdenas, 1832).

170 “Variedades," Mercurio Peruano (Lima), March 21, 1833. 
adding notes, and making light corrections. Garrido advertised the book in Lima, announcing it was available in two of the capital's stores for 20 reales binded in goatskin (tafilete), and for 2 pesos stitched with flexible cardboard covers (á la rustica). ${ }^{171}$ The advertisement noted the prices were just above the cost of publication, but at 2 pesos or 16 reales, the most affordable option remained pricey for families headed by urban laborers. Generally earning 6 reales per day, laborers would have had to give up nearly 3 days of wages to provide their child with Garrido's book. ${ }^{172}$

Despite their prices, these translations and abridged works became popular enough to raise quality concerns among Lima's residents. ${ }^{173}$ The proliferation of these works was possible, in part, because until 1889, Peru had not entered any international copyright agreements, leaving foreign intellectual property unprotected unless it was explicitly edited and registered in Peru. ${ }^{174}$ Lima's Mercurio Peruano printed several commentaries criticizing the practice of translating works. One article-reprinted on Mercurio Peruano

\footnotetext{
${ }^{171}$ Ibid. During the first half of the nineteenth century, one peso generally equaled 8 reales, see Christine Hunefeldt, Liberalism in the Bedroom: Quarreling Spouses in Nineteenth-Century Lima (The Pennsylvania State University Press, 2000), XIX.

${ }^{172}$ According to Paul Gootenberg, day laborers generally earned 6 reales per day or jornal from Independence through approximately 1850, see Paul Gootenberg, "Carneros y Chuno: Price Levels in Nineteenth-Century Peru," The Hispanic American Historical Review, Vol. 70, No. 1 (Feb., 1990), 40. In the 1830s, one real or one sixth of a laborer's daily wages could buy a basket of bread with 5 pieces, see "En la panaderia de la Pescaderia," Mercurio Peruano, June 19, 1832.

${ }^{173}$ See "Señores editores," Mercurio Peruano, June 28, 1831 and "Sobre las traducciones," Mercurio Peruano, October 7, 1833.

${ }^{174}$ Although Peru's constitutions protected intellectual property, a law outlining the process for registering the property was not approved until 1849 . Authors needed to deposit a copy of the work at Lima's Biblioteca Nacional and an additional copy at the prefecture of the department where the item was edited. See "Determinando la curación de la propiedad de las obras intelectuales," November 3, 1849, ADLP. The Peruvian congress approved the "Tratado sobre propiedad literaria y artística" in 1889. See "Aprobando el tratado sobre propiedad Artística y Literaria celebrado en la ciudad de Montevideo," November 4, 1889, ADLP.
} 
from a Spanish writer-labeled the translations the "worst plague of the century" (es la mayor peste que ha inficionado nuestro siglo). ${ }^{175}$ According to the author, the practice was so pervasive that it would be uncommon to see a mother without a son already dedicated to translation (es desdichada la madre que no tiene un hijo traductor). ${ }^{176}$ The same writer of the 1829 article, "About the book market in South America," blamed the well-to-do for the problem of translations and the broader state of the book market in the Spanishspeaking world. ${ }^{177}$ It criticized the licentiousness of the rich classes-particularly in Mexico, Peru, and Colombia — where immoral and irreligious books became popular soon after colonial restrictions were lifted. The letter writer took issue with Spanish publishing houses that chose to go with cheap translators (verdaderos ganapanes de las letras). Eager copyists (copistas hambrientos), the letter writer continued, improperly translated legal and political works, grammar books, dictionaries, and elementary books, which formed a body of literature that was capable of "perverting the education of the most sensible and capable people." ${ }^{\prime 18}$

\section{Conclusion}

This chapter examined reading and print culture as well as educational ideas around the functions of reading over the course of the colonial and early republican periods. During

\footnotetext{
175 "Sobre las traducciones."

176 Ibid.

177 "Del comercio de libros en la América del Sur."

178 Ibid.
} 
the colonial period, plebeians had limited access to books. High illiteracy rates as well as crown and church restrictions on the circulation of books ensured their access to books was often circumscribed by a religious authority or an orator. For educators, teaching the rudiments of reading functioned as an aid for indoctrinating the masses. Elites, on the other hand, had greater access to advanced education and the financial ability to purchase novels and books about science and the arts.

The use of reading to support rote memorization of religious text came under scrutiny as educators across both sides of the Atlantic took interest in new learning methods that emphasized experience, the use of the senses, and the individual needs of the child. Jovellanos and early republican leaders advocated for the introduction in early education of a broader range of subjects including practical arts and civics. This democratic model of reading — of more people reading about more subjects_-became an essential component of the rhetoric of the new republican regime. Republican leaders passed legislation promising to expand education through the establishment of Lancasterian schools and to provide resources for the printing of educational materials. Changing notions about the functions of reading and demand for modern educational literature manifested in the proliferation of educational literature in Lima; however, as this chapter demonstrated through analysis of contemporary newspapers, advertisements, and data from contemporary observers, these materials mostly came from Europe or were reprinted in Lima from European works. They comprised imported books, but also a wide range of copied texts, translations, and compilations, which according to contemporaries, dominated book commerce in the Peruvian capital. The following chapter examines 
elites' commitment to democratic models of reading and popular enlightenment within the walls of the most emblematic symbol of their republican educational agenda. 


\section{CHAPTER II}

For Erudition Only: Lima’s Public Library, 1821-1912

On August 28, 1821, three years before Argentine general José de San Martín (1778-1850) and his allies secured Peru's political independence from Spain, he ordered the establishment of a public library in Lima. ${ }^{179}$ San Martín and some of the men involved in the foundation of the library believed the institution would complement other efforts to educate the masses by providing a place of study for select men of science and letters. The cultured men would then spread their knowledge among other sectors of society. ${ }^{180}$ This vision contrasted with other views and official regulation which characterized the institution as democratic and inclusive, opening the library's doors to "all people." 181 This chapter analyzes the contradictory functions outlined for the library by its founders and administrators, as well as the everyday realities that shaped the experiences of library users. For much of the nineteenth century, elites' own limited visions for the institution, political instability, insufficient funding, and understaffing limited the library's functionality for diverse groups. In spite of its limitations, a growing number of readers visited the library by the end of the century, a process that revealed the tensions between elite and democratic models of reading in republican Peru. ${ }^{182}$

\footnotetext{
179 "Estableciendo una biblioteca pública en Lima," August 28, 1821, Archivo Digital de la Legislación del Perú (ADLP).

180 "Estreno de la Biblioteca Nacional," Gaceta del gobierno de Lima, September 18, 1822, (ADLP).

181 "Estableciendo una biblioteca pública en Lima."

182 Ricardo Palma mentions the growing number of library visitors in several of his administrative reports during his tenure as director of the library between 1883 and 1912. See for example, Ricardo Palma, Memoria que presenta el Director de la Biblioteca Nacional, correspondiente al Bienio de Julio de 1888 a
} 
The relatively small body of historical work on Latin American national or public libraries presents their foundation as a result of an ideological rupture from a colonial view of libraries as centers for the erudition of a select group of male jurists, royal administrators, and clerics. ${ }^{183}$ The shift in these views is validated by the anti-Spanish and nationalist discourse of founders and administrators who used the libraries as physical representations of their commitment to popular enlightenment, and as symbols of intellectual independence and departure from a tyrannical and decadent Spain. ${ }^{184}$ For the Peruvian case, Pedro Guibovich argues San Martín's decree called for a library of public and "national character" different from earlier colonial attempts to establish a

1890 (Lima, 1890), 11 and Memoria del Director de la Biblioteca Nacional 1897 (Lima: Imprenta del Estado, 1897), VI.

183 The rare works on national libraries include some compilations of sources for the history of singular national libraries, but with no sustained historical analysis. See for example María del Carmen Ruiz Castañeda, et. al., La Biblioteca Nacional de México: testimonios y documentos para su historia (México, D.F.: Universidad Nacional Autónoma de México, Instituto de Investigaciones Bibliográficas, Biblioteca Nacional / Hemeroteca Nacional, 2004), an older work by Rafael Carrasco Puente and Erwin K. Mapes, Historia de la Biblioteca Nacional de México (México: Secretaría de Relaciones Exteriores, Dept. de Información para el Extranjero, 1948), and Guillermo Hernández de Alba and Juan Carrasquilla Botero, Historia de la Biblioteca Nacional de Colombia (Bogotá: Instituto Caro y Cuervo, 1977). On the shift toward the model of "national library" see Nelson Schapochnik, "Un palacio de libros en los trópicos: metáforas, proyectos y la fundación de la Biblioteca Nacional en Río de Janeiro," Ayer, No. 58, Historia de la lectura (2005): 113. Using traveler accounts and administrative documents, Schapochnik supports the view of an ideological — and practical, if subtle — shift in the day-to-day services of Brazil's national library. Notwithstanding their limited sources on library users, other works have argued more strongly that citizens easily accessed national library collections. See for example, José Raúl Silva Castro, "Los primeros años de la biblioteca Nacional de Chile (1813-1824)," Revista de Historia de América, No. 42 (Dec., 1956): 385-386; and José Torre Revello "Bibliotecas en el Buenos Aires antiguo desde 1729 hasta la inauguración de la Biblioteca Pública en 1812," Revista de Historia de América, No. 59 (Jan. - Jun. 1965): 91).

${ }^{184}$ See Pedro Guibovich, "La usurpación de la memoria: el patrimonio documental y bibliográfico durante la ocupación chilena de Lima, 1881-1883," Jahrbuch für Geschichte Lateinamerikas 46 (2009), 89-90; and William Acree, Everyday Reading: Print Culture and Collective Identity in the Río de la Plata, 1780-1910 (Nashville: Vanderbilt University, 2011), 27-30. On the broader political use of anti-Spanish rhetoric and its origins in the "Black Legend" see Wim Klooster, Revolutions, in the Atlantic World: A Comparative History (New York: New York University Press, 2009), 147-148. 
public library in Lima destined for an exclusive group of readers. ${ }^{185}$ He notes Lima’s national library remained a center for erudite scholars, but attributes this to the library's colonial collections, which attracted a small group of historians and bibliographers. ${ }^{186}$ The library's collections certainly influenced attendance in the reading hall, particularly during the early nineteenth century; however, this chapter questions the commitment of some library founders and administrators to a democratic model of reading for the institution and exposes their role in curtailing access to reading materials. It concurs with historian Carlos Aguirre's recent observation that Latin American libraries emphasized "preservation over wide use and circulation" and restricted access to their collections to a small group of enlightened elites, belying "their mandate as public libraries."187

Laws and institutional documents help discern the ideological foundations and administrative history of the library, but the same materials pose significant challenges

\footnotetext{
185 Pedro Guibovich, "La fundación de la Biblioteca Nacional del Perú" (presentation, Seminario Internacional "La cultura del libro: aproximaciones desde la historia y el arte," Lima, Peru, August 22-23, 2013).

${ }^{186}$ Pedro Guibovich, "La usurpación de la memoria," 90. A robust body of work has addressed the content of colonial libraries, see the recent historiography by Teodoro Hampe Martínez, "La historiografía del libro en América hispana: un estado de la cuestion" in Leer en Tiempos de la Colonia: Imprenta, Bibliotecas y Lectores en la Nueva España, ed. by Idalia García and Pedro rueda Ramírez (Mexico City: Universidad Autónoma de México, 2010), 55-72. On the colonial origins of Peru's national library, see Pedro Guibovich, El Edificio de las Letras: Jesuitas, educación y sociedad en el Perú colonial (Universidad del Pacífico, 2014), 141-154 and Luis Martín, The Intellectual Conquest of Peru, The Jesuit College of San Pablo, 1568-1767 (New York: Fordham University Press, 1968). Luis Martín described the rich bibliography of the library at the Jesuit Colegio de San Pablo before the expulsion of the Jesuits from Spain and its colonies in 1767. Also see Guillermo Lohmann Villena, "Libros, libreros, y bibliotecas en la época virreinal" in Fénix (Lima), Num. 21 (1971).

${ }^{187}$ Aguirre based his comments on the work of Rosa María Fernández de Zamora. See Carlos Aguirre, "Introduction" in Carlos Aguirre et. al., From the Ashes of History: Loss and Recovery of Archives and Libraries in Modern Latin America (Raleigh, NC: Editorial A Contracorriente, 2015), 18. He also contributed a chapter in the same edited volume on the fire that destroyed large portions of Peru's national library in 1943.
} 
for writing about the experiences of readers. Library users left few traces of their reading activities, which partly explains the absence of works on the history of Latin American national libraries, particularly on the reading practices of library patrons. ${ }^{188}$ In the surviving institutional documents of Peru's national library, administrators rarely mentioned their patrons. ${ }^{189}$ More often, documents reveal administrators' fears of pillage over concerns with serving the public, despite official rhetoric that branded the institution as an instrument for popular enlightenment. Some functionaries certainly saw themselves as architects of a more democratic regime, but they also saw themselves as guardians of the national patrimony. These positions posed conflicting responsibilities and obligations, which often led to more restrictive hours and use of reading materials. ${ }^{190}$ Thus, just as administrators made it difficult for some readers to access reading materials, they complicated access to the historian investigating popular reading practices. My approach therefore asks what institutional sources say and omit about everyday library operations and exposes the implications of such operations for library users. ${ }^{191}$ Restriction of library

\footnotetext{
${ }^{188}$ See note 5.

189 These documents can be found in Legajos 69-71, Biblioteca Nacional 1825-1909, Instrucción, Ministerio de Justicia, Culto, Beneficencia e Instrucción (RJ), Archivo General de la Nación (AGN), Lima, Perú.

${ }^{190}$ Director Juan Coello's responses to public criticisms of the organization and operations of the library reveal the conflicting responsibilities and obligations of directors. In his 1844 rebuttal, he opposed requests to implement lending services, even though they would improve overall library services and the experience of users. Coello argued that such a system would be unfair for users who could not pay borrowing fees. See Juan Coello, "Biblioteca Nacional Al crítico titulado el 'curioso lector' en el 'Comercio' del miércoles 21," El Comercio (Lima) June 26, 1843 and "Biblioteca Nacional," El Comercio (Lima), June 7, 1844. Citing the importance of preserving library materials, Director Ricardo Palma later favored shorter library hours and restrictions on access. See Ricardo Palma, "Memorandum para el Senor Ministro de Justicia Dr. D. Arturo García, Rápidas observaciones al decreto supremo de 1.o de Marzo" Legajo 71, Biblioteca Nacional 1883-1909, Instrucción, Ministerio de Justicia, Culto, Beneficencia e Instrucción (RJ), AGN, Lima, Perú.

${ }^{191}$ Examining quotidian actions and attitudes or the "everyday life" of historical subjects has helped scholars address the ordinary experience of unknown historical actors. These approaches have often produced "history from below" and "popular histories" that reveal the historical agency of unknown actors
} 
hours reveal a tension between democratic and more exclusive visions for the library.

Likewise, the omission of statistics of library users and information about activity in the reading hall within administrative documents from the greater part of the nineteenth century shows an inattention to issues concerning serviceability to the public.

The chapter begins with an analysis of the decrees that demanded the foundation of the library and the regulations that governed the administration of the institution and its reading hall. They reflected the nationalist and educational goals of elites as well as conflicting expectations of the type of visitor the library should welcome. In the section that follows, administrative documents and where possible, newspaper articles help reconstruct the administrative history of the institution. It reveals the effects of conflicting views for the library, political instability, understaffing, and insufficient funding on day-to-day operations. The last section focuses on Ricardo Palma's twentyfive-year directorship after the War of the Pacific (1879-1883), a period of reorganization that saw increased tensions over the mission of the library. Literacy rates from directories and census data as well as the first statistics available for the library's reading hall show the expansion of urban readerships and their diversifying interests. The demands of new readers pressured an institution that had long operated for a reduced number of people.

through their repetitive and collective behaviors. The ideas that daily practices follow logical and rational rules and that social practice creates social structures are central to many studies of everyday life. While this chapter does not attempt to write a "history from below," attention to habitual operations of library administrators sheds light on the library's functionality for ordinary readers. For an overview of the concept of "everyday life" in scholarly work, see Andreas Eckert and Adam Jones, "Historical Writing about Everyday Life" in Journal of African Cultural Studies, Vol. 15, No. 1, Everyday Life in Colonial Africa (Jun., 2002): 5-16. 
Visions for a National Library

The language in decrees that established the national library and regulated its functions sheds light on the democratic principles that guided the educational goals of some of the founders and politicians involved in the organization of the institution. Articles in two of the decrees that addressed the organization of the library clearly authorized "any person" or "all persons" to use its books in the reading hall. ${ }^{192}$ The objective of the library, read the preamble to the library's first rules and regulations, was to "provide from its inception, the acquisition of practical knowledge to all the classes of the State." ${ }^{\prime 193}$ Moreover, article 17 particularly promoted the use of the library by young people (jovenes). It encouraged them to ask for assistance from the director (bibliotecario) when seeking to advance their knowledge in a specific subject. The foundation of the library constituted part of the new regime's broader educational goals of spreading practical knowledge among the masses through the establishment of normal schools and Joseph Lancaster's monitorial method. ${ }^{194}$

Peruvian aristocrat and politician José Bernardo de Torre Tagle (1779-1825) and Argentine reactionary Bernardo Monteagudo (1789-1825) favored a less democratic mission for the library. Monteagudo had joined forces with San Martín and Torre Tagle,

\footnotetext{
${ }^{192}$ See "Organizando la Biblioteca Nacional," August 31, 1822, (ADLP) and "Estableciendo una biblioteca pública en Lima."

${ }^{193}$ Ibid; My translation. In the original text: "facilitar desde sus primeros pasos, la adquisicion de conocimientos útiles á todas las clases del Estado."

194 “Disponiendo que se establezca en Lima una escuela normal central,” July 6, 1822, (ADLP).
} 
taking charge of the organization of the library until July $15,1822 .{ }^{195}$ The preamble to a decree signed by Monteagudo and Torre Tagle outlined a more exclusive use of the library by a handful of learned men and contributors to the establishment of the institution. In the decree, issued on February 8, 1822, the signatories highlighted that the library was one of the most efficient forums for the circulation of knowledge "among men of all ages" and a place where they could exchange "the secrets that they have searched for in the depths of nature."196 With this text, the preamble omitted an invitation to women, ensuring the institution's regulations remained consistent with nineteenth-century gendered practices that physically separated men and women in some public spaces. ${ }^{197}$ The text also encouraged the use of the library by men of letters and science, marking a contrast from the more democratic language in articles that sanctioned the use of the library by all people. Moreover, it singled out the right to use the library of those who "encouraged by a nationalist zeal contribute to the execution" of the decree, which left out popular classes without the resources to contribute books to the institution. ${ }^{198}$

\footnotetext{
${ }^{195}$ B. Monteagudo, Memoria sobre los principios políticos que seguí en la administración del Perú, y acontecimientos posteriores a mi separación (Santiago de Chile: Imprenta Nacional, 1823), 20.

196 "Mandando establecer una biblioteca," February 8, 1822, (ADLP). All translations are my own, unless specifed in footnotes. Original text in Spanish: "los secretos que han escudriñado en el fondo de la naturaleza."

${ }^{197}$ In Mexico for instance, as late as the 1860s writer and finance minister Manuel Payno planned to expand the national library and designate a smaller room as a library for the use of women and young girls. See Phillip Jones, "Indispensable in a Civilized Society': Manuel Payno's 'Las bibliotecas de México,"” Libraries \& the Cultural Record, vol. 42, No. 3 (2007): 285. Café owners also provided segregated spaces for women as advertised in "Ojo al aviso," El Comercio (Lima), December 13, 1844.

198 Ibid. Original text in Spanish: “a ella tendrán derecho todos los que animados de un celo nacional, coadyuven á la ejecución del siguiente decreto.”
} 
Monteagudo designated the building to be used for the new library, appointed the first librarians, established the number of employees for its administration, donated his own personal library, and ordered specific funds to be destined for the benefit of the library, but his monarchical and aristocratic ideas alienated him from liberal political elites. He openly supported a constitutional monarchy and warned of the dangers of democracy in a memoir about his administrative duties in Peru. ${ }^{199}$ Under the direction of San Martín, Monteagudo created the short-lived Order of the Sun, which was charged with recognizing and inducting virtuous citizens involved in the foundation of the new republic. ${ }^{200}$ The hereditary privileges of the Order fueled criticisms from the liberal faction led by José Faustino Sánchez Carrión (1777-1825). ${ }^{201}$ They forced Monteagudo into exile in July of 1822 , but upon his return to Lima in 1825 , he was murdered. Prior to his death, Monteagudo had designated the Ministro de Estado y Relaciones Exteriores as the chief director of the library. Taking over this role, Francisco Valdivieso (1773-1829) continued the organization of the library and the preparations for the inauguration.

It took a year for a coterie of donors and administrators to organize and facilitate the grand opening of the library after San Martín's initial decree. As the opening date approached, the official periodical Gaceta del Gobierno reminded its readers that the establishment would be opening soon in spite of the limited time and resources available to the government at a time of war. The newspaper noted that the library had already

\footnotetext{
${ }^{199}$ B. Monteagudo, Memoria sobre los principios politicos que seguí en la administración del Perú, 11. 200 "Instituyendo la Orden del Sol," August 10, 1821 (ADLP) and "Declarando extinguida la Orden del Sol," September 3, 1825 (ADLP).

${ }^{201}$ Pelliza, Mariano A., Monteagudo, su vida y sus escritos, Tomo Segundo, 1816-1825 (Buenos Aires: Imprenta y Librería de Mayo, 1880), 140.
} 
accumulated a large number of precious collections and unique ouvres, which generous and respectable citizens had donated. It highlighted the donations of San Martín as well as those of Peruvian aristocrat and director of the University of San Marcos Dr. Don José Cavero Salazar and San Lazaro’s parish priest Don Antonio Camilo Vergara, men who had been inducted into the Order of the Sun. The issue extoled the donors as model citizens who acted in the interest of the public good and prompted others to follow suit in order to enrich the library and the national museum. ${ }^{202}$

Like the library, the national museum was part of a broader effort to establish cultural and educational centers to promote a new nationalism based on a common culture and history. The Gaceta del Gobierno asked citizens to donate valuable and rare objects that could help build Peruvian natural and historical collections. It highlighted the urgency of preserving artifacts "passed down from the venerable arts of the Incas" as well as classic paintings, statues, busts, and coin collections. ${ }^{203}$ The newspaper compared the actions of donors with those of revolutionaries and called the former "patriots" for helping the formation of a national library and museum. It highlighted that carrying out these projects would showcase the determination and capabilities of a free people. ${ }^{204}$

San Martín and Valdivieso ordered an inauguration with the outmost decorum and the participation of civil, military and religious authorities. Only a few days before the

\footnotetext{
${ }^{202}$ Gaceta del Gobierno (Lima), March 2, 1822.

${ }^{203}$ Gaceta del Gobierno (Lima), March 16, 1822. Original text in Spanish: "Los venerables restos que nos han quedado de las artes que poseían los súbditos del antiguo imperio de los INCAS, merecen reunirse en aquel establecimiento, antes que acaben de ser exportados fuera de nuestro territorio, como lo han sido hasta aquí, por que era un interés de la España, borrar todos los vestigios de la antigua civilización y grandeza."

${ }^{204}$ Ibid.
} 
event, they had ordered that a master of ceremonies preside over government functions to impose order. They believed order was essential for instilling respectability for the government, and showcasing its greatness, stability, and competence. The master of ceremonies needed to introduce government representatives of other countries, and maintain the decorum and respective order while presenting Peruvian government officials, corporations, and citizens. ${ }^{205}$ The decree for the inauguration ceremony of the library outlined a strict program featuring speeches from prominent public officials in front of the cream of Lima's government, military, ecclesiastical and academic bodies. ${ }^{206}$ Chiefs or directors could invite additional members of their respective corporations, but the decree omitted any invitation to the general public. Valdivieso was to begin the ceremony with an opening speech, followed by one of the bibliotecarios, and the participation and pep talks of the Sociedad Patriótica, University of San Marcos, and the colegios of San Martin, Libertad and Independencia. ${ }^{207}$

The ceremony took place on September 17, 1822, gathering civil, military and religious authorities who conjured the most optimistic spirit of the Enlightenment and portrayed the library as instrumental for spreading education. Valdivieso expressed his belief that the nation finally had a rich source of public instruction, which marked the "triumph of enlightenment and liberty — a result of the sacrifice and perseverance of those

\footnotetext{
${ }^{205}$ See "Estableciendo el rango del maestro de ceremonias y su ubicación en los actos públicos," September 13, 1822, (ADLP). The decree was also published in "El Protector del Perú," Gaceta del Gobierno, September 16, 1822.

206 “Señalando el día, para la aperture de la Biblioteca Nacional de Lima, September 14, 1822 (ADLP).

${ }^{207}$ Ibid.
} 
governments that prioritized the education of the people." ${ }^{208}$ After Valdivieso, the library's first librarian and decorated Independence figure Mariano Arce (1782-1852) also spoke of the institution's educational utility and promoted the habit of reading. Other speakers included the Vice President of the Sociedad Patriótica of Lima and the Ministro de Hacienda Hipólito Unanue, the deans of the Universidad de San Marcos, and several of Lima's educational institutions. ${ }^{209}$ Filled with patriotic speeches and music, the ceremony was a pompous display of how the new republican government wanted to present itself - the paternalistic source of progress and enlightenment for the people. People gathered heard the "Marcha del Perú" in one of the first instrumental performances of the national anthem. The Gaceta del Gobierno proudly described the event highlighting the "magnificence"" of the library's building, the "brilliance" of the ceremony, and the "energy" of the performed speeches. ${ }^{210}$

San Martín delivered the last speech, emphasizing the library's objective was to promote universal enlightenment through the select men of letters who would use the library. To San Martín, a successful general and avid enthusiast of the arts and sciences, a national library represented a tool more powerful than armies for sustaining American independence. He urged enthusiast men of letters and of the nation (amantes de las letras

208 “Estreno de la Biblioteca Nacional," Gaceta del gobierno de Lima, September 18, 1822.

209 The members of the Sociedad Patriótica included several men involved in the Independence movement including José Faustino Sánchez Carrión, Mariano Arce Joaquín Paredes and Bernardo de Monteagudo. Through their activities and newspaper organ, El Sol, they sought to foment the ideals of political emancipation from Spain and facilitate the transition between despotic government and a democratic system. It was established on February 12, 1822. See Estuardo Núñez, "Mariano José de Arce, primer bibliotecario," Fenix, 21: 46.

210 "Estrenando la Biblioteca." On August 7, 1821, San Martín had called for a public contest to select the national anthem. José de la Torre Ugarte won the contest which was announced on September 18, 1821. 
$y$ de su patria), and literary corps to visit the library, and read its books in order to foment knowledge and stimulate the habit of reading among the broader populace. While San Martín encouraged the use of the library by certain types of learned users, he omitted an invitation to Lima's broad population. ${ }^{211}$

The number of attendees to the ceremony is unclear, but orders for the event did not mention any provisions for inviting the general public. According to the Gaceta, the attendees included members of various tribunals and corporations. As the party took their seats, surrounded by a growing number of men of letters and "other people," Valdivieso began his speech. Considering the designation of the sala mayor inside the library as the place of the inauguration, the decree which invited only members of specific corporations, and the close adherence to directions on the same decree, additional attendees probably only included people associated with members of government, military, church, and educational institutions. ${ }^{212}$

Despite the exclusivity of the event, the numerous articles that described the organization, and inauguration of the library as well as word of mouth from the attendees made the opening ceremony a very public event. Indeed the organization and decorum ordered by San Martín and Valdivieso was meant for a public spectacle, whether directly witnessed, read in a newspaper or heard by word of mouth among the populace. The ultimate goal was to inspire respect for the new government through showcasing its capacity to create institutions for the common good. The decrees and laws as well as the

\footnotetext{
211 “Estreno de la Biblioteca Nacional," Gaceta del gobierno de Lima, September 18, 1822.

212 “Señalando día, para la apertura de la Biblioteca Nacional de Lima,” September 14, 1822, ADLP.
} 
inauguration of the library fulfilled the need of the new government to distance itself from the ancien régime and legitimize the new republican state by highlighting its role as benefactor and promoter of education. Ultimately, San Martín, Monteagudo and Valdivieso sent the public mixed messages regarding the mission of the library. The public was not invited and the speeches and decrees, while authorizing all persons to use the library and noting its broad "utility" for the masses, emphasized its functionality for select groups.

Trials of Administering the National Library

Even if the founders and administrators of the library had set out to promote the use of the institution by broad groups, military conflicts and persistent administrative problems prevented the institution from becoming a regular and popular center for learning. The library endured pillaging from Spanish troops in 1823 and 1824, and from the Chilean army in 1881 when it faced its complete destruction during the War of the Pacific. Military conflicts disrupted the daily functions of the library and led to temporary closures of the reading hall to the public. In between military conflicts, library administrators constantly complained about understaffing and insufficient funding. ${ }^{213}$ These problems generated legitimate concerns for several of the directors who repeatedly objected to extending the hours of operation of the reading hall and to changing library policies to better service the public.

\footnotetext{
${ }^{213}$ Several Latin American national libraries and archives have faced similar financial troubles, state neglect, and looting. The recent edited volume by Carlos Aguirre and Javier Villa-Flores discusses some of these cases. See From the Ashes of History: Loss and Recovery of Archives and Libraries in Modern Latin America (Raleigh, NC: Editorial A Contracorriente, 2015).
} 
The first years of the library were turbulent, forcing administrators to spend more time thinking about how to recover books and punish those who pillaged its contents. Lima's national library opened its doors in 1822 amidst the struggle for political Independence in Peru. Between June 13 and July 16, 1823, Spanish troops occupied Lima, pillaging the library in the process. On its first publication after the retreat of the Spanish troops, Lima's Gazeta del Gobierno de Lima Independiente (previously Gaceta del Gobierno) published a call for all citizens to help recover books and other library property lost during the occupation. Tomas Guido (1788-1866), Brigadier General and Acting Governor, threatened people found with national property or people with knowledge of the location of stolen property with swift, if unequal, punishment if they did not report it. Members of the upper classes (de clase) would be expatriated while others would be enlisted in the army. ${ }^{214}$ In February 1824, Spanish troops pillaged the library again. This time Mariano Arce made a call to the public emphasizing that the institution was missing several rare and valuable works. Arce warned of a less discriminatory punishment. Individuals who failed to return the books would incur a fine of five hundred pesos. All individuals with national property were subject to that order, whether the property was sold to them by Spaniards or acquired through any form other than a legal transaction from the government. ${ }^{215}$

Comparing estimates of initial book donations to the first library inventory conducted in 1825 explains some of the concerns over pillaging during the early years. At

\footnotetext{
${ }^{214}$ Gazeta del gobierno de Lima Independiente, July 19, 1823. 215 “Aviso Oficial," Gaceta del Gobierno (Lima) May 8, 1825.
} 
the time of its inauguration in 1822, donations to the library had totaled 11, 256 volumes -600 of them donated by General San Martín and his ministers Monteagudo and García del Rio. Lima's Cabildo, the University of San Marco and religious corporations donated additional books. ${ }^{216}$ The donation of San Marcos may have included tens of thousands of books from the 1767 confiscation of Jesuit libraries. San Marcos had been the recipient of thousands of volumes from the extinct Jesuit library of the Colegio de San Pablo. Using a 1767 inventory of San Pablo, historian Luis Martín argued it contained about 40 thousand volumes. ${ }^{217}$ According to historian Estuardo Nuñez, San Pablo's collection had remained virtually intact after the Jesuits were expelled from Spain and its colonies in 1767 and the ownership of the books was transferred to University of San Marcos. ${ }^{218} \mathrm{He}$ estimated that total donations to Lima's national library reached to about 100 thousand volumes within the first years. Book historian Pedro Guibovich recently questioned Martín's figure of 40 thousand books from San Pablo. Guibovich argued the books only totaled 32,885 and that this number also included numerous books from other Jesuit institutions and private libraries that were confiscated in $1767 .{ }^{219}$ Even if Guibovich is correct, the 1825 inventory only yielded 14,178 volumes or less than half

\footnotetext{
${ }^{216}$ Ricardo Palma, "La antigua biblioteca" in Memoria que presenta el director de la Nueva Biblioteca Nacional en el acto solemne de su inauguración el 28 de Julio de 1884 (Lima: Imprenta del Universo de Carlos Prince, 1884), 4. See also Pedro Carbó, Memoria sobre las bibliotecas públicas, populares, circulantes y escolares, de Europa y America (Guayaquil: Imprenta de "El Telegrafo", 1887), 78.

${ }^{217}$ Luis Martin, The Intellectual Conquest of Peru, The Jesuit Colege of San Pablo, 1568-1767 (New York: Fordham University Press, 1968), 96.

${ }^{218}$ Estuardo Nuñez, "Mariano José de Arce, primer bibliotecario" Fenix, 21, 48.

${ }^{219}$ Pedro Guibovich, El edificio de las letras: Jesuitas, educación y sociedad en el Perú colonial (Lima: Universidad del Pacífico, 2014), 151-152.
} 
of the smaller estimate of books. ${ }^{220}$ In addition, the library received many more collections from Lima notables Hipólito Unanue, Manuel Pérez de Tudela, José Cavero Salazar, Antonio Camilo Vergara, Joaquín Bonet, Martín de Osambela, and the exiled guayaquileño Joaquín Olmedo. The government also sent an envoy to bring additional books from London.

The Gaceta de Gobierno noted the tremendous loss and disruption to the library's activities. On June 12, 1825, it proudly announced the reopening of the library during its usual hours, but it compared the pillaging of the national library to the destruction of the library of Alexandria. It repudiated the behavior of Spanish troops who "destroyed most of it because where Spaniards see light and good they extinguish and destroy it."221 The note highlighted the role of the new government in privileging the reorganization of the library by providing ways to restore it to its previous splendor. It invited men of letters and the studious youth to attend and make use once again of Lima's "abundant medium for the acquisition of knowledge."222

Insufficient staffing, however, limited the utility of the library as a space for erudition during and between military conflicts. At the time of the library's inauguration, San Martín decreed that the institution would be serviced by nine employees including two librarians or library directors (bibliotecarios), two library officials, two conservators,

\footnotetext{
${ }^{220}$ Guía política, eclesiástica y militar del Peru (Lima: 1842), 84.

${ }^{221}$ Gaceta del Gobierno (Lima), June 12, 1825. Original text: “Los Españoles, ya que no llevaron en la mano la tea de los bárbaros, la destruyeron en su mejor parte; por que los Españoles donde quiera que ven la luz y el bien la apagan y destruyen."

${ }^{222}$ Ibid.
} 
and two scribes (amanuenses). ${ }^{223}$ Initially, librarians needed to alternate responsibilities so one was always present, but for most of the nineteenth century, the library only functioned with one librarian. The librarian became more of a director, responsible for all the books and library property, overseeing employees, and keeping order in the institution. ${ }^{224}$ Library officials needed to keep inventory books in order, including an alphabetical index that detailed the number of volumes, quality of bookbinding, and bookshelf location for all the books in the institution. Another book would register the names of the books by subject and bookshelf. In a third book, officials were to list new acquisitions of the library with dates and prices, as well the titles of outgoing books whether for the purpose of sale, trade or as a result of their degraded status. Employees also needed to keep track of correspondence. The responsibilities of conservators included dusting, cleaning and inspecting books and bookshelves in order to prevent mites from destroying them. The job of the scribe required that he record "everything that occurred and was appropriate regarding the service of the library." The rules and regulations decreed on February 8, 1822 added the position of a doorman, which raised the number of employees to nine. Regulations stipulated an annual salary of 800 pesos for each of the librarians, 700 for each of the officials and conservators, 500 for each of the scribes, and 300 for the doorman. ${ }^{225}$

\footnotetext{
223 "Mandando establecer una biblioteca," February 8, 1822 (ADLP).

224 “Organizando la Biblioteca Naciona,” August 31, 1822 (ADLP).

${ }^{225}$ Ibid.
} 
The nine employees were also in charge of servicing the reading hall, which was to remain open all days from 8 am until $1 \mathrm{pm}$ and from 4 to $6 \mathrm{pm}$, except on national holidays. Any person who wanted to read a book needed to request it from one of the library's employees and use the reading hall for study. This requirement alone meant that people who could read, but not write were unlikely to make use of the library's services. The library would provide a seat, a table, a lectern and ink. Library visitors were prohibited from getting their own books and from entering the deposit rooms. They were to remain quiet with the sole purpose of reading. ${ }^{226}$ Books were not to leave the library for any reason. Young people seeking to learn about any given subject could request help from the librarian.

Not long after official regulations for the library set the number of employees and their responsibilities, the institution suffered a major setback. In late 1825, when Mariano Arce quit as first librarian, second librarian Joaquín Paredes took his position, but the government did not replace the latter. ${ }^{227}$ Simon Bolivar, who had taken charge of the central government in 1824 , placed the library under the purview of the newly created Ministerio de Instrucción Pública, Beneficencia, y Negocios Eclesiásticos and reduced the library's employees by two thirds. For the following decades, the institution

\footnotetext{
${ }^{226}$ Although silent reading developed in medieval Europe it took several more centuries, the proliferation of reading materials, and the spread of literacy for it to overtake oral reading to become a preferred practice among readers. Citing the nuisance of reading in public and being interrupted, the editors of El Comercio pressured library administrators to implement lending services in 1844. See editorial in El Comercio, May 31, 1844. On the history of silent reading see Paul Saenger, Space Between Words: The Origins of Silent Reading (Stanford University Press, 1997); Alberto Manguel, A History of Reading (New York: Penguin, 1996).

${ }^{227}$ Juan Coello al Señor Presidente de la Junta Conservadora, July 11, 1842. Ministerio de Justicia, Culto, Beneficencia e Instrucción, RJ Legajo 70. 1838-1882.
} 
functioned with one librarian, one conservator, one scribe and sometimes, with the assistance of temporary employees.

When the staff was reduced, salaries appeared to have increased for some of the employees but only to be cut in half in $1839 .{ }^{228}$ According to an 1842 request for the restitution of salaries from director Juan Coello, his position had earned up to two thousand pesos while the conservator earned one thousand pesos prior to 1839. After that year, the director's salary changed to one thousand pesos and the conservator's salary dropped to five hundred pesos. The salary of the scribe never increased. At the library's foundation, each scribe earned five hundred pesos, but this amount decreased to four hundred in 1825 and to three hundred in 1839 . The doorman had only been assigned 72 pesos, but a decree from May 8, 1840 increased the amount to 144 pesos.

Coello noted that as soon as wages were lowered, the scribe began missing workdays and neglecting his duties (y cometio abusos, que se hizo preciso pedir su reparacion). Similarly, the conservator stopped showing up for work at his assigned hours and allowed some books to go missing, leaving Coello to pay for the books out of his own pocket (y ha dejado perder algunos libros, los que el Bibliotecario va reponiendo de su peculio). ${ }^{229}$ Coello insisted that his request was minimal and only amounted to eight hundred additional pesos per year. This amount, he noted, could be covered with less than half of the wages of the least ranking military chief (menos del

\footnotetext{
2281842 Guía confirms that salaries were cut in half in 1839. Also see Colección de leyes, decretos y ordenes: publicadas en el Peru desde su independencia en el año 1821, hasta 1852, Volumen 6 (Peru: J. Masias, 1842), 303.

${ }^{229}$ Juan Coello to Señor Presidente de la Junta Conservadora, Lima July 11, 1842, Ministerio de Justicia, Culto, Beneficencia e Instrucción, RJ Legajo 70. 1838-1882, AGN.
} 
medio haber del ultimo Jefe del Ejercito). Coello believed many of them should retire from their military careers since their services were not nearly as useful or a matter of public interest as was the work of library employees.

The downsizing of the library's staff and their wages reflected an inattention to the more democratic visions for the library which emphasized its utility for promoting reading habits and educating Lima's residents in general. Bleak state finances in the decades following independence explain part of the problem. Peru had inherited substantial debt from the colonial regime, but it also incurred heavy debt from military expenditures during the struggle for independence. The government contracted loans from British bondholders totaling 1,816,000 pounds sterling, but it had defaulted quickly. As historian Peter Klarén noted, "by the late 1820s, the country's foreign debt was five times the government's annual revenues, and by 1848 , it had grown to an estimated $4,380,530$ pounds sterling. The internal debt likewise grew to an estimated 6,646, 344 pesos by $1845 .{ }^{, 230}$ Much of the government's budget during those years-as much as 70 percent - continued to cover military expenditures used to combat caudillos or regional strongmen who threatened the central government. ${ }^{231}$ Political instability resulted in constant fluctuations in leadership, with no less than twenty-four changes of regimes and a total of six constitutions between 1821 and 1845 .

Likewise, the library underwent constant reorganization, particularly during the 1830s and early 1840s when Peru entered a period of intense internal conflict and

\footnotetext{
${ }^{230}$ Peter Klarén, Peru: Society and Nationhood in the Andes (New York: Oxford University Press, 2000), 144.

${ }^{231}$ Ibid, 144.
} 
international entailments. When liberal Bolivian president Andrés de Santa Cruz orchestrated the Peru-Bolivia Confederation (1836-37), Chile and Argentina declared war. Aided by Peruvian conservatives, Chile invaded in 1837 and in 1838 . The confederation quickly collapsed and conservative caudillo, Agustin Gamarra managed to regain power in 1839. Gamarra invaded Bolivia but died in battle, which engulfed Peru in another civil war that lasted through 1845. During this period, the library had five different librarians, including renowned scholar Dr. Francisco de Paula González Vigil, Bartolomé Herrera, Felipe Ríos, Juan Coello, and Matias Pastor Solis-Vango. ${ }^{232}$ The "revolving door" of directors reflected the contentious and partisan environment that engulfed politics during those years. Coello, for instance, had been under the wing of the Gamarrista faction and his criticism of President Luis José de Orbegoso nearly led to his execution. Once Gamarra came to power again in 1839, he appointed Coello as director.

Although the first directors left no statistics that might provide more information on the experiences of users during the first decades of the institution, newspaper articles provide some clues. In one article, Coello mentioned that the library had no less than 20 visitors per day in addition to travelers and occasional meddlers (curiosos). ${ }^{233} \mathrm{An}$ anonymous article, however, described the deplorable state of the library collections, blaming it on the excessive trust of employees who allowed books to be extracted from the library, the lack of auxiliary hands, and most of all, on the political convulsions of the

\footnotetext{
${ }^{232}$ Paul Gootenberg, Between Silver and Guano: Commercial Policy and the State in, 12.

${ }^{233}$ Juan Coello, "Biblioteca Nacional," El Comercio (Lima), May 31, 1844.
} 
time. ${ }^{234}$ Based on this account, some users enjoyed a degree of privilege, which allowed them to take books home in spite of strict regulations forbidding the practice. However, the article suggested that by 1840 , the library no longer functioned even for its most privileged users, noting that its very "existence was of the most urgent need" ( $l a$ existencia de una Biblioteca entre nosotros es de mas urjente necesidad).

The library remained closed to users for reorganization and repair work between 1839 and 1842, or most of Coello's short directorship. According to Coello, the library was in complete disarray in 1839 . Recently enriched with the donation of 7,772 volumes from former inspector (visitador) Miguel Fuente y Pacheco, the library had no place to store or staff to catalogue the collection. The books covered the reading hall, leaving no space for library users. The reading hall itself was in a deteriorating state with broken beams and partial exposures of the roof. Making matters worse, the library had recently ceded two of its rooms to the national museum, which deprived the library from additional deposit rooms. Coello claimed that the library had not received funds he had been requesting for two years. Instead, the government ordered that he close the reading hall while it was emptied and repaired. ${ }^{235}$

Shortly after the library reopened its doors to the public and in spite of improvements made to the reading hall and library collections, some library users voiced their dissatisfaction. Consider a complaint made by "the inquisitive reader" (el curioso

\footnotetext{
234 “Instrucción pública. Biblioteca Nacional,” El Peruano (Lima), April 4, 1840.

${ }^{235}$ Coello, "biblioteca Nacional Al crítico titulado el 'curioso lector' en el 'Comercio' del Miercoles 21, El Comercio (Lima) June 26, 1843.
} 
lector) on a paid insert (remitido) of El Comercio in June of $1843 .{ }^{236}$ The letter writer described how on a Tuesday morning, he went to Lima's national library in search of a single book. At 10 a.m., two hours after its opening time, the library was still closed. When he heard the librarian was sick and would not be opening for the day, he left. The following Friday morning, the letter writer returned and walked the corridors of the library while he once again waited for the amanuense to open. When other men arrived to use the library, the man struck a conversation with one of the new arrivals. One of them had gone to the library on a daily basis for the previous two months and noted that during that time, he had never met the conservator in charge of the job of the director in his absence. In the course of their conversation, the amanuense finally appeared and opened the door. Some of the visitors took books that they had previously put aside for their own reading while others asked for a variety of new ones. According to the letter writer, the amanuense appeared not to know what he was doing. He asked for the book he needed, but after checking the catalogue, the amanuense told him that he could not find it. As the visitor was getting ready to leave, he noted that the "sick man"-referring to Coello, the current director-entered the room complaining. He delivered the book he was looking for, but before the library user could finish his reading, it was already 1 p.m., the midday closing time for the library. Annoyed, the reader left, but when he returned at 4 p.m. for afternoon hours, the library was closed. It is unclear whether he eventually entered, but

\footnotetext{
236 “Al nacionalismo de S. E. el Supremo Director," El Comercio (Lima), June 21, 1843. Remitidos were paid opinion inserts outside the editorial section. They addressed a variety of subjects, often filling 40 percent of newspaper space or even full issues. By the late 1820s they had become essential for financing Lima's newspapers because paid advertisements and subscriptions were limited. Limeños used remitidos to air their personal grievances and often tried to pressure judges in their legal disputes by swaying public opinion. See Pablo Whipple, La gente decente de Lima y su resistencia al orden republicano (Lima: IEP, 2013), 80-130.
} 
he noted that he left at 5 p.m. since staying later was pointless in the absence of natural light for reading. He completed his public admonition noting:

Here, instead of gaining [knowledge] by having a library, I have lost time in coming and going for two hours of reading that I could not complete. There is no doubt that the masses of a people can become enlightened with a library, if it is well serviced: but not being [well serviced], its conservation is a misunderstood luxury that manifests the misery of the nation that foments it. $^{237}$

Some library users demanded new measures to facilitate the lending of books at a cost, favoring a system that would exclude a large portion of Lima's population who could not afford to pay. In an anonymous remitido of El Comercio "an interested party" (un interesado) complained that the library was only open during working hours when few people could attend. ${ }^{238}$ He urged administrators to allow library users to check out books in exchange for a deposit that totaled the value of the book in addition to one or two reales - depending on the size of the volume - to pay for the reading of the book itself. For the letter writer, this secured payment for the deterioration of the books. ${ }^{239} \mathrm{El}$ Comercio supported this recommendation adding that such a system had been put in practice two years earlier in Lima through a lending library established by young English

\footnotetext{
${ }^{237}$ Ibid. Original text: He aquí, que en vez de adelantar con haber una Biblioteca, he perdido el tiempo en ir y venir para dos horas de lectura, que no pude concluir. No hay duda que las masas del pueblo se ilustran con una biblioteca, estando bien servida: pero no estándolo, su conservación es un lujo mal entendido que manifiesta la miseria de la Nacion que la fomenta.

238 "Biblioteca Nacional," El Comercio (Lima), May 31, 1844. Remitidos were paid opinion inserts outside the editorial section. They addressed a variety of subjects, often filling 40 percent of newspaper space or even full issues. By the late 1820s they had become essential for financing Lima's newspapers because paid advertisements and subscriptions were limited. Limeños used remitidos to air their personal grievances and often tried to sway public opinion with regards to legal disputes in order to pressure judges. See Pablo Whipple, La gente decente de Lima y su resistencia al orden republicano (Lima: IEP, 2013), 80-130.

239 “Biblioteca Nacional," El Comercio (Lima), May 31, 1844.
} 
men. The editors appeared to respond to a growing desire of reading in private for it noted that it was not very pleasant to read "in public exposed to constant interruptions" (en exhibicion, espuestos á ser interrumpidos á cada momento). For the editors, the lack of a lending system made the library's services highly impractical. They complained that the library, like other institutions, appeared to seek the approval of travelers before producing effective results for Peruvians. ${ }^{240}$

Echoing the idealistic and democratic view of the mission of the library, Coello issued a quick response that was also published by El Comercio a week later. He defended the standing regulations arguing that they gave all people equal access to books:

The philosophical and most praiseworthy objective for establishing the national library as one of the first actions after political emancipation, was to educate the masses of a people that had been repressed for three centuries under the enormous weight of peninsular colonialism so that by knowing all of their imprescriptible rights, they would learn to appreciate and sustain their independence and liberty, providing for free the reading of their precious ouvres to the most wretched who wished to be educated and useful to his fatherland. ${ }^{241}$

Coello argued that the proposal for checking out books would unfairly deprive people of lesser means from reading books. Books would remain unused in the houses of the wellto-do, preventing young people who attend the library on a daily basis from reading or

\footnotetext{
240 "Lima," El Comercio, May 31, 1844. Original text: "Nuestras bibliotecas, como muchas de nuestras cosas por desgracia, parece que no tienen por primer fin la utilidad: se forman costosos establecimientos que parece tienden antes á merecer la aprobacion de un viajero que á producir bienes efectivos á la jeneralidad del país."

${ }^{241}$ Juan Coello, "Biblioteca Nacional," El Comercio (Lima), June 7, 1844. Original text: "El objeto filosofico y el mas laudable que se tuvo para establecerse la Biblioteca nacional desde los primeros pasos de nuestra emancipación política, fue el de ilustrar a las masas de un pueblo encorvado por tres centurias bajo el enorme peso del coloniaje peninsular, para que conociendo todos sus imprescriptibles derechos supiesen apreciar y sostener su independencia y libertad, proporcionadose gratuitamente la lectura de sus preciosa obras aun al mas infeliz, que deseára [SIC] instruirse y ser útil a su patria."
} 
consulting them. In addition, it would be difficult to estimate the value of many of the rare books in the library, changes would increment the work of employees, and the library would need several copies of each book. Based on official regulations, propositions for checking out books were never considered by policymakers or library administrators.

Coello only served as director for about three years. Dr. Don Felipe Ríos replaced him briefly in 1843, but the record is unclear regarding Coello's departure. Dr. Matías Pastor Solís-Vango replaced Ríos in 1844, and celebrated liberal priest and scholar Francisco de Paula González Vigil (1792-1875) took the position in 1845, serving until 1875 in the lengthiest directorial period since the library's inauguration. González Vigil made some modest acquisitions of books during his tenure, but funding for the library remained limited even as the government received unprecedented revenue from the guano boom. ${ }^{242}$ El Peruano noted that the one hundred thousand pesos that the library received for the acquisition of new books and other expenses were insufficient to purchase the new and classical works that were published in Europe and could not be found in Peru unless expressly ordered. Moreover, the building still had many inadequacies and needed new furnishings to accommodate its national and foreign visitors.

In 1852, reading hall hours were reduced from 7 to 5 hours, making the use of the library even more impractical. ${ }^{243}$ The irregularity and short reading hall hours led men

\footnotetext{
242 “Instrucción,” El Peruano (Lima), November 6, 1858.

${ }^{243}$ Eduardo Carrasco, Calendario y Guía de Forasteros de la Republica Peruana para el año 1852 (Lima: Imprenta de Felix Moreno, 1852), 74.
} 
like Cavalry Colonel Manuel de Odriozola (1804-1889) to request special favors from the Ministro de Estado. On January 14, 1864, Odriozola — who later worked as library director between 1875 and 1883 - explained that he was in the process of publishing "Documentos Históricos y Literarios del Perú." ${ }^{244}$ He needed to use several handwritten works from the library but argued that he worked during the hours that the library remained open. Thus, he requested a special permission to extract the books while leaving a receipt as a guarantee that he would return them. He stated he would return them exactly as they were delivered and reminded the minister that it was well known he treated his own books with great care. Since the books from the library belonged to the nation, he expressed it gave him an even stronger reason to take painstaking care of them.

The minister forwarded the letter to González Vigil. He agreed to allow Odriozola to have special access to the books. The 1822 rules and regulations strictly forbid library users from extracting any books from the establishment, but Vigil noted that the Supremo Gobierno had allowed individuals to extract books in the past, particularly when doing so was in the "public interest, like in the present case." ${ }^{245}$ Vigil alluded to Odriozola's honor and zeal, finding no reason to deny his request if he left a receipt for the books. González Vigil probably empathized with Odriozola because after all, he too was a man of letters and likely used his access to books and documents in the library to complete some of his

\footnotetext{
244“Señor Ministro de Estado en el Departamento de Justicia,” January 4, 1864, 71 Ministerio de Justicia, Culto Beneficencia e Instrucción Fondo RJ Legajo No 70 Instrucción Biblioteca Nacional 1838- 1882. Odriozola later published this compilation of documents between 1863 and 1877 in 10 volumes under the title Documentos históricos del Perú en las épocas del coloniaje después de la conquista y la independencia hasta la presente. (Lima: Tip. de A. Alfaro, 1863-1877).

${ }^{245}$ Ibid.
} 
works. ${ }^{246}$ The practice of allowing some men to use books outside of the library continued throughout the century and was finally sanctioned by the Reglamento of 1884 , which allowed the director to grant a special license for those library users who wished to take out an integral copy of a manuscript or book. ${ }^{247}$

Manuel de Odriozola succeeded González Vigil as director of the library in 1875 and actively sought to improve the reading experience of library users and the terms for employees. ${ }^{248}$ In 1878 , while the library remained closed, he requested higher salaries for employees. He commented that the library had functioned with nine employees when books did not constitute even half of the collection that it had at the time of his writing. In spite of an increase in library holdings and number of users over the years, the institution had been servicing the public with only three employees and one additional scribe from the national archive. Furthermore, the library used to function with only two rooms, a deposit room, and a reading hall. It had no more than 61 bookshelves with no more than 14 thousand volumes. This, he reminded, was the set up in 1822 when Peru was engulfed in the struggle for independence, Lima had half of its population, and visitors to the library were few. In 1878, the director stated, the library was three times its original size, had approximately 60 visitors per day, and a collection of 50 thousand books.

Odriozola insisted four employees could not adequately fulfill library duties and warned that if his demands were not met, the result would be more pillaging of national

\footnotetext{
${ }^{246}$ Jorge Basadre, "La nueva actualidad de Vigil," 58.

247 “Disposición Urgente," Memoria que el Director de la Biblioteca Nacional presenta al Ministro de Justicia, (Lima: Imp. De "El Pais", 1898), 9.

${ }^{248}$ Manuel de Odriozola to Señor Director general de Instrucción Pública” Lima, June 25, 1878, AGN.
} 
property. Employees, he stated, could not satisfy all of the requirements of the library users while also watching them. The number of readers would decrease and they would do what they have done in the past: rip books apart, write on them, dirty or steal them. The conservator could not always properly help the library users since sometimes he had to cross five different external rooms in order to get the requested books and go up and down stairs to the upper rooms or galleries. Odriozola wanted two conservators strictly dedicated to the retrieval of books and an additional four amanuenses to fulfill their duties appropriately and keep careful watch of readers. He requested new salaries parallel to those of other public servants in less demanding positions. Library employees, he noted, needed knowledge in theory and practice of bibliography in order to maintain library catalogues updated by subject. He proposed a salary of 3,200 soles for the director; 2,400 for an assistant director; 1,800 and 1,200 for a first and second official, respectively; 1,000 for each of two conservators; 600 for each of four scribes; 300 for each of three peons; 360 for the doorman; and an additional 240 for office supplies. The budget totaled 14,500 soles. ${ }^{249}$ The new regulations of 1879 stipulated that only ten employees would service the library, including one director, one assistant director, two watchmen, four conservators, one scribe, and one doorman. While Odriozola's full proposal was not accepted, ten employees was a significant improvement over the previous number. ${ }^{250}$

\footnotetext{
${ }^{249}$ Manuel de Odriozola, "Proyecto de reforma de la Biblioteca Nacional en el número y dotacion de sus empleados," Lima, June 25, 1878, Ministerio de Justicia, Culto, Beneficencia e Instrucción, RJ Legajo 70, 1838-1882, AGN.

250 "Reglamento para la Biblioteca Nacional de Lima", May 12, 1879, ADLP.
} 
The War of the Pacific, a military conflict over access to nitrates, which involved Peru and Bolivia against Chile, interrupted improvements from the new regulations. On January 17, 1881, Chileans captured and occupied Lima. Shortly after, on February 6, Odriozola was asked for the keys to the library, which initiated "the most scandalous and arbitrary pillage" (dándose principio al más escandaloso y arbitrario despojo). ${ }^{251}$ The Chilean army destroyed and stole most of the library's volumes. The invaders used the library as barracks and one of its rooms as a stable for horses. In a protest letter written on March 10, 1881 to U.S minister Isaac Christiancy, Odriozola described the dire situation as books were taken away, he believed, to Santiago. Those volumes that were not sent to Chile were sold at cheap prices in Lima's bodegas. The director condemned the Chilean appropriation of libraries, archives, scientific instruments, art pieces, and all which he believed was necessary for intellectual progress. ${ }^{252}$ The theft of books must have been particularly devastating to the independence war hero and bibliographer who, prior to becoming director, had tirelessly worked toward compiling historical documents and creating a national literature. A copy of his protest was remitted to the government in Ayacucho, which later published it in the official newspaper. General Patricio Lynch, Chilean chargé of government affairs in Lima, ordered the capture of Odriozola, but he managed to seek asylum with the American delegation. The military conflict ended in 1883 , and the long process to rebuild the library began with a change of directors. Considering Odriozola's age and his physical ailments, President Miguel Iglesias

\footnotetext{
${ }^{251}$ Manuel de Odriozola, "Protesta del bibliotecario de Lima", Lima, March 10, 1881. ${ }^{252}$ Ibid.
} 
determined that he was unable to execute the arduous reorganization process of the library. ${ }^{253}$ Iglesias appointed writer Ricardo Palma as a new director. ${ }^{254}$

For decades, directors had expressed concerns with guarding library property, declining to implement lending services or extend library hours in order to maintain order and vigilance of library contents and patrons. Their custodianship of library property helped amass 50 thousand printed volumes and more than 800 manuscripts by 1880 . Palma's assessment of the damages revealed that war posed a much greater threat to the national patrimony than did the everyday use of library property by patrons. Only 738 books and "a memory" of the rich manuscript collection survived the Chilean occupation. Moreover, Palma described cedar bookshelves that were destroyed and left without shelves and glass panes and lanterns completely broken. The building needed urgent repair since all the pipework was destroyed and there were roofs and walls in danger of collapse. The rooms for the directors of the library and national archive were in similar shape. Palma called on the government to give preference to the repairs of the building and the shelving units, while he made sure that books were replaced without additional costs to the treasury. ${ }^{255} \mathrm{He}$ became very successful in acquiring books with little or no cost to the treasury, proclaiming himself the "mendicant librarian" (el bibliotecario

\footnotetext{
${ }^{253}$ Miguel Iglesias, November 2, 1883.

${ }^{254}$ Ricardo Palma Al Senor Oficial Mayor del Ministerio de Justicia, Culto, Instrucción y Beneficencia, Lima, November 5, 1883.

255 Ricardo Palma al Senor Ministro de Estado en los Ramos de Justicia e Instruccion, Lima Noviembre 14, 1883, AGN.
} 
mendigo $).{ }^{256}$ Less than a year after his appointment, Ricardo Palma was planning the inauguration of the new library.

Lima's New Library and its "literatos de cajetilla de cigarros"

The second inauguration of the library, with its use of national insignia, became a public spectacle that once more presented the national library as a symbol of the dawn of a new era. Palma scheduled the ceremony for the 1884 commemoration of Peruvian Independence. ${ }^{257}$ Some of the expenses for the event included the purchase of a flag and 240 chairs by library employee and future director and historian Carlos A. Romero. ${ }^{258}$ The epitaph on the new library seal printed on the 500 invitations to the event read "After the clouds, the sun" (Post Nubila Phoebus) in Latin, alluding to the tempestuous recent events and to the library's revival. ${ }^{259}$ The second page had a second seal with a wreath enclosing the names of President Miguel Iglesias, Ministro de Instrucción Mariano Castro Zaldívar, Ministro de Hacienda Manuel Galup, and Bibliotecario Ricardo Palma. A special publication, Memoria de la Nueva Biblioteca Nacional, with a print run of 500 bounded copies, described the collective and painstaking work of rebuilding the

\footnotetext{
${ }^{256}$ Ricardo Palma al Senor Ministro de Justicia e Instrucción, Abril 28, 1884, AGN.

${ }^{257}$ The invitation was physically attached to Palma's op. cited. 1884 Memoria.

${ }^{258}$ Ricardo Palma, Cuenta documentada que presenta el Director de la Biblioteca Nacional de la inversión dada a los 1,500 soles que recibió para gastos de inauguración del establecimiento. Lima, August, 18, 1884. AGN.

${ }^{259}$ See receipt number 16 in Palma's Cuenta documentada que presenta el Direcotr de la Biblioteca Nacional de la inversion dada a los 1,500 soles que recibió para gastos de inauguracion del establecimineto.
} 
library. ${ }^{260}$ Library conservator Enrique Torres Saldamando compiled a list of names of 78 benefactors who donated books. Juan José Moreira gave the largest collection at 2,000 volumes and all other named donors gifted between 225 and 10 volumes. ${ }^{261}$ An additional 1,160 volumes came from unnamed donors who gave between 1 and 9 books.

Administrative documents show that the optimism of the inauguration gave way to familiar concerns over understaffing and guarding library property, but Palma commented more extensively than his predecessors on the reading hall and its visitors. In his first report for the years between 1884 and 1888, Palma complained that even after the 1879 Reglamento had assigned ten employees to the institution, the library only operated with eight employees, including four conservators, one scribe, two peons, and one doorman. Moreover, after the merging of the library and the National Archive began in 1883, employee duties were divided between the two entities. ${ }^{262}$ Complaints of understaffing echoed those of other directors, but Palma described a dire situation with destructive and disorderly behavior in the reading hall. "Out of laziness," he noted, readers did not copy verses onto separate paper but pulled out the illustrations and text pages, particularly in newspapers and poetry books. ${ }^{263}$ It had already happened to some rare volumes such as the first issue of El Comercio. He blamed bad habits or deficient

\footnotetext{
260 "Anexos" in Ricardo Palma, Memoria de la Nueva Biblioteca Nacional (Lima: Imprenta del Universo de Carlos Prince, 1884), 22-23, Fondo Antiguo, Biblioteca Nacional, Lima, Peru.

${ }^{261}$ See "Anexos" in Ricardo Palma, Memoria de la Nueva Biblioteca Nacional (Lima: Imprenta del Universo de Carlos Prince, 1884), 22-23, Fondo Antiguo, Biblioteca Nacional, Lima, Peru.

${ }^{262}$ Ricardo Palma, Memoria que presenta el Director de la Biblioteca Nacional correspondiente al Cuatrenio del 28 de Julio de 1884 al 28 de Julio de 1888 (Lima: Imp. Masias, Ca., 1888), 11-12.

${ }^{263}$ Ricardo Palma, Memoria que presenta el Director de la Biblioteca Nacional, correspondiente al bienio de Julio de 18888 a 1890 (Lima, 1890), 11.
} 
education for "the spirit of destruction" which overtook library users and hoped to see more restrictions in order to limit "access only to those who request works for consultation in the different branches of human knowledge."264

Library users left few traces of their actual activities, so it is difficult to assess the validity of Palma's claims regarding their destructiveness and disorderliness in the reading hall. At least some of Palma's own observations call into question the severity of the issue. Between 1884 and 1888, he could only cite two cases of theft, and between 1884 and 1890, Palma had only denied entrance to four library users over the suspicion that they damaged books. ${ }^{265}$ In 1897 , he did the same for only two library users. ${ }^{266}$ Certainly, understaffing posed a problem for the effective surveillance of readers in the reading hall, but with the average number of users at 40 or 60 per day, these cases seem to be exceptions rather than the rule. ${ }^{267}$

Palma's uneasiness reflected mounting pressure from Lima's expanding readerships, a result of a growing population and improved literacy rates in the second half of the nineteenth century. Between the inauguration of the library in 1822 and the

\footnotetext{
${ }^{264}$ Ibid, 11. Original text: "Casi puede afirmarse que, entra por mucho el espíritu de destrucción, como resultado de malos hábitos ó de educación descuidada. No somos afanosos para conservar; pero sómoslo para destruír...Mucho me holgaría de ver restringido el derecho de concurrir al salon de lectura, limitándo sólo á los que solicitan obras de consulta en los diversos ramos del saber humano. Sólo así tendremos Biblioteca Nacional digna de este nombre."

${ }^{265}$ Ricardo Palma, Memoria que presenta el Director de la Biblioteca Nacional, correspondiente al bienio de Julio de 1888 a 1890, 11 and Ricardo Palma, Memoria que presenta el Director de la Biblioteca Nacional correspondiente al Cuatrenio del 28 de Julio de 1884 al 28 de Julio de 1888 (Lima: Imp. Masias, Ca., 1888), 11-12.

${ }^{266}$ Ricardo Palma, Memoria 1897, VII.

${ }^{267}$ Ibid.
} 
reopening of 1884 , Lima's population nearly doubled. ${ }^{268}$ Literacy rates are more difficult to determine, but some evidence suggests they remained stable during the first half of the nineteenth century. According to historian Pablo Macera, during the last decades of the colonial period, only about 20 percent or about 1,000 school-age Limeños could read. Another study showed that about 12 percent of Limeños between 8 and 21 years of age attended some other educational institution. ${ }^{269}$ While these figures do not provide exact literacy rates for the overall population, they show the percentages of the population exposed to at least one year of formal education. These figures are also consistent with estimates of other historians for the same period. ${ }^{270}$ An 1845 register suggests literacy rates in Lima remained stable through 1845 with only 20 percent of the male and female population "trained in reading but not in writing." 271 By 1860, however, 55 percent of Lima's population could read and write. Census data show that the number increased to 61 percent in 1891, and to 80 percent in $1908 .{ }^{272}$

\footnotetext{
${ }^{268}$ According to one source, Lima had a population of 64,000 in 1820 and it gradually increased to 100,341 in 1860. See Almanaque del Comercio de Lima 1876 (Lima: Imprenta del Estado, 1876), 72. Paul Gootenberg estimates the population was actually 58,326 in 1827 , see his work on Lima's demography, Población y etnicidad en el Perú republicano (siglo XIX), Algunas revisiones (Lima, IEP, 1995), 21. An 1891 census had Lima's population at 103,956, see Almanaque de "El Comercio" para 1892 (Lima: Imprenta de "El Comercio", 1892), 165. The official 1908 census had the population at 120,254. 102.

${ }^{269}$ See Pablo Macera, "Noticias sobre la enseñanza elemental en el Perú durante el coloniaje," in Trabajos de historia, vol. II (Lima: Instituto Nacional de Cultura, 1977), 258 and Cristóbal Aljovín de Losada, Caudillos y constituciones (Perú, 1821-1845 (Lima: Instituto Riva-Agüero, Fondo de Cultura Económica, 2000). Both works and figures are discussed in Jose Ragas, "Leer, escribir, votar. Literacidad y cultura política en el Perú (1810-1900),” 115.

${ }^{270}$ See Carlos Newland, "La educación elemental en Hispanoamerica: Desde la independencia hasta la centralizacion de los sistemas educativos nacionales," The Hispanic American Historical Review, Vol. 71, No. 2 (May, 1991), 357.

${ }^{271}$ Jose Ragas, "Leer, escribir, votar. Literacidad y cultura política en el Perú (1810-1900),” 115.

272 The literacy rates for 1876 and 1891 are listed in Almanaque de "El Comercio" para 1892, 167; Census $1908,102$.
} 
Even as Lima's readers multiplied and more people sought to use the library, reading hall hours decreased. Administrative documents from the first directors omitted official statistics of library users; however, in the early 1840s, Juan Coello noted that at least 20 patrons used the reading hall each day. ${ }^{273}$ Based on the statistics of Manuel Atanasio Fuentes this figure did not change much by 1858 when 20 to 25 users visited the library every day. ${ }^{274}$ In 1878 , Odriozola commented on the increasing number of users, stating the average reached 60. Palma later claimed that the reading hall had never had a larger number of visitors than during his tenure. ${ }^{275}$ Based on this information, it is possible to conjecture that library users increased, and likely tripled between the 1840 s and 1870s, but during those years, hours were reduced twice. Upon foundation of the institution, regulations stipulated that the library would remain open for seven hours, between 8 a.m. and 1 p.m., and between 4 and 6 p.m. ${ }^{276}$ In 1852, library hours were reduced to 5, opening from 10 a.m. to 3 p.m. only. ${ }^{277}$ In 1879 , the new regulations reduced service hours again to a mere four hours or from 12 to 4 p.m. ${ }^{278}$ Despite these

\footnotetext{
${ }^{273}$ Juan Coello, “Biblioteca Nacional,” El Comercio (Lima), May 31, 1844.

${ }^{274}$ Manuel Atanasio Fuentes, Estadística General de Lima (Lima: Tipografía Nacional de M. N. Corpancho, 1858), 246.

${ }^{275}$ Ricardo Palma, Memoria que presenta el Director de la Biblioteca Nacional correspondiente al Cuatrenio del 28 de Julio de 1884 al 28 de Julio de 1888, 11-12.

276 The hours listed in the Calendario y Guía de Forasteros de Lima published before the 1852 issue matched those listed in the first rules and regulations of the library, see the op. cited "Organizando la Biblioteca Nacional" and Calendario y Guía de Forasteros de Lima for the years 1823-1850, Sala de Libros Raros y Manuscritos, Biblioteca Nacional.

277 Calendario y Guía de Forasteros de la Republica Peruana para el año bisiesto de 1852 (Lima: Imprenta de Felix Moreno, 1851), 74.

278 “Reglamento para la Biblioteca Nacional de Lima," May 12, 1879 (ADLP).
} 
changes, the average number of users leveled at 40 to 60 per day during the early reorganizational phase of Palma's tenure (see Table 3).

Table 3. Library Users at the National Library and Books Borrowed from 1884 to 1911

\begin{tabular}{|c|c|c|c|}
\hline Year (s) & $\begin{array}{l}\text { Library users per } \\
\text { year }\end{array}$ & $\begin{array}{l}\text { Library users } \\
\text { per day }\end{array}$ & Number of volumes \\
\hline 1884-1888 & N/A & $40-60$ & N/A \\
\hline $1888-1890$ & N/A & 40 & N/A \\
\hline $1890-1892$ & N/A & $30-42$ & 23,617 \\
\hline 1892-1893 & N/A & 40 & 11,049 \\
\hline 1893-1894 & 1,233 & 40 & 12,215 \\
\hline 1894-1896 & 2,628 & N/A & 22,318 \\
\hline 1897 & 2,978 & N/A & 12,482 \\
\hline 1898 & 2,813 & N/A & 11,219 \\
\hline 1899- 1900 & 2,873 & N/A & 11,831 \\
\hline 1901 & N/A & N/A & N/A \\
\hline $1902-1903$ & N/A & 60 & 11,954 \\
\hline $\begin{array}{l}1905 \text { (data } \\
\text { for } 10 \\
\text { months only) }\end{array}$ & 6,319 & N/A & 7,144 \\
\hline $\begin{array}{l}1906 \\
\text { (opened for } \\
\text { night hours) }\end{array}$ & $\begin{array}{l}7,334 \text { by day } \\
5,328 \text { by night }\end{array}$ & $\begin{array}{l}24-75 \text { per day } \\
9-47 \text { per night }\end{array}$ & $\begin{array}{l}8,979 \\
5,760 \text { night }\end{array}$ \\
\hline 1907 & $\begin{array}{l}7,461 \text { by day } \\
4,159 \text { by night }- \\
10 \text { months }\end{array}$ & $\begin{array}{l}27-71 \text { per day } \\
11-33 \text { per night }\end{array}$ & $\begin{array}{l}9,172 \text { by day } \\
5,318 \text { by night }\end{array}$ \\
\hline 1908 & N/A & $\begin{array}{l}14-57 \text { per day } \\
12-37 \text { per night }\end{array}$ & N/A \\
\hline 1909 & $\begin{array}{l}10,283 \text { by day } \\
4,136 \text { by night }\end{array}$ & N/A & $\begin{array}{l}12,127 \text { by day } \\
4,214 \text { by night }\end{array}$ \\
\hline $\begin{array}{l}1910 \\
\text { (irregular } \\
\text { night hours) }\end{array}$ & 7,000 by day & N/A & 8,170 by day \\
\hline $\begin{array}{l}1911 \text { (night } \\
\text { hours closed) }\end{array}$ & 10,423 by day & N/A & 11,714 \\
\hline
\end{tabular}

Source: These figures correspond to Ricardo Palma's annual reports published between 1884 and 1912. See Ricardo Palma, Memoria que presenta el Director de la Biblioteca Nacional (Lima: Imp. Masias, Ca., 1884-1912). 
Palma opposed most efforts to extend library hours. When the library reopened in 1884, regulations stipulated that the reading hall service users from 12 to 5 p.m. ${ }^{279}$ In 1888, the Ministro de Relaciones Exteriores Alberto Elmore (1844-1916) sought to add morning hours to improve services to the public. Palma met with Elmore and discussed several reasons for opposing the measure. He cited the recurrent problems of insufficient resources and staff. Low and often unpaid wages of employees forced several of them to find additional work in the mornings. Palma emphasized that Peru did not have a "public need" for extending library hours because most users were not "real library readers" (verdaderos lectores de biblioteca), but "people with nothing to do" (gente desocupada). ${ }^{280}$ Palma argued that he personally attended to real library users who could always find the library open for them, at every hour and even on holidays. In spite of the director's objections, on March 1, 1888, Elmore expedited a decree that ordered the library open for an additional 3 hours, from 8 to 11 a.m. ${ }^{281}$ Palma sent a letter to the Ministro de Justicia, Arturo García exposing all the points he had verbally made to Elmore. ${ }^{282} \mathrm{He}$ also discussed the issues with President Andres Avelino Cáceres who

\footnotetext{
279 "Reglamento para la Biblioteca y Archivo Nacional" in Memoria que presenta el Director de la Nueva Biblioteca Nacional en el acto solemne de su inauguración el 28 de Julio de 1884 (Lima: Imprenta del Universo de Carlos Prince, 1884), 25.

${ }^{280}$ Palma cited his discussions with Alberto Elmore in one of his written objections. See "Memorandum para el Señor Ministro de Justicia Dr. D. Arturo Garcia [SIC] Rápidas observaciones al decreto Supremo de 1.o de Marzo" Lima March 5, 1888 Legajo 71 Ministerio de Justicia, Culto Beneficencia e Instrucción Fondo RJ Legajo No 71 Instrucción Biblioteca Nacional 1883-1909.

281 "Biblioteca Nacional," Lima, March 1, 1888 in Filiberto Ramírez, Leyes y resoluciones vigentes en materia de instrucción expedidas desde 1876 (Lima: Imprenta y litografía de Peter Bacigalupi \& C.o, 1891), 276 Carlos A. Bazán, August 2, 1888, RJ, Legajo 71 Ministerio de Justicia, Culto, Benefiencia e Instrucción, AGN.

282 "Memorandum para el Señor Ministro de Justicia Dr. D. Arturo Garcia [SIC] Rápidas observaciones al decreto Supremo de 1.o de Marzo."
} 
agreed to suspend the decree. ${ }^{283}$ In 1892, when the Ministerio de Justicia e Instrucción Pública tried to enforce the 1888 decree and published new morning hours, Palma successfully opposed the measure. ${ }^{284}$ A similar episode occurred again in 1896 when legislator Augusto Durand (1870-1923) led efforts to open the library at night. Palma publically opposed the measure in a remitido, disparaging library users and the idea of adding to the work load of employees in order to serve "second rate men of letters" $(Y$ para esos futuros literatos de cajetilla de cigarros se nos ha de imponer recargo de labor?). ${ }^{285}$

Palma also restricted access to some readers of "frivolous novels" and "dull poetry," arguing they confused the national library for those reading rooms and clubs where members could read popular works at a small subscription fee. ${ }^{286}$ For Palma, the mission of the national library consisted of servicing serious people (gente seria) while that of "municipal" or "popular" libraries consisted of providing books to the masses or

\footnotetext{
${ }^{283}$ Palma later described his conversation with Cáceres. See Ricardo Palma to Señor Director del Ministerio de Justicia e Instrucción Pública, Lima, June 8, 1892, RJ, Legajo 71 Ministerio de Justicia, Culto, Benefiencia e Instrucción, AGN.

${ }^{284}$ Ibid. Ignoring Palma's initial objections, the Ministerio de Justicia e Instrucción published the new hours in the director's annual report published between June and early July of 1892, see Ricardo Palma, Memoria del Director de la Biblioteca Nacional correspondiente al Bienio de Julio de 1890 a Julio de 1892 (Lima: Imp. De Torres Aguirre, 1892). The 1888 decree was finally repealed on July 13, 1892, see "Visto el oficio del Director de la biblioteca Y Archivo Nacional...," Lima, July 13, 1892. in RJ, Legajo 71 Ministerio de Justicia, Culto, Benefiencia e Instrucción, AGN.

${ }^{285}$ Ricardo Palma, "Biblioteca Nacional—Señor doctor don Augusto Duránd”, El Comercio (Lima), October 5, 1896.

${ }^{286}$ [novelas frívolas y de versos insustanciales], [gabinetes de lectura por suscricion ó las bibliotecas de Clubs y Casinos]. The librarian needed to present to the "Ministro del ramo" his memoir by July $1^{\text {st }}$ of each year. See Article 7 of the "Reglamento para la Biblioteca Nacional de Lima, May 12, 1879, ADLP. After the War of the Pacific (1879-1883) the government issued some modifications and the memoirs needed to be submitted more symbolically on July $28^{\text {th }}$, Peruvian Independence Day. "Reglamento para la Biblioteca y Archivo Nacional," July 4, 1884, ADLP.
} 
mobs (turba) ${ }^{287}$ He proposed reforming library regulations to grant the director the power to deny certain books to young people and entrance to "rowdy" students (los niños de las escuelas, generalmente díscolos y bulliciosos). ${ }^{288}$ His complaints led to age restrictions in the Reglamento of 1892, which prohibited entrance to people under 15 years of age. Palma also blocked people he presumed to be recreational readers from accessing incunables and other collectible books.

Others shared Palma's elitist vision for the national library and called for the segregation of Lima's readers. Educator and politician Vicente Villarán (1873-1958) noted that if recreational books were denied to library users, two thirds of readers would stop attending. He also disdained the predilection for recreational reading among Peru's youth and their interest in becoming writers (literatos) over men of "science and work." 289 This more exclusive view of the utility of the library conformed closely with conservative views of some of the institution's founders. While they saw the library in utilitarian terms, as a tool for the overall progress of the masses, its services or day-to-day functionality needed to be restricted to a select group of men of letters and science. Teodoro Noel, a member of the Ateneo de Lima, a literary club that met at the library for years, captured elites' hopes of separating Lima's readers:

\footnotetext{
287 “Memorandum para el Señor Ministro de Justicia Dr. D. Arturo Garcia [SIC] Rápidas observaciones al decreto Supremo de 1.o de Marzo" Lima March 5, 1888 Legajo 71 Ministerio de Justicia, Culto Beneficencia e Instrucción Fondo RJ Legajo No 71 Instrucción Biblioteca Nacional 1883-1909.

288 Ricardo Palma, "Reforma reglamentaria" in Memoria que presenta el Director de la Biblioteca Nacional, correspondiente al cuatrenio del 28 de Julio de 1884 al 28 de Julio de 1888" (Lima: Imprenta Masias y Ca., $1888 ?), 12$.

${ }^{289}$ Quoted in Ricardo Palma’s, Memoria, 1900, 7. Original text: “no parece sino que, en nuestra juventud, hubiera más inclinación á ser literatos que hombres de ciencia y de trabajo.” Also see Villarán, Las profesiones liberales.
} 
The Public [library]should only be used by studious men; while the Popular one, similar to a great bazaar, should be the point of reunion for all the proletarian classes, who wishing to study, find in their hours of rest food for their soul or the improvement of their intelligence. The public Library, fulfills its purpose with only owning one issue of any work. Its luxury and wealth lies in its bibliography. The popular one should have numerous editions of instructional texts and industry catalogues and all which can improve the conditions of the laborer, making him familiar with the wonders of the century. The popular one makes men useful to themselves and their like. The public one forms sages and teachers. The public one is a monument in which the intellectual movements of various epochs and generations are sketched, where one goes to admire and enjoy the beauty of the classics. The popular one has the latest formulas on truth, in the distinct branches of human knowledge; it is the free school of the son of the people. Let us establish, then, popular libraries. The school teaches the child: the library instructs the man. Because the instruction that emancipates the soul and breaks the chains of slavery is the fundamental base of progress in modern societies; and this one, you know well, can only be acquired through the school and the book; the teacher and the library. ${ }^{290}$

The notion that a majority of library users were only reading works of literature can be scrutinized based on Palma's own statistics. He often complained that a majority of readers asked for recreational books such as novels and works of poetry. Based on data for 1893, however, probably less than 33 percent of requested books fell under this category, which compiled books of literature and languages under the same subject (see Table 4). His own statistics actually indicate that library users had diverse interests in the subjects of science, history, and political economy. Users consulted encyclopedias and books about technology. In 1894, the percentage of books in the subjects of literature and languages increased to 38 percent (see Table 5). Still, most books constituted diverse categories outside of novels and poetry.

\footnotetext{
${ }^{290}$ Dr. Teodoro Noel in "La Biblioteca: Lectura hecha en el Ateneo, por el Dr. D. Teodoro Noel. Ideas generales sobre la Biblioteca y reflexiones sobre la necesidad y conveniencia de crear bibliotecas populares", El Ateneo de Lima Publicación Quincenal (Lima: Imp. De Torres Aguirre, 1888), 14-15.
} 
Table 4. Books Borrowed by Subject at Lima's National Library in 1893

\begin{tabular}{|l|r|}
\hline Subject & Number of Books \\
\hline Literatura y Lenguas & 3,457 \\
\hline Historia & 2,293 \\
\hline Derecho, Administración y Economía Política & 822 \\
\hline Periódicos & 812 \\
\hline Variedades & 740 \\
\hline Enciclopedia y Tecnología & 559 \\
\hline Geografia y viajes & 524 \\
\hline Ciencias Naturales & 450 \\
\hline Filosofia & 272 \\
\hline Medicina & 255 \\
\hline Bibliografía & 169 \\
\hline Religion & 163 \\
\hline Bellas Artes & 49 \\
\hline Total & 10,614 \\
\hline
\end{tabular}

Source: Ricardo Palma, Memoria que presenta el Director de la Biblioteca Nacional (Lima,1893). 
Table 5. Books Borrowed by Subject at Lima's National Library in 1894

\begin{tabular}{|l|r|}
\hline Subject & Number of Books \\
\hline Literatura y Lenguas & 4,670 \\
\hline Filosofía é Historia & 2,611 \\
\hline Papeles varios y periódicos & 1,747 \\
\hline Jurisprudencia y Administración & 955 \\
\hline Geografía y Viajes & 530 \\
\hline Ciencias Fisica y Matemáticas & 452 \\
\hline Ciencias Naturales & 439 \\
\hline Medicina & 260 \\
\hline Bibliografía y Enciclopedia & 180 \\
\hline Materia religiosa & 170 \\
\hline Milicia y Marina & 123 \\
\hline Bellas Artes y heráldica & 54 \\
\hline Manuscritos & 44 \\
\hline Total & 12,235 \\
\hline
\end{tabular}

Source: Ricardo Palma, Memoria que presenta el Director de la Biblioteca Nacional (Lima,1894).

The library's hours were finally extended between 1905 and 1910, an improvement that Lima's readers appeared to make the most of. ${ }^{291}$ Palma provided irregular statistics for most of his tenure, but we know that during the years that the reading hall functioned from 12 to 5 p.m., readers used between 11 and 12 thousand volumes per year. Data from 1906, 1907, and 1909 show the yearly number of volumes used totaled 14,739; 14,490; and 16,341, respectively. During this time, the minimum number of daily users was 14 while the maximum was 75 . At night, the minimum number of users who visited the library in those years was 9 while the maximum was 47 . In 1911, however, after the municipality of Lima inaugurated its own "nocturnal popular

\footnotetext{
${ }^{291}$ Ricardo Palma, Memoria del director de la Biblioteca Nacional (Lima: Imp. Torres Aguirre, 1905$), 8$.
} 
library," the national library closed its doors to its nightly readers. Palma noted, "Happily, with the creation of the nocturnal Popular Library under the purview and direction of the Honorable Muncipality, a situation so inconvenient for the prestige and mission of the establishment that I manage has come to an end."292

\section{Conclusion}

While the law opened the doors of Peru's national library to all people, San Martín, Monteagudo, Palma, and other elites shared a view of the institution as a space for the erudition of a few men of letters and science. Evidence suggests that the institution remained understaffed and underfunded for most of the nineteenth century, which hindered efforts to extend library hours and provide better services. In spite of its shortcomings, Lima's readers increasingly visited the library. Ricardo Palma's statistics demonstrate they were especially interested in books of literature and poetry, but many also read works of history, law and administration, travel, geography, and science. Given Lima's growing population and literacy rates, a new reading public demanded reforms to extend library hours and implement a checkout system, but they often met with stiff refusals from directors. Demand for reading materials in Lima did not stop at the doorstep of the national library. The following chapter discusses the proliferation of Lima's private bookstores as they began to fill a growing appetite for reading materials and fulfill some of the educational efforts of common teachers, parents and the state.

\footnotetext{
${ }^{292}$ Ricardo Palma, "La Lectura Nocturna," in Memoria del Director de la Biblioteca Nacional (Lima: Sanmarti y Cia, 1911), 6.
} 


\section{CHAPTER III}

Beyond European Literature: Bookstores and the National Textbook and Book Industry, $1850-1900$

On January 1, 1888, French emigré Carlos Prince (1836-1919) launched the first issue of Boletín Bibliográfico, the monthly newspaper organ of his bookstore and printing house in Lima. Through the Boletin, Prince first sought to publicize the titles of the bookstore's collections and other bibliographic articles to a reduced group of merchants and lettered men who could benefit from reading its sophisticated material. ${ }^{293}$ He hoped, however, that the periodical would eventually reach broad circulation in order to fund its costs with advertisements. To reach this goal, Prince distributed the periodical for free to those who requested it at the bookstore. For fourteen years, Prince managed to print four thousand copies per issue. Educational literature listed in the various categories of "Biblioteca Popular," "Enseñanza" and "Manuales" constituted most of the advertised works. ${ }^{294}$ The Boletín also underscored that the bookstore regularly published "national works of history, novels and other books of recreational reading as well as didactic texts" for which the owner offered advantageous contracts to their authors. ${ }^{295}$

The advertisements within the pages of the Boletín Bibliográfico capture the emergence of the publishing industry in Lima and its close relationship to a growing

\footnotetext{
${ }^{293}$ Boletín Bibliografico, Lima, January 1, 1888.

${ }^{294}$ Carlos Prince, Mi estancia de medio siglo en Lima (Lima: Impreso en casa del autor, 1913), 13. In his memoir, Prince notes that he published the periodical for fourteen years. Lima's Biblioteca Nacional has all issues from 1888-1889 and one issue from 1897.

295 Boletín Bibliografico, Lima, January 1, 1888. Original text: "esta Librería edita constantemente obras nacionales de historia, novelas y demás libros de amena lectura; como igualmente, textos de enseñanza, para los cuales hace contratos muy ventajosos para los autores."
} 
demand for educational and national literature. While several of the booksellers who established publishing houses in Lima were foreign-born-including Benito Gil (Spain), Juan Galland and Carlos Prince (France) - they expressed their own fervent nationalism and allegiance to their adoptive country and exploited calls from the government and private educators to develop a national book and textbook industry. Many of the didactic books and textbooks that booksellers chose to edit, publish or advertise were written or compiled by Peruvian authors or immigrants settled in Lima. They also began to include content about the country's history, culture, and geography. Subjects in "popular libraries" or collections of books that targeted the masses addressed local traditions, containing compilations of popular music, cooking recipes, or advice and useful "tips." This literature represented local customs and practices as Peruvian or national, often belying their mixed origins, but connecting individuals to an imagined community in ways the state had failed to do for decades after independence. 296

An analysis of Lima's book and textbook industry helps uncover the attitudes, ideologies and practices as well as processes of formal and informal learning that regulated and influenced everyday life in the capital. Before the advent of the Estado Docente or "Teaching State" of the early twentieth century, urban bookstores began to supply schoolage children and adults with didactic materials. ${ }^{297}$ Their history opens a window into a

\footnotetext{
${ }^{296}$ On the concept of "imagined communities" see Benedict Anderson, Imagined Communities: Reflections on the Origin and Spread of Nationalism (London: Verso, 1983). For a critical view of the concept, particularly for the chronology that pertains to Latin America, see Sara Castro-Klarén and John Charles Chasteen, Beyond Imagined Communities: Reading and Writing the Nation in Nineteenth-Century Latin America (Washington, D.C.: Woodrow Wilson Center Press, 2003).

${ }^{297}$ On the rise of the centralized teaching state in Latin America during the twentieth century see Carlos Newland, "The Estado Docente and Its Expansion: Spanish American Elementary Education, 1900-1950," Journal of Latin American Studies, Vol. 26, No. 2 (May, 1994): 449.
} 
flourishing and ubiquitous, yet understudied print culture that is significant in two important ways. First, educational literature disseminated practical knowledge, shaping the skills of the urban labor force. School textbooks that taught reading, writing and arithmetic reached an estimated 47 to 69 percent of primary school-age children in Lima between 1875 and $1908 .{ }^{298}$ Countless other instructional manuals became available to artisans, teachers, lawyers, and to administrative, agricultural and industrial workers. ${ }^{299}$ Secondly, bookstores helped propagate moral, religious and political ideas that oriented collective identities and cultural norms. These ideas could be found in textbooks and manuals, but also within periodicals, pamphlets, postcards, leaflets, advertisements, novenarios and devocionarios, religious catechicisms, religious paraphernalia, and other objects of "everyday reading" that were sold or distributed for free at bookstores. ${ }^{300}$

The chapter begins with a discussion of Lima's bookstores, educational literature and government efforts to regulate textbooks during the middle of the nineteenth century. These efforts began with the educational code of 1855, but reached more success during the administration of Manuel Pardo and the Civilista Party in the 1870s. The second section examines the proliferation of bookstores after the War of the Pacific (1879-1883), a process

\footnotetext{
${ }^{298}$ Antonio Espinoza, "Libros escolares y educación primaria en la ciudad de Lima durante el siglo XIX, Historica (2007): 137.

${ }^{299}$ Although this chapter opens with a description of manuals and books advertised by Carlos Prince's Boletín Bibliográfico, several other bookstores similarly published full and/or partial catalogues. For Benito Gil's bookstores see Catálogo General de las Librerías de Benito Gil (Lima: Librería e Imprenta Benito Gil, 1886). Bookseller Juan Galland circulated a full catalogue, and a partial catalogue of school textbooks and manuals in his bookstore's newspaper organ, La Escuela Peruana, see "Catálogo de los Textos de Enseñanza de la Librería J. Galland: Proveedora de las Escuelas y Colegios de la República" in La Escuela Peruana, Lima, February 1, 1896. Smaller bookstores and kiosks advertised these manuals and books in weekly magazines. See for example the advertisements "Enrique Gris, Grabador y Librero" and "Kiosko de la Merced (D. M. Ramirez)" in Revista Social, Lima, July 11, 1885.
}

${ }^{300}$ On the concept of "everyday reading" see William Acree, Everyday Reading: Print Culture and Collective Identity in the Río de la Plata, 1780 (Vanderbilt University Press, 2011), 3-4. 
enabled by a growing demand for textbooks with national content. Booksellers capitalized on the national crisis by producing, editing and selling a variety of school textbooks about Peruvian history, geography and civics, which eclipsed the market for European textbooks. The last section discusses the formation of popular libraries, which aggressively targeted Lima's working classes. Through the literature in these libraries, writers and booksellers sought to inspire Peruvian nationalism among popular groups in places beyond the school.

Bookstores, Educational Literature, and Regulation during the Age of Guano

Bricks-and-mortar establishments exclusively dedicated to the sale of books appeared in Lima throughout the first half of the nineteenth century, but they expanded their activities during a period of relative prosperity beginning in the $1840 \mathrm{~s} .{ }^{301}$ During this period, Peru underwent an economic boom as a result of the exploitation of guano, a natural fertilizer formed by bird excrement. The partial state control of the guano industry generated immense revenues for the government, allowing President Ramón Castilla (1797-1867) to negotiate the consolidation of internal and external debt and undertake a series of expensive reforms and public works. He abolished slavery at a cost of 7,651,500 pesos to the state and eliminated the head tax on indigenous Peruvians. The government also helped transform Lima into a cosmopolitan city with imposing new public buildings and parks. During José Balta's presidency (1868-1872), the government accelerated

\footnotetext{
301 The colonial book trade was less the business of exclusive, bricks-and-mortar retail bookshop owners and more the occupation of a variety of merchants who sold miscellaneous items, and of travelers and administrators involved in fulfilling personal requests, see Chapter 1.
} 
railroad construction. ${ }^{302}$ Through public contracts, sinecures, import licenses, speculation, and graft, coastal elites and merchants also secured immense profits from the guano industry. ${ }^{303}$ The economic boom attracted immigrants to Peru, which helped Lima's population soar from about 55,000 shortly after independence to 100,156 in $1876 .^{304}$ Europeans constituted 23 percent of the city's population and along with Eurocentric Peruvians, they demanded imported products and luxuries from the Old World. ${ }^{305}$ Affluent men and women as well as members of a growing class of teachers and writers attended salons (tertulias) where they discussed science, politics, European literature, and the work of other Latin American writers. ${ }^{306}$

In this context, several booksellers established new businesses, capitalizing on a growing demand for European newspapers, books, and literary magazines that catered to the interests of Lima's readerships. The 1860 Guía histórico-descriptiva, administrativa, judicial y de domicilio de Lima listed four bricks-and-mortar exclusive bookstores (see Table 6). ${ }^{307}$ Spanish émigré Benito Gil (1822-1891) established one of these bookstores in

\footnotetext{
${ }^{302}$ Peter Klarén, Peru: Society and Nationhood in the Andes (New York: Oxford University Press, 2000), 161-170. Aslo see Gootenberg, Beetween Silver and Guano, 80-84.

${ }^{303}$ Klarén, Peru: Society and Nationhood in the Andes ,165.

${ }^{304}$ On Lima's population shortly after independence see Klarén, 169; For 1876 Almanaque de “El Comercio" para 1892 (Lima: Imprenta de "El Comercio", 1892), 165.

${ }^{305}$ Ibid, 169.

${ }^{306}$ See Ricardo Palma, Recuerdos de España precedidos de La bohemia de mi tiempo, 1848 á 1860 (Lima: Imprenta La Industria, 1899) and Juana Manuela Gorriti, Obras completas, ed. Alicia Martorell, vol. V Veladas literarias en Lima (Salta, Argentina: Fundación del Banco del Noroeste, 1992).

${ }^{307}$ Manuel A. Fuentes, Guía historico-descriptiva administrative, judicial y de domicilio de Lima (Lima: Librería Central, 1860), 189.
} 
1854. ${ }^{308}$ In the first newspaper advertisements of his Librería Hispano-Francesa, Gil sought the attention of readers by promoting his collection of the latest and most important European books from prominent Spanish and French bookstores. He emphasized the bookstore had a wide range of books about literature as well as textbooks, compilations, and instructional manuals on the various arts and sciences. ${ }^{309}$ Felipe Bailly sold a supply of French and Spanish books. Every two weeks, he received some of the most popular books that were published in Paris as well as various foreign literary and scientific periodicals. The bookstore accepted orders for specific books, scientific instruments and products for stationary shops and printing presses. The establishment of Calleja \& Co. offered mostly books in Spanish with a small selection of French books. ${ }^{310}$ These bookstores reflected a growing demand for books and instruments by an emerging professional and merchant middle class. They were located in the city's busy commercial center where the sale of books, periodicals, desktop and stationary supplies (útiles de escritorio) and other products of everyday business transactions and classroom use would have been on high demand.

\footnotetext{
${ }^{308}$ Benito Gil's approximate birth date is based on his 1877 will; he was fifty-five years old at the time it was written, see Escribano Felix Sotomayor, "Testamento de Benito Gil," 18 January 1877, Folio 477 Indice Terán Tomo iii, 124, Protocolos Notariales, Archivo General de la Nación (AGN), Lima, Peru. According to a receipt issued to Lima's national library in 1884, the bookstore was established in 1854 . See "Librería Universal de Benito Gil," Legajo 71, Biblioteca Nacional 1883-1909, Ministerio de Justicia Culto, Beneficencia e Instrucción (RJ), AGN, Lima, Peru.

${ }^{309}$ See "Libreria Hispano Francesa," El Comercio (Lima), July 9, 1858. The advertisement can be found in Guía de Domicilio de Lima para el año 1864 (Lima: Imprenta del Autor Administrada por Carlos Prince, 1863).

${ }^{310}$ Ibid.
} 
Table 6. Lima's Bookstores in 1860

\begin{tabular}{|l|l|l|}
\hline Library & Owner & Address \\
\hline Librería Central & D. Felipe Bailly & $\begin{array}{l}\text { Portal de Botoneros, } \\
196\end{array}$ \\
\hline Librería Española & Calleja y C.a & $\begin{array}{l}\text { Calle del Correo Viejo, } \\
155\end{array}$ \\
\hline $\begin{array}{l}\text { Librería Francesa y } \\
\text { Española }\end{array}$ & D. Benito Gil & $\begin{array}{l}\text { Calle de Bodegones, } \\
160\end{array}$ \\
\hline $\begin{array}{l}\text { Librería Francesa y } \\
\text { Española }\end{array}$ & D. José María Masias & Calle de Pescadería, 127 \\
\hline
\end{tabular}

Source: Guía histórico-descriptiva, administrativa, judicial y de domicilio de Lima (Lima: Librería Central, 1860).

The supply of European textbooks in Lima's bookstores during the first half of the nineteenth century mostly reflected the preferences of teachers and local authorities since few directives from the national government appeared before $1855 .{ }^{311} \mathrm{In}$ fact, before that year, the national government had only sanctioned the use of four specific textbooks at all school levels. They included Antonio González's, Catecismo político para la primera enseñanza de las escuelas de la república del Perú in 1825; Chilean Andres Bello’s compilation, Principios de Derecho de Gentes in 1835; José María Pérez Vargas's text on Latin grammar based on the work of Antonio de Nebrija in 1841; and José Nieto's, Catecismo de los derechos del hombre en Sociedad extractado de varios autores in 1843. ${ }^{312}$ In 1840, hoping schools could train better and more uniform writers, the central

\footnotetext{
${ }^{311}$ One of the few laws addressing the use of school textbooks in general during the early republican period was passed in 1833. It stated that parents "shall provide students with the books chosen by their teachers" (los padres de los escolares les proporcionarán los libros que los preceptores les designen); see "Determinando las materias que deben ensenarse en las escuelas gratuitas de la capital de Lima" in Oviedo, Colección de Leyes, Decretos y Ordenes publicadas en el Perú desde al año 1821 hasta el 31 de diciembre de 1859 (Lima: Felipe Bailly, 1862), 18.

312 Oviedo, Colección de Leyes, 120. Historian Antonio Espinoza cited Antonio González's, Catecismo político para la primera enseñanza de las escuelas de la república del Perú as approved by Simón Bolivar in 1825, see Antonio Espinoza, "Libros escolares y educación primaria en la ciudad de Lima durante el siglo XIX,” Histórica, XXXI.1 (2007): 135-170.
} 
government also ordered that public schools adopt a method of writing (rather than a specific book) based on the work of Spanish writers Javier de Santiago y Palomares and Torcuato Torío de la Riva y Herrero. ${ }^{313}$ A general education code issued in 1850 only reinforced local autonomy, leaving decisions about the use of specific textbooks and authors up to teachers and "educational boards" (juntas de instrucción). ${ }^{314}$

Constitutional provisions guaranteeing freedom of the press coupled with the lack of government regulation of school textbooks resulted in the proliferation of small printing houses (imprentillas) and the multiplication of varied educational literature used in schools. As discussed in chapter one, much of this literature constituted compilations and translations of European books. Imprentillas operated on a small scale and usually with one hand press. They printed administrative documents, lottery tickets, receipts, and songs, as well as hagiographies, which were often used as reading books for children. ${ }^{315}$ These small businesses probably printed the thousands of elementary school books described, but not listed in Felipe Paz Soldan's Biblioteca Peruana (1879). In his section on education, the bibliographer warned that he was excluding thousands of elementary books (cartillas,

\footnotetext{
313 Oviedo, Colección de Leyes, 120.

314 “Reglamento general de instrucción pública,” June 14, 1850 in Oviedo, Colección de Leyes, 228.

${ }^{315}$ Eugenia Roldán Vera, The British Book Trade and Spanish American Independence: Education and Knowledge Transmission in Transcontinental Perspective (Ashgate, 2003), 16.
} 
catones, catecismos, and silabarios) destined for the instruction of children. ${ }^{316}$ Some teachers resorted to hand copying or handwriting their own textbooks. ${ }^{317}$

In 1855 and with Castilla's pragmatic support, an ascendant coterie of liberal reformers sought to address the lack of uniformity in Peruvian schools and the deficiencies of the code issued only five years earlier. The new code charged a central governmental body — the Dirección General de Estudios (DGE) — with both authorizing and promoting the publication of new primary school textbooks. Article 8 also expressed that the DGE needed to facilitate the circulation of books at cost prices and ensure that their authors were properly remunerated. ${ }^{318}$ Reformers hoped to standardize education by delineating the subjects to be studied as part of a national program of "popular instruction" to be taught in early childhood (infancia), elementary (primeras letras), normal and artisan (de artes) schools. Elementary schools, which taught the first two to four years of schooling, were required to teach at a minimum, lessons in religion, civics, reading, writing, practical arithmetic, and elementary grammar (nociones de Gramática Castellana). ${ }^{319}$ Article 16 added the subjects of social etiquette (reglas de urbanidad), hygiene, domestic economy, geography, and the history of Peru. It also ordered the teaching of practical subjects, which

\footnotetext{
${ }^{316}$ Mariano Felipe Paz Soldan, Biblioteca Peruana (Lima: Imprenta Liberal, 1879), 506. Original text: "Advertencia-Este Capítulo comprende las publicaciones que se refieren á la enseñanza de las Ciencias, Artes y Oficios. Los Discursos, Memorias de los Rectores ó Directores y Profesores de las Universidades y de establecimientos de Instrucción. Las Memorias de los Rectores de Colegios y lo relativo á la enseñanza. El Capitulo XIII Ciencias sirve de complemento al presente. Se ha omitido millares de publicaciones destinadas á la instrucción de los niños de escuelas como Cartillas, Catanes, Catecismos, Silavarios \&."

${ }^{317}$ For example, José María Echenique, Compendio de la Aritmética Para la instrucción de la Juventud (Piura, 1841).

${ }^{318}$ See Article 8 in the "Reglamento de Instrucción Pública," April 7, 1855, Archivo Digital de la Legislación del Perú (ADLP), http://www.leyes.congreso.gob.pe/Documentos/LeyesXIX/1855033.pdf.

${ }^{319}$ Ibid, Article 17.
} 
included elementary geometry, physics, chemistry and natural history "as applied to the popular arts and agriculture," as well as bookkeeping, drawing, music, and pedagogy. ${ }^{320}$

The stipulation enhancing the role of the national government in evaluating school textbooks prompted the approval of twelve additional textbooks between 1855 and 1859 and twenty more between 1860 and $1869 .{ }^{321}$ Several of these books addressed subjects already instituted in most of Lima's elementary schools including three about grammar, two on arithmetic, two on religion, and one on reading. The DGE approved one textbook on civics-Francisco González de Paula Vigil's Catecismo patriótico - but the subject remained neglected in most of Lima's schools. ${ }^{322}$ The books addressing newly approved subjects included two on Peruvian geography and one on hygiene. Four of the books approved during this period were edited in Lima, one in Callao near Lima, and one in the northwest city of Chiclayo. Four more books on the subjects of religion, grammar and arithmetic by José María Pérez appeared to have been edited in the southcentral city of Arequipa. Pérez received support from the federal government, which ordered the printing of 10 thousand copies and set the price of the books at 2 reales. ${ }^{323}$ The books published the

\footnotetext{
${ }^{320}$ Ibid, Article 16. Original text: “nociones de Geometría, Física, Quimica, é Historia Natural aplicadas á las artes communes y al cultivo del campo."

${ }^{321}$ Memoria que presenta el ministro de justicia, instrucción y culto al congreso ordinario de 1901 (Lima: Imprenta del Estado, 1901), 868.15-868.21. "Secretaria del Consejo Superior de Instrucción PúblicaRazón de los textos aprobados desde 1855 hasta la fecha" in El Faro (Lima) December 16, 1889; January 1, 1890; and February 16, 1890. Missing titles in El Faro and the 1901 Memoria can be found in "Inserciones Relacion de los textos aprobados por el Consejo Superior de Instrucción cuya autorización está vigente," El Comercio (Lima), October 29, 1897.

${ }^{322}$ On the subjects instituted in Lima's schools, see Espinoza, "Libros escolares y educación primaria en Lima durante el siglo XIX", 154-161.

${ }^{323}$ José María Pérez's books appear as three textbooks in "Adoptando por texto para la enseñanza popular unos cuadernos escritos por el Dr. D. José María Pérez," August 18, 1855 (ADLP). On official lists, the religious text is divided into two, one as "Historia sagrada" and one as "Doctrina Cristiana," see footnote 29. Around this time, one peso usually equaled 8 reales, see Christine Hunefeldt, Liberalism in the
} 
following decade similarly addressed traditional subjects. Only six of the twenty books approved during the 1860s addressed new subjects, four on history, one on geography, and one on bookkeeping. Most of the books, however, were edited by Peruvian authors established in the city of Lima such as educators Antonio Larrañaga and Manuel Salazar, and writer-journalist and statistician Manuel Atanasio Fuentes. ${ }^{324}$

Despite some progress in the production and approval of new school textbooks, efforts to homogenize education through the 1855 school code and increased oversight of the central government failed to materialize through the 1860 s. Congress and various leaders issued additional isolated decrees, some contradicting one another, causing confusion among teachers and local authorities. ${ }^{325}$ One decree, issued under the liberal administration of Mariano Ignacio Prado (1865-68), suppressed the DGE, which had overseen the approval of textbooks. Prado also issued a new primary school code that continued to provide local authorities broad discretion on curricular decisions. ${ }^{326}$ José

Bedroom: Quarreling Spouses in Nineteenth-Century Lima (The Pennsylvania State University Press, 2000), XIX.

${ }^{324}$ Larrañaga published several books in Lima and lived in the capital since at least 1864, see "Matrícula de los abogados inscritos en la corte de Lima" in Memoria que presenta el Ministro de Estado en el Departamento de Justicia, Instrucción Pública, Beneficencia y Culto al Congreso Nacional de 1864 (Lima: Imprenta del Estado, 1864). Salazar had a lengthy career in education in Lima as professor of the Colegio de Guadalupe and the University of San Marcos. In the 1870s, he founded the Partido Civil along with Manuel Pardo, see Espinoza, "Libros Escolares," 164. Fuentes was a notable lawyer and writer, well known in Lima's lettered circles for his journalistic activities and statistical work. He also wrote several educational works including Elementos de higiene privada, extractados de varios autores (Lima: M. N. Corpancho, 1859), Compendio de Historia Santa (Lima, 1868), and Catecismo de economía política (Lima: Impr. Del Estado, 1876). During the 1860s, Fuentes reorganized and administered the official Imprenta del Estado.

${ }^{325}$ Memoria que El Ministerio de Estado en el Despacho de Instrucción, Culto, Justicia y Beneficencia presenta al Congreso Nacional de 1874 (Lima: Imprenta del Universo, de Carlos Prince, 1874), XLV.

${ }^{326}$ See Mariano Ignacio Prado, “A los prefectos y alcaldes municipales,” June 27, 1866 in Memoria del Secretario de estado en el Despacho de Justicia, Instrucción Publica, Culto y Beneficencia presentada al Congreso Constituyente de 1867 (Lima: Imprenta de "El Progreso," 1867), XVI-XVIII. 
Balta, who became president of Peru after leading a provincial revolt against Prado's liberal government in Lima in 1868, replaced the DGE with the Consejo Superior de Instrucción Pública (CSIP) in May of $1869 .{ }^{327}$ In its organizational phase, the council only approved two books, one in 1870 and two in 1871. Some confusion over its duties led to a resolution confirming the council's role in the approval of books in $1871 . .^{328}$

The platform of Manuel Pardo (1834-1878) and his Civilista Party-the first civilian administration of Peru—partly rested on expanding, improving, and homogenizing an educational system that had been administered by municipalities for decades. They passed the more comprehensive Reglamento General de Instrucción Pública of $1876 .{ }^{329}$ The law reorganized the CSIP, requiring that the members include the Minister of Education as president and the Director of Popular Instruction as secretary, as well as two faculty members of the University of San Marcos, two secondary school teachers, two primary school teachers and two private school teachers. It is worth noting that the first article describing the responsibilities of the council addressed the authorization of textbooks for elementary and secondary education. Moreover, previous legislation dealing with textbooks had simply ordered that the DGE or later, the CSIP approve textbooks, but

\footnotetext{
${ }^{327}$ See "Suprimiendo la Dirección General de Estudios y el Archivo Nacional, asimismo modificando el sueldo del Director del Museo Nacional, November 29, 1865 and Memoria que presenta el Ministerio de Estado en el Departamento de Justicia, Culto, Insturcción y Beneficencia Al Congreso Nacional de 1870 (Lima: Imprenta de Juan N. Infantas, 1870), 5.

${ }^{328}$ See "Resoluciones Supremas" in Legislación Municipal Compilación de leyes y resoluciones para el Régimen de Administración local de los Consejos de la República 1873 á 1876 (Lima: Imprenta del Estado, 1876), 95.

${ }^{329}$ Composed of 349 articles, it exceeded the preceding law by 269 more provisions. Reglamento General de Instrucción Pública del Perú, March 18, 1876.

http://www.leyes.congreso.gob.pe/Documentos/LeyesXIX/1876041.pdf
} 
none of the laws had excluded the use of unapproved books in public schools. In 1876, a law clarified that teachers could only teach using books approved by the CSIP. ${ }^{330}$ Under the newly formed CSIP, the list of approved books grew by 44 more between 1870 and 1879. ${ }^{331}$

Several provisions regarding the production and circulation of textbooks and other didactic materials surpassed the goals of the 1850 and 1855 educational codes. The 1876 code mandated that primary schools teaching the second grade form libraries with books for the instruction of children. Previously, only colegios were required to have such libraries. The new law also specified that in addition to holding books about morality, school libraries needed to include books about scientific education, literature and the mechanical arts. In an effort to democratize education, the law dictated that poor children attending "first grade schools" were entitled to free books and school supplies. ${ }^{332}$ Other provisions specified that books, along with medals and honorable mentions, should be used as prizes to encourage educational achievement.

The Civilistas also favored the production of pedagogical literature and the educational textbooks and projects of some private teachers. They funded the works of inventor and educator Arnaldo Márquez (1832-1903), who founded and edited the pedagogical newspaper El Educador Popular. ${ }^{333}$ In many ways, El Educador Popular

\footnotetext{
${ }^{330}$ See "Resoluciones Supremas" in Legislación Municipal Compilación de leyes y resoluciones para el Régimen de Administración local de los Consejos de la República 1873 á 1876 (Lima: Imprenta del Estado, 1876), 95.

${ }^{331}$ See footnote 29.

332 First grade schools or Escuelas de primer grado only taught the first two years of primary education which generally encompassed the subjects of reading, writing and arithmetic.

${ }^{333}$ El Educador Popular (New York), May 15, 1873.
} 
epitomized the Eurocentric print culture of the first half of the nineteenth century. Published in New York with the help of several Latin American collaborators, it compiled, translated and disseminated the work of various European and American pedagogues. For the first time, however, the government took steps to supply teachers with continuous pedagogical literature. It distributed copies of the periodical to Peru's municipalities between 1873 and 1877.334 From New York, Márquez also wrote a series of pedagogical manuals that were approved by the CSIP. The central government also later funded the Boletín de Instrucción Pública, a monthly periodical founded by educator Isabel Bressler. The Boletín de Instrucción Pública received contributions from Lima's local educators including Agustin La Rosa Toro, Enrique Benites and Sebastián Lorente. The editor included educational decrees and laws as well as articles about education. It was published for four years by the government's Imprenta del Estado. The Dirección General de Instrucción subscribed to 50 issues and ordered they be distributed among members of congress, the university and various colegios. ${ }^{335}$

The educational code of 1855 also addressed so-called "popular libraries" (bibliotecas populares). Article 89 called for the creation of popular libraries or centers of alternative learning for the popular classes. In the elite imaginary, popular libraries would be for starkly different readerships than those of the already established Biblioteca

\footnotetext{
${ }^{334}$ El Educador Popular (New York), April 30, 1877.

${ }^{335}$ Mariano Felipe Paz Soldán, Biblioteca peruana, 9. El Comercio, January 3, 1878. According to another article from El Comercio, the Bressler and her husband continued the publication after the War of the Pacific. By 1886, they were publishing the periodical from Paris, renamed it "Boletin de Instruccion Publica "Revista Quincenal ilustrada dedicada a España y las republicas centro y sudamericanas. Teachers in Lima could subscribe from the Libreria Clasica y Cientifica. See "Boletín de instrucción pública" in $E l$ Comercio (Lima), June 19, 1886.
} 
Nacional, discussed in the previous chapter. The first would be centers for recreational reading, but more importantly, for learning diverse practical subjects deemed appropriate for the popular classes. Popular libraries did not need copies of complex, scholarly works, but several copies of abridged and simplified texts. The creation of popular libraries would allow for the Biblioteca Nacional to function more effectively as a center for elite erudition where trusted men of science could consult complex books and the nation's historical, material treasures. ${ }^{336}$

Although plans for creating popular libraries failed to materialize, several more private bookstores and printing houses appeared in Lima during the 1870s, fulfilling at least some of the educational objectives of the Civilista Party and meeting some of the growing demand for educational literature. In 1876, the number of bookstores in Lima grew to at least twelve or 1 for every 6,260 inhabitants. No less than thirteen printing houses as well as stationary shops and businesses listed under lithography also offered printing services or books for sale. ${ }^{337}$ Benito Gil, who had established his bookstore in 1854 , incorporated a printing house to his business. Initially, he had focused on importing Spanish and French books, but during the 1870s, he began to edit and publish instructional

\footnotetext{
${ }^{336}$ Repeatedly, Ricardo Palma differentiates between the mission of the Biblioteca Nacional which is to provide researchers and university students only with a place of study and the practices of reading popular literature in the "bibliotecas de Clubs y Casinos" in his Memorias de la Biblioteca Nacional printed between 1884 and 1911. See for example Ricardo Palma, Memoria que presenta el Director de la Biblioteca Nacional correspondiente al Cuatrenio del 28 de Julio de 1884 al 28 de Julio de 1888 (Lima: Imprenta Masías y Ca., 1888). This view is also detailed by Dr. Teodoro Noel in "La Biblioteca: Lectura hecha en el Ateneo, por el Dr. D. Teodoro Noel. Ideas generales sobre la Biblioteca y reflexiones sobre la necesidad y conveniencia de crear bibliotecas populares", El Ateneo de Lima Publicación Quincenal (Lima: Imp. De Torres Aguirre, 1888), 14.

${ }^{337}$ For 1876 data on bookstores, see op. cited Almanaque del comercio de Lima 1876, 181. Lima had a population of 100, 156 in 1876 and 103, 556 in 1891, according to Almanaque de "El Comercio" para 1892 (Lima: Imprenta de “El Comercio", 1892), 165.
} 
reading materials and textbooks written by Lima's teachers and writers. Gil even rebranded his bookstore as Librería Universal, a name that no longer conveyed the European origins of many of the books in his collections. ${ }^{338}$ Notedly, Gil reedited many of the books written by fellow Spanish émigré to Peru Sebastian Lorente. ${ }^{339}$ In 1876, Gil solicited the government for approval of several of Lorente's books. ${ }^{340}$ Eleven of Lorente's books were approved that year alone. In the following decades, Gil would publish the works of many other local teachers and writers including those of Manuel M. Salazar, A. T. Whilar, Miguel Antonio de la Lama, José Luis Torres, Máximo Vázquez, José Francisco Maticorena, Artidoro García Godos, Leopoldo Arosemena, and others. ${ }^{341}$ An impending economic crisis in 1877, the assassination of President Manuel Pardo in 1878 and Peru's catastrophic military defeat in the War of the Pacific (1879-1883) halted

\footnotetext{
${ }^{338}$ Gil began using "Librería Universal" as the name of his publishing house in 1968, see for example Jean Joseph Gaume, Compendio abreviado del catecismo de perseverancia para el uso de los niños (Lima: Librería Universal, 1868), Fondo Antiguo, BNP, Lima, Perú. An 1878 advertisement in El Comercio used "Librería Universal" over the previous "Librería Hispano-Francesa," see "Librería Universal de Benito Gil,” El Comercio (Lima), February 9, 1878.

${ }^{339}$ Some of the titles by Sebastian Lorente included Historia del Perú bajo la dinastía austríaca, 15421598 (Lima: Benito Gil, 1863), Primeras lecciones de geografía astronómica: para el Colegio de Guadalupe (Lima: Benito Gil, 1865), Catecismo histórico de la doctrina cristiana para el colegio Guadalupe (Lima: Libr. de Benito Gil, 1865), available in Fondo Antiguo, BNP, Lima, Perú.

${ }^{340}$ Filiberto Ramírez, Leyes y resoluciones vigentes en materia de Instrucción expedidas desde 1876 (Lima: Imprenta y Litografía de Peter Bacigalupi \& C.o, 1891), 104.

${ }^{341}$ Manuel M. Salazar, Gramática castellana para los colegios de instrucción media (Lima: Benito Gil, 1871); A. T. Whilar, Curso teórico-práctico de gramática castellana según el novísimo método seguido por los mas notables gramáticos alemanes, franceses, ingleses y norteamericanos (Lima: Benito Gil, 1888); Miguel Antonio de la Lama, Catón Cívico (Lima: Benito Gil, 1889); José Luis Torres, Catecismo patriótico y los mártires (Lima: Benito Gil, 1893); Máximo Vázquez, Estudio de la constitución peruana para los cursantes del segundo grado de instrucción media y para los ciudadanos en general (Lima: Benito Gil, 1899); José Francisco Maticorena, Compendio de Geografía Universal (Lima, Benito Gil, 1899); Artidoro García Godos, Compendio de aritmética práctica conforme al programa oficial para uso de los alumnos de instrucción primaria de primer y segundo grado (Lima: Benito Gil, 1896), Fondo Antiguo, BNP, Lima, Perú.
} 
the educational agenda of the Civilista Party as well as the projects of various writers and educators, broadly disrupting Lima's bustling print culture. The invading army targeted government buildings, printing houses, and especially, various educational establishments. 342 They looted the libraries of the Colegio de San Carlos, Escuela de Minas, Escuela de Medicina, Escuela de Artes y Oficios, and Colegio Militar, taking valuable books, machinery, educational and scientific instruments, and furniture. Less valuable items were sold at cheap prices by street vendors. ${ }^{343}$ Once looted, the Chileans used government and school buildings as army barracks. Further disrupting educational activities, Peruvian authorities were forced to cancel funding of several municipal schools in order cover some of the costs of the War. ${ }^{344}$

The Imprenta del Estado and other privately-owned printing houses, which had produced various educational publications, also became wartime booty. ${ }^{345}$ Chilean businessmen Isidoro Errázuris and his associate Luis E. Castro, who had recently lost their own printing business to a fire in Valparaiso, stole valuable steam-printing presses, movable type, paper, and other stationary supplies and sent them to Chile in order to reestablish their printing house. During the occupation of Lima, which lasted through October of 1883, Chileans restricted and censored Peruvian publications, only allowing the

\footnotetext{
${ }^{342}$ Felipe Paz Soldan, Guerra de Chile contra el Perú y Bolivia (Buenos Aires: Imprenta y Librería de Mayo, 1884), 700.

${ }^{343}$ Ibid.

${ }^{344}$ Espinoza, Education and the State in Modern Peru, 28.

${ }^{345}$ Felipe Paz Soldan, Guerra de Chile contra el Perú y Bolivia, 701. Chilean Admiral Patricio Lynch corroborated Paz Soldán's account of the looting of the Imprenta del Estado and the printing house of the newspaper La Patria in Memoria que el Contra-Almirante D. Patricio Lynch Jeneral en Jefe del Ejercito de Operaciones en el Norte del Perú presenta Al Supremo Gobierno de Chile (Lima: Imprenta Calle 7 de Junin Num. 255, 1882), 76-148.
} 
operation of a handful of newspapers that supported the Chilean-backed government of Miguel Iglesias. They included La Actualidad, La Situación, El Diario Oficial and El Comercio. Lima's 1887 directory for the city did not list any bookstores although some stationary shops operated through the war years. ${ }^{346}$ Not surprisingly, the CSIP only managed to approve ten school textbooks during the 1880 s, all of which were added to official lists after the Chileans left the capital. ${ }^{347}$

Textbook and Nation in the Postwar Years

The bourgeoning publishing industry and book commerce of the prewar years began to recover in the 1890 s. Lima's directory of 1898 listed 8 bookstores. ${ }^{348}$ By 1910 , the number of bookstores grew to thirteen, with seven operating their own publishing houses and making more periodicals, newspapers and books available to more people. ${ }^{349}$ The proportion of bookstores to inhabitants in Lima approximated that of other Latin American capitals by the turn of the nineteenth century. Although in 1876 Lima had a ratio of 1 bookstore for every 6,260 inhabitants, it changed to 1 per 12,995 inhabitants in the years following the devastating War of the Pacific. ${ }^{350}$ By the turn of the century, however,

\footnotetext{
${ }^{346}$ Gaston Soto y Ramirez, Guía de domicilio é industrial de Lima y Comercial de las provincias del Callao y Huancayo correspondiente al año 1887, 151-173.

347 See footnote 29.

${ }^{348}$ Carlos B. Cisneros y Rómulo E. García, Guía Ilustrada de Lima, El Callao y sus alrededores, 184.

${ }^{349}$ Directorio Anual del Perú para 1910 (Lima: Imprenta del Estado, 1910), 499-500.

${ }^{350}$ For data on1876 see footnote 45. Lima had a population of 100, 156 in 1876 and 103, 556 in 1891 , according to Almanaque de "El Comercio" para 1892 (Lima: Imprenta de "El Comercio", 1892), 165. For information on bookstores after the War of the Pacific see footnote 51.
} 
Lima had about 1 bookstore for every 10, 837 people. ${ }^{351}$ With a population that hovered around 120,000 people in 1898, Bogotá had no less than 1 bookstore for every 10,000 people. ${ }^{352}$ In 1896, the city of Quito, Ecuador with a population of 80,000 had at least 9 bookstores or 1 bookstore for every 8,888 residents. ${ }^{353}$ These ratios compare unfavorably to those of European cities like Brandenburg and Berlin where there was a bookshop for every 3,700 inhabitants in 1913 , or to Paris, which had achieved a ratio of 1 to 2,000 in the middle of the nineteenth century. ${ }^{354}$ We know, however, that stationary shops, printing houses and newspaper agencies also advertised the sale of a wide range of textbooks, manuals and religious books. Moreover, second hand books were also sold by street vendors and mercados.

Authors seeking to publish educational content had many more options by the last decades of the nineteenth century. In addition to publishing their work with Benito Gil, they could also use the services of Carlos Prince, who offered "advantageous publishing

\footnotetext{
${ }^{351}$ Lima's total population in 1908 was 140, 884 according to the Censo de la provincia de Lima (Lima: Impr. De "La Opinión Nacional, 1915), 381, Colección Especial, Biblioteca Central "Luis Angel Cisneros," Pontificia Universidad Católica del Perú, Lima, Peru. For bookstores, see op. cited E. Paulet, Directorio Annual del Perú para 1910, 499-500.

${ }^{352}$ Ibid, 84. According to Palau's 1898 directory, Bogotá had over 120,000 people. The 1912 census puts the city's total population at 121, 257. See Pedro M. Carreño, Censo General de la República de Colombia levantado el 5 de Marzo de 1912 (Bogotá: Imprenta Nacional, 1912), 334, Libros Raros y Manuscritos, BLAA, Bogotá, Colombia. During the nineteenth century, Colombia underwent various constitutional changes which rearranged the country's territory and population, a process that complicates a more accurate estimate of Bogotá's population. Also see Germán Rodrigo Mejía Pavony, Los años del cambio. Historia urbana de Bogotá, 1820-1910 (Bogotá, CEJA, 2000), 287-288.

${ }^{353}$ Adolfo Giménez, Guía Topográfica, Estadística, Política, Industrial, Mercantil y de Domicilios de la Ciudad de Quito con las efemérides, anales históricos y acontecimientos mas notables hasta el año 1862 (Quito: Tipografía de la Escuela de Artes y Oficios, 1894), 165 and 245. 165, https://archive.org/details/guatopogrficaes00jimgoog.

${ }^{354}$ Lyons, Martyn, A History of Reading and Writing in the Western World (Palgrave Macmillan, 2010), 150.
} 
contracts" for the authors of school textbooks. ${ }^{355}$ Librería San Pedro specialized in selling religious paraphernalia and catechisms, but still published three out of the four textbooks by teacher and writer Teresa González de Fanning (1836-1918). ${ }^{356}$ Alternatively, writers could publish their work with the bookstore and publishing house of another French emigré Juan Galland, who advertised his business as the "provider of school textbooks and materials of the republic." 357 The bookstore's periodical La Escuela Peruana emphasized Galland's interest in publishing more textbooks written by national authors and for teaching the Peruvian masses. ${ }^{358}$ The expansion of the textbook industry reflected on the number of books the CSIP was able to approve in the postwar years. Between 1890 and 1899, the CSIP approved 119 books - a figure that totaled more books than the combined number of approved books in the previous four decades. ${ }^{359}$

According to contemporaries, Galland transformed the book trade in Lima, especially in its relation to popular education. ${ }^{360}$ Unlike other book merchants who only

\footnotetext{
${ }^{355}$ Boletín Bibliográfico (Lima), January 1, 1888, Revistas Antiguas de Lima, Hemeroteca, BNP, Lima, Perú.

${ }^{356}$ See Teresa González de Fanning, Lecciones de economía doméstica (Lima: Imprenta y Librería San Pedro, 1893), Lecciones de Historia Santa (Lima: Imprenta y Librería San Pedro, 1894) and Lecciones de Geografía (Lima: Imprenta y Librería de San Pedro, 1897).

357 The original text stated "Casa Proveedora de los Colegios y Escuelas de la República" in La Escuela Peruana (Lima), March 1, 1896, Revistas Antiguas de Lima, Hemeroteca, BNP, Lima, Perú and "proveedora de las escuelas y colegios de la república, premiada con medallas de oro (certamen escolar de 1889 y exposición nacional 1892)" in El Hogar: Semanario Para Las Familias, Lima November 17, 1895 Ano 1, num 26, 416.

358 “La exposición del 92," La Escuela Peruana (Lima), May 1, 1892, Revistas Antiguas de Lima, Hemeroteca, BNP, Lima, Perú.

${ }^{359}$ See footnote 29.12 books were approved between 1850 and 1859, 20 between 1860 and 1869, 44 between 1870 and 1879 and 10 between 1880 and 1889 .

360 "Rasgos biográficos" La Escuela Peruana, Lima, September 1, 1892, Año 1, No. 6, 134
} 
focused on selling to urban customers in Lima, Galland contacted the municipalities of other Peruvian provinces in order to supply them with educational materials. Various provinces increasingly sent their own representatives in order to choose and make orders of school materials from the newly established bookstore. ${ }^{361}$ Part of the textbook selection of his bookstore was reprinted twice a month in the issues of La Escuela Peruana, edited by Galland and educators, Manuel O. Suarez and Armando Filomeno. Books authored by Filomeno and Suarez often appeared in these lists along with other books edited by the Librería Galland and approved by the CSIP. After Galland's death, his widow Maria R. Galland took over the operations of the bookstore and publishing house. In 1896, when she requested the state subscribe to the periodical, the CSIP agreed to subscribe to 1,200 copies each month. ${ }^{362}$

The editors of La Escuela Peruana produced their own Libro de lectura which they advertised as approved by the CSIP and as the only Peruvian reading book with national content. The price for the book was only 40 cents, and it had at least two editions. According to the editors, the first sold out in two years. They published a second augmented and corrected edition of the same book. The second edition included the acta de la jura de la Independencia, the Peruvian national anthem, some of Bolivar's writings and various pieces about the War of the Pacific. Prior to the war, most reading books had been translations of foreign texts. ${ }^{363}$ Teachers increasingly argued against the use of these texts

\footnotetext{
361 Ibid.

${ }^{362}$ Memoria presentada por el Ministro de Justicia, Culto é Instrucción al Congreso Ordinario de 1896 (Lima: Imprenta de Torres Aguirre, 1896), 396-98.

363 “En Venta la Segunda Edición del Libro de Lectura de 'La Escuela Peruana”, La Escuela Peruana, Lima, August 1, 1895.
} 
because they tended to promote foreign rather than Peruvian nationalism. Furthermore, modern pedagogical methods prescribed the use of familiar content when teaching reading, writing, geography, arithmetic, and the sciences. ${ }^{364}$ For instance, when teaching arithmetic, teachers called for books to use the metric system and the national coin. New methods also called for subjects to be integrated, which the Libro de lectura did by including scientific writings, literary compositions as well as moralistic maxims in a reading book (See Figure $1)$.

\footnotetext{
${ }^{364}$ Peruvian educators echoed the calls of naturalistic educators who recommended that school subjects be simplified through the use of the child's immediate environment. These ideas can be traced to Comenius and Rousseau, but are further detailed in the work of Pestalozzi. On naturalistic pedagogy see Gerald L. Gutek, Historical and Philosophical Foundations of Education: A biographical Introduction (Columbus, Ohio: Merrill, 1997), 4-7. On Peruvian efforts to implement naturalist pedagogy see "Plan de Estudios" and "Libros de Texto" in La Escuela Peruana, Lima, June 1, 1895.
} 
Figure 1. Libro de Lectura

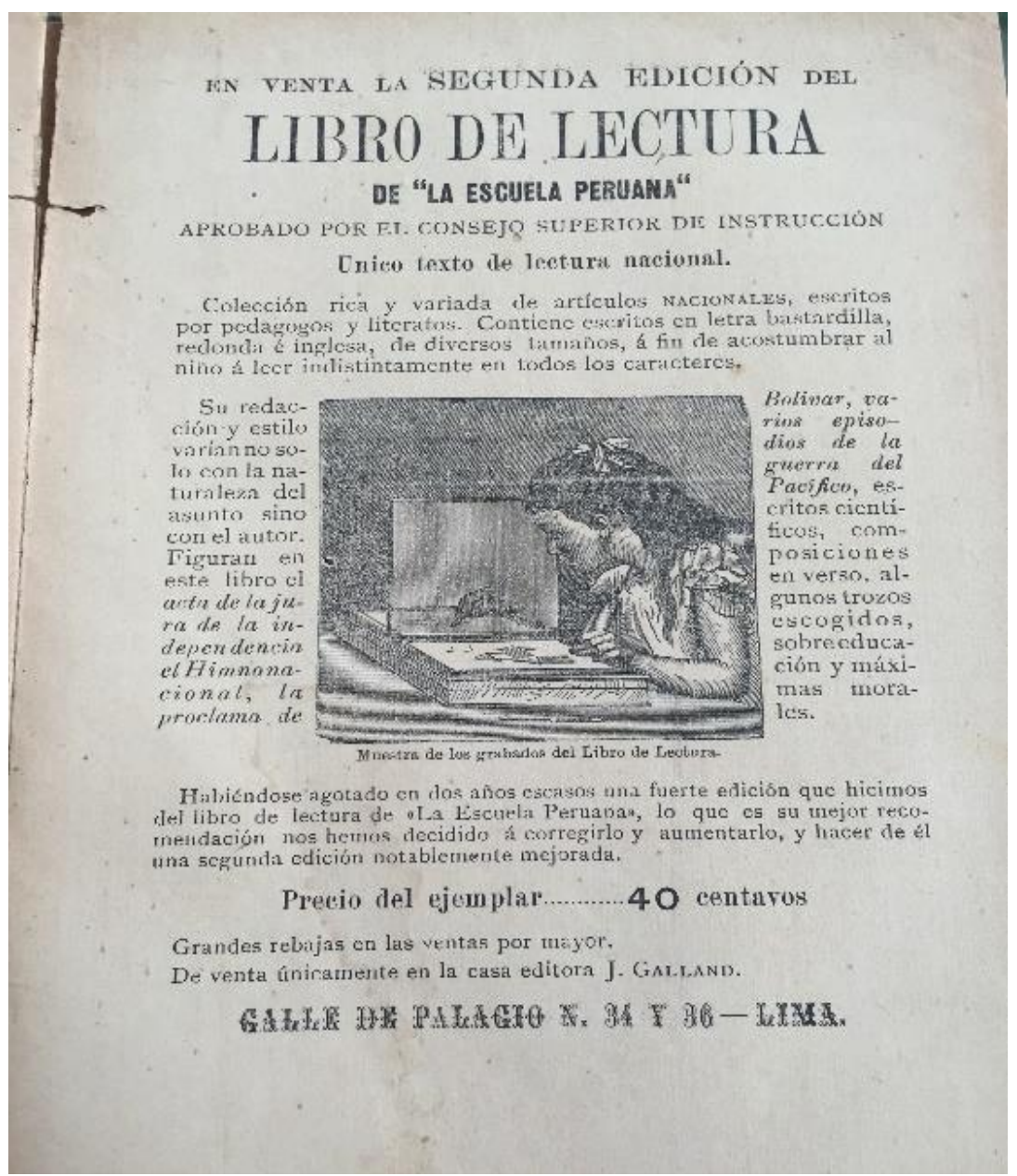

Source: "Libro de lectura," La Escuela Peruana, Lima June 1, 1895.

Many teachers and authors of school textbooks wrote them in order to provide students with a book customized for the needs of a specific class, school or colegio, but some authors also hoped their work would be used beyond the classroom. Máximo Vázquez, a jurist and teacher, hoped his civics textbook would be read by people beyond his classroom at Lima's Colegio de Guadalupe. He believed it could be useful to all citizens who had not attended formal juridical classes and particularly, if they held a position in 
government. ${ }^{365}$ Similarly, Leopoldo Arosemena wrote a book on Spanish grammar that could be used as an autodidactic text by people outside a formal classroom setting. According to the author, his readers only needed basic notions of Spanish grammar to teach themselves how to write correctly with the use of his Ortografía fundamental de la lengua castellana. ${ }^{366}$ Mariano Bolognesi published a book that summarized modern pedagogical methods in only twenty pages. He dedicated the book to mothers and suggested that the short manual would reach the far corners of the republic. ${ }^{367}$

Carlos Prince also started advertising textbook collections to attract customers to his Librería e Imprenta del Universo. Educational literature made up the largest category in the catalogue extract of his organ newspaper Boletín Bibliográfico. According to Prince, since he established his publishing house in 1882, he had published more than 300 small works (obritas) about distinct subjects including religion, education, legislation, the arts, sciences, industry and recreational literature. In addition to textbooks, Prince also sold various school materials including blank paper, notebooks, writing utensils, envelopes, pencils, chalk, chalkboards, cardboard alphabets, counting tables, calendars, agendas, story books with illustrations for children, and cases with school supplies. Teachers could also find collections of portraits of Inca rulers (colecciones de retratos de los incas del peru),

\footnotetext{
${ }^{365}$ See the foreword "Dos palabras" in Máximo Vázquez, Estudio de la constitución peruana para los cursantes del segundo grado de instrucción media y para los ciudadanos en general (Lima: Benito Gil, 1898), Fondo Antiguo, BNP, Lima, Perú.

${ }^{366}$ Leopoldo Arosemena Ortografía fundamental de la lengua castellana. Obra escrita expresamente para que cualquiera persona que tenga ligeras nociones de gramática, pueda por su misma aprender a escribir correctamente el idioma (Lima: Benito Gil, 1876), Fondo Antiguo, BNP, Lima, Perú.

${ }^{367}$ Mariano Bolognesi, Explicaciones provisionales sobre la enseñanza colectiva con el Nuevo método de lectura dedicado á las madres de familia por el Crel. M. Bolognesi (Lima: Impr. De la Escuela de Ingenieros, 1892), 1, Fondo Antiguo, BNP, Lima, Perú.
} 
among other items. ${ }^{368}$ The sale of materials that portrayed the pre-Hispanic past reflected a growing interest in teaching the history of Peru.

Booksellers and publishing houses also began to print political catechisms and works that explain the constitution under collections that targeted popular classes. ${ }^{369}$ Luis Bosio, deputy of the municipality of Callao, located right outside of Lima, published Catecismo Constitucional Peruano under the collection "Popular Education: Library of the People" (Educación Popular: Biblioteca del Pueblo). On the title page, he noted that it was a gift to the people (obsequio al pueblo) for the July 28, 1892 commemoration of Peruvian Independence. Eulogio Saldías, a navy official and professor at the Escuela Militar, published Enseñanza Cívica (Catecismo del Ciudadano) under the collection "Popular Instruction" (Instrucción Popular). As early as 1825, a political catechism appeared for its use in primary and secondary schools; however, by the end of the nineteenth century, civics texts could be found as part of bookstores' popular book collections. After the war with Chile, many elites sought to forge a collective Peruvian identity in order to foment patriotic sentiment and nationalism across broad sectors of the population, a task they believed would lead Peru to progress and military prowess. Table 7 shows the political catechisms published during the nineteenth century. Only one was published in the first half of the century. Five were published between 1850 and the conflict with Chile, while a total of eight were published after the war.

\footnotetext{
368 "Extracto del Catálogo de la Librería de la Imprenta del Universo, de Carlos Prince" in Boletín Bibliográfico, Lima, January 1, 1888- December 1, 1889.

${ }^{369}$ See Luis Bosio, Catecismo Constitucional Peruano (Callao: Imprenta del Muelle, 1892) and Eulogio S. Saldías, Enseñanza Cívica (Catecismo del Ciudadano) (Lima: Librería Francesa Científica y Casa Editora Galland, 1899).
} 
Table 7. Political Catechisms and Textbooks Published during the Nineteenth Century

\begin{tabular}{|c|c|c|c|}
\hline $\begin{array}{l}\text { Publishing } \\
\text { Date }\end{array}$ & Title & Author & City/Publisher \\
\hline 1825 & $\begin{array}{l}\text { Catecismo político para la } \\
\text { primera enseñanza de las } \\
\text { escuelas de la república del Perú }\end{array}$ & Antonio González & $\begin{array}{l}\text { Lima: Imprenta del } \\
\text { Gobierno }\end{array}$ \\
\hline 1855 & $\begin{array}{l}\text { Cartilla del pueblo sobre } \\
\text { principios democráticos }\end{array}$ & José Miguel Nájera & $\begin{array}{l}\text { Lima: Imprenta de } \\
\text { Eusebio Aranda }\end{array}$ \\
\hline 1859 & Catecismo patriótico & $\begin{array}{l}\text { Francisco de Paula } \\
\text { González Vigil }\end{array}$ & $\begin{array}{l}\text { Lima: Imprenta de } \\
\text { Esteban Dañino }\end{array}$ \\
\hline 1873 & $\begin{array}{l}\text { Derechos y deberes civiles y } \\
\text { políticos. Biblioteca de la } \\
\text { instrucción primaria superior }\end{array}$ & $\begin{array}{l}\text { Agustín de la Rosa } \\
\text { Toro }\end{array}$ & $\begin{array}{l}\text { Lima: Cortheoux y } \\
\text { Chateauneuf }\end{array}$ \\
\hline 1874 & $\begin{array}{l}\text { Catecismo civil de los deberes y } \\
\text { derechos del hombre y del } \\
\text { ciudadano }\end{array}$ & Aníbal Chiarolanza & $\begin{array}{l}\text { Lima: Imprenta del } \\
\text { Universo de Carlos } \\
\text { Prince }\end{array}$ \\
\hline 1875 & $\begin{array}{l}\text { Catecismo patriótico-politico } \\
\text { para eluso de las escuelas de } \\
\text { Instrucción Primaria de la } \\
\text { República }\end{array}$ & Jacinto Valderrama & $\begin{array}{l}\text { Trujillo: Imp de "El } \\
\text { Porvenir" }\end{array}$ \\
\hline 1885 & $\begin{array}{l}\text { Catecismo patriótico y los } \\
\text { mártires }\end{array}$ & José Luis Torres & $\begin{array}{l}\text { Lima: Imprenta del } \\
\text { Universo } \quad \text { (Carlos } \\
\text { Prince) }\end{array}$ \\
\hline 1889 & Catón Cívico & $\begin{array}{l}\text { Miguel Antonio de la } \\
\text { Lama }\end{array}$ & $\begin{array}{l}\text { Lima: Benito Gil } \\
\text { Imprenta y Librerías }\end{array}$ \\
\hline 1892 & $\begin{array}{lr}\text { Catecismo } & \text { Constitucional } \\
\text { Peruano Educación } & \text { Popular } \\
\text { Libro IV } & \\
\end{array}$ & Luis Bosio & $\begin{array}{l}\text { Callao: Imprenta del } \\
\text { Muelle Darsena y } \\
\text { Malecon }\end{array}$ \\
\hline 1896 & Manual del ciudadano elector & Antonio D. Reyna & Lima \\
\hline 1897 & $\begin{array}{l}\text { La Constitución del Perú con sus } \\
\text { reformas hasta } 1897 \text { explicada y } \\
\text { anotada para las escuelas y } \\
\text { colegios }\end{array}$ & $\begin{array}{l}\text { Miguel Antonio de la } \\
\text { Lama }\end{array}$ & Lima \\
\hline 1897 & $\begin{array}{l}\text { Manual del demócrata peruano y } \\
\text { Conducta del Hombre de bien }\end{array}$ & - & $\begin{array}{l}\text { Lima: Impr. De "El } \\
\text { País" }\end{array}$ \\
\hline 1899 & $\begin{array}{l}\text { Estudio de la Constitución } \\
\text { peruana para los cursantes del } \\
\text { segundo grado de instrucción } \\
\text { media y para los ciudadanos en } \\
\text { general }\end{array}$ & Máximo Vazquez & $\begin{array}{l}\text { Lima: Librería e } \\
\text { Imprenta Gil }\end{array}$ \\
\hline 1899 & $\begin{array}{l}\text { Ensenanaza Civica (Catecismo } \\
\text { del Ciudadano) }\end{array}$ & Eulogio Saldías & $\begin{array}{lrr}\text { Lima: E. } & \text { Rosay } \\
\text { Librería } & \text { Francesa } \\
\text { Científica y } & \text { Casa } \\
\text { Editora Galland } & \end{array}$ \\
\hline
\end{tabular}


Miguel De la Lama wrote two of the textbooks, Catón Cívico (1889) for primary schools and La Constitución del Perú (1897) in an attempt to adhere to new pedagogical methods as well as to directives from the most recent school code, which recommended the teaching of the Peruvian constitution in gradation. ${ }^{370}$ In Catón Cívico, De la Lama used the intuitive method to spark the interest of children with a series of images in the first pages. They included the Peruvian coat of arms, the flag and underneath, one child holding a sword, a second holding a book, and a third holding a balance. The images represented a "children's society" (sociedad infantil) and allegorized the abstract principles of the three branches of government and ideal organization of Peruvian society based on merit and ability. ${ }^{371}$ The book told the story of a group of children who loved certain fruits commonly eaten in Peru such as the palta or the larger South American avocado, peaches (melocotones), and oranges. The children came up with the idea of creating a garden where they could grow bounties of fruit. They discussed different ways of organizing the work including the option of leaving different occupations up to a random draw. Ultimately, they decided to go with elections where the older and more knowledgeable children would choose the most capable among them to fulfill different jobs. One of the children would make up the rules, another would be in charge of executing them, and a third would resolve conflicts.

\footnotetext{
${ }^{370}$ Miguel Antonio De la Lama, La Constitución del Perú con sus reformas hasta 1897 explicada y anotada para las escuelas y colegios, Segunda Edición (Lima: Imprenta Ledesma, 1897), 4-5.

${ }^{371}$ Miguel Antonio De la Lama, Catón Cívico para las escuelas de primer y segundo grado (Lima: Benito Gil, 1889),
} 
Emphasizing the duty of Peruvian citizens to the fatherland and the past heroic deeds of Peruvians became a common theme in civics books after the War of the Pacific. De la Lama defined the motherland (madre patria) as one Peruvian family or the sum of all Peruvian families and expressed that citizens owed more to the motherland than to their parents and "must serve it with ourselves and our property" (debemos servirla con nuestra persona y nuestros bienes). ${ }^{372} \mathrm{He}$ provided several examples of Peruvian martyrs, including Peruvian Independence heroes María Parado de Bellido and José Olaya, but focused on the more recent examples of Peruvians who gave up their lives during the conflict with Chile. He dedicated several more pages to the heroic deeds of Miguel Grau, Francisco Bolognesi, Juan Fanning, and others. This was also the case with José Luis Torres's Catecismo patriótico y los mártires, in which most of the pages listed the names and short biographies of the men who fought against Chile. ${ }^{373}$

Newly published history books complemented the themes in civics textbooks. During the 1890s at least eleven new textbooks focused on Peruvian history (see Table 8). The CSIP approved five of these books, in addition to nine other works that addressed classical, oriental, general, or modern history. ${ }^{374}$ Peruvian history textbooks organized the past around several epochs, sometimes broken into brief periods of reform. ${ }^{375}$ The first

\footnotetext{
${ }^{372}$ De la Lama, Catón Cívico, 18.

${ }^{373}$ José Luis Torres, 59- 203.

${ }^{374}$ See footnote 29.

${ }^{375}$ Mark Thurner dates this tendency to the work of Inca Garcilaso de la Vega, to which other writers like Antonio de Ulloa, José María Urrutia, and Sebastián Lorente copied and updated. Mark Thurner, "Una historia perana para el pueblo peruano. De la genealogía fundacional de Sebastián Lorente" in Sebastián Lorente and Mark Thurner, Escritos fundacionales de historia peruana (Lima: UNMSM, 2005), 15-76. In privileging Peruvian sources, Thurner argues that Lorente fell in line with the "patriotic epistemology" of eighteenth-century creole scholars who reacted against a wave of Enlightenment thought that discredited
} 
epoch concerned pre-Inca history or the time of "Curacas," a second period addressed the rise of Inca civilization, a third brief period focused on the Spanish Conquest, a fourth on the colonial period, and a fifth on the republican period-sometimes broken down into Independence and more contemporary history. ${ }^{376}$ When addressing the republican period, postwar writers like Pedro Manuel Rodríguez, took the opportunity to denounce Chilean crimes. ${ }^{377}$ One passage, which described the last efforts to resist the Chilean army by General Andrés Avelino Cáceres and his followers (the book was published under Caceres's presidency), noted that the Chileans, as usual, victimized prisoners and the wounded (los chilenos, como de costumbre victimaron á los heridos y prisioners). ${ }^{378}$

native sources and Spanish chroniclers. These intellectuals defended the work of Spanish chroniclers and creoles, arguing they had greater familiarity with native languages, customs, artifacts and monuments - the sources of historical truth. See Jorge Cañizares-Esguerra, How to Write the History of the New World (Stanford University Press, 2001), 204-265.

${ }^{376}$ Pedro Manuel Rodriguez, Nociones Generales de la Historia del Perú (Lima: J. Galland, 1890).

377 Pedro Manuel Rodríguez, Nociones de la Historia del Perú para las escuelas de Instrucción Primaria de la República (Lima: Galland, 1890), 126.

${ }^{378}$ Ibid, 128. 
Table 8. History Books Published during the Nineteenth Century

\begin{tabular}{|c|c|c|c|}
\hline Publishing Date & Title & Author & City/Publisher \\
\hline 1844 & Las 3 epocas del Peru, o, compendio de su historia & Jose Maria Cordova y Urrutia & Lima: Impr. Del autor \\
\hline 1853 & Historia del jeneral Salaverry & Manuel Bilbao & Lima: Impr. Del "Correo" \\
\hline 1856 & $\begin{array}{l}\text { compendio de la historia politica del Peru: escrito para el estudio de } \\
\text { los jovenes cursantes de humanidades }\end{array}$ & Manuel de Bilbao & Lima: Impr. Del Pueblo \\
\hline 1860 & Historia antigua del Peru & Sebastian Lorente & Lima: Poissy, Impr. Arbieu \\
\hline 1861 & Historia de la conquista del Peru & Sebastian Lorente & Lima: Poissy, Impr. Arbieu \\
\hline 1863 & Historia del Peru bajo la dinastia austriaca, 1542-1598 & Sebastian Lorente & Lima: Impr. A. Bouret \\
\hline 1864 & Compendio de la historia del Peru: epoca antigua & Jose Hipolito Herrera & Lima: Impr. De Aurelio Alfaro \\
\hline 1866 & Historia del Peru & Sebastian Lorente & Lima: Aubert \& Loiseau \\
\hline 1866 & $\begin{array}{l}\text { Historia del Peru: compendiada para el uso de los colegios y de las } \\
\text { personas ilustradas }\end{array}$ & Sebastian Lorente & Lima: Auber \& Loiseau \\
\hline 1869 & $\begin{array}{l}\text { Historia politica del Peru: dedicada a los alumnos de instruccion } \\
\text { primaria }\end{array}$ & Agustin de la Rosa Toro & Lima: Aubert y Cia \\
\hline 1871 & Historia del Peru bajo los Borbones: 1700-1821 & Sebastian Lorente & Lima: Librerias de Gil y Aubert \\
\hline 1873 & Curso de historia del Peru: para el colegio peruano & Enrique Benites & Lima: Impr. Del Estado \\
\hline 1876 & $\begin{array}{l}\text { Compendio de la historia antigua de Oriente para los colegios del } \\
\text { Peru }\end{array}$ & Sebastian Lorente & Lima: Benito Gil: Libr. Universal \\
\hline 1876 & Historia del Peru desde la proclamacion de la independencia & Sebastian Lorente & Lima: [s.n.], 1876 \\
\hline 1879 & Historia de la civilizacion peruana & Sebastian Lorente & Lima: Impr. Liberal \\
\hline 1886 & $\begin{array}{l}\text { Historia compendiada del Peru con algunas apreciaciones sobre los } \\
\text { viajes de Colon y sus hechos }\end{array}$ & Ricardo Cappa & $\begin{array}{l}\text { Lima: Carlos Prince, Impresor y } \\
\text { Librero, } 1886\end{array}$ \\
\hline 1887 & Historia del Peru & Agustin de la Rosa Toro & Lima: Benito Gil \\
\hline 1889 & $\begin{array}{l}\text { Apuntes de la historia del Peru: para el uso de las escuelas del 1o, } \\
20 \text {, y 3er. Grado }\end{array}$ & Aristarco Parodi Vivanco & Lima: Benito Gil \\
\hline 1889 & $\begin{array}{l}\text { compendio de la historia del Peru: para las escuelas de instruccion } \\
\text { primaria, conforme al programa oficial }\end{array}$ & Manuel Marcos Salazar & Lima: Benito Gil \\
\hline 1890 & Historia del Peru & Fanning & Lima: Benito Gil \\
\hline 1890 & $\begin{array}{l}\text { Nociones generales de la historia del Peru: para las escuelas de } \\
\text { InstrucciHistoria del Peruon Primaria de la Republica }\end{array}$ & Pedro Manuel Rodriguez & Lima: J. Galland \\
\hline 1891 & $\begin{array}{l}\text { Historia nacional: critica del diccionario historico-biografico del Peru } \\
\text { del senor General Mendiburu }\end{array}$ & Jose Toribio Polo & Lima: Impr. De El Comercio \\
\hline 1893 & $\begin{array}{l}\text { Compendio de historia del Peru: segun el metodo contemplativo y } \\
\text { conforme a los programs oficiales }\end{array}$ & Felix Nunez del Arco & Lima: Impr. Litogr. Y Libr. Gil \\
\hline 1894 & Lecciones de historia del Peru & Elvira Garcia y Garcia & Lima: Impr. De El Nacional \\
\hline 1897 & Compendio de la historia contemporanea para los colegios del Peru & Sebastian Lorente & Lima: Libr. E Impr. Gil \\
\hline 1899 & Compendio de la historia moderna: para los colegios del Peru & Sebastian Lorente & Lima: Edit. Moreno \\
\hline 1899 & Compendio de historia del Peru & Agustin de la Rosa Toro & $\begin{array}{l}\text { Lima: Libr. E Impr. Gil / Lima: } \\
\text { Libr. E Impr. Gil, } 1918\end{array}$ \\
\hline $1860 ?$ & $\begin{array}{l}\text { Historia de America y particulares del Peru dedicada a los alumnos } \\
\text { de los colegios de instruccion primaria del Peru }\end{array}$ & Agustin de la Rosa Toro & $\begin{array}{l}\text { Lima: s.n., 1860?/ Lima: Impr. J. } \\
\text { R. Montemayor, } 1866\end{array}$ \\
\hline $1885-1887$ & $\begin{array}{l}\text { v. Colon y los espanoles. Libro primero; Historia del Peru: los } \\
\text { exploradores; Los incas/Ricardo Cappa. Lima: Impr. Del Universo, } \\
1885 \text { v. 2; Historia del Peru: La conquista/ P. Ricardo Cappa. Lima: } \\
\text { Impr. Del Universo, 1886. v. 3; Historia del Peru: Las guerras } \\
\text { civiles y la anarquia/P. Ricardo Cappa. Lima: Impr. del Universo } \\
1887\end{array}$ & Ricardo Cappa & Lima: Impr. Del Universo \\
\hline $1892 / 1899$ & $\begin{array}{l}\text { Resumen de historia del Peru, arreglado en forma de texto para las } \\
\text { escuelas y los colegios de instruccion media/ } 1892 \text { Resumen de la } \\
\text { historia del Peru, arreglado en forma de texto para los colegios y } \\
\text { escuelas nacionales }\end{array}$ & Carlos Wiesse & $\begin{array}{l}\text { Lima [i.e. Lausana: E. Rosay / J. } \\
\text { Galland } 1892\end{array}$ \\
\hline
\end{tabular}


The publication of geography textbooks remained relatively steady after 1870 . The publications appeared in the context of renewed interest in Peruvian geography from the state and Peruvian intellectuals who hoped to attract European immigration, establish political boundaries, and more importantly, develop a free market based on the exploitation of Peru's natural resources. The Civilista Party made several efforts to institute scientific study of the geology and geography of Peru through the establishment of the School of Engineering and Mining (Escuela de Ingenieros Civiles y de Minas), and the School of Agriculture (Escuela Superior de Agricultura). They also funded Mariano Felipe Paz Soldán's, Diccionario Estadístico del Perú, and the expeditions and publications of Antonio Raimondi - today, considered the father of Peruvian geography. ${ }^{379}$ These efforts received new impetus after Cáceres ordered the foundation of the Sociedad Geográfica de Lima in 1888 and provided its members with government subsidies. ${ }^{380}$ By 1891 , the association published its first issue of Boletín de la Sociedad Geográfica de Lima. ${ }^{381}$ Renewed interest in geography showed in the content of school textbooks edited after the war and the creation of the Sociedad Geográfica. For instance, in 1897, Teresa González de Fanning augmented her Geografía Universal with a section on Peru. ${ }^{382}$ José Maticorena

\footnotetext{
${ }^{379}$ Mariano Felipe Paz Soldán, Diccionario Geográfico Estadístico del Perú (Lima: Imprenta del Estado, 1877) and Antonio Raimondi, El Perú: Historia de la geografía del Perú, Vol. 2-3 (Lima: Imprenta del Estado, 1876). Also see "Autorizando la publicación de los trabajos de don Antonio Raimondi sobre geografía, geología e historia,” January 28, 1869.

380 "Fundando la Sociedad Geográfica de Lima," February 22, 1888. The state granted the association 2,000 soles for its foundation and assigned 300 soles monthly, and later augmented the subsidy to 800 soles. See "Votando en el Presupuesto General los gastos de instalación de la Sociedad Geográfica," October 8, 1890 and "Aumentando la subvención asignada á la Sociedad Geográfica de Lima," November 22, 1892.

${ }^{381}$ Boletín de la Sociedad Geográfica de Lima (Lima: Imprenta Liberal de F. Masías y C.a, 1892).

382 Teresa González de Fanning, Geografía Universal (Lima: Imprenta y Librería de San Pedro, 1897); Máximo Vasquez, Geografía General (Lima: 1876). Vasquez reedited his textbook in 1902, see Curso abreviado de geografía.
} 
and Juan Verjel similarly included full sections on national geography. ${ }^{383}$ Earlier books such as Máximo Vázquez's Geografía General had left out sections on Peru. ${ }^{384}$ The CSIP approved a total of eleven geography textbooks during the 1890s and four of the books focused exclusively on Peruvian geography (see Table 9). ${ }^{385}$

The events of the War of the Pacific also made their way into geography books. Vergel's book opted for explaining the political limits before and after the war. ${ }^{386}$ One of the newly approved books, Rafael Paredes's Geografia del Perú, cited Bolivia as the southern border rather than Chile. After the war, in addition to annexing parts of the Peruvian littoral, Chile also annexed the Bolivian littoral leaving the latter landlocked, but Paredes refused to legitimize the new political limits in his work. ${ }^{387}$ Paredes included a prologue with a sharp indictment of Chile and a call to arms for Peruvians to restore the country's territorial integrity:

To you, the youth, I dedicate this modest work. To you who must put into practice the principles that have spread with much profusion during this century of progress and enlightenment. To you who, for your tender age, have been unarmed witnesses of the devastation, fire, and destruction perpetrated by the most barbarous and ferocious of enemies who have shocked the world. Finally, to you whose fathers and brothers, from the depths of the ocean and from the sands of Pisagua, Tacna and Arica conjure upon you the fulfillment of duty, that duty which imposes upon you the restoration of order, law, Justice and territorial integrity. ${ }^{388}$

\footnotetext{
383 José Francisco Maticorena, Compendio de Geografía Universal (Lima: Benito Gil, 1899) and Juan C. Verjel, Lecciones de Geografía (Lima: Librería Galland, 1889).

${ }^{384}$ Máximo Vasquez, Geografía General (Lima: 1876).

385 See footnote 29.

386 Verjel, Lecciones de Geografía, 42-3.

${ }^{387}$ See "Un texto oficial de geografía peruana" in Aurelio Bascuñán Montes, Miscelánea históricodiplomática (Imprenta Cervantes, 1908), 146-148.

${ }^{388}$ Ibid. Original text: “A vosotros, jóvenes, dedico este modesto trabajo; á vosotros que debeis poner en práctica los principios, con tanta profusion difundidos en este siglo de progreso y luces; á vosotros que,
} 


\section{Table 9. Geography Books Published during the Nineteenth Century}

\begin{tabular}{|c|c|c|c|c|}
\hline Year & Title & Author & City & Publishing house \\
\hline 1841 & $\begin{array}{l}\text { Curso elemental de geografia moderna que contine la } \\
\text { descripcion de las cinco partes del mundo }\end{array}$ & Francisco Gimeno & Lima & Imprenta de Instruccion primaria \\
\hline 1843 & $\begin{array}{l}\text { Nuevo curso completo de geografia universal: fisica, historica, } \\
\text { comercial, industrial y militar }\end{array}$ & $\begin{array}{l}\text { Antoine Sanchez de } \\
\text { Bustamante }\end{array}$ & $\begin{array}{l}\text { Madrid: } \\
\text { Lima }\end{array}$ & $\begin{array}{l}\text { Lib. De la Sra. Viuda de Calleja e } \\
\text { hijos: Casa de Calleja Ojea y Cia }\end{array}$ \\
\hline 1843 & $\begin{array}{l}\text { Geografia del Peru, Bolivia y Chile: para uso de los colegios y } \\
\text { escuelas de las tres republicas }\end{array}$ & $\begin{array}{l}\text { Antoine Sanchez de } \\
\text { Bustamante } \\
\end{array}$ & $\begin{array}{l}\text { Madrid: } \\
\text { Lima }\end{array}$ & $\begin{array}{l}\text { Lib. De la Sra. Viuda de Calleja e } \\
\text { hijos: Casa de Calleja Ojea y Cia }\end{array}$ \\
\hline 1859 & Compendio de geografia del Peru & Pedro Dominquez & Lima & $\begin{array}{l}\text { Impr. De El Catolico por Jose D. } \\
\text { Huerta }\end{array}$ \\
\hline 1865 & $\begin{array}{l}\text { Primeras lecciones de geografia astronomica: para el Colegio } \\
\text { de Guadalupe }\end{array}$ & Sebastian Lorente & Lima & Libr. De Benito Gil \\
\hline 1866 & $\begin{array}{l}\text { Geografia comparada, o, Estudio comparativo de la tierra, } \\
\text { considerada bajo el punto de vista fisico, fisiologico y politico }\end{array}$ & Agustin de la Rosa Toro & Lima & Impr. Dirigida por J. R. Montemayor \\
\hline 1866 & Lecciones de geografia historica & Sebastian Lorente & Lima & Impr. Y Litogr. De E. Prugue \\
\hline 1869 & $\begin{array}{l}\text { Curso de geografia moderna destinado a la ensenanza de los } \\
\text { alumnos del Colegio Peruano }\end{array}$ & Enrique Benites & Lima & Lima: Impr. J. R. Sanchez \\
\hline 1870 & $\begin{array}{l}\text { Curso de geografia general descriptiva yparticular de America } \\
\text { destinado a la ensenanza de los alumnos del Colegio Peruano }\end{array}$ & Enrique Benites & Lima & Tip. De "El Nacional" \\
\hline 1871 & curso de geografia universal para los colegios del Peru & Antonio Eliseo Larranaga & Lima & A. Mily de la Roca \\
\hline 1873 & Compendio de la geografia astronomica & Jose Manuel Reyna & Lima & Impr. De J. F. Solis \\
\hline $\begin{array}{r}1874- \\
1913\end{array}$ & El Peru: historia de la geografia del Peru & Antonio Raimondi & Lima & Impr. Del Estado \\
\hline 1874 & Geografia general de America: para la clase quinta & Leopoldo Contzen & Lima & Empresa Tipografica \\
\hline 1875 & $\begin{array}{l}\text { Geografia general de Europa: para los colegios de instruccion } \\
\text { media }\end{array}$ & Leopoldo Contzen & Lima & Empresa Tipografica \\
\hline $\begin{array}{r}1876 \\
1889 \\
\end{array}$ & Geografia General & Maximo Vazquez & Lima & N/A \\
\hline 1876 & Tratado de Geografia & Leopoldo Contzen & Lima & N/A \\
\hline 1876 & $\begin{array}{l}\text { Nociones generales de geografia para las clases preparatoria } \\
\text { y sexta del Instituto de Lima }\end{array}$ & Manuel Maria Forero & Lima & Emp. Tip. \\
\hline 1876 & Compendio de Geografia antigua y de cronologia & Juan B. Goytizolo & Lima & Courheoux \\
\hline 1878 & Curso de geografia historica del Peru & Enrique Benites & Lima & Impr. Del Estado \\
\hline 1880 & $\begin{array}{l}\text { Geografia de los estados unidos Peru-Bolivianos, } 0 \text {, sea } \\
\text { Republica federal de los incas, con varios documentos de } \\
\text { actualidad }\end{array}$ & Simon Martinez Izquierdo & Lima & Impr. Del Universo, de Prince y Buxo \\
\hline 1883 & Curso de geografia universal & Juan C. Lopez & Lima & Tip. De La Sociedad \\
\hline
\end{tabular}

por vuestra tierna edad habeis sido testigos inermes de la devastación, del incendio y de la tala perpetrados por el más bárbaro y feroz de los enemigos, que han pasmado de espanto al mundo; á vosotros, en fin, cuyos padres y hermanos, desde el fondo del Océano y desde los arenales de Pisagua, Tacna y Arica, os conjuran al cumplimiento del deber, de ese deber que os impone el restablecimiento del orden, del derecho, de la justicia y de la integridad territorial." 


\begin{tabular}{|c|c|c|c|c|}
\hline 1884 & $\begin{array}{l}\text { Elementos de geografia astronomica, fisica y } \\
\text { politica//Elementos de geografia astronomica, fisica y politica } \\
\text { Lima: E. Moreno Editor, } 1898\end{array}$ & Enrique Benites & Lima & Benito Gil \\
\hline 1885 & $\begin{array}{l}\text { Compendio de geografia Moderna Universal para las } \\
\text { Escuelas de Instruccion Primaria de Tercer Grado }\end{array}$ & Enrique Benites & Lima & $\begin{array}{l}\text { Benito Gil, Libreria Universal Calle } \\
\text { de Lampa, (Banco del Herrador) N. } \\
\text { o } 113 \text { Sucursal Calle de Carabaya, } \\
\text { (bodegones) } 42\end{array}$ \\
\hline 1885 & $\begin{array}{l}\text { Curso de geografia del Peru para la instruccion media: } \\
\text { arreglado conforme al programa oficial }\end{array}$ & Enrique Benites & Lima & Benito Gil \\
\hline 1886 & Lecciones de geografia para las escuelas comunes & Mariano Felipe Paz Soldan & BA & F. Lajouane \\
\hline 1888 & $\begin{array}{l}\text { Primeras lecciones de geografia para las escuelas de primer } \\
\text { grado }\end{array}$ & Juan E. Diaz & Lima & B. Gil \\
\hline 1889 & Lecciones intuitivas de Geografia sobre el mapamundi & Juan C. Verjel & Lima & Libreria Francesa Cientifica Galland \\
\hline 1889 & Lecciones de geografia del Peru & Carlos Wiesse & Lima & J. Galland \\
\hline 1889 & Primer libro de Geografia & Carlos Wiesse & Lima & J. Galland \\
\hline 1890 & Lecciones de geografia general y particular del Peru & Carlos Wiesse & Lima & J. Galland \\
\hline 1892 & $\begin{array}{l}\text { Metodo Grafico Geografia del Peru para la Ensenanza } \\
\text { Primaria }\end{array}$ & Federico Villareal & Lima & Libreria Francesa Cientifica \\
\hline 1892 & Geografia del Peru & Federico Villareal & Lima & Libreria Francesa Cientifica \\
\hline 1896 & $\begin{array}{l}\text { compendio de geografia universal, puesta al nivel de los } \\
\text { conocimientos geograficos mas recientes }\end{array}$ & M.O. Suarez & Lima & Libr. Francesa Cientifica J. Galland \\
\hline 1897 & Lecciones de Geografia Universal & Teresa G. de Fanning & Lima & Imprenta y Libreria de San Pedro \\
\hline 1897 & Geografia comercial de la America del Sur & Carlos Cisneros & Lima & Impr. Y Libr. De San Pedro \\
\hline 1898 & $\begin{array}{l}\text { Geografia botanica: apuntes extractados para los alumnos de } \\
\text { la Facultad de Ciencias }\end{array}$ & Alfredo Leon & Lima & Impr. Liberal \\
\hline 1899 & Compendio de Geografia Universal & Jose Francisco Maticorena & Lima & $\begin{array}{l}\text { Benito Gil--Imprenta y Librerias, } \\
\text { Canco del Herrador 113- Bodegones } \\
42\end{array}$ \\
\hline 1900 & Diccionario geografico escolar del Peru & Aristarco Parodi Vivanco & Lima & El Autor \\
\hline 1900 & $\begin{array}{l}\text { Lecciones de topografia dictadas en la escuela de ingenieros } \\
\text { recopilacion hecha por los alumnos }\end{array}$ & varios & Lima & $\mathrm{N} / \mathrm{A}$ \\
\hline 1902 & $\begin{array}{l}\text { Curso abreviado de geografia general y del Peru: para el } \\
\text { primer y segundo grado de instruccion primaria// Curso } \\
\text { abreviado del Peru, para el segundo grado de la instruccion } \\
\text { primaria: Texto autorizado por el Consejo Superior de } \\
\text { Instruccion Lima: [s.n.] } 1897\end{array}$ & Maximo Vazquez & Lima & Libr. E Imp. Gil \\
\hline
\end{tabular}

The activities of bookstores and printing houses after the War of the Pacific show a dramatic expansion in the Peruvian textbook industry. National education became the subject of intense criticism from Peruvians who believed its deficiencies were to blame for the loss to Chile and for Peru's economic ills. Thus, reestablished businesses and new bookstores serviced a growing demand for Peruvian school textbooks with national content. Teachers and writers intensified efforts to produce and circulate a broad range of textbooks with abridged and practical information hoping to improve the skills of workingclass Peruvians and promote national industry. They also published a series of textbooks 
about Peru's geography, history and constitution, hoping to spread nationalism among the populace. Booksellers advertised school textbooks of all levels to teachers, parents and students, adding to the efforts of a weakened state that had been unable to promote the circulation of new literature with updated pedagogical methods and educational content.

\section{Popular Libraries}

The expansion of Lima's publishing industry also meant that bookstores could meet a growing demand for a broad range of popular literature that extended beyond school textbooks to encompass "how to" and "self-help" manuals as well as recreational and religious books. This market flourished as Lima's literacy rates expanded particularly by the turn of the century, reaching 59 percent for people over six years of age by 1876 and 80 percent by $1908 .{ }^{389}$ To meet the demand, booksellers continued to copy or edit translations of foreign - especially European works, but they also looked to find native authors who could represent imagined national traditions-sometimes expressed as "peruano" and other times as "criollo." 390 Booksellers formed "popular libraries" or collections of popular books to reach a market of readers within the working classes whom

\footnotetext{
389 Toward the end of the colonial period, only about 20 percent or about 1,000 school-age Limeños could read. This figure remained the same toward 1845. For literacy rates in the late colonial period, see Cristóbal Aljovín de Losada, Caudillos y constituciones (Perú, 1821-1845) (Lima: Instituto Riva-Agüero, Fondo de Cultura Económica, 2000). Aljovín's work as well as figures for 1845 and 1860 are mentioned in Jose Ragas, "Leer, escribir, votar. Literacidad y cultura política en el Perú (1810-1900)," Historica 31 (2007): 115. For 1876 and 1908, see comparisons of both years in Censo de la provincia de Lima (Lima: Impr. De "La Opinión Nacional, 1915), 102.

${ }^{390}$ During the nineteenth century, the term criollo as used in Peru, came to represent cultural practices, attitudes and objects from Lima and the Peruvian coast, in addition to its colonial connotation describing a person born in the Americas of Spanish descent. Despite the geographic specificity of the latter connotation, intellectuals adopted the term as a synonym for national or Peruvian traditions. See Luis Gómez Acuña, "Lo criollo en el Perú republicano: breve aproximación a un término elusivo," Histórica XXXI.2 (2007): 115-166.
} 
intellectuals also saw as the source of an authentic national culture. Thus, Lima's popular reading culture formed in relation to limeños' reading predilections but also in relation to booksellers' and writers' notions of what types of books should constitute popular libraries.

Instructional manuals and educational literature constituted an important aspect of popular libraries. Benito Gil published catalogues of his entire collections, advertising a wide range of manuals and didactic books that could be found in various sections including "Manuals," "Library for the Youth" (Biblioteca de la Juventud), "Teaching Section" (Sección de Enseñanza), "Library of Wonders" (Biblioteca de las Maravillas), and "Hispanic-American Library" (Biblioteca Hispano-Americana). ${ }^{391}$ The last section contained manuals about a variety of trades and professions and was advertised as the "most complete collection of manuals published to date" (See Table 10). ${ }^{392}$ The manuals instructed on subjects about agriculture, law, the fabrication of foods, wines and liqueurs, bricklaying, commercial arithmetic, architecture, astronomy, the preparation of varnish and lacquer, law enforcement, and many others. The majority of the books in the catalogue had physical descriptions indicating the number of volumes and the sizes, which corresponded to $4^{\circ}$ (cuarto), $8^{\circ}$ (octavo), $12^{\circ}$ (dozavo) or $16^{\circ}$ (dieciseisavo), etc. The sizes referred to the number of sheets in the book created through folding a single "folio" or paper. The octavo, for instance, had folios folded in half twice, creating 8 sheets or 16 pages. The larger the number, the smaller the book. The table below shows all the titles listed under this collection categorized by their subject.

\footnotetext{
${ }^{391}$ Catálogo General de las Librerías de Benito Gil (Lima, 1886), Fondo Antiguo, BNP, Lima, Perú. ${ }^{392} \mathrm{Ibid}, 31$.
} 
Table 10. Manuals sold at the Bookstore of Benito Gil in 1886

\begin{tabular}{|c|c|c|c|}
\hline Agricultural & $\begin{array}{l}\text { Agricultura y Ganadería } \\
\text { Agrimensor } \\
\text { Agrología } \\
\text { Cultivo de algodón } \\
\text { Cultivo de añil y del nopal } \\
\text { Cultivo del café, cacao, } \\
\text { vainilla y tabaco } \\
\text { Cultivo de caña de azúcar } \\
\text { Lechería }\end{array}$ & Skilled Labor & $\begin{array}{l}\text { Albañilería } \\
\text { Barnices y preparación de charoles } \\
\text { Carpintero de muebles y edificios } \\
\text { Construcción de caminos de hierro } \\
\text { Fotografía } \\
\text { Del jardinero y arbolista } \\
\text { Laborero de minas } \\
\text { tornero } \\
\text { Telegrafía eléctrica } \\
\text { Relojero } \\
\text { Sastre } \\
\text { Hojalatero y lamparista } \\
\text { Curtidor } \\
\text { Flebotomianos, sangradores y } \\
\text { dentistas }\end{array}$ \\
\hline Industrial & $\begin{array}{l}\text { Aceites y jabones } \\
\text { Cohetero y polvorista } \\
\text { Fabricante de velas de sebo y } \\
\text { del Cerero } \\
\text { Del florista artificial }\end{array}$ & $\begin{array}{l}\text { Law } \\
\& \\
\text { Professional }\end{array}$ & $\begin{array}{l}\text { Abogados } \\
\text { Arquitectura } \\
\text { Derecho público eclesiástico }\end{array}$ \\
\hline Recreational & $\begin{array}{l}\text { Esgrima } \\
\text { Juegos }\end{array}$ & $\begin{array}{l}\text { Administrative \& } \\
\text { Commercial }\end{array}$ & $\begin{array}{l}\text { Administración } \\
\text { Aritmética Comercial } \\
\text { Capitalista }\end{array}$ \\
\hline Sciences & $\begin{array}{l}\text { Astronomía } \\
\text { Química divertida } \\
\text { Economía política }\end{array}$ & Food/Drink & $\begin{array}{l}\text { Confitero } \\
\text { Destilador, licorista y perfumista } \\
\text { De cervecero y fabricante de bebidas } \\
\text { gaseosas y fermentadas }\end{array}$ \\
\hline Military & $\begin{array}{l}\text { Cabo y sargento } \\
\text { Táctica de las tres Armas } \\
\text { aisladas y reunidas }\end{array}$ & Other & $\begin{array}{l}\text { Efemérides y anualidades } \\
\text { Mágica Blanca } \\
\text { Moral Cristiana } \\
\text { Mitología } \\
\text { Hidroterapia } \\
\text { Música }\end{array}$ \\
\hline
\end{tabular}

Source: Catálogo General de las Librerías de Benito Gil (Lima, 1886).

Prince's Boletín advertised manuals with practical knowledge for even the most "rebellious minds," targeting a broader readership outside formal schooling. ${ }^{393}$ This was the case with Guía práctica para el escritorio del comerciante or the Manual del Jabonero ó sea la fabricación del Jabon al alcance de todos advertised in the January 1, 1888 issue of the publication. The reviewer of the last book stated that this work was another "small work" (obrita) of general utility edited by the publishing house. The writer emphasized

${ }^{393}$ Boletín Bibliográfico (Lima), January 1, 1888. 
that "in publishing this small treatise we have the conviction of having made a service to the public because in the future, the elaboration of soap will not be a secret, as most manufacturers would prefer. ${ }^{394}$ The writer speculated that some readers would use the manual out of financial need, implying soap was expensive and in short supply. He stressed that the manual would help make soap an abundant and cheap product rather than a scarce and expensive one. Many of the manuals were advertised using diminutives such as "obrita," "tratadito," "librito." While the use of the diminutive in Latin America was and continues to be widespread, its use in the newspaper often referred to books that were published in Prince's own publishing house. The diminutive conveyed a sense of modesty, which was common for Spanish and Latin American nineteenth-century authors. In Prince's periodical, however, its use may have also signaled the accessible prices and modest construction of books to incentivize people of diverse backgrounds to visit the bookstore and purchase the book.

Two months after the publication of the first issue of Boletín Bibliográfico, Prince alluded to the utility and affordability of the books that made up his Biblioteca Popular. ${ }^{395}$

Mostly because of the modest prices of these publications, the public favors us more every day, giving our works a welcomed reception which greatly honors us. Therefore, we take every measure to provide good service and careful impression, choosing at the same time treatises that are more adaptable to the different tastes of the consumer. ${ }^{396}$

\footnotetext{
${ }^{394}$ Ibid. Original text: “Al publicar este pequeño tratadito tenemos la convicción de haber hecho un beneficio al público, porque en lo sucesivo la elaboración del jabón dejara de ser un secreto, como pretenden la mayoría de los fabricantes."

395 “La Biblioteca Popular,” Boletín Bibliográfico, March 1, 1888.

396 Ibid, Original text: "Los módicos precios de dichas publicaciones, hacen en gran parte, que el público nos favorezca mas cada día, dando á nuestras obras una acojida predilección que nos honra sobremanera. Por lo que, también nosotros, no omitimos medio alguno en su buen servicio y esmerada impresión, escogiendo al propio tiempo, los tratados que mas se adaptan á los diferentes gustos del consumidor."
} 
He noted that a series of small works published by his Imprenta del Universo and encompassing all branches and subjects in the various arts and sciences and literature constituted the collection. Instructional manuals made up the printing house's preferred line of books because they "enabled the learning of the people. ${ }^{397}$ Still, Prince assured the collection was also shaped by the predilections of customers. The number of titles listed under Prince's popular library was only second to the number of books listed under the categories of school textbooks and religion. Prince promoted the books as cheap and accessible to all readers. Moreover, he advertised that he selected the works in the collection for their recreational and utilitarian value to the people. Many of the books were available in octavo format, which sold at lower prices. ${ }^{398}$

In bookstore catalogues, the category of popular library also encompassed an assortment of books that reflected popular interest in diverse subjects. While the national government had not established the bricks-and-mortar popular libraries (bibliotecas populares) mentioned in the 1876 Reglamento and other laws, booksellers created their own popular book collections. To be sure, their collections included many volumes in the category of recreational literature, rather than the utilitarian and practical works that political elites hoped would fill bricks-and-mortar popular libraries. Moreover, they also continued to show Limeños's strong interest in European literature. Benito Gil’s category of "Bibliotecas Populares Llamadas de Ferrocarril," for instance, consisted of works

\footnotetext{
${ }^{397}$ Ibid, Original text: “Son particularmente los Manuales de nuestra preferente atención, procurando el aprendizaje del pueblo." Emphasis in original text.

398 Original text: "Esta interesante colección de obritas escogida de suma utilidad y entretenimiento para el pueblo, consta de un crecido número de volúmenes en $8^{\circ}$, que se venden a precios tan reducidos, que están al alcance de todos."
} 
written by nineteenth-century, European (especially Spanish and French) novelists, poets and playwrights including Julio Verne, Laboulaye, Lamartine, Llanos y Alcaraz, Souvestre, Pelletan, and Galdós. ${ }^{399}$ Still, when compared to earlier advertisements, bookstore advertisements and catalogues of the second half of the nineteenth century show an overall diversification of Lima's readerships and a growing interest in national literature beyond textbooks.

Book merchants and printing houses published several books that compiled the lyrics of popular songs and tunes, marketing many of them as "national" or "Peruvian" music. Imprenta Bolognesi, for instance, advertised Colección de Yaravíes Peruanos "taken from the work of Melgar, Castillo, J. L. Mera, El Chico Terencio, Elera, and from various manuscripts," Colección de canciones populares, and Nueva Colección de Canciones Peruanas. ${ }^{400}$ The latter had at least two editions and was part of a series of volumes compiled by Neptalí García — a local writer also known by his pseudonym Blas Cartujo and a member of one of Lima's literary clubs. ${ }^{401}$ Book trader Pedro D. Crovetto advertised Canciones populares and Yaravies peruanos as part of his collection of books for schools and for the instruction and recreation of "the people" (el pueblo). ${ }^{402}$ Juan

${ }^{399}$ Catálogo General de las Librerias de Benito Gil, 63-69.

${ }^{400}$ La Revista Social (Lima), June 27, 1885.

401 “Canciones Peruanas,” La Revista Social (Lima), July 4, 1885. Neptalí García appears as member of Lima's Círculo Literario in "Circulo Literario" in El Comercio (Lima), November 8, 1887, 3 and Boletín de la Academia Peruana correspondiente de la Real Española de la Lengua (Lima: Imprenta del Estado, 1918), 169.

402 "Pedro D. Crovetto" in La Revista Social(Lima), August 8, 1885. Original text of the advertisement: "Libros para colegios y para instrucción y recreo del pueblo. Entre estos figuran: Canciones Populares, Yaravíes Peruanos, El Código del Amor, Las Muchachas Casaderas, Lenguaje de las Flores, Frutas, Abanico y Pañuelo, Cartas Amorosas, El Libro de Oro, El Arte de Buscar Marido, Libros de Cuentos para niños, Novenas de todas clases. Cuadernos, y un variado surtido de libros de lectura amena y religiosa." 
Galland edited and sold the Nuevo Cancionero Popular: Colección de canciones, tristes, yaravies, etc. No $5 .{ }^{403}$ The songs belonged to various genres of music like the huayno, triste, or harawi, later Hispanicized as "yaravi," which fused Andean musical instruments such as the quena, antara and pututo with Spanish poetic tunes. ${ }^{404}$ Toward the end of the century, these compilations also included Peruvian versions of European valses and polkas. ${ }^{405}$

In his March 1888 issue of Boletín Bibliográfico, Carlos Prince discussed the demand for books that compiled popular songs, but noted many of the volumes that had appeared were not faithful to the original yaraví or huayñu because they mixed them with habaneras, danzas and other genres. For Prince, nations needed to stand out with original cultural expressions. He argued the yaraví and huayñu were distinctive to Peru and dated to a "time immemorial of the Inca epoch." 406 In making this argument, he denied the European component of the genres. According to Prince, he was motivated to provide a real service to Peruvian letters when he edited D. Celso Víctor Torres's Yaravíes y Hayñu with unpublished content faithful to the "ancient Peruvian poetry." The volume was available in octavo and consisted of 150 pages. In an advertisement for another edited volume, he described the yaraví and the triste as "exclusive to the pure national Indian

\footnotetext{
${ }^{403}$ Cancionero popular (Lima: Librería Francesa y Casa Editora J. Galland 34 y 36 Calle de Palacio, 1897).

404 “Nueva colección de Yaravíes y Huayñus peruanos” in Boletín Bibliográfico, March 1, 1888.

${ }^{405}$ Luis Gómez Acuña, “Lo criollo en el Perú republicano: breve aproximación a un término elusivo,” 131.

406 "Nuevos libros editados por nuestra Casa-Librería," in Boletín Bibliográfico, March 1, 1888. Original text: "Las naciones se distinguen en algo de sí propio. El Haraví o Yarrví el Huayñus son peculiares y datan desde tiempo inmemorial de la época incásica."
} 
race" (la pura raza nacional Indiana) and its suffering and misfortunes. ${ }^{407}$ These volumes constituted a series of little books (libritos) of popular tunes published by Prince's business. The collection also included Repertorio de Himnos y Canciones Populares de las Repúblicas Sud-americanas, Ramillete del Bello Sexo, and Ramillete de las Limeñas. Additionally, the editor advertised Marcos A. Gerona's Recopilación de Yaravíes, Manojito de poesías lýricas, and La Mistura. The last two compiled valses, habaneras, jotas, malagueñas, romanzas, and other popular tunes (tonadas).$^{408}$

Despite the publication of compilations of what writers and editors considered national popular songs, one letter writer noted that they had long lacked written scores. The writer regretted that many Peruvian poets did not have the technical ability to write the music, which was "somewhat lovely" (más o menos bonito) ${ }^{409}$ Many musicians who did possess those abilities preferred to dedicate their time to the "Italian romantic genre," leaving no one to write music that was "essentially creole and cheerful" and could "translate the popular sentiment." ${ }^{310}$ Unlike Prince's more narrow definition of authentic national music, this writer believed it encompassed broad genres as long as the authors of individual works were Peruvian. Thus, he celebrated that Francisco Brenner was writing the music for the lyrics of an "essentially national" zarzuela —a traditional Spanish musical play—a few months before the 1897 commemoration of Peruvian Independence:

\footnotetext{
407 “Colección de Yaravíes y Tristes Nacionales," Boletín Bibliográfico, August 1, 1888.

${ }^{408}$ Ibid.

409 “Música Nacional,” El Comercio, May 5, 1897.

${ }^{410}$ Ibid. Original text: "No habría, en realidad, quien escribiera una música esencialmente criolla y alegre que tradujera el sentimiento popular."
} 
Thus, Mr. Brenner, as citizen and a patriot, remains committed to contribute his part to the celebration of the patriotic festivities by finishing a zarzuela that will be eminently Peruvian, both because of its narrative and because its music translates the national sentiment. ${ }^{411}$

The writer saw this as a step forward in the production of national music, akin to erecting public buildings, creating artistic works, and founding new philanthropic societies.

Peruvian cookbooks constituted another component of the bourgeoning book industry that extolled national culture. In 1883, El Comercio advertised El Cocinero Práctico, a publication augmented with stews (potajes) "a la criolla." 412 Nuevo Manual de la Cocina Peruana por un Limeño Mazamorrero, edited by Galland's publishing house, included recipes for "culinary preparations, cakes, marmalades, candies, and other items considered essentially creole" (see Figure 2). ${ }^{413}$ It contained 320 recipes and customers could obtain it for 60 cents. ${ }^{414}$ The Nuevo Manual de la Cocina Peruana (1895), also edited by Galland's publishing house, compiled recipes from various regions of Peru. ${ }^{415}$ La Mesa Peruana appeared in 1867 and was reedited in 1897 and 1924. The author advertised the book as edited "according to national customs and uses." ${ }^{416}$ In addition to recipes, the book

\footnotetext{
${ }^{411}$ Ibid. Original text: “Queda, pues, el señor Brenner como ciudadano y como patriota comprometido á contribuir, por su parte, á la celebración de las fiestas patrias terminando la zarzuela que será eminentemente peruana, tanto porque el argumento lo es, cuanto porque la música traduce el sentimiento nacional." 
included content on proper housekeeping and table etiquette, making it ideal for the education of young girls. Similarly, educator Teresa González de Fanning included a collection of recipes in her textbook on domestic economy. ${ }^{417}$ The collection included recipes of dishes and beverages now considered a hallmark of Peruvian cuisine like the humita, mazamorra morada, and others. In addition to aiding women in the home, cookbooks also offered a tool for women to develop a socially acceptable occupation in a growing industry of food preparation, sweets, or pastries for cafés, eating houses, inns bakeries, or candy shops. ${ }^{418}$

\footnotetext{
${ }^{417}$ Teresa González de Fanning, Lecciones de Economía Doméstica (Lima: Imprenta y Librería de San Pedro, 1893), 55-66.

${ }^{418}$ In 1876, a commercial guide listed five fondas or eating houses in Lima. By 1887 the number grew to at least 100 in Lima and neighboring Callao. See Almanaque del Comercio de Lima (Lima: Imprenta del Estado, 1876), 176-7 and Guía de Domicilio é Industrial de Lima Y Comercial del Callao para el año 1887 (Lima: Imp. Masías, 1887), 160-1. Many of these establishments advertised dishes "a la criolla." See for example "Fonda" in El Comercio (Lima), October 30, 1896 and "Restaurant de la "Exposición," El Comercio (Lima), July 7, 1894.
} 
Figure 2. Nuevo Manual de la Cocina Peruana por un Limeño Mazamorrero

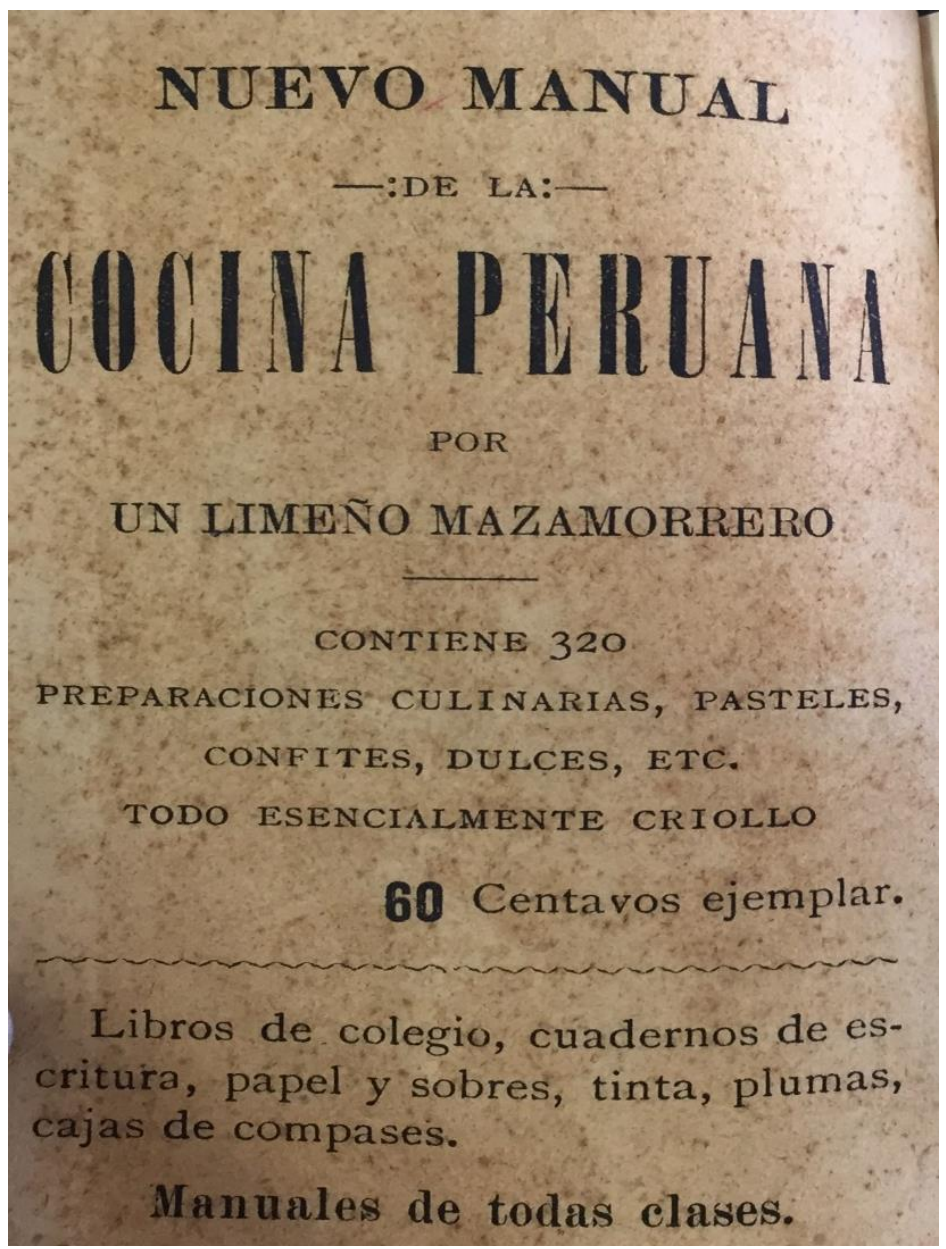

Conclusion

Lima underwent a profound cultural transformation during the last decades of the nineteenth century. The proliferation of dozens of bookstores and publishing houses meant that more people had access to cheaper books. The subject of books also changed. Prior to the War of the Pacific, Lima's bookstores often advertised their European collections. After the war, elite efforts to promote Peruvian nationalism led to the increased publication of textbooks on the Peruvian constitution and civics. Educators also sought to incorporate 
Peruvian motifs into reading books and history and geography texts. While they cited the latest pedagogical methods, they also believed moving toward using national textbooks would help forge Peruvian nationalism. Popular libraries with new books about all-thingsnational emerged vis-à-vis Lima's textbook industry, which similarly began to reflect national content by national or immigrant authors. The literature reflected efforts of writers and editors to capture what they imagined as authentic national culture, an endeavor they hoped would also form and stimulate "public spirit."419

419 “Música Nacional," El Comercio, May 5, 1897. 


\section{CHAPTER IV}

\section{Legitimizing Text and Method in Lima’s Public Sphere of Pedagogical Society}

When San Marcos professor Enrique Guzmán y Valle founded the pedagogical periodical La Instrucción in November of 1889, he believed it would help channel previously disjointed efforts to organize, uniform and modernize education in Peru. "Thus far," he noted in the first issue, "everything has been done through individual efforts." 420 He believed, however, that a "pedagogical movement" was brewing, citing the foundation of El Faro-a contemporary Peruvian pedagogical newspaper-as well as educational reforms, and significant changes occurring in schools throughout the country. ${ }^{421} \mathrm{He}$ noted that all elements of schooling, including the "physical condition of school buildings, classroom furniture and supplies, the distribution of time, recreational activities and schoolwork for students as well as methods used to meet educational goals with more efficiency" had become the subject of study, specialized regulation, and innovation. ${ }^{422}$ This chapter examines the late nineteenth-century pedagogical movement described by Guzmán y Valle or rather, the emergence of a "public sphere" of pedagogical society through which

\footnotetext{
420 "Nuestro Proposito,” La Instrucción (Lima), November 10, 1889. Original text: “...todo se ha hecho hasta la fecha por esfuerzos individuales."

421 “Noticias Varias,” La Instrucción, November 10, 1889. Original text: “"El Faro'-Anúnciase que próximamente verá la luz pública un periódico destinado á difundir la enseñanza popular, bajo la dirección del doctor Juan Ramos y Palacios. Deseamos que se cumpla el propósito; pues ya es tiempo de que se manifieste nuestro movimiento pedagógico." Also see "El Local de la Escuela," La Instrucción, December 10, 1889.

422 “El Local de la Escuela," La Instrucción, December 10, 1889. Original text: "El actual movimiento pedagógico se distingue por las importantes reformas que se realizan en la enseñanza y por el trascendental cambio que obtiene la escuela en todos sus elementos. Las condiciones materiales de los edificios, el mobiliario de la clase, los útiles de enseñanza; la distribución del tiempo, los juegos de los alumnos, sus trabajos, los métodos que deben emplearse para conseguir con eficacia el fin de la escuela: todo es materia de grandes estudios, de reglamentaciones especiales y de innovaciones provechosas para el buen éxito de la educación."
} 
educators, writers, booksellers, and editors influenced educational legislation and school culture in Peru.

Several types of institutions that formed this pedagogical public sphere, including newspapers as well as philanthropic, educational and literary associations, each had a late colonial and even older history, but the development of Lima's publishing industry enabled the foundation of Peruvian pedagogical newspapers. These publications communicated the endeavors of diverse individuals involved in private as well as public educational enterprise. As a result, intellectual competitions and pedagogical conferences multiplied in the last three decades of the nineteenth century. This process broadened the public spaces through which "enthusiasts of education" legitimized their schools, teaching methods, textbooks, and other educational endeavors. This is especially true of newspapers published after Arnaldo Marquez's, El Educador Popular. Published in New York, but under the "protection" and financial assistance of Manuel Pardo, this newspaper generally focused on publishing translations of the pedagogical tracts and textbooks of North American or European educators. The newspapers that followed, including Boletín de Instrucción Pública, La Instrucción, El Faro and, later, La Escuela Peruana, became the instruments through which "enthusiasts of education" sought to communicate and influence educational reform as well as school culture.

Lima's pedagogical public sphere involved close collaboration between the state and members of civil society. Jürgen Habermas's classical concept of the "public sphere" describes the development of an autonomous realm within civil society where private 
people conduct reasonable and critical debate over governing issues. ${ }^{423}$ In the case of Lima, most pedagogical newspapers were started as private enterprise, but their founders promptly secured support from the central government. Despite government subsidies, these newspapers offered a critical space for Lima's educators to discuss pressing issues, including textbook standardization, spreading literacy among non-Spanish speakers, and women's education. This chapter thus questions the rigid structures of the classical Habermasian model, which erects a false dichotomy between venues of public exchange and the structures of the state. ${ }^{\prime 424}$

Women constituted a central component within Lima's pedagogical public sphere. They were involved at all levels in the expansion of critical debates over education. They founded their own schools, reorganized public school festivities, incorporating readings of student essays, and participated in textbook and pedagogical contests. ${ }^{425}$ Women's involvement increased after the War of the Pacific. They outnumbered men in one of the most active educational associations of the last decades of the nineteenth century and authored numerous textbooks. ${ }^{426}$ They debated other authors beyond pedagogical

\footnotetext{
${ }^{423}$ Jürgen, Habermas, The Structural Transformation of the Public Sphere: An Inquiry into a Category of Bourgeois Society (The MIT Press, 1991), 27. See also, Geoff Eley, "Nations, Publics, and Political Cultures: Placing Habermas in the Nineteenth Century," in Habermas and the Public Sphere, ed. Craig Calhoun (The MIT Press, 1992), 289-339.

${ }^{424}$ Jeremy L. Caradonna, The Enlightenment in Practice: Academic Prize Contests and Intellectual Culture in France, 1670-1794 (Cornell University Press, 2012), 7.

${ }^{425}$ Ateneo de Lima, Certamen de Textos y Exposición Escolar: Inauguración Jueves 15 de Agosto de 1889 (Lima: Imprenta de la Merced, 1889) and Ateneo de Lima, Certamen de Textos y Exposición Escolar: Distribución de premios y clausura Septiembre 8 de 1889 (Lima: Imprenta y Librerias de Benito Gil, 1889).

426 "Socios fundadores" in Reglamento de La Sociedad de Preceptores (Lima: Imprenta de J. Francisco Solis, 1885), 18.
} 
newspapers in Lima's leading newspaper El Comercio and in other literary periodicals. ${ }^{427}$ Their ideas were not limited to women's education, but often addressed broader questions on educational methods and the highly politicized conversation over the secularization and centralization of public education. Literary critic Francine Masiello has noted that women acquire greater visibility in public life and the affairs of the state during times of national crisis, an observation not lost to a Peruvian contemporary writer. ${ }^{428}$ In 1884 , referring to the increased participation of women in public life shortly after the end of the War of the Pacific, writer Julio F. Sandoval noted that Peruvians were living in a new epoch. ${ }^{429}$ Some literary scholars have pointed out that women writers were shut out of Lima's public sphere during the postwar years. ${ }^{430}$ While this was the case with some women, others increasingly participated in a pedagogical public sphere of educators, writers, booksellers, editors and enthusiasts of education.

${ }^{427}$ Fanning, Educación Femenina, 1. Also see Mercedes Cabello de Carbonera, "La Lectura," El Correo del Perú, January 2, 1876; Clorinda Matto de Turner, "La necesidad de la educación física en los colegios," El Perú Ilustrado, March 8, 1890.

${ }^{428}$ Masiello, Between Civilization and Barbarism: Women, Nation, and Literary Culture in Modern Argentina. (Lincoln \& London: University of Nebraska Press, 1992), 8.

${ }^{429}$ See biographical sketch by Julio F. Sandoval in Clorinda Matto de Turner, Tradiciones cuzqueñas. Leyendas, biografias y hojas sueltas (Arequipa: Imprenta de "La Bolsa"—Guañamarca N. 49, 1884), xiii. Original text: "privada de todo recurso, llegando un dia á la redacción de un diario, pidió trabajo para consequir el sustento. En otra época habria causado hilaridad aquella demanda, pero al presente, no. El Director y propietario de "La Bolsa," conocía el talento y aptitudes de Clorinda y tuvo á fortuna encargarle la redacción en jefe del periódico."

${ }^{430}$ Francine Masiello, La Cigarra y la 25-26. 
The Midcentury Educational Renewal

During the second half of the nineteenth century, Liberal educators and legislators across the Atlantic World sought to reform several aspects of education. This period saw increased collaboration between an emergent public sphere and the state in the interest of fulfilling the republican promise of universalizing primary education. Latin American reformers hoped to promote the expansion of education to all classes and modernize the administration of schools through legislation. Domingo Sarmiento of Argentina, Pedro Varela of Uruguay, Benito Juarez and Gabino Barreda of Mexico figure prominently in national historiographies as authors or promoters of sweeping Liberal educational codes that generally endorsed making education compulsory, free, and secular. ${ }^{431}$ Teacher sand pedagogues hoped to redefine education as a science in both its theory and methodology through pedagogical literature, a process they hoped would help professionalize the teaching profession and improve the quality of learning in schools. ${ }^{432}$ Often soliciting government support, they founded and promoted the publication of pedagogical newspapers. In addition to including instructional content in the various arts and sciences, these newspapers also addressed teaching methods and theory. ${ }^{433}$

\footnotetext{
${ }^{431}$ See Miguel Angel Marco, Sarmiento: maestro de América, constructor de la nación (Emecé, 2016); Jorge Bralich, “José Pedro Varela y la gestación de la escuela uruguaya," in Revista de Historia Latinoamericana, No. 17 (July 2011): 43-70; Charles Hale, The Transformation of Liberalism in Late Nineteenth-Century Mexico (Princeton University Press, 1989).

432 Carmen McEvoy, "Estudio Preliminar" in Recuerdos de viaje a los Estados Unidos de la América del Norte (1857-1861) by Arnaldo Márquez (Lima: Fondo Editorial UNMSM, [1862] 2003), 23.

${ }^{433}$ Irma Leticia Moreno Gutiérrez lists 61 titles of pedagogical newspapers or magazines published in Latin America between 1870 and the first decade of the twentieth century, see "La prensa pedagógica en el siglo XIX," in Diccionario de Historia de la Educación en México ed. Luz Elena Galván Lafarga (México: CONACyT-CIESAS, 2002). Also see appendix 8 in Ernesto Meneses Morales, Tendencias educativas oficiales en México, 1821-1911 (México: Universidad Iberoamericana, 1998), 901-905.
} 
The content of pedagogical newspapers rejected traditional teaching through memorization and recitation and promoted the use of the intuitive method, which had evolved from the naturalist pedagogy of Comenius, Rousseau, Pestalozzi, Spencer and others. ${ }^{434}$ It emphasized that children learned best through using sensory experience to examine objects in their immediate environment. The expertise required to teach using sensory experience and children's intuition placed the newer methods at odds with the Lancasterian method, which relied heavily on the assistance of student helpers. Professors Andrew Bell and Joseph Lancaster had developed the system for the education of the poor in Britain, but the method spread in Peru and much of Latin America during the first half of the nineteenth century. ${ }^{435}$ Many of the textbooks used to support teaching through the Lancasterian method were explicitly written in the catechistic (question and answer) format to promote learning through memorization and recitation. ${ }^{436}$ Advocates of the intuitive method thus faced the task of retraining teachers in the new methods, training new teachers, and promoting the publication of literature that reflected newer teaching methods.

In Peru, national education had been the subject of increased legislative reform after Liberals led a successful revolt in 1854. Under the leadership of President Ramón Castilla during his second presidency (1855-1862) and the influence of educator Sebastián Lorente, they passed the Educational Code of 1855, which emphasized the need to educate the lower

\footnotetext{
434 "La Educación en los Estado Unidos considerada como Industria" and "Manual de Lecciones sobre objetos Tratado de Instrucción Elemental para Padres i Maestros por N. A. Calkins," El Educador Popular, May 15, 1873.

${ }^{435}$ Eugenia Roldán Vera, "Reading Questions and Answers: The Catechism as an Educational Genre in Early Independent Spanish America," Book History, Vol. 4 (2001), 30.

${ }^{436}$ Eugenia Roldán Vera, The British Book Trade and Spanish American Independence: Education and Knowledge Transmission in Transcontinental Perspective (Burlington: Ashgate, 2003), 147.
} 
classes through a program of "popular instruction." ${ }^{\text {"37 }}$ The code outlined the subjects to be taught in primary and vocational schools, but omitted regulation on grade levels and methods, and made no commitments regarding the role of the central government in providing teachers with educational and pedagogical reading material. These matters received more attention during the rise of Manuel Pardo (1872-1876) and the Civilista Party, which supported several educational reforms aimed at modernizing school curricula, instituting compulsory and free public education, and making school administration more efficient. ${ }^{438}$ Educators also hoped to improve women's education, a subject much debated by Teresa González de Fanning, Mercedes Cabello de Carbonera and their male colleagues during the literary gatherings of writer Juana Manuela Gorriti and in Lima's newspapers. ${ }^{439}$ To improve women's ability to achieve financial independence, these elites advocated for a more practical, rather than decorative curriculum in women's education. They were especially concerned with Peruvian women who remained unmarried or became widowed, circumstances that often left them precarious financial situations. ${ }^{440}$

${ }^{437}$ See "Reglamento de Instrucción Pública" passed on April 7, 1855 in Juan Oviedo, Colección de Leyes, Decretos y Ordenes publicadas en el Perú desde al año 1821 hasta el 31 de diciembre de 1859 (Lima: Felipe Bailly, 1862), 242-246.

438 "Reglamento General de Instrucción Pública del Perú (Lima: Imprenta del Estado, 1876). On the rise of Pardo and the Civilista Party, see Carmen McEvoy, La Utopía Republicana: Ideales y Realidades en la Formación de la Cultura política Peruana (1871-1919) (Lima: Pontificia Universidad Católica del Perú, 1997).

${ }^{439}$ Mercedes Cabello de Carbonera, "Influencia de la Mujer en la Civilización" El Correo del Perú, December 31, 1874. Teresa González de Fanning, "Trabajo para la mujer;” Mercedes Eléspuru y Lazo, "La instrucción de la mujer;" Alamos González, Benicio, "Enseñanza superior de la muger," in Obras Completas, ed. by Juana Manuela Gorriti (Buenos Aires: Imprenta Europea, 1892). On the "first generation of lettered women in Peru," see Francesca Denegri, El Abanico y la Cigarrera: La primera generación de mujeres ilustradas en el Perú (Lima: IEP, 2004) and Maria Emma Mannarelli, Las mujeres y suspropuestas educativas, 1870-1930 (Lima: Derrama Magisterial, 2013).

${ }^{440}$ Ibid, 252. 
Within this cultural and political conjuncture, Peruvian polymath Arnaldo Márquez solicited financial support for a pedagogical newspaper from the Peruvian government. ${ }^{441}$ Born in 1832 to impoverished middle-class parents, but educated with the support of scholarships and assistantships in the prestigious Convictorio de San Carlos, Márquez grew accustomed to working close to Lima's powerful ruling class. ${ }^{442} \mathrm{He}$ secured Manuel Pardo's support for his pedagogical newspaper El Educador Popular (1873-1877), which became the first of its kind to be financed by the Peruvian central government. The educational code of 1876, passed by Civilista leadership, ordered that copies of the periodical be distributed to Peruvian municipalities. ${ }^{433}$ Márquez edited the newspaper while residing in New York, where he summoned the help of a group of Liberal Cuban exiles including historian and bibliographer Antonio Bachiller Morales and professor of languages Luis Felipe Mantilla, as well as prominent annexationists, lawyer José Ignacio Rodriguez and editor-bookseller Néstor Ponce de León. ${ }^{444}$

\footnotetext{
${ }^{441}$ Carmen McEvoy, La Utopía Republicana, 154.
}

${ }^{442}$ See Teodomiro Gonzáles Elejalde, José Arnaldo Márquez; la época, su vida, sus obras (Lima: Tall. Tip. De la Penitenciaria, 1915) and Carmen McEvoy, "Estudio preliminar" in José Arnaldo Márquez, Recuerdos de viaje a los Estados Unidos, 1857-1861 ed. Carmen McEvoy (Lima: Fondo Editorial de la UNMSM, [1862] 2003), 17-18.

${ }^{443}$ The periodical began to circulate in 1873 and the school code of 1876 ordered its continued distribution, see "capitulo xi" in Reglamento de Instrucción Pública (Lima: Imprenta del estado, 1876), 22. Also see $E l$ Educador Popular (New York), April 30, 1877.

${ }^{444}$ El Educador Popular (New York), May 15, 1873. Mantilla authored numerous books including Gramática infantil para los niños americanos (New York: Librería de N. Ponce de León, 1879) and a collection of three reading books published under the title of Libros de Lectura (New York: Ivison, Blackeman, Taylor and Co. Editores, 1865), several of which were published in El Educador Popular. Antonio Bachiller Morales publishied Cuba primitiva, origine, lenguas, tradiciones e historia de los Indios de las Antillas Mayores y las Lucayas (Habana: Librería de Miguel de Villa, 1883). José Ignacio Rodriguez was a government bureaucrat and writer who later authored Estudio histórico sobre el origen, desenvolvimiento y manifestaciones prácticas de la idea de la anexión de la isla de Cuba a los Estados Unidos (Habana: Imprenta La Propaganda Literaria, 1900). Néstor Ponce de León authored Diccionario tecnológico inglés/español (English/Spanish Technological Dictionary (New York: Librería de N. Ponce de León, 1906-1910) and founded the Librería de N. Ponce de León in New York, which also published $E l$ 
Through the pages of El Educador Popular, Márquez and the group of Cuban exiles wanted to promote the system of education implemented in the United States, as well as some of the most recent pedagogical literature published in that country. In 1873, they serialized a translation of Primary Object Lessons, written by United States educator Norman Calkins. Calkins had simplified Pestalozzi's abstract principles into a practical manual for teachers. ${ }^{445} \mathrm{He}$ published the first edition in 1861, but it was not until the publication of the 1870 edition that the manual became popular in the United States and beyond. Uruguayan education reformer José Pedro Varela had also previously published a translation of Calkins's work in $1872 .{ }^{446}$ Calkins emphasized that before exposing children to words, teachers needed to introduce children to the physical objects represented by words. The manual included a series of lessons on forms, colors, numbers, sizes, drawing, time, sound, primary reading, qualities of objects, human body, and moral training, which provided teachers with practical scripts and suggestions for their interactions with children.

Reading excerpts in El Educador Popular also reflected the U.S.-centrism of Márquez and his Cuban contributors. They used historical figures of the United States as models of exemplary citizenship. They included biographies of Benjamin Franklin and George Washington adapted with moralistic maxims for children's reading. One excerpt emphasized that Benjamin Franklin was a distinguished citizen who had sacrificed countless hours that could have been dedicated to physical activity or leisure to

\footnotetext{
Educador Popular. Also see Carlos Ripoll, Cubans in the United States (New York: Las Américas Publishing Co., 1987), 9-20.

${ }^{445}$ Norman Calkins, Primary Object Lessons for Training the Senses and Developing the Faculties of Children (New York: Harper \& Brothers, 1873), 15-23.

${ }^{446}$ José Pedro Varela, La educación del pueblo (Montevideo: Tipografía de “La Democracia," 1874), 241.
} 
"methodically educating his reason" (educo metódicamente su razón). ${ }^{447}$ Franklin’s exemplary merit and talent, the excerpt noted, had earned him the best employment in service of his country. He became statesman, ambassador, and man of letters and received praise after his death by the French national assembly. The newspaper also published excerpts from Benjamin Franklin's, Poor Richard's Almanac, which emphasized industriousness and frugality. ${ }^{448}$ Another reading presented the life of "Jorge" Washington. It chronicled how a six-year-old Washington had used an axe he had recently received as a gift to destroy everything that came in his path. When his father found his favorite fruit tree destroyed, he asked the younger Washington if he knew what had happened. The virtuous child responded "You know father, that I do not lie...I never lie. I cut it myself with a little axe without realizing the harm I was doing, but now I understand and I ask for your forgiveness." ${ }^{449}$

Images in the El Educador Popular often displayed North American architecture. Several issues published images of buildings in North American universities, colleges and other educational institutions. An issue from July of 1876 described several buildings in Philadelphia, which at the time was housing the American Centennial Exhibition where thirty-seven countries participated, showcasing achievements in the arts, manufacturing, agriculture and mining. ${ }^{450}$ Taking up nearly four pages of the sixteen-page periodical, the

\footnotetext{
447 “Benjamin Franklin,” El Educador Popular, August 15, 1873.

448 “La ciencia del buen hombre Ricardo por Benjamin Franklin,” in El Educador Popular, July 30, 1876.

449“Jorge Washington," El Educador Popular, August 31, 1873. Author's emphasis, original text: "Ya sabeis Papá, que yo no digo mentiras...nunca digo mentiras. Yo mismo lo corté con una hachita, sin comprender que hacia un daño; mas ahora lo comprendio i pido me perdonéis."

450 “Edificios de la Exhibición de Filadelfia,” El Educador Popular, July 15, 1876.
} 
issue described and published images of the buildings used in the exhibition including Memorial Hall, Machinery Hall, Agricultural Hall, and the Horticultural Hall. The description of Memorial Hall provided detail about its size, modern architecture and costly granite, glass and iron construction to prevent fires. It described its windows, entryways, lighting, and galleries, and provided a full-page image of the building (see Figure 3). A promotional trade card for the exhibition appeared in another full-page display showcasing Machinery Hall (see Figure 4). Its imagery emphasized the technological and architectural modernity being displayed in the North American city. 
Figure 3. Palacio de Bellas Artes en la Exposición de Filadelfia

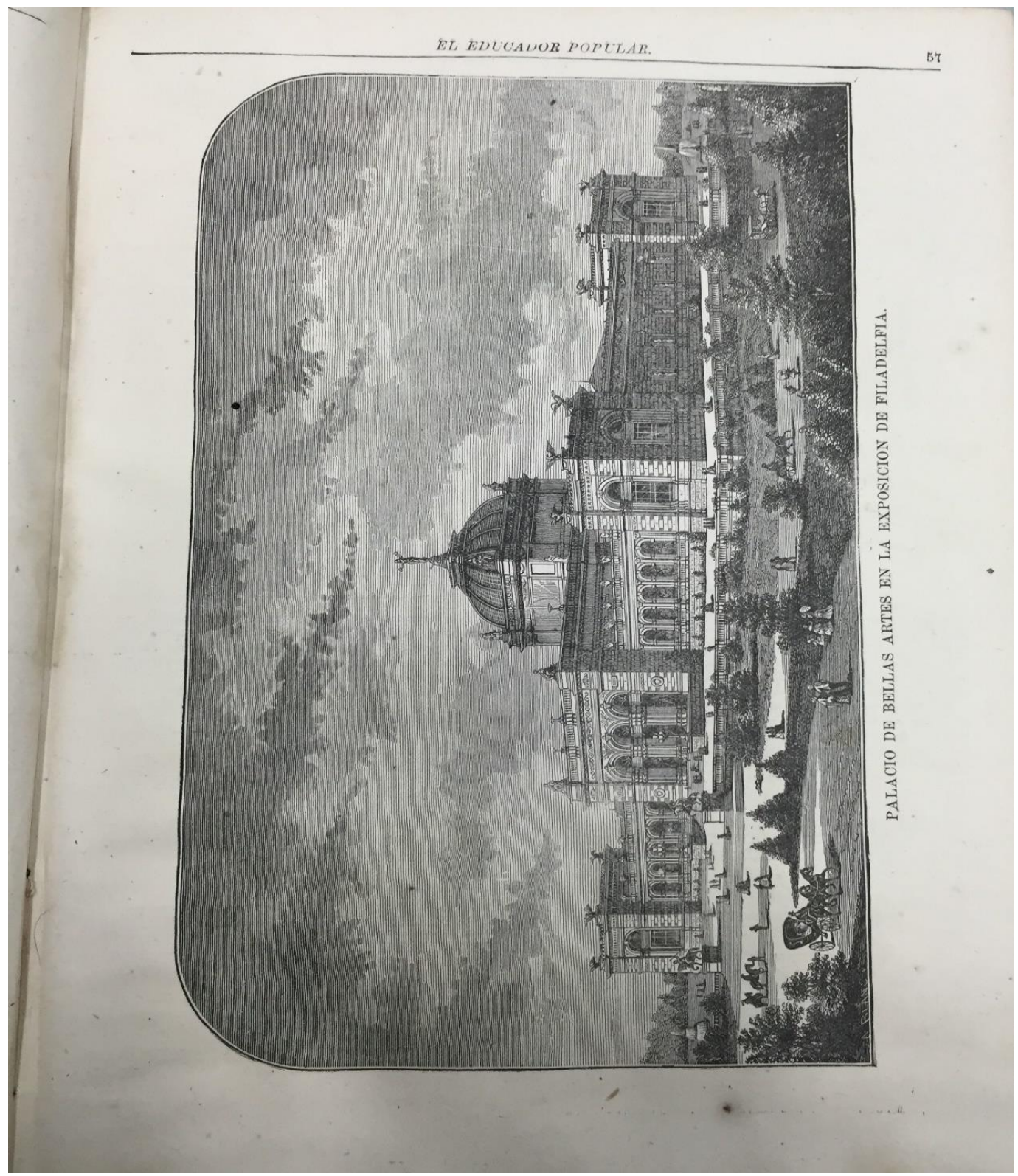

Source: "Palacio de Bellas Artes en la Exposición de Filadelfia," El Educador Popular, July 15, 1876. 
Figure 4. Palacio de Maquinaria en la Exposición de Filadelfia

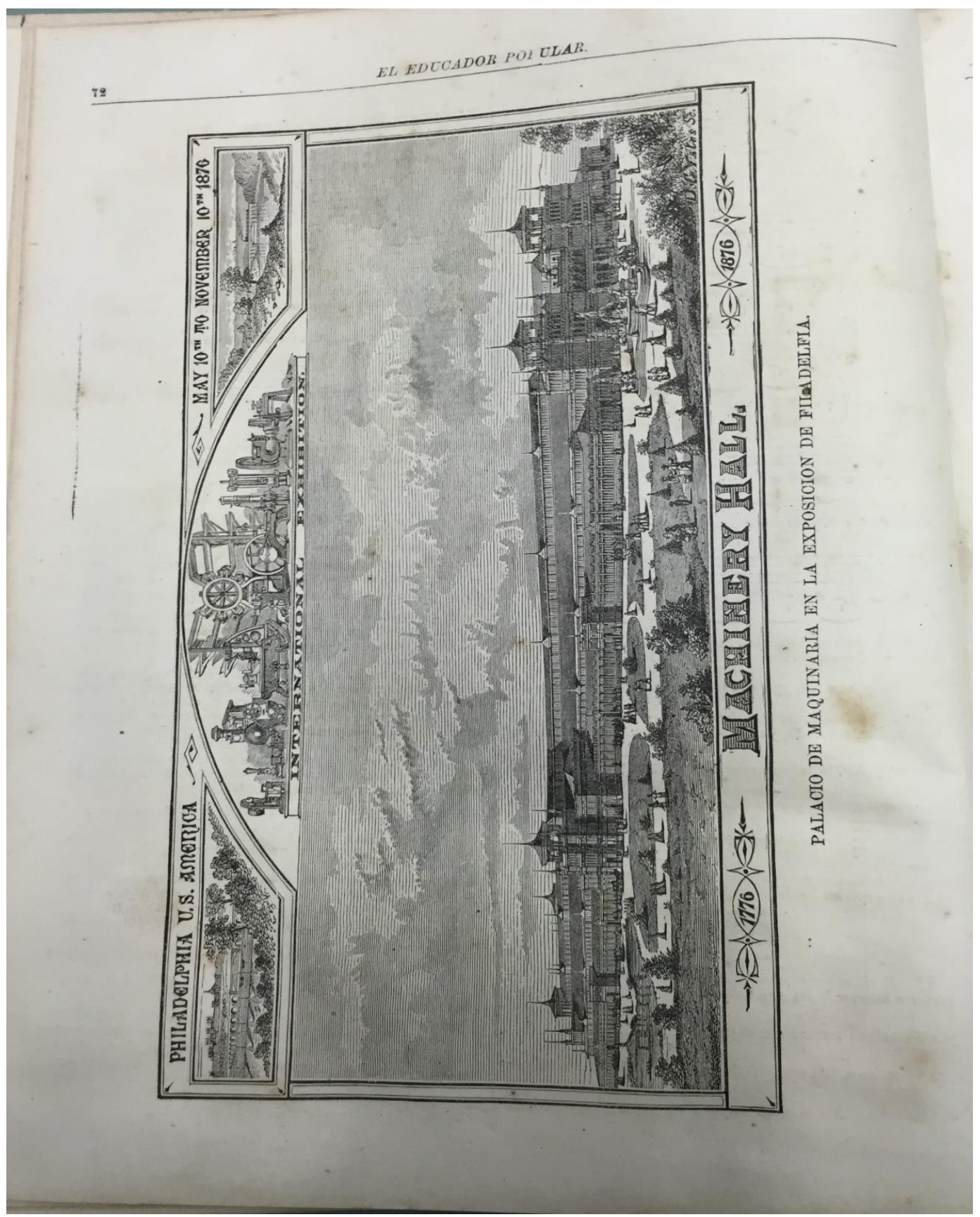

Source: "Palacio de Maquinaria en la Exposición de Filadelfia," El Educador Popular, July 15, 1876.

In his serialized article on North American education, Antonio Bachiller emphasized his admiration for that country's educational legislation, which according to 
the author, made no curricular distinctions in the instruction of men and women. In the following lines, however, he noted that American educational institutions could be aptly called "schools for mothers." 451 He noted that this system, if implemented in Spanish America, would not be new since the economic society of Amigos del País had disseminated a similar system in the late eighteenth century. The writer emphasized that educating women would not turn them into men or "marisabidillas," but as other educators in the Atlantic World did, he embraced a gendered ideology, which promoted the education of women in order to help them better fulfill their "natural" mission as mothers. ${ }^{452}$ The author described the curriculum instituted in the recently established Girls New York College. It included philosophy, physics, chemistry, German, French, natural sciences, music, astronomy geometry, algebra, Latin, zoology, rhetoric, teacing methods, drawing, botany, modern history, bookkeeping, calligraphy, and ancient history. The article ended with a lengthy description of the new building, which housed the normal school (see Figure $3) .{ }^{453}$

\footnotetext{
${ }^{451}$ Antonio Bachiller, “La Educación en los Estado Unidos. XI,” El Educador Popular, October 15, 1873.

${ }^{452}$ Several scholars have advanced our views of the uses of gender ideology by the state and social institutions to confine women to socially acceptable work, which emphasized the role of women as nurturers. These scholars have also argued that gendered thinking similarly circumscribed the scope of topics that women writers discussed in the "public sphere." See for example, Silvia Arrom, The Women of Mexico City, 1790-1857 (Stanford: Stanford University Press, 1985); Aurora Morcillo, True Catholic Womanhood: Gender Ideology in Franco's Spain (DeKalb: Northern Illinois Univesity Press, 2000). Asunción Lavrín has argued women used an "ideology of social mission based on gender functions and attributes" to justify their participation in politics, see Women Feminism, and Social Change in Argentina, Chile, and Uruguay, 1890-1940 (Lincoln and London: University of Nebraska, 1995). Also see Sueann Caulfield, "The history of Gender in the Historiography of Latin America," Hispanic Ameircan Historical Review 81: 3-4 (2001); Elizabeth Dore and Maxine Molyneux, Hidden Histories of Gender and the State in Latin America (Duke University Press, 2000).

${ }^{453}$ For example "Universidad de Nueva York," El Educador Popular, August 15, 1873; "Colegio Normal de Señoritas," El Educador Popular, October 15, 1873; "Instituto Cooper," El Educador Popular, November 30, 1873; "Biblioteca Mercantil de Nueva York," El Educador Popular, November 15, 1873;
} 
Figure 5. Colegio Nacional de Señoritas

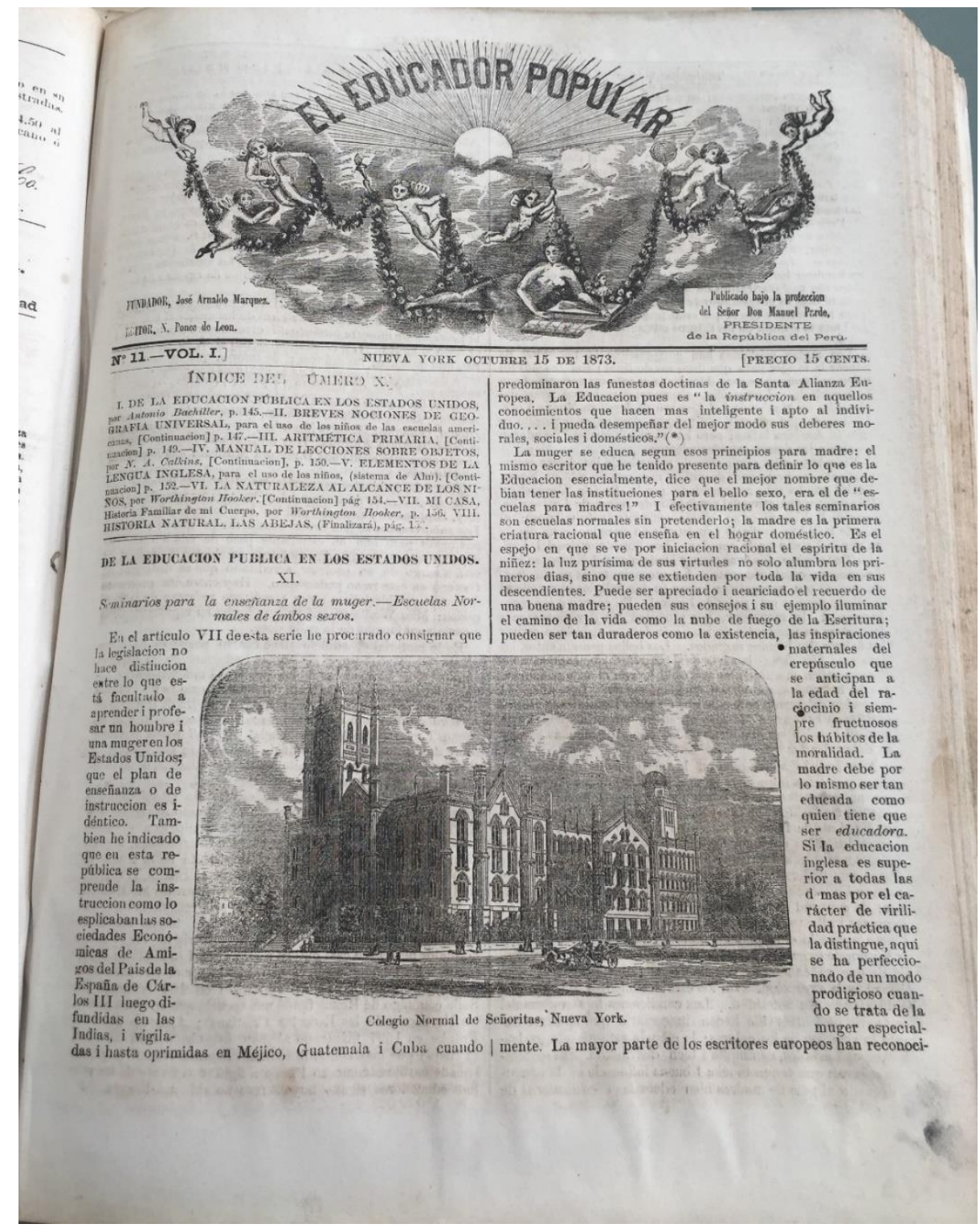

Source: “Colegio Nacional de Señoritas,” El Educador Popular, October 15, 1873.

To make the newspaper more appealing to its multinational Latin American audience, Márquez and his contributors serialized texts about a broad range of subjects. They included texts on arithmetic and geometry, and a strong emphasis on the physical and natural sciences-physical geography, geology, botany, chemistry, astronomy, and 
anatomy. ${ }^{454}$ The subjects of geography and history had a universal approach rather than a focus on Peru. The newspaper published Geografía Universal by Bachiller, which began with general information on North and South America, Europe, Asia and Africa, followed by descriptions of countries within these continents. The texts presented brief sketches of the physical limits and landscapes of countries, their climates, industries, a brief list of historical figures and places, and political divisions. The section on Peru appeared without emphasis in two pages, as did most of the other countries. ${ }^{455}$ The newspaper also published several sections of Bachiller's Historia Universal, but the sections were limited to descriptions of the early civilizations of Europe, Egypt, Syria and China.

The subject of religion appeared from an analytical and metaphysical perspective, rather than a purely dogmatic one, noting that the objective was to "define and explain what is understood by Religion." ${ }^{456}$ It defined religion in relationship to morality, arguing that the latter is innate and universal in all places because it originates in God. Religion, however, gave form to an otherwise unintelligible morality, connecting man with God. The second part of the text described the dogmas of the principal cults of the world and their relationship to religion.

El Educador circulated profusely in Lima and other parts of Peru, causing controversy because of its emphasis on the natural sciences and eclectic approach to religion. The government of Manuel Pardo subscribed to two thousand copies per issue

\footnotetext{
454 “Textos publicados en El Educador Popular,” El Educador Popular, Abril 15, 1877

455 “Lección décima. Perú,” El Educador Popular, June 30, 1873.

456 “'Religion, por H,"El Educador Popular, July 30, 1876. Author's empahsis, original text: “Este tratado tiene por objeto definir i esplicar lo que se entiende por Religión."
} 
and these issues were distributed widely throughout public schools in Peru. ${ }^{457}$ One "notorious incident" from 1874 described its broad circulation in Arequipa, as well as the adverse reaction it provoked among conservatives in that city because it dismissed the existence of one true religion. ${ }^{458}$ Local priest José María Masiá condemned the newspaper as "irreligious." Fearing the propagation of these ideas in schools where El Educador was "distributed profusely," the priest declared that the newspaper should not circulate freely and that parents should not send their children to schools where the doctrines of the newspaper were taught. ${ }^{459}$ The same account noted that the most distinguished women asked the bishop to prohibit the circulation, public reading and teaching of the maxims and readings contained in the El Educador Popular. They marched to the central plaza where they burned issues of the newspaper and a portrait of Márquez in an "inquisitorial stake." "460 Despite its controversial content, the government of Manuel Pardo continued to support the publication through April of 1877.

The process of modernizing Peruvian education also involved reorganizing civic festivities around educational or intellectual competition. ${ }^{461}$ Civic festivities were ordered by the national government, but generally organized by town councils and members of

\footnotetext{
457 “Sueldos y gastos de instrucción primaria,” El Peruano, November 22, 1873.

${ }^{458}$ Gonzáles Elejalde, José Arnaldo Márquez; la época, su vida, sus obras, 39. González did not include footnotes in his brief biography of Márquez, but he appears to have collected information on this incident through oral accounts, noting in one excerpt that "he has been assured" of these events.

${ }^{459}$ Ibid, 39.

${ }^{460}$ Ibid, 40.

${ }^{461}$ On concours culture or contestatory culture, see Jeremy Caradonna, The Enlightenment in Practice: Academic Prize Contests and Intellectual Culture in France, 1670-1794 (Cornell University Press, 2012), 4.
} 
various associations. Based on midcentury descriptions of civic events, they had long lacked enthusiasm from participants. In 1848, an account of civic festivities described the commemoration of Peruvian Independence as lukewarm and less enthusiastic than those of contemporary nations which conserve an "everlasting ardent spirit."462 In his 1866 description of public life in Lima, Manuel Atanasio Fuentes noted that civic festivities barely deserved mention. He described the halls of the Casa Municipal and the Palacio as adorned with white and red frills and some ordinary wall hangings with paintings that had no special meaning. ${ }^{463}$ Moreover, Fuentes commented on the deteriorated state of government buildings, which resembled a "pigeon loft" (palomar) instead of government buildings.

Incorporating contest-driven practices or encouraging "contestatory culture," as conceptualized by historian Jeremy Cardonna, offered an opportunity to enhance the participation of Peruvian citizens in civic festivities while edifying the official nationalist rhetoric that praised hardworking citizens in service of the nation. ${ }^{464}$ Contestatory culture encouraged competition, prizegiving, and public recognition. These acts evolved out of practices from Ancient Greece where poetry and oration contests judged the best oral performances. They influenced emerging medieval university teaching leaving a

\footnotetext{
462 “Algo de todo," El Comercio, August 2, 1848.

${ }^{463}$ Manuel Atanasio Fuentes, Estadística General de Lima (Paris: Tip. De A. Lainé et J. Havard, 1866), 454-455.

${ }^{464}$ On concours culture or contestatory culture, see Jeremy Caradonna, The Enlightenment in Practice: Academic Prize Contests and Intellectual Culture in France, 1670-1794 (Cornell University Press, 2012), 4.
} 
longstanding legacy ${ }^{465}$ During the eighteenth century, contestatory culture extended beyond the university as literacy improved throughout Europe and intellectual contests accepted participants "from a wide range of social classes, geographical locations, and national origins. ${ }^{~} 466$ The belief that prizegiving and public recognition would encourage emulation undergirded efforts to systematize competitive practices particularly within primary education in the early nineteenth century ${ }^{467}$ Republican legislation in Peru thus ordered these practices within normal and primary schools as early as $1822 .{ }^{468}$ As with educational reforms, however, broad efforts to institute competitive public contests within cultural, scientific, artistic and educational fields intensified during the second half of the nineteenth century.

During the 1870s, several laws addressed prizegiving within distinct cultural and educational fields. In 1873, for instance, President Manuel Pardo ordered that San Marcos hold an annual literary contest about general subjects of interest, but emphasizing the history of Peru. The contest was to take place every year on July 28 during the commemoration of Peruvian Independence, and the winner was to receive a prize of 5 thousand soles. The law also required that new universities throughout the country hold a

\footnotetext{
${ }^{465}$ Mary R. Lamb, "Introduction" in Contest(ed) Writing: Re-Conceptualizing Literacy Competitions (Cambridge Scholars Publishing, 2013), 4.

${ }^{466}$ Jeremy Caradonna, The Enlightenment in Practice, 6.

${ }^{467}$ See "Emulation and Rewards" in Joseph Lancaster, The Lancasterian System of Education, with Improvements (Baltimore, 1823), 23. Also see Gabriel Compayré, Lectures on Pedagogy Theoretical and Practical (Boston: D.C. Heath \& Co., Publishers, 1887), 455.

${ }^{468}$ See "Disponiendo que se establezca en Lima una escuela normal central," Juy 6, 1822 and "Previniendo á los Prefectos que exciten á los gobernadores eclesiásticos para que cuiden que en los conventos se establezcan las escuelas de primeras letras de que se encarga el decreto de 23 de Febrero de 1823," May 30, 1830 in Colección de Leyes, 7 and 17.
} 
similar contest. Town councils also needed to conduct their own contests within their jurisdictions and emphasize subjects of social interest, giving preference to works that articulated improvements within their departments. ${ }^{469}$ In 1877, President Mariano Ignacio Prado ordered a similar contest, but within a broader range of subjects. ${ }^{470} \mathrm{He}$ also ordered the organization of a contest among army chiefs and officials for the composition of a treatise on weaponry. ${ }^{471}$ The 1879 regulations for the national library ordered that frequent library users who read scientific or literary works be recommended for an honorary prize that would be given away during civic festivities. ${ }^{472}$

During the same decade, the government took steps to provide more adequate public space for civic activities, particularly as plans were under way to organize the country’s first national exposition. President José Balta had ordered the construction of the Palacio de la Exposición for this purpose. It was successfully inaugurated on July 1, 1872. ${ }^{473}$ The first exposition included a book contest, which awarded Peruvian author and engineer Florentino Barreto y Helguero for his textbook on line, geometric, and architectural drawing. ${ }^{474}$ Thereafter, the building and its surrounding park housed national

\footnotetext{
469 "Disponiendo que la Universidad Mayor de San Marcos provoque anualmente un concurso literario sobre asuntos de interés general y principalmente sobre la historia del Perú," July 26, 1873, ADLP.

470 “Aperturando un concurso nacional científico en la Universidad Mayor de Lima y estableciendo disposiciones para llevarlo a cabo,” November 15, 1877, ADLP

471 "Convocando concurso entre jefes y oficiales del ejército para la redacción de un tratado sobre artillería," June 8, 1878, ADLP.

472 “Reglamento para la Biblioteca Nacional de Lima,” May 12, 1879, ADLP.

${ }^{473}$ Francisco A. Fuentes, Catalogo de la Exposición Nacional de 1872 (Lima: Imprenta del Estado, 1872), 5.

${ }^{474}$ Francisco A. Fuentes, Catálogo de la Exposición Nacional de 1872 Edición Oficial (Lima: Imprenta del Estado, 1872), 307.
} 
expositions and civic festivities, which often took place on the same days. During the civic festivities of 1876, educator Enrique Benites received a gold medal for his textbook Geografía del Perú, and author Manuel García Merino received another for his work Epidemias de las plantas en la costa del Perú ${ }^{475}$ The program for the 1877 civic festivities included an artistic exposition of flora at the public building. As part of the program, attendants would hear the public reading of the best essay addressing the influence of the fine arts on the moral and material progress of different societies. The winner would be awarded a gold medal and a diploma by a corresponding committee. ${ }^{476}$

Peruvian politicians as well as members of cultural and educational associations encouraged the merging of intellectual contest with civic festivities, a process that invigorated civic celebrations. The events of 1878, also at the Palacio de la Exposición, framed a "solemn distribution of awards" according El Comercio. ${ }^{477}$ The hall was full to capacity. Among the attendants were school children from the municipal schools of both sexes, teachers, professors, and representing members of military bodies and several fire departments. Both the Department of Lima and the provincial council awarded various medals to students, teachers, firemen, textbook writers, editors, school inspectors, and more.

The organizing commissions ensured that women figured prominently as awardees, speakers, performers, and spectators. Isabel Guzman de Bressler received medals for her

\footnotetext{
475 “Fiestas Cívicas," El Comercio, August 1, 1878.

476 "28 de Julio,” El Comercio, July 17, 1877.

477 “Fiestas Cívicas,” El Comercio, August 1, 1878.
} 
work as founder and editor of the pedagogical newspaper, Boletín de Instrucción Pública. Armecinda Torres de Raigada received another medal for her "morality" and dedicated work as the first woman to work as telegrapher in Peru. Similarly, Emilia Monzón viuda de Bermeo received a medal for becoming the first woman to "practice" (ejercer) photography. ${ }^{478}$ Women participated in several musical performances and writer Mercedes Cabello de Carbonera read a work of history that had previously been published by Lima's daily El Comercio. According to the same newspaper, no other celebration in Lima had ever seen such a large female audience (nunca se ha visto en una fiesta de Lima mayor concurrencia de señoras). ${ }^{479}$

The representation of women in this civic celebration can be better understood within the context of the influence of Lima's "first generation of lettered women" and more broadly, the educational renewal of the period. To one of these literatas it had become customary to "chime into the conversation" (meter su cuchara). ${ }^{480}$ These women benefited from the dynamic print culture that emerged in Lima by the 1870s. Several decades of economic prosperity as a result of the guano boom had also stimulated a lively print industry. While their rhetoric was limited in political scope, since they did not advocate for women's participation in politics, their writing linked women's education with the prosperity of the nation. Female writers and some of their colleagues stressed the need of

\footnotetext{
${ }^{478}$ Ibid.

${ }^{479}$ Ibid.

${ }^{480}$ Mercedes Eléspuru y Lazo, "La instrucción de la muger" in Obras completas, ed. Juana Manuela Gorriti (Buenos Aires: Imprenta Europea, 1892), 122.
} 
instituting more practical training for women to increase their participation in the labor market. $^{481}$

The work of Teresa González de Fanning is emblematic of the educational thought of this generation of women. González de Fanning emphasized the social differences between men and women. She explained that women's perils began at birth. While parents celebrated the birth of male children, they quickly lamented the birth of female offspring. She argued that women's grim prospects derived from the prejudices and practices of Peruvian society. The education of males was more complex while women's education remained confined to decorative subjects. This left unmarried or widowed women subject to economic dependency on their families. According to the author, this problem pervaded Lima's society. Although she recognized her lack of statistics, she observed that in Lima's society, many women remained unmarried and vulnerable to economic perils. She highlighted that marriages in Lima were not in proportion with the number of people. The high mortality rates for men and their abuse of alcohol and other vices exacerbated the problem of widowed women and unmarried women, often labeled solteronas. Worse still, women in such precarious situations became the subject of society's cruelty and mockery. The writer argued that women needed to be taught an art, a profession or trade that was proportionate to their gender and social position and would develop their intelligence. Further, she emphasized that educating women would limit the number of marriages of

\footnotetext{
481 Teresa González de Fanning, "Trabajo para la muger," in Obras Completas, ed. by Juana Manuela Gorriti (Buenos Aires: Imprenta Europea, 1892), 215.
} 
convenience (matrimonios por convenencia) because women would gain the financial freedom that could save them from prostituting their bodies. ${ }^{482}$

Lima's "Public Sphere" of Pedagogical Society

The work of women educators became foundational broadening the "public sphere" of pedagogical society in Lima. While Arnaldo Márquez promoted the dissemination of $E l$ Educador Popular in Peru, it was Isabel Guzmán de Bressler who founded the first pedagogical newspaper published in Peru. She published the first issue of Boletin de Instrucción Pública (1877-1880) in July of 1877, shortly after the publication of the last issue of El Educador. ${ }^{483}$ Different from El Educador, which lacked Peruvian content or work written by Peruvian authors, the Boletín received contributions from Lima's local educators including Agustín La Rosa Toro, Enrique Benites and Spanish-born Sebastián Lorente. Bressler included educational decrees and laws as well as articles about education. The founder of Boletín had previously published Nociones prácticas de Gramática Castellana, securing approval for the use of the grammar textbook in primary schools from the Concejo Superior de Instrucción Pública in July of $1876 .{ }^{484}$ By January of 1878 , Bressler had also secured a government monthly subscription of fifty issues for her

${ }^{482}$ Ibid, 215

483 "Boletín de instrucción pública" El Comercio (Lima), June 19, 1886. Issues of Boletín de Instrucción Pública from July 15, 1877 through June of 1880 can be found at the Hemeroteca-Coleccion Especial, Biblioteca Central, Pontificia Universidad Católica del Perú (PUCP).

${ }^{484}$ See Isabel Guzmán de Bressler, Nociones prácticas de Gramática castellana para la enseñanza primaria con más de 300 ejercicios (Lima: Empresa Tipografica Camaná, 1876); "Isabel Guzmán de Bressler, Lima, July 10, 1876 in Filiberto Ramirez, Leyes y resoluciones vigentes en materia de Instrucción expedidas desde 1876 (Lima: Imprenta y Litografia de Peter Bacigalupi \& C., 1891), 100. 
pedagogical newspaper. This was a more modest subsidy than that of El Educador, but by 1878, a disastrous mix of global recession and resource exhaustion had ended the guano boom of the previous decades, leaving the Peruvian government in a fiscal crisis. The Dirección General de Instrucción ordered that issues of Bressler's newspaper be distributed among members of the Concejo Superior de Instrucción Pública, universities and secondary schools (colegios de instrucción media). ${ }^{485}$ It was published for four years by the government's Imprenta del Estado. ${ }^{486}$ The publication of this newspaper in Lima came to an end shortly after the Chilean army invaded the capital in $1880 .{ }^{487}$

Several pedagogical newspapers emerged after the war including El Faro, which extended an invitation for pedagogues to contribute to the publication and asked teachers to submit data on their schools and suggestions regarding reforms they deemed relevant to improving education. The newspaper was founded by local primary school teacher and director Juan Ramos y Palacios and edited by bookseller Juan Galland during the last years of his life. Ramos secured support from high level government officials, including President Andrés Avelino Cáceres and Minister of Education Guillermo Seoane, but the newspaper still offered room for debate concerning educational issues. ${ }^{488}$ It published not only official legislation, but also legislative projects that were still the subject of debate

\footnotetext{
485“Boletín de Instrucción Pública,” El Comercio, January 3, 1878.

${ }^{486}$ Mariano Felipe Paz Soldán, Biblioteca Peruana (Lima: Imprenta Liberal, 1879), 9.

${ }^{487}$ According to another article from El Comercio, Bressler and her husband continued the publication after the War of the Pacific. By 1886, they were publishing the periodical from Paris and had renamed it "Boletín de instrucción pública. Revista quincenal ilustrada, dedicada á España y las repúblicas de Centro y Sud-americanas." Teachers in Lima could subscribe at the Libreria Clasica y Cientifica. See "Boletín de instrucción pública" in El Comercio (Lima), June 19, 1886.

488 “El Faro,” El Faro, November 1, 1889.
} 
within congress or the Consejo Superior. ${ }^{489}$ El Faro thus existed as a critical outlet even as the state provided significant support for the newspaper. For state actors who embraced tenets of positivism in the postwar years, critical debate in newspapers offered an opportunity for the state to find experts and expert knowledge for the organization of Peruvian education.

La Instrucción, edited by San Marcos Professor and Dean of the Faculty of Sciences Enrique Guzmán y Valle and administered by the Librería Francisco Grau y Cot, established its mission to promote critical debate about education in its first editions. Guzmán believed education should be organized according to Peruvian reality and cultural identity. While he rejected traditional methods, he believed education needed to be adapted to local, regional and national development. Guzmán founded the periodical as a private endeavor, but promptly secured a government subscription of 80 soles per month for a year. ${ }^{490}$ In the second issue, the editor made a call to organize pedagogical conferences in the country. ${ }^{491} \mathrm{He}$ hoped these conferences would help teachers learn about new teaching methods and how to put them into practice given the lack of normal schools Peru. He emphasized conferences should not be reduced to reading a paper and urged that they incorporate specific lessons and open discussion of pedagogy while also allowing space for dissertations and debates about systems, methods, programs, textbooks and other subjects related to the organization of schools. Instead of accepting modern pedagogical

\footnotetext{
${ }^{489}$ See "Sección Nacional" where numerous teachers respond to the request to contribute to the periodical in El Faro, November 1, 1889. Also see "El Faro," El Faro, November 16, 1889

490 “Una palabra de agradecimiento al supremo gobierno," La Instrucción (Lima), November 25, 1889.

491 “Conferencia pedagógicas,” La Instrucción, November 25, 1889.
} 
precepts and implementing them without criticism, Guzmán hoped these subjects would be discussed and debated to find the best ways to adapt them to Peruvian schools.

A soft rebuttal to Guzmán's article and the latter's response revealed that Guzmán also sought to pressure the central government into taking a more active role in organizing the conferences. Responding to Guzmán's article, educator and former school inspector Pedro M. Rodríguez wrote that the provincial council had established pedagogical conferences in the mist of the War of the Pacific in 1879 and 1881. Moreover, Rodríguez noted that these conferences yielded important results including a series of regulations for Lima's schools. Rodríguez made a call to the current school inspector and Lima's mayor (alcalde) to reinstitute the conferences. ${ }^{492}$ Although Guzmán agreed with Rodríguez that Lima's provincial council had organized productive conferences, he noted that the efforts lacked regularity. In his response, Guzmán also emphasized that organizing the conferences should be a responsibility of the Consejo Superior de Instrucción Pública and should not be a task left to the initiative of provincial councils. ${ }^{493}$

Guzmán's call to organize more public debates surrounding matters of education was itself a reflection of an expanding and diversifying "public sphere" of pedagogical society, a space through which educators and writers sought to modernize methods used in schools. Pedagogical society encompassed several associations dedicated to public education, most of which appeared shortly before and in the aftermath of the War of the Pacific. For instance, the association Colaboradores de la Instrucción operated in Lima

\footnotetext{
492 “Conferencias pedagógicas,” La Instrucción, December 10, 1889.

${ }^{493}$ Ibid.
} 
during the 1870s. The ones created after the war included the Sociedad de Preceptores, founded on April 3, 1885; the Sociedad de Instrucción Primaria, established in 1885; and the Sociedad de Instrucción Popular, established around 1890. When compared with earlier associations, those that appeared in the last decades of the nineteenth century had a more diverse membership. ${ }^{494}$ The president of the Sociedad de Instrucción Popular, liberal lawyer Jose B. de Ugarte argued that his association was constituted by "common men" (hombres del pueblo). ${ }^{495}$ Although only men appeared as members of the association Colaboradores de la Instrucción, women made up more than half of the members of the Sociedad de Preceptores at its foundation. ${ }^{496}$

Critical debate constituted a central tenet of these new associations. The Sociedad de Preceptores added to its 1885 Reglamento a provision to hold its own monthly conferences and the Sociedad de Instrucción Primaria had a similar provision. ${ }^{497}$ Lima's town council passed a school code, which ordered the organization of pedagogical conferences as well. The conferences needed to take place monthly and include a practical lesson for students about any of the subjects in the official curriculum and the reading of a lesson on pedagogical matters. These conferences would be presented by alternating

\footnotetext{
${ }^{494}$ For example, in 1822, San Martín ordered the formation of the Sociedad Patriótica of Lima and charged it with spreading the Lancasterian method in Peru. San Martín chose the forty "perpetual" members, which were all men and part of Lima's elite. See "Erigiendo la Sociedad Patriótica de Lima," in Oviedo, Colección de Leyes, 82.

495 “Sociedad de Preceptores," El Faro, July 16, 1891. Also see "Discurso pronunciado por el Presidente de la Comisión de la 'Sociedad de Instrucción Popular,' doctor don José B. Ugarte in El Faro, July 16, 1890.

${ }^{496}$ See "Colaboradores de la Instrucción in Almanaque del Comercio de Lima 1876 (Lima: Imprenta del Estado, 1876), 234 and "Socios fundadores" in Reglamento de La Sociedad de Preceptores (Lima: Imprenta de J. Francisco Solis, 1885), 18.

${ }^{497}$ See Reglamento de la Sociedad de Preceptores (Lima: Imprenta de J. Francisco Solis, 1885); "Sociedad de Preceptores," El Faro (Lima), July 16, 1891 and "Sociedad de Instrucción Primaria," El Faro, June 16, 1891.
} 
teachers and their auxiliaries. Their subject matter needed to be advertised well in advance.

Two additional conferences needed to be held by private school teachers. ${ }^{498}$ Participants in pedagogical conferences addressed a variety of topics including teacher aptitude, school buildings and supplies, student registration in individual school districts, and programs for supplying poor children with clothing and shoes. Student attendance and ways of improving it was also an important focus, particularly the effect of fines and awards for those heads of household responsible for sending their children and their servants to school. $^{499}$

Several institutions, associations and teachers organized conferences, ensuring they did not remain unfulfilled plans. The Sociedad de Preceptores combined prizegiving to students and teachers with monthly pedagogical conferences. ${ }^{500}$ Educator and textbook writer Serafin Filomeno held several conferences where he addressed various pedagogical subjects between April and May of 1890, and actively organized conferences in $1892 .{ }^{501}$ The Liceo Fanning, under the direction of educator Elvira García y García, advertised that its students held "public conferences" each month. ${ }^{502}$ These conferences differed in frequency and content from public examinations (certámenes públicos), which evaluated

\footnotetext{
${ }^{498}$ El Faro (Lima), December 16, 1889. Also see "Reglamento puesto provisionalmente en vigencia por acuerdo de la Junta Directiva de 11 de Septiembre de 1888," in Pedro de Osma, Leyes, Resoluciones y Ordenanzas relativas al H. Concejo Provincial de Lima (Lima: Imp. de "El Comercio," 1893).

499 “Crónica Nacional,” La Escuela Peruana, December 1, 1892.

500 “Sociedad de Preceptores,” El Comercio, September 11, 1888.

501 "Conferencias de Pedagogía Práctica," El Faro, April 1, 1890 and El Faro, May 1, 1890. Also see "Conferencias pedagógicas," La Escuela Peruana, June 1, 1892.

502 “Liceo Fanning” in El Comercio, May 6, 1895.
} 
the performance of teachers (and later, students) and were only held once or twice per year. $^{503}$

Essay contests also provided an opportunity for teachers across Lima and Peru to participate in the national conversation about education, particularly on the question of how to spread alphabetic literacy and primary instruction more efficiently among adults and non-Spanish speakers. On its issue of December 25, 1889, Guzmán summoned readers of La Instrucción to contribute to lifting the "national edifice" by participating in the newspaper's essay contest. ${ }^{504}$ The first question asked respondents to come up with processes to facilitate the dissemination of primary instruction in the interior of Peru where Spanish was not spoken. A second question asked about the utility (conveniencia) of establishing schools for adults and the primary benefits of their organization. A third section asked for respondents to send an object lesson on the "Graduated Numbering System." The author of this work would later develop the subject in order to incorporate it as a practical lesson that would serve as the basis for a future pedagogical conference. All winners would receive books as prizes. The winner of the first would get a copy of $L a$ educación intelectual y los métodos de enseñanza (1886), which was part of the pedagogical encyclopedia of Pedro García de Alcántara. The winner of the second response would obtain four volumes from the second serialized collection of the Biblioteca del

\footnotetext{
${ }^{503}$ On the tranformation of these examinations over the course of the nineteenth century, see Eugenia Roldan Vera, "La escuela mexicana decimonónica como iniciación ceremonial a la ciudadanía: normas, catecismo y exámenes públicos," in Ciudadanos Inesperados: Espacios de formacion de la ciudadanía ayer y hoy, ed. Ariadna Acebedo rodrigo et. al (Mexico D.F.: El Colegio de México, 2012), 39-69.

504 “Certamen Pedagógico,” La Instrucción, December 25, 1889.
} 
Maestro published at the time in Barcelona. The winner of the last question would get the volume Una lección de Higiene (1889) by Dr. J. A. Berra of Montevideo.

The essay response of Manuel J. Alba, published the following August in La Instrucción, illustrated educators' emphasis on finding solutions to the problem of alphabetic illiteracy through an examination of specific conditions in Peru. ${ }^{505}$ Alba began his essay by outlining that the use of Quechua by a large portion of the Indian population in Peru posed significant problems for the spread of primary instruction, however, his solution was not to eradicate the language. On the contrary, he believed the Andean language could overtake all others as a direct result of using Quechua alongside modern pedagogical methods to spread primary instruction. The intuitive method constituted an essential component of Alba's plan because teachers would be educating students whose primary language was Quechua or another Andean dialect, but who also had varying degrees of understanding of the Spanish language. Using this method offered teachers latitude in adjusting their lessons and "pedagogical procedures" accordingly. Alba also made some practical recommendations regarding the construction and location of new school buildings and the use of financial resources from municipalities, private persons and central government for providing the poor with school supplies. ${ }^{506} \mathrm{He}$ proposed that congress pass a law requiring the central state to subsidize the costs of municipalities. For

\footnotetext{
${ }^{505}$ Manuel J. Alba, "Procedimientos que deben emplearse para conseguir la difusión de la primera enseñanza en los lugares del interior del Perú, donde no se habla la lengua castellana," La Instrucción, August 25, 1890 .

${ }^{506}$ Manuel J. Alba, "Procedimientos que deben emplearse para conseguir la difusión de la primera enseñanza en los lugares del interior del Perú, donde no se habla la lengua castellana," La Instrucción, September, 10, 1890.
} 
an effective execution of his proposed measures, Alba insisted on the necessity of conducting meticulous examination of local conditions, including the needs, resources, languages and customs of various regions.

For Alba, the task of uniting a political territory under one language - in Peru's case, under Spanish or Quechua — had precedent in world history and more importantly, in national history (historia patria). Alba argued that one of the "Peruvian monarchs" offered a salient example for such a colossal undertaking. He likely referenced the Inca ruler Pachacuti who helped expand the empire during the fifteenth century and who, with the help of civilizing emissaries (mitmaqs), made Quechua the official language of the state. ${ }^{507}$ He stressed that the imperial court, its subjects, and conquered peoples adopted Quechua without detriment to other spoken languages. Moreover, he argued that history could illustrate the means that offered practical results, notwithstanding that Incas ruled during a period of ignorance (oscurantismo) and regression (atraso) relative to the contemporary epoch in which "elements of progress honor our century." 508 Alba's response embodies the tensions at the center of late nineteenth-century pedagogical project. An appropriation of the Inca past as national history and admiration for the efficient administration of vast territories and diverse peoples mixed with disdain for a period that lacked the markers of European modernity.

Based on its print run, the most successful of the pedagogical newspapers that appeared in the last two decades of the nineteenth century became La Escuela Peruana,

\footnotetext{
${ }^{507}$ Ibid. Inca rulers sent the mitmaq to newly conquered lands to teach religion and Quechua, see Rolena Adorno, The Polemics of Possession in Spanish American Narrative (Yale University Press, 2007), 44. ${ }^{508}$ Ibid.
} 
published between 1892 and 1911. The periodical was directed by Professor of Sciences Manuel Octavio Suarez and Professor of Literature Armando Filomeno, although Guzmán y Valle replaced Suarez when he became ill in June of $1895 .{ }^{509}$ The first issue appeared in April of 1892 with bookseller Juan Galland also as editor during the first months and shortly before he died. ${ }^{510}$ In its first issue, the editors of La Escuela Peruana noted they sought to modernize Peruvian education through the propagation of educational methods that could be adapted to the Peruvian context. Particularly, they hoped to influence classroom time management in primary schools, distribute communications regarding official curricula and educational programs, discuss school materials and furniture, promote updated disciplinary methods, and edit pedagogical manuals and new texts appropriate for Peruvian schools. The first issue also noted that teachers could request information from the editorial department and publicly address their concerns to the authorities through the newspaper. ${ }^{511}$

In 1895, La Escuela Peruana published a proposal for the regulation of textbooks, which its author hoped to implement through the Consejo Superior de Instrucción Pública. ${ }^{512}$ Doctor Pedro A. Labarthe argued that it was necessary to determine a set of prerequisites before government bodies continued to approve school textbooks. Article one proposed that the examination of all works presented to the Consejo Superior should be based on five factors including textbook content, methods, format, exemplification, and

\footnotetext{
509 “Aviso," La Escuela Peruana, June 1, 1895 and "Manuel Octavio Suarez," La Escuela Peruana, September 1, 1895.

510 “Rasgos biográficos,” La Escuela Peruana, September 1, 1892.

511 “Nuestro propósito,” La Escuela Peruana, Lima, April 1, 1892.

512 “Libros de texto," La Escuela Peruana, June 1, 1895.
} 
material composition. Article 1 argued that content in books needed to be "truthful" or accurate and "sufficient" so that it fulfilled requirements of the official program. The content also needed to be adequate for the intended audience, which needed to be clearly stated in the front cover. Any doctrines that were not integral to the text but with some explanatory value were to be included in the back of the book. To be approved, religious texts needed to conform to the religion of the state. Texts on grammar needed to conform to the doctrines of the Real Academia de la Lengua. Books about geography and the history of Peru needed to use specific maps approved by the Consejo Superior. The regulations also recommended the use of national motifs particularly for the subjects of reading, moral instruction, geography and the physical and natural sciences. Books that "debilitated" the patriotic spirit or love for republican institutions would not be approved.

The merits and the logical and didactic value of subjects, definitions, divisions, classifications, exemplifications of textbooks would be the responsibility of the Consejo Superior. This government body would be in charge of rejecting all textbooks that used outdated didactic methods that had been "universally condemned" or methods that used spelling (deletreo), syllable (silábico) and phonetic (fónetico) techniques primarily based on memorization. Following the last precept, reading books would be based on the analytical and synthetic method (método analítico-sintético). ${ }^{513}$

\footnotetext{
513 "Curso metódico de lectura y escritura, según el método analítico sintético," La Escuela Peruana, April 1,1892 . With this method, teachers needed to choose a number of words and sounds representative and familiar to children's early language. Following his or her familiarity with whole words, the child needed to begin writing them after a series of preparatory writing exercises. The process of breaking down the word into syllables and then letters followed. Rather than learn letters by their name, which could often confuse the child, the teacher needed to use their phonetic value by first pronouncing the syllable and ultimately isolating the letter. From here, the teacher taught children how to form or synthesize new syllables, words and phrases. During this process, the child also learned how to write the broken down syllables, letters, and new words.
} 
Several articles also addressed the methods used in subjects beyond reading and writing. Textbooks on the physical and natural sciences needed to use the inductive method:

They will begin with observation and then to the principle or definition and from the law or definition to the application of the first or exemplification of the second. Therefore those who purely follow the deductive or synthetic method will not be approved. ${ }^{514}$

Even geometry, grammar and arithmetic textbooks that targeted students in primary schools needed to use the inductive method. The proposal rejected the catechistic format arguing that textbooks needed to use an expositive format. In addition to the correction, clarity and precision of the language, evaluators would also examine whether the orthography followed guidelines of the Real Academia Española. Books needed to use the decimal metric system for all weights and measures and the national currency for all prices. Wherever it was necessary to determine pesos, measures or foreign coins, the equivalents in the metric system or national currency needed to be expressed in parenthesis.

The proposal also demanded certain standards for the material composition of textbooks. The paper and type of letter would be determined by the Academia Nacional de Medicina. The index of the materials needed to indicate the program of the course. Grammatical texts would contain excerpts for "gradual analysis" at the end of the primary content. Literary textbooks limited excerpts of compositions to 100 lines. The same books needed to include a list of notable works for each literary genre. Geography and history books without corresponding atlases needed to recommend one for the course. History

\footnotetext{
514 "Libros de texto," La Escuela Peruana, June 1, 1895. Original text: "partirán de la observación á la ley ó la definición y de la ley ó definición á la aplicación de la primera ó ejemplificación de la segunda. Por lo tanto no serán aprobados los que puramente sigan el método deductivo ó sintético."
} 
textbooks needed to include simple sinoptic charts with the most notable events according to dates. Math books required at the end a sample of problems that were gradual and related to the subject at hand. Subjects such as physics, chemistry, cosmography and natural history required illustrations that were clear, indispensable and characteristic of the subject. Texts on morality required abundant examples that utilized practical situations, preferably taken from national history.

La Escuela Peruana enabled open and critical discussion of educational legislation in other key areas. Primary school teachers Juana B. Pinto and Ramón Jiménez Pimentel sent the periodical the observations on the current school codes. ${ }^{515}$ After the 1876 school code was passed, two additional laws were passed in 1884 and 1886. An 1888 law had dictated that the 1876 and 1886 school codes were to be implemented simultaneously. Pinto and Pimentel noted that the 1886 law failed to include the study of Peruvian history in the curriculum. The law also divided primary education into three grades and prescribed for the second and third grades to be taught in only one year. They believed that teaching the material of these two grades in only one year was impossible and noted that to avoid problems with these laws they had decided to use the "plan de estudios" included in the 1876 school code. They further objected to the current prescription that different subjects be taught in different years. They argued that modern methods prescribed for subjects to be taught through the cyclical or concentric method. In other words, when the child entered the school system, he needed to be introduced to all primary school subjects in a gradual manner. In the second and third grade, the same subjects needed to be taught with

\footnotetext{
515 "Plan de estudios de las escuelas municipales del Callao," La Escuela Peruana, June 1, 1895.
} 
increasing complexity and importantly, according to the ability and evolution of students. ${ }^{516}$ They argued for the importance of communicating these ideas to all school teachers, they would eventually teach, talking at first about everything without addressing every aspect of the subject. ${ }^{517}$ Since this method could lead to the mental exhaustion of the child, Pinto and Pimentel cautioned that teachers also needed to keep in mind some of Comenius's ideas for teaching, which needed to follow a "natural" slow progression without skipping over important concepts. Modern methods, however, needed to accommodate for realities in Peruvian schools. Teachers needed to adjust the methods depending on local conditions, number of sections, auxiliaries, students and their own achievements. They ended with the recommendation that limited classes to 20 minutes for preschool children (parvulos), 30 minutes for students in first grade and 45 minutes for students of second and third grade. Finally, they reminded that teachers should do away with methods that abused memorization and lecturing and that intellectual exercises needed to be alternated with rest, recreational time and physical exercise.

With the emergence of Lima's pedagogical public sphere, book competitions garnered a much larger participation than that of the events organized under the Civilista leadership in the 1870s. This participation was enabled by a growing number of Peruvian

\footnotetext{
${ }^{516}$ Ibid, original text: "Partiendo pues de un centro común, y principiando en diminutas proporciones, los conocimientos, con ser los mismos, van cada año aumentando en riqueza de pormenores y dilatándose cada vez más, á la misma manera que se dilatan los círculos concéntricos que forma una piedra al caer en una agua tranquila."

${ }^{517}$ Ibid, original text: "hablar desde el principio de todo sin agotar nunca ni con mucho toda la materia: de todo un poco."
} 
educators who wrote their own textbooks. ${ }^{518}$ These contests pitted national authors against foreign writers, but dozens of awards went to Peruvian authors, booksellers, teachers, and merchants of school supplies. The awardees made use of their public distinctions by mentioning them in advertisements of their works, schools, and bookstores. These contests also provided a platform for the exhibition of national history, geography, and culture, where organizers and participants collaborated with officials in promoting Peruvian nationalism and industry.

In 1888, the Ateneo de Lima along with the Honorable Concejo Municipal de Lima announced the first "Certamen de Textos y Exposición Escolar" in several of the city's periodicals. The association had recently changed its name from Club Literario to Ateneo de Lima. The Club Literario was founded during the 1870s by lawyer Francisco García Calderón and several members of Lima's elite. During those years, the Club mainly organized literary gatherings where members discussed their civic and democratic interpretation of Peruvian culture. ${ }^{519}$ During its reorganization between 1886 and 1887, the association began to focus more closely on pedagogical matters and on its new homonymous periodical. ${ }^{520}$ In October of 1888, the Ateneo invited authors, editors, and school supply merchants to participate in the contest, which would take place the following

\footnotetext{
${ }^{518}$ See Ateneo de Lima, Certamen de Textos y Exposición Escolar: Distribución de premios y clausura Septiembre 8 de 1889 (Lima: Imprenta y Librerias de Benito Gil, 1889), 21-31 and "Exposición de 1892," La Escuela Peruana, January 1, 1893.

${ }^{519}$ Carlos A. Forment discusses the early years of the Club Literario, but does not follow its transformation after the War of the Pacific, see Democracy in Latin America, 1760-1900 (Chicago and London: The University of Chicago Press, 2003), 311.

${ }^{520}$ On the reorganization into the Ateneo de Lima, see "El Ateneo," in Museo de historia nacional (Lima: Imprenta La Industria, 1906), 23 and Ateneo de Lima, Certamen de Textos y Exposición Escolar: Inauguración Jueves 15 de Agosto de 1889 (Lima: Imprenta de la Merced, 1889), 10.
} 
year. ${ }^{521}$ The call emphasized the contest's focus on primary education and preference for elementary textbooks. Each textbook needed to express its grade level in order to participate. The textbooks needed to be submitted by June 1, 1889, either in printed or handwritten form. According to the rules, the Ateneo promised to come to an agreement (se pondrá de acuerdo) with the participants that obtain first places in each subject in order to have the Concejo Superior declare their work as "obligatory and authorized." The books would be judged on their accuracy, editorial work, material composition, and price.

The contest judged dozens of books, many of them written by Peruvian authors. The first section encompassed textbooks that targeted education within the family (enseñanza de la familia). They included alphabet books, reading books (cartillas), prints (estampas), books with educational games, and books with simple and moralistic stories. The second section involved more advanced reading books for schools with literary compositions, excerpts for reading out loud, elementary encyclopedias, and object lessons. Another category combined more advanced textbooks on religion, arithmetic, Spanish grammar, universal geography, universal history, Peruvian geography, and Peruvian history. A fourth section focused on methods for teaching physical education, hygiene, urbanity, drawing and music. An unspecified number of gold medals would be available for the first section, four for the second, four for the third and two for the last. Secondary awards including silver medals of first and second class, and a bronze medal would also be available in these categories. Each section would have a committee composed of three members, with one requiring a university degree and position as a professor. During the

\footnotetext{
${ }^{521}$ Ateneo de Lima, Certamen de Textos y Exposición Escolar: Inauguración Jueves 15 de Agosto de 1889, 5 and "Certámen," Boletín Bibliográfico, December 1, 1888.
} 
ceremony, the Ateneo promised to exhibit school supplies and instruments of instruction that were manufactured in Peru or abroad. It committed to pay for the transportation of the materials to the capital, but each exhibiting party was responsible to name a person in charge of arrangement and presenting any pertinent explanations of the objects.

Forty-two out of the eighty-three awardees who received medals for their textbooks were educators from Peru, among them Edelmira Patiño and Teresa González de Fanning for the textbook Lecturas infantiles and the manuscript "Enciclopedia infantil," respectively. ${ }^{522}$ Educators Enriqueta Lund and Matilde A. de Brenner received medals for their expositions of school materials and student handcrafts, needlework and embroidery. Lund's exhibition included handiwork based on Friedrich Froebel's system of education for preschoolers, while De Brenner's exhibition had materials for teaching minerology, physics, chemistry and a section on photography. Other exponents included the municipalities of Lima and Callao, the Colegio Peruano from teacher Agustín Whilar, the Liceo Preparatorio of Jose F. Maticorena and Agustín García Godos as well as the Sociedad de Preceptores and its night and Sunday schools. Several of the teachers and directors exhibited part of their school libraries.

Teachers from the interior of Peru who won sections of the contest gained the opportunity to access better printing houses in Lima. Third grade teacher from Cajamarca Juan C. Verjel had submitted his geography textbook Lecciones intuitivas de Geografía sobre el Mapa-Mundi in an edition of poor quality. ${ }^{523}$ This edition was printed in his native

\footnotetext{
522 Ateneo de Lima, Certamen de Textos y Exposición Escolar Distribución de Premios y Clausura (Lima: Imprenta y librerías de Benito Gil, 1889), 21-31.

523 “Lecciones intuitivas de Geografía sobre el Mapamundi," La Instrucción, March 25, 1890.
} 
Cajamarca by the Imprenta del Ferrocarril the same year of the book contest, in 1889. Only a few years later, the book would have eleven editions. One edition published in the late 1890s included numerous illustrations and was published by E. Rosay, formerly the the Librería Francesa Cientifica Galland. Its first pages published the reviews of the Boletin Bibliográfico and La Instrucción, which commented on the merits of the elementary book in the teaching of geography using the intuitive method. ${ }^{524}$ Prince noted that the first edition was sold immediately and various teachers and directors were already using it. $L a$ Instrucción noted that it won an award in the textbook contest and recommended for the youngest students. ${ }^{525}$

\section{Conclusion}

This chapter traced the growth of Lima's pedagogical public sphere. By the end of the nineteenth century, Lima's public sphere had new spaces where teachers, booksellers and enthusiasts of education found a niche to promote a wide range of educational endeavors. New pedagogical newspapers helped promote educational congresses, intellectual contests, and national exhibitions that were often combined with civic festivities. Existing civic events were modified and new ones were organized. The central government as well as municipal and provincial administrations were variously involved in these events. The public display of awards and recognition set forth examples of extraordinary citizenship for the rest of the populace. While these spaces received the support of the Peruvian state and local government, they still promoted critical debate about

\footnotetext{
524 “Geografía sobre el Mapamundi,” Boletín Bibliográfico, March 1, 1890.

525 “Lecciones intuitivas de Geografía sobre el Mapamundi," La Instrucción, March 25, 1890.
} 
pressing educational matters. At the same time, a broad range of participants including booksellers, teachers, and textbook authors gained the cultural capital to help them in their own private endeavors. For teachers influenced by modern pedagogical methods, these events functioned as auxiliary educational institutions to schools. 


\section{CONCLUSION}

This dissertation entered the physical spaces where nineteenth-century limeños obtained their reading materials, from the early bookstores and republican schools that offered imported European literature, to the national library with its less populated reading hall, to the bookstore-publishing houses where owners spearheaded efforts to create a national book and textbook industry, to the various public venues where both the state and private actors sought to legitimize and homogenize reading material.

It made two overarching theses. First, "Reading Spaces" argued that until the middle of the nineteenth century, reading practices continued to center on a broad range of European materials published abroad or copied and sold in Lima's bustling market of "simplified enlightenment." This Eurocentric culture circumscribed the reading practices

of both liberals and conservatives. Some conservatives rejected the new European pedagogies, but in doing so, they also emphasized the effectiveness of traditional European texts. Peruvians who were educated in Europe often returned and propagated European pedagogies and textbooks through their own translations, contributing to the dissemination of European texts as well.

Although changing eighteenth-century notions about education and the uses of alphabetic literacy influenced educational legislation after independence, prompting the republican government to promote democratic models of reading, the state was generally unable to produce the educational literature demanded by limeños. The incipient local press mostly focused on publishing newspapers. The result was that during the first half of the nineteenth century, less than 5 percent of the literature produced in Lima could be 
categorized as educational. Teachers and parents thus turned to imported texts, which could be found widely according to contemporary accounts and bookstore advertisements. This meant that the most impressionable readers - children and adolescents—-were generally exposed to learning through European texts, whether copied, translated, compiled, or read out loud in a classroom.

Reading culture during this period reflected other continuities with the colonial period, particularly in the national library which, despite official characterizations of the institution as democratic and inclusive, remained a center of study for a small number of learned men. Chapter two presented a history of Lima's public library, which more than any other component of the republican project, symbolized the state's commitment to democratizing reading practices and spreading enlightenment. It uncovered the contradictory functions outlined for Lima's public library by its founders and administrators, as well as the everyday realities that shaped the experiences of library users. For much of the nineteenth century, elites' own limited visions for the institution, political instability, insufficient funding, and understaffing limited the library's functionality for diverse groups. As Lima's literacy rates increased at the end of the nineteenth century and more visitors began to use the services of the institution, administrative sources revealed the tensions between elitist and democratic models of reading.

The mid-nineteenth century was a period of educational renewal. Liberals passed educational legislation, which promoted curricular diversity in schools. In the private sphere, bookstores proliferated and initially supplied a wide range of European literature. The profits from this lucrative book market, however, enabled many booksellers to engage in publishing activities. They turned to Peruvian teachers and educators who readily wrote 
and published their texts, providing the government with some of the first national textbooks.

The second thesis centered on the significance of the development of Lima's publishing industry and the availability of national reading material for state and nation formation processes. The mere volume of new educational reading material prompted textbook standardization, as chapters 3 and 4 showed. Importantly, these texts created a national textbook industry. Peruvian teachers no longer had to use the translated, copied or abridged copies of European educational texts. Reading content for children was imbued with all-things-Peruvian, particularly in the subjects of history, geography, and civics, but also in reading books. The nineteenth-century Peruvian state thus coopted the disjointed efforts of a broad range of enthusiasts of education rather than create a national textbook industry, which is often associated with the rise of the twentieth-century Teaching State.

The proliferation of popular book collections also demonstrates an expansion and diversification of reading culture in Lima. These collections published popular songs, Peruvian or "criollo" cooking recipes, and advice and useful "tips." Editors and booksellers advertised the content as "Peruvian" or "national" traditions and modes of behavior, often extolling popular culture. These books, however, also reified regional differences by contrasting and essentializing the urban population with a "criollo" and European coastal identity against a highland—and mostly Indian—population.

The second half of the nineteenth century also saw the proliferation of pedagogical newspapers, which promoted communication among a broad range of "enthusiasts of education." They influenced various aspects of educational legislation and school culture. The byproduct of the proliferation of pedagogical newspapers and associations became the 
expansion of Lima's "public sphere." Educators organized pedagogical conferences, intellectual competitions, national expositions and reorganized civic festivities. The integration of activities involving public recognition of professional merit and civic festivities, as well as their tangible awards and prizes materialized official nationalist discourses that modeled ideal hardworking citizens in service of the nation.

The changing educational landscape fueled the anxieties of some contemporary observers like sociologist Joaquín Capelo and mayor Federico Elguera. Both rejected Lima's reading culture and the new curricula instituted in the capital's schools, which required the introduction of textbooks about history, grammar, geography, arithmetic, the metric system, Peruvian geography and history, drawing and pedagogy. They believed these subjects were superfluous for most of the Peruvian population and neglected the physical development of children, which was required for practical labor. In their view, this neglect ultimately risked the prosperity of the nation since they saw labor capacity as one of Peru's most important resources. Elguera thus prescribed a curriculum that protected physical development and introduced "moral and temperate habits" while it formed men who knew "how to read, write, count and handle the pick, the trowel and the handsaw. ${ }^{.526}$ At the dawn of the twentieth century, the elite model of reading resurfaced with vociferous advocates.

Often, nineteenth-century studies place Liberals and Conservatives at odds, with the first adhering to a Europeanized and secular model of education, and the second to

\footnotetext{
${ }^{526}$ Federico Elguera is quoted in Joaquín Capelo's Sociologia de Lima, 93. Origicanl text: "Debemos dedicarnos de preferencia á protejer el desarrollo físico é introducer hábitos de moralidad y temperancia y hacer hombres que sepan leer, escribir y contar, y manejar el pico y el badilejo y el serrucho."
} 
more traditional forms of education involving extensive Church control, and moral and religious instruction. While this dichotomy certainly shaped debates in the early republic, by the second half of the nineteenth century, educators appeared more concerned with institutionalizing the hallmarks of pedagogical modernity by developing a textbook industry with national content, implementing curricula with diverse subjects and reading materials, and promoting the use of the intuitive method in classrooms. The success of educators is evident in the growth of Lima's literacy rates and the pervasiveness of reading culture by the early twentieth century. The comments of Joaquín Capelo and mayor Federico Elguera point to a continued tension among elites over the functions of reading into the twentieth century. 


\section{REFERENCES}

\section{PRIMARY SOURCES}

\section{NEWSPAPERS}

Boletín Bibliográfico

Comercio, El

Educador Popular, El

Escuela Peruana, La

Faro, El

Gaceta del Gobierno

Gazeta del gobierno de Lima Independiente

Instrucción, La

Peruano, El

\section{PUBLISHED DOCUMENTS, BOOKS AND TEXTBOOKS}

Astete, Gaspar. Catecismo de la Doctrina Cristiana. Ayacucho: Imprenta de "El Progreso" 1884.

Bedoya, Eusebio de. Nuevo curso de idioma francés: según el sistema de Robertson para el uso de las casas de educación. Huancayo: Imprenta del Colejio, 1856-58.

Benites, Enrique. Compendio de geografía Moderna Universal para las Escuelas de Instrucción Primaria de Tercer Grado. Lima: Benito Gil, Librería Universal, 1885.

Beraun, Mariano D. Ensayo sobre la trisección del Angulo. Lima: Tipografía del "Comercio 1861.

Bolognesi, Mariano Explicaciones provisionales sobre la enseñanza colectiva con el nuevo método de lectura dedicado a las madres de familia por el Crel, $M$. Bolognesi. Lima: Imprenta de la Escuela de Ingenieros, 1892.

Bosio, Luis, Catecismo Constitucional Peruano (Educación Popular Biblioteca del Pueblo Libro IV.) (obsequio al pueblo 28 de julio de 1892). Callao: Imprenta del Muelle Darsena y Malecón, 1892. 
Cabrera, Bernabé. Ejercicios prácticos de teneduría de libros por partida doble para aprender sin necesidad de maestro a llevar los libros de una casa comercial. Lima: J. Galland, Editor Librería Francesa Científica, 1892.

Carbo, Pedro Memoria sobre las bibliotecas públicas populares, circulantes y escolares de Europa y América. Guayaquil: Imprenta de "El Telégrafo," 1887.

Carrasco, Eduardo. Calendario y Guía de Forasteros de la Republica Peruana para el año 1852. Lima: Imprenta de Félix Moreno, 1852.

Casos, Fernando Barbe. La filosofía del profesor E. Barbe, de la escuela francesa. Curso elemental de psicología, lógica, teodicea, moral e historia de la filosofía. Lima: Editor Benito Gil, 1877.

Cateriano, M. A. El Ayo del Libertador del medio día de América ante la sociedad actual: Trabajo dedicado a la juventud. Arequipa: Tip. Cáceres, 1890.

Chiarolanza, Aníbal. Catecismo civil de los deberes y derechos del hombre y del ciudadano. Lima : Imprenta del Universo, de Carlos Prince, Escuela Industrial de San Pedro, 1874.

Damprun, Antonio. Catecismo o breve explicación de la doctrina cristiana. Lima: Benito Gil, 1884.

Compendio de Historia Sagrada para el uso de los colegios de los sagrados corazones. Lima: Imp. De "El Grano de Arena", 1879.

De la Lama, Miguel Antonio. Catón Cívico. Lima: Imprenta y Librerías, 1889.

De la Lama, Miguel Antonio. Manual del escribano publico peruano. Lima: Imprenta dirigida por Jose M. Noriega, 1867.

De la Rama, Miguel Antonio. La constitución del Perú con sus reformas hasta 1897 explicada y anotada para las escuelas y colegios. Lima: Imprenta Ledesma, 1897.

Del Rio, Patricio. Rudimentos de Aritmética para uso de los alumnos de instrucción primaria de primer grado por Patricio M. del Rio. Lima: Imp. Del Teatro, 1885.

Echenique, Jose Maria. Compendio de la Aritmética para la instrucción de la juventud. Piura Manuscript, 1841.

El Perú y la influencia europea. Paris: Libreara Universal,1862. 
Enríquez, Luis E. La novia del colegial zarzuela en tre actos y en verso. Lima: Imprenta del Universo, de Carlos Prince, 1887.

Estorch, Miguel. Lecciones de Pedagogía dedicada a los seminaristas de la Escuela Normal Central del Perú extractada de los mejores autores. Lima: Carlos Prince, 1887.

F.V.D. Compendio de Historia sagrada para uso de las casas de educación. Imprenta del "instituto Científico," 1894.

Fanning, Teresa. Lecciones de Economía Doméstica. Lima: Imprenta y Librería de San Pedro, 1893.

Fanning, Teresa. Lecciones de Geografía Universal. Lima: Imprenta y Librería de San Pedro, 1897.

Fanning, Teresa. Lecciones de historia santa. Lima: Imprenta y Librería de San Pedro, 1894.

Filomeno, Serafín. Cartilla Pedagógica sobre los principios generales de educación y el modo practico de ensenar los diferentes ramos de instrucción primaria. Lima: Viuda de J. Galland, 1893.

Fuentes, Manuel Atanasio. Catecismo de Economía Política. Lima: Imprenta del Estado, 1876.

. Estadística General de Lima. Lima: Tipografía Nacional de M. N.

Corpancho, 1858.

- Guía histórico-descriptiva administrativa, judicial y de domicilio de Lima. Lima: Librería Central, 1860.

Gamarra, Abelardo. Reglas para escribir cartas. Lima: J. Galland. Librería Francesa Científica, 1889.

Garcia Godos, Artidoro. Compendio de Aritmética Practica Conforme al Programa Oficial para uso de los alumnos de Instrucción Primaria de Primer y Segundo Grado. Lima: Imprenta, Librería y Encuadernación Gil Banco del Herrador, 1896.

Garcia, Jose Antonio. Curso Teórico-Práctico Comercial Distribuido en 12lecciones. Teneduría de libros el poderla aprender sin maestro. Lima: Imprenta de Jose, 1848.

Gaume, Jean Joseph. Compendio Abreviado del Catecismo de Perseverancia para el uso de los niños . Lima: Librería Universal, 1868. 
González, Vigil. Manual de Derecho Público-Eclesiástico Para El uso de la Juventud Americana. Lima: Imp. Del "Pueblo" por M. A. Reyes, 1863.

Gordillo, Martin. Libro Cuarto de Ortología práctica. Callao: Imprenta de Mariano Gómez Y Ca, 1868.

Gavin, Juan B. Aritmética Practica, razonada y manual para el comercio al alcance de todas las inteligencias. Lima: Imprenta de "La Patria", 1874.

Granda, Jose. Aritmética Practica dedicado a los alumnos de las escuelas de Instrucción Primaria de segundo grado y a los alumnos del primer año de Instrucción media. Lima: Librería Clásica y científica, 1878.

Hidalgo, Lorenzo. Nociones de Higiene y Gimnasia. Arequipa: Imprenta de Francisco Ibáñez, 1883.

Jeckel, Bernardo Maria. Gran Galería de Pinturas Antiguas. Lima: Imprenta del Universo de Carlos Prince, 1899.

Junta de Beneficencia. Catecismo de Urbanidad presentado por la Junta de Beneficencia de la Ciudad del Cuzco para la enseñanza de las escuelas de instrucción primaria de niñas del departamento. Cuzco: Imprenta Libre, 1850.

La Guerra del Pacifico. Lima: Imprenta del universo de Prince y Buxo Calle de la Veracruz, 1880.

La-Rosa Toro, Agustín. Física o Estudio de las Propiedades generales de los cuerpos con aplicaciones a la agricultura y otras industrias dedicada a los alumnos de los colegios de instrucción primaria en el Perú. Lima: Imprenta dirigida por J. R. Montemayor, 1866.

Lastarria, J.V. El libro de oro de las escuelas. Lima : Imprenta del "Comercio" por J. M. Monterola, 1863.

Leguía, German y Martinez. Nociones de Ortografía Castellana adaptadas al método novísimo. Lima: J. Galland Librería Francesa Científica, 1892.

Lorente, Sebastián. Catecismo de Higiene para las escuelas de instrucción primaria. Lima: Aubert y Loiseau Librerías General y Central, 1867.

Lorente, Sebastián. Catecismo de Economía. Lima: 1867.

Manual del demócrata peruano y conducta del hombre de bien. Lima: Imprenta de El Pais, 1897. 
Manual para ejercer devotamente las horas del día y preparación para la oración, según se observa en la venerable orden tercera de N. P. s. Francisco del convento Grande de los doce apóstoles . Lima: Imprenta de j. M. Masías, 1856.

Manual para el método de ensenar la costura en las escuelas lancasterianas. Lima: Imprenta de la instrucción primaria por juan rosa, 1827.

Manual por el método Lancaster para la Instrucción Primaria. Huaraz: Imprenta del Colejio de la Libertad, 1848.

Márquez, J. A.I. El Alfabeto II. Silabas y Palabras (Serie de Instrucción Primaria). Lima: Imp. De "El Comercio", 1892.

Márquez, J. A. Manual de la escuela (serie de instrucción primaria) (tomo V). Nueva York: Imprenta I Librería de N. Ponce de León, 1874.

Martinet, J. H. Nota sobre la extracción del jugo de la caña. Lima: Imprenta del Universo de Carlos Prince, 1892.

Maticorena, Jose Francisco. Compendio de Geografía Universal. Lima: Benito Gil-Imprenta y Librerías, 1899.

Matto de Turner, Clorinda. Elementos de Literatura Según el Reglamento de Instrucción Pública para uso del bello sexo por Clorinda Matto de Turner. Arequipa: Imprenta de "La Bolsa", 1884.

Melchor de Jovellanos, Gaspar. "Memoria sobre educación pública ó sea tratado teóricopráctico de enseñanza, con aplicación á las escuelas y colegios de niños" in Obras publicadas e inéditas de D. Gaspar Melchor de Jovellanos, ed. by Cándido Nocedal. Madrid: M. Rivadeneyra, 1858.

Mr. Cardeli, y Madama Gacon-Dufour. Manual completo y guía general de pasteleros, confiteros, destiladores, licoristas y perfumadores. Barcelona: Librería Sauri y Comp, 1832.

Monteagudo, B. Memoria sobre los principios políticos que seguí en la administración del Perú, y acontecimientos posteriores a mi separación. Santiago de Chile: Imprenta Nacional, 1823.

M. R. P. Elias C. Passarell. Catecismo de Controversia para el uso del pueblo. Arequipa: Imp. De S. Agustín. 
Navarrete, Francisco. Catecismo histórico dogmático para el uso de la juventud peruana. Lima: Benito Gil Librería Universal, 1872.

Nuevo Cancionero Popular: Colección de canciones, tristes, yaravíes, etc., No 5. Lima: Librería Francesa y Casa Editora J. Galland, 1897.

Nuevo Manual de la Cocina Peruana por un Limeño Mazamorrero: Contiene 320 preparaciones culinarias, pasteles, confites, dulces, etc. Todo Esencialmente Criollo 60 centavos ejemplar. Lima: Librería Francesa Científica Galland E. Rosay , 1897/1900.

Orellana, Estevan. Instrucción de la lengua latina o arte de adquirirla por la traducción de los autores compuesta para la particular enseñanza de unos niños. Lima: Oficina de los niños cuerpéanos, 1759.

Ortiz de Zevallos, Fausto. Peregrinaciones espirituales. Lima: Imprenta y Librería de San Pedro, 1898.

Osma, Manuel. Curso de Pedagogía. Lima: Imprenta Liberal de "El Correo del Perú", 1877.

Palma, Ricardo. Memoria que presenta el Director de la Biblioteca Nacional, correspondiente al Bienio de Julio de 1888 a 1890. Lima, 1890. . Memoria que presenta el Director de la Biblioteca Nacional correspondiente al Cuatrenio del 28 de Julio de 1884 al 28 de Julio de 1888. Lima: Imp. Masías, Ca., 1888.

Patrón, Simón. Cartilla Agraria. Lima: Imprenta de J. Francisco Solis, 1896.

Paz Soldán, Mariano Felipe. Biblioteca Peruana. Lima: Imprenta Liberal, 1879.

Paz Soldán, Carlos. Cartilla de Telegrafía para el uso de los empleados de la compañía nacional telegráfica. Lima: Imprenta de Aurelio Alfaro y Ca., 1868.

Perez, Esteban P; misionero franciscano. La Ciencia mejor de todas las ciencias o pequeñas meditaciones para hacer la oración mental y conseguir por este medio la eterna salvación. Lima: Imprenta y Librería de San Pedro, 1892.

Prince, Carlos. Mi estancia de medio siglo en Lima. Lima: Impreso en casa del autor, 1913. 
Prince, Carlos. Primeros Ensayos del Arte de la Imprenta. Lima: Impreso en Casa del Autor 75, 1897.

R. P. Mercedario Fray Tomas Cáceres. Lecciones de Moral. Lima: Imprenta, Librería y encuadernación de San Pedro, 1896.

Ramírez, Filiberto. Leyes y resoluciones vigentes en materia de Instrucción expedidas desde 1876. Lima: Imprenta y Litografía de Peter Bacigalupi \& Co., 1891.

Ramírez, Melchor. Aritmética Industrial para los alumnos de la escuela industrial municipal de San Pedro (Primera Parte). Lima: Imprenta del Universo de Carlos Prince, 1873.

Recetas para librarse de las calabazas biblioteca popular. Lima: La imprenta del universe, 1882.

Reyes, J. Adolfo. Manual del apicultor peruano. Lima: Imprenta del Monitor Popular, 1898.

Reyna, Antonio. Manual del ciudadano lector. Lima: Imp. De "El Pais". , 1896.

Riofrio, Miguel. Correcciones de defectos de lenguaje para el uso de las escuelas primarias del Perú. Lima: Imprenta del Universo, de Carlos Prince Situada en la Escuela Municipal de San Pedro, 1874.

Rivera, Pedro. Pedagogía. Lima: Huerta y C. a impresores editores, 1862.

Rodriguez, Pedro Manuel. Nociones generales de la Historia del Perú. Lima: J. Galland Librería Francesa Científica, 1890.

Saenz y Criado, Jose; Gastón Tissandier. Manual de procedimientos útiles recopilados por Gastón Tissandier. Callao: Imp. De "El Porvenir" Constitución, 1889.

Salazar, Francisco J. Las Batallas de Chorrillos y Miraflores y el arte de la Guerra. Lima:

Imprenta del Universo, de Carlos Prince, 1882.

Salazar, Manuel. Gramática Castellana para los colegios de instrucción media. Lima: Benito gil, editor Librería Universal, 1871.

Salazar, Manuel. Historia Eclesiástica para los Colegios de Instrucción Media Conforme al Programa Oficial . Lima: Imprenta y Librería, 1893. 
Saldias, Eulogio S. Enseñanza Cívica (Catecismo del Ciudadano) Instrucción popular. Lima: Librería Francesa Científica y Casa Editora Galland, 1899.

Saldias, Eulogio S. Manual del Marinero. Lima: Imprenta de la Escuela de Ingenieros, 1896.

Seoane, Ventura. Geografía de la historia santa y de la vía dolorosa. Traducida y arreglada, para el uso del "Liceo de Niñas" de Lima por la Señorita Dona Ventura Seoane sub-directora de dicho establecimiento. Lima: Imprenta de "El Comercio" por J. M. Monterola, 1868.

Silva Santisteban, Jose. Primeras Lecciones de Religión. Lima: Benito Gil--Editor Librería Universal , 1874.

Suarez, Jose Bernardo. Guía del preceptor primario I del visitador de escuelas (Argentina, Chile). Santiago: Imprenta de la Unión Americana, 1869.

Suarez, Manuel Octavio. Compendio de Zoología. Lima: Casa Editora de J. Galland, 1893.

Suarez, Manuel Octavio. Compendio de Botánica y Mineralogía . Lima: Casa Editora J. Galland, 1893.

Suarez, Manuel Octavio. Compendio de Química para uso de las escuelas primarias de tercer grado. Lima: Casa Editora J. Galland, 1896.

Suarez, Manuel Octavio. Lecciones de higiene privada y escolar para uso de las escuelas primarias de ambos sexos. Lima: J. Galland--Editor Librería Francesa Científica, 1892.

Torres, Jose Luis. Cartilla de Agricultura del Perú. Lima: Imprenta de "El Comercio, 1896.

Torres, José Luis. Catecismo patriótico y los mártires. Lima: Benito Gil, 1893.

Trujillo, Bartolomé. Curso de ciencias naturales destinado a la instrucción primaria superior nociones de historia natural, zoología. Lima: Imprenta de Francisco Solis, 1872.

Trujillo, Bartolomé. Lecciones de moral y urbanidad. Lima: Librería Francesa Científica, 1892.

Única cartilla hispano-americana. Lima: Imprenta del Universo, de Carlos Prince, 1893. 
Valderrama, Jacinto. "Extractado por" Catecismo Patriótico-Político, para el uso de las escuelas de Instrucción Primaria de la Republica. Trujillo: Imp. de "El Porvenir," 1875 .

Valdés, Jose Manuel. Salterio peruano o paráfrasis de los ciento cincuenta salmos de David. Lima: Imprenta de Jose Masías, 1833.

Vázquez, Máximo. Estudio de la constitución peruana para los cursantes del segundo grado de instrucción media y para los ciudadanos en general. Lima: Benito Gil, 1899.

Varios. Lecciones de topografía dictadas en la escuela de ingenieros recopilación hecha por los alumnos. Lima: 1900.

Varios. Biblioteca de "El Callao" Ramillete Literario para las familias tomo i. Callao: Imprenta de "El Callao" Independencia, 1890.

Vázquez, Máximo M. Estudio de la constitución peruana para los cursantes del segundo grado de instrucción media para los ciudadanos en general. Lima: Librería e Imprenta Gil Banco del Herrador, 1899. . Geografía General. Lima: 1876, 1889.

Velada Literaria en el general de San Carlos : homenaje alumnos que sucumbieron en la guerra con Chile. Lima: Ip. De Torres Aguirre Mercaderes, 1890.

Verjel, Juan C. Lecciones intuitivas de Geografía sobre el mapamundi. Lima: Librería Francesa Científica Galland, 1889.

Villareal, Federico. Método Grafico Geografía del Perú para la Enseñanza Primaria. Lima: Librería Francesa Científica, 1892.

Voto Bernales, Enrique. El Calculador Practico o Manual de escritorio para uso del comercio conteniendo tablas para la cubicación de cualquiera solido

Whilar, A. T. Curso teórico-práctico de gramática castellana según el novísimo método seguido por los más notables gramáticos alemanes, franceses, ingleses y norteamericanos. Lima: Benito Gil, 1888. 
Zalazar, Manuel M. Compendio de la vida de Nuestro señor Jesucristo para las escuelas de Instrucción primaria. Lima: Imp. Del Estado, 1871.

\section{SECONDARY SOURCES}

Acree, William. Everyday Reading: Print Culture and Collective Identity in the Rio de la Plata 1870-1910. Vanderbilt University Press, 2011.

Alaperrine-Bouyer, Monique. La educación de las elites indígenas en el Perú colonial. Instituto Frances de Estudios Andinos, 2007.

Anderson, Benedict R. O'G. Imagined Communities: Reflections on the Origin and Spread of Nationalism. London: Verso, 1983.

Arnold, Denise. The Metamorphosis of Heads: Textual Struggles, Education and Land in the Andes. University of Pittsburg, 2006.

Basadre, Jorge. Historia de la República del Perú, 1822-1933. Lima: Editorial Universitaria, 1968.

Bonilla, Heraclio. "The War of the Pacific and the National and Colonial Problem in Peru." Past \& Present, No. 81 (Nov 1978): 92-118.

Britton, John A. Molding the Hearts and Minds: Education, Communications and Social Change in Latin America. Jaguar Books, 1994.

Burns, Kathryn. Colonial Habits: Convents and the Spiritual Economy of Cuzco, Peru. Durham, NC: Duke University Press, 1999.

Calogero, Steve. "Why Positivism Failed in Latin America" in Latin American Positivism: New Historical and Philosophic Essays, edited by Gregory D. Gilson and Irving W. Levinson. New York: Lexington Books, 2013.

Castro-Klarén, Sara, and John Charles Chasteen. Beyond Imagined Communities: Reading and Writing the Nation in Nineteenth-Century Latin America. Washington, D.C.: Woodrow Wilson Center Press, 2003.

Centeno, Miguel A. and Agustin E. Ferraro. State and Nation Making in Latin America and Spain. Cambridge University Press, 2013.

Chambers, Sarah. From Subjects to Citizens: Honor, Gender and Politics in Arequipa, Peru, 1780-1854. University Park: Pennsylvania State University Press, 1999. 
Chavarría, Jesús. "The Intellectuals and the Crisis of Modern Peruvian Nationalism: 18701919.” The Hispanic American Historical Review, Vol. 50, No. 2 (May, 1970): 257278.

Coronado, Jorge. The Andes Imagined: Indigenismo, Society, and Modernity. Pittsburgh, Pa: University of Pittsburgh Press, 2009.

Coultrap-McQuin, Susan Margaret. Doing Literary Business: American Women Writers in the Nineteenth Century. Chapel Hill: University of North Carolina Press, 1990.

Davies, Catherine, Claire Brewster, and Hilary Owen. South American independence: gender, politics, text. Liverpool: Liverpool University Press, 2006.

Denegri, Francesca. El Abanico y la Cigarrera: La primera generación de mujeres ilustradas en el Perú. Lima: 1860-1895.

Earle, Rebecca. "Information and Disinformation in Late Colonial New Granada." The Americas, Vol. 54, No. 2 (Oct., 1997): 167-184.

. "The Role of Print in the Spanish-American Wars of Independence." In The Political Power of the Word, edited by Ivan Jaksic, 9-33. London: University of London/Institute of Latin American Studies, 2002.

Espinoza, Antonio. Education and the State in Modern Peru: Primary Schooling in Lima, 1821-c. 1921. Palgrave Macmillan, 2013.

Ferreira, Leonardo. Centuries of Silence: The Story of Latin American Journalism. Westport, CT: Praeger, 2006.

Gootenberg, Paul, Imagining Development: Economic Ideas in Peru's "Fictitious Prosperity" of Guano, 1840-1880. Berkeley: University of California Press, 1993.

Greenberg, Janet. "Toward a History of Women's Periodicals." In Women, Culture and Politics in Latin America, edited by Seminar on Feminism and culture in Latin America. Berkeley: University of California Press, 1990.

Guy, Donna. Women Build the Welfare State: Performing Charity and Creating Rights in Argentina, 1880-1955. Durham: Duke University Press, 2009.

Habermas, Jurgen. The Structural Transformation of the Public Sphere: An Inquiry into a Category of Bourgeois Society. The MIT Press, 1991.

Hanson, Mark. Educational Reform and Administrative Development: the Cases of Colombia and Venezuela. Hoover Institution Press, 1986. 
Hart, Stephan M. A Companion to Spanish-American Literature. London: Tamesis Books, 1999.

Infante Vargas, Lucrecia. "De la escritura a la redacción de revistas femeninas. Mujeres y cultura escrita en México durante el siglo XIX.” Relaciones 113, (Invierno 2008).

Lavrín, Asunción. Women, Feminism, and Social Change in Argentina, Chile, and Uruguay, 1890-1940. London: University of Nebraska, Press, 1995.

Mallon, Florencia E. Peasant and Nation: The Making of Postcolonial Mexico and Peru. Berkeley: University of California Press, 1995

Mannarelli, María Emma. Limpias y modernas: género, higiene y cultura en la Lima del novecientos. Lima: Ediciones Flora Tristán, 1999.

Mariátegui, José Carlos. Seven Interpretative Essays on Peruvian Reality (1928). Austin, TX: University of Texas Press, 1971.

Martin, Leona S. "Nation Building, International Travel, and the Construction of the Nineteenth-Century Pan-Hispanic Women's Network." Hispania, Vol. 87, No. 3 (Sep., 2004): 439-446 Http://www.jstor.org/stable/20063026.

Martínez Boom, Alberto and José M. L. Bustamante Vismara. Escuela pública y maestro en America Latina. Buenos Aires: Universidad Pedagogica Nacional 2014.

Martínez Muñoz, Milagros. Cáceres: el gobierno de reconstrucción nacional y el golpe de estado de 1895. Breña: Orden de la legion Mariscal Cáceres, 2009.

Masiello, Francine. Between Civilization and Barbarism: Women, Nation, and Literary Culture in Modern Argentina. Lincoln \& London: University of Nebraska Press, 1992.

Milanich, Nara B. Children of Fate: Childhood, Class, and the State in Chile, 1850-1930. Durham: Duke University Press, 2009

Mora García, José Pascual. La dama, el cura y el maestro en el siglo XIX: (la historia social de la educación y de las mentalidades en la vicaría foránea de La Grita y región andina venezolana). Mérida, Venezuela: Universidad de Los Andes, 2004.

Moral, Solsiree del. Negotiating Empire: The Cultural Politics of Schools in Puerto Rico, 1898-1952. Madison: The University of Wisconsin Press, 2013. 
Morán Ramos, Luis Daniel, María Isabel Aguirre Bello, and Waldemar Espinoza Soriano. Sociedad colonial y vida cotidiana en Lima a través de las páginas de El Investigador [del Perú], 1813-1814. Lima, Perú: [s.n.], 2007.

Morcillo, Aurora. True Catholic Womanhood: Gender Ideology in Franco's Spain. DeKalb: Northern Illinois University Press, 2000.

Pericles Trifonas, Peter. Revolutionary Pedagogies: Cultural Politics, Instituting Education, and the Discourse of Theory. Routledge, 2000.

Popkewitz, Thomas S. Rethinking the History of Education: Transnational Perspectives on its Questions, Methods, and Knowledge. Palgrave Macmillan, 2013.

Popkewitz, Thomas S., Barry M. Franklin and Miguel A. Pereyra. Cultural History and Education. Routledge, 2001.

Premo, Bianca.Children of the Father King: Youth, Authority, \& Legal Minority in Colonial Lima. Chapel Hill, NC: University of North Carolina Press, 2005.

Rama, Angel. The Lettered City. Durham and London: Duke University Press, 1996.

Sábato, Hilda. "On Political Citizenship in Nineteenth-Century Latin America." The American Historical Review, Vol. 106, No. 4 (Oct., 2001): 1290-1315.

. The Many and the Few: Political Participation in Republican Buenos Aires. Stanford: Stanford University Press, 2001.

Skuban,William. Lines in the Sand: Nationalism and Identity on the Peruvian-Chilean Frontier. Albuquerque: University of New Mexico Press, 2007.

Sommer, Doris. Foundational Fictions: The National Romances of Latin America. Berkeley: University of California Press, 1991.

Uribe-Uran, Victor. "The Birth of a Public Sphere in Latin America during the Age of Revolution."

Comparative Studies in Society and History, Vol. 42, No. 2 (Apr., 2000): 425-457.

. State and Society in Spanish America During the Age of Revolution. Wilmington, Del: SR Books, 2001.

Varillas Montenegro, Alberto. El periodismo en la historia del Perú. Lima: Universidad San Martin de Porres, 2008. 
Vaughan, Mary K. The State, Education, and Social Class in Mexico, 1880-1928. DeKalb: Northern Illinois University Press, 1982.

Whipple, Pablo. La gente decente de Lima. 
VITA

\section{GRACIA SOLIS}

Born in Tucson, AZ

2002-2007

B.A. in History

Arizona State University

Tempe, AZ

2010-2017

Graduate Teaching Assistant

Florida International University

Miami, FL

2010-2012

M.A. in History

Florida International University

Miami, FL

2014

Tinker Field Research Grant

Latin American and Caribbean Center

Miami, Florida

2015

Morris and Anita Broad Research Fellowship

School of International and Public Affairs

Florida International University

2016

The History Project Research Award

Joint Centre for History and Economics

Harvard University

2016

Dissertation Evidence Acquisition Fellowship

Florida International University

Spring 2016

2017

Dissertation Year Fellowship

Florida International University

Miami, FL

\section{PUBLICATIONS AND PRESENTATIONS}

"Filibustering, Honor and the Print Media: The 1844 Sentmanat Expedition to Tabasco, Mexico." The Atlantic Millennium (2013): 47-63. 
Book review of Las mujeres y sus propuestas educativas, 1870-1930 by Maria Mannarelli” in Boletin del Instituto Riva-Agüero (Summer 2016): 235-39.

Book review of The Vanguard of the Atlantic World: Creating Modernity, Nation, and Democracy in Nineteenth-Century Latin America by James Sanders in The Atlantic Millennium, Vol. 14 (2015-16): 49-50.

"Literatas, Education and Secularization in Peru", Paper accepted at the Latin American Studies Association (LASA) 2016 Conference, New York, NY, May 2016.

"Manuals, Writers and Bookstores: Popular Didacticism in Peru, 1870-1900" Paper presented at the Southern Conference on Latin American Studies (SECOLAS), March 2016. University of Cartagena.

"Estudios de Historia Latinoamericana en el Contexto del Mundo Atlántico" Joint Conference with Judith Mansilla at the Universidad de Cartagena, Cartagena, Colombia, March 2016.

"Mujeres escritoras, el periodismo aficionado y la didáctica popular en Perú y Colombia durante la segunda mitad del siglo XIX." Paper presented at the conference, "Investigando la historia del Perú colonial y republicano en el contexto del mundo Atlántico,” Pontificia Universidad Católica del Perú, Lima, 2015.

"Filibustering, Honor and the Print Media in the Caribbean during the mid-Nineteenthcentury." Paper at the Department of History Graduate Student Association Conference, "Recent Transdisciplinary Approaches to the Atlantic World," Miami, Florida, 2012. 